\title{
MAGMATISMO E EVOLUÇÃO METAMÓRFICA DO COMPLEXO ANÁPOLIS-ITAUÇU NA REGIÃO DE DAMOLÂNDIA, GOIAS.
}

Dissertação de Mestrado N $^{\circ} 371$

Stephanie Karen Ward Maia

Brasília, setembro de 2016 

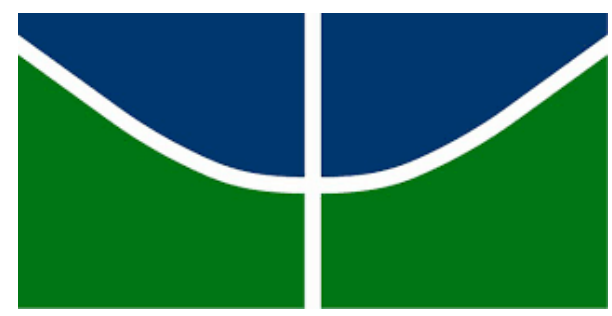

UNIVERSIDADE DE BRASÍLIA INSTITUTO DE GEOCIÊNCIAS

\section{MAGMATISMO E EVOLUÇÃO METAMÓRFICA DO COMPLEXO ANÁPOLIS-ITAUÇU NA REGIÃO DE DAMOLÂNDIA, GO}

Stephanie Karen Ward Maia

Dissertação de Mestrado $N^{\circ} 371$

Orientadora: Prof ${ }^{\mathrm{a}}$. Dra. Maria Emilia Schutesky Della Giustina (IG - UnB)

Examinadores:

Prof ${ }^{\mathrm{a}}$. Dra. Maria Emilia Schutesky Della Giustina IG-UnB (orientadora)

Prof. Dr. Reinhardt Adolfo Fuck IG-UnB (membro interno)

Prof. Dr. Renato de Moraes IG-USP (membro externo)

Prof. Dr. Elton Luiz Dantas IG-UnB (membro interno - suplente) 


\section{AGRADECIMENTOS}

Aos meus pais, Jacqueline e Milton, por me apoiarem incondicionalmente e por, além de revisarem o texto final, terem me auxiliado na jornada acadêmica até agora.

Ao meu poodle Moty, companheiro constante dos últimos 15 anos e minha motivação para acordar cedo de manhã, sair da frente do computador e ir para o mundo real.

Aos colegas de mestrado, Gabriel Franco, Felipe Ruiz, Hammel Macedo e Karen Silva, por terem sido fonte constante de apoio e ajuda nos estudos.

À professora Dr(a). Maria Emília Schutesky Della Giutina, por toda a dedicação e disponibilidade na transmissão do conhecimento.

Aos professores Dr. Reinhardt Adolfo Fuck e Renato de Moraes, por terem participado da banca examinadora da presente dissertação.

Ao CNPq, IG-UnG pelo suporte e custeio nas diversas etapas de confecção da presente dissertação. 


\section{ÍNDICE}

I - Resumo......

viii

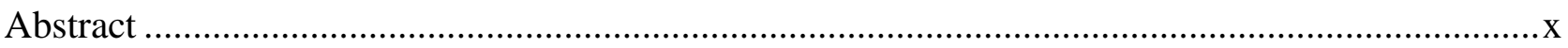

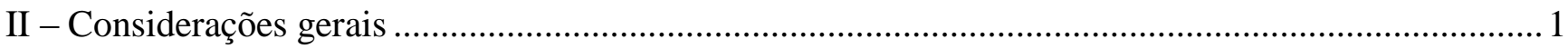

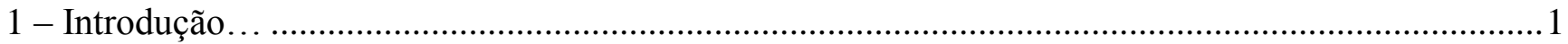

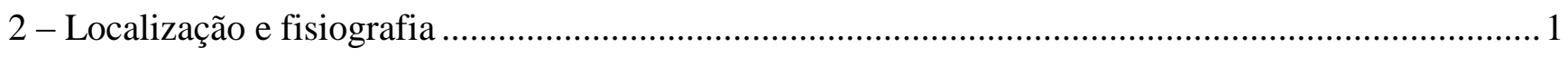

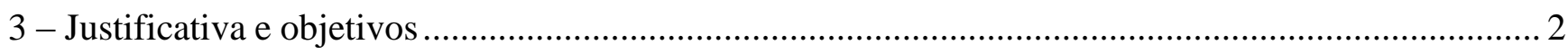

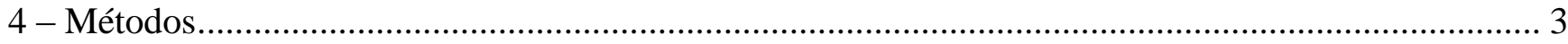

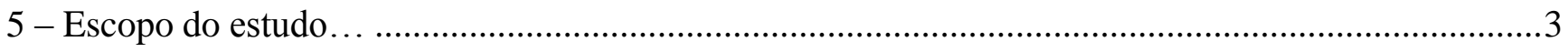

III - MAGMATISMO E EVOLUÇÃO METAMÓRFICA DO COMPLEXO ANÁPOLIS-ITAUÇU NA

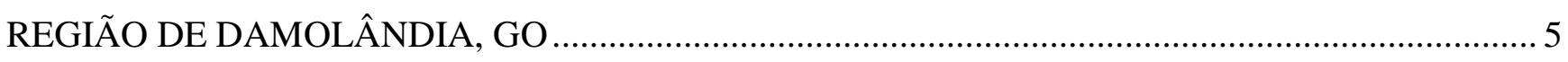

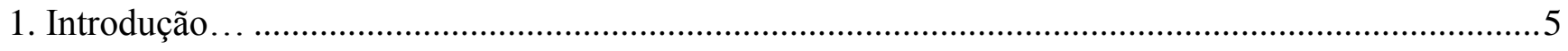

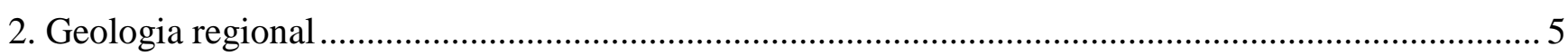

2.1. O Complexo de Damolândia - dados anteriores.................................................................... 9

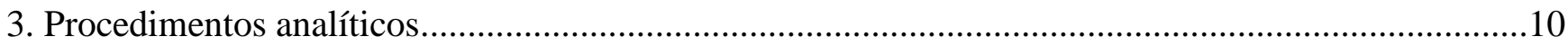

3.1. Análises de Microssonda............................................................................................. 10

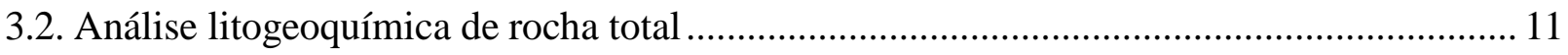

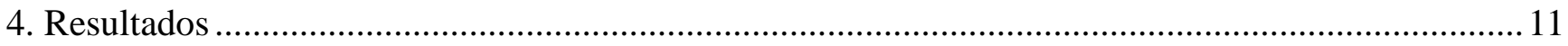

4.1. Geologia e petrologia do Complexo de Damolândia ................................................................ 11

4.1.1.Zona Ultramáfica ……………….............................................................. 12

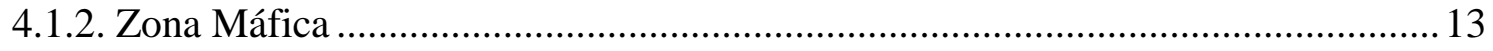

4.1.3. Granulito a Dois Piroxênios ............................................................................... 17

4.1.4. Granada-hedembergita Granulito................................................................... 17

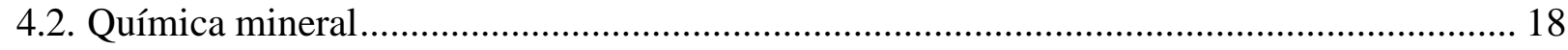

4.2.1. Óxidos e sulfetos ...................................................................................... 20

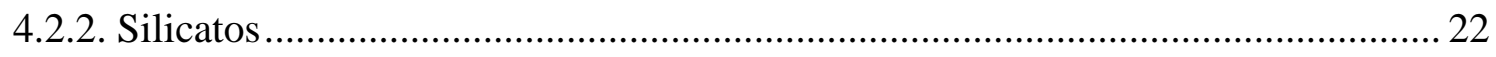

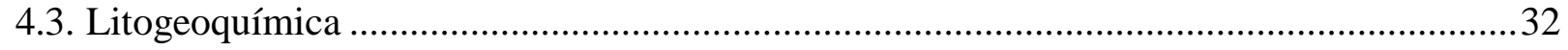

4.4. Elementos traço ................................................................................................... 36

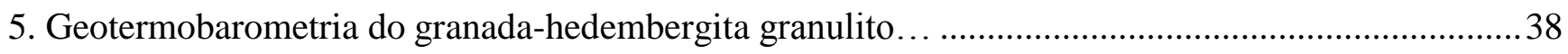

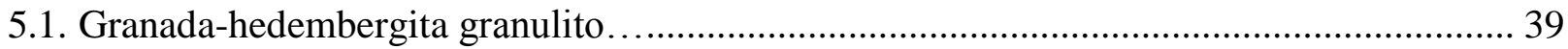

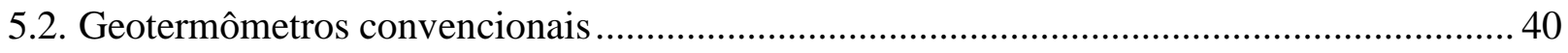

5.2.1. Grananada-clinopiroxênio................................................................................... 40 
5.2.2. Aplicação dos geotermômetros convencionais 42

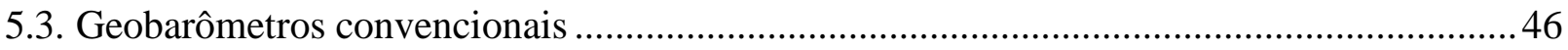

5.3.1. Granada-piroxênio-plagioclásio-quartzo... .......................................................46

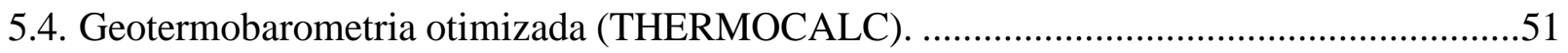

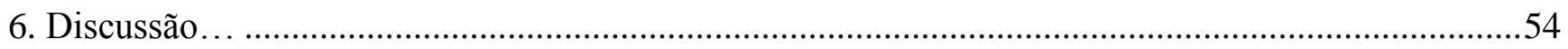

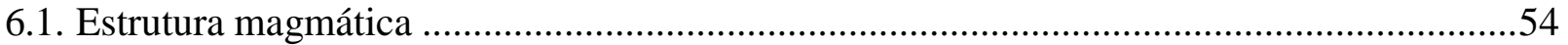

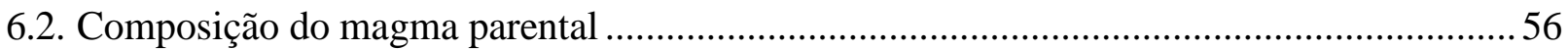

6.3. Contexto petrotectônico do Complexo de Damolândia ...................................................57

6.4. Metamorfismo das rochas magmáticas do Complexo de Damolândia .............................59

6.5. Implicações para a evolução da Faixa Brasília ............................................................... 61

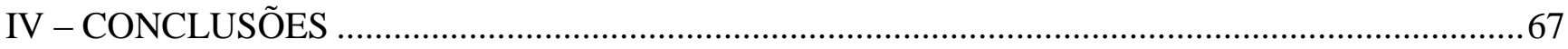

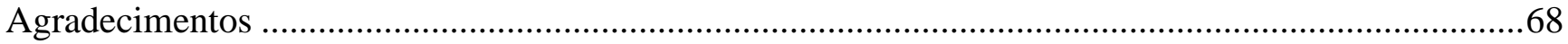

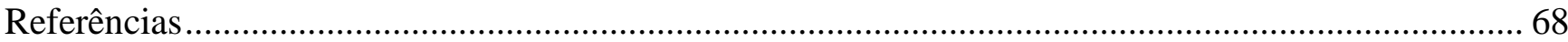

ANEXOS

Anexo I - Resultados de química mineral (análises de microssonda) - olvina (ol), ortopiroxênio (opx), clinopiroxênio (cpx), plagioclásio (plg), granada (grt), biotita (bt), hialofana (hy), pirrotita (po), pentlandita (pn), pirita (py), calcopirita (calc), cromita (chr) e ilmenita (ilm) do Complexo MáficoUltamáfico Acamadado de Damolândia 


\section{ÍNDICE DE FIGURAS}

Figura 1: Mapa simplificado da localização da área de estudo com as principais vias de acesso... 2 Figura 2: a) Mapa regional simplificado da Faixa Brasília, na porção leste da Província Tocantins (modificado de Della Giustin et al, 2009a); e b) mapa geológico da porção central do Complexo Anápolis-Itauçu com ênfase para a área de estudo (modificado de Piuzana et al, 2003a). .8

Figura 3: Geologia do Complexo de Damolândia (de um trabalho não publicado pela International Nickel Venture Ltd., retirado de Della Giustina, 2010).

Figura 4: a) Harzburgito da Zona Ultramáfica do furo de sondagem FSDM07; b) fotomicrografia do harzburgito com olivina cumulática inclusa oikocrist de ortopiroxênio; c) norito da Zona Máfica de Base do furo de sondagem FSDM07; d) fotomicrografia do norito com grãos reliquiar de clinopiroxênio cumulático e plagioclásio; e) gabronorito tardio da Zona Máfica de Topo do furo de sondagem FSDM07; f) fotomicrografia do gabronorito tardio evidenciando a granulação fina e foliação pervasiva marcada pelos filossilicatos e anfibólios; g) piroxenito trasicional entre a Zona Ultramáfica e Máfica do furo de sondagem FSDM07 evidenciando o xenólito que ocorre nessa porção; h) fotomicrografia do xenólito evidenciando a mineralogia exótica às demais rochas do complexo, com hialofana e cianita, possivelmente como produtos de metassomatismo.

Figura 5: i) Piroxenito de transição entre a Zona Ultramáfica e Máfica onde os sulfetos disseminados são mais abundantes (do furo de sondagem FSDM07); j) foto da sessão polida do piroxenito evidenciando os grãos de pirrotita, que compõem a fase sulfetada predominante, de granulação media a grossa com inclusões de calcopirita e pirita e exsoluções (flames) de pentladita; k) fotomicrografia de cromita com exsolução de titânio cumulática mais abundante na Zona Ultramáfica; 1) fotomicrografia do zircão acessório no gabronorito tardio da Zona Máfica de Topo evidenciando as duas gerações de ilmenita observadas, sendo uma inclusa no zircão e outra acompanhando a foliação; m) detalhe da ilmenita com exsolução de hematita inclusa no zircão; n) fotomicrografia do granada-hedembergita ganulito evidenciando a textura granoblástica da associação mineralógica do pico do metamorfismo granada + hedembergita + anortita; o) imagem do microscópio eletrônico de varredura evidenciando as coronas de reação entre a granada e o clinopiroxênio (hedembergita); e p) imagem do microscópio eletrônico de varredura do granada-hedembergita granulito evidenciando a intrínseca relação entre a granada e o clinopiroxênio. 16

Figura 6: Comparação dos teores de Mg\#, Fo (\%), En (\%) e An (\%) calculados com base em dados de microssonda eletrônica para as fases minerais e $\mathrm{Ni}(\mathrm{ppm}), \mathrm{Na}_{2} \mathrm{O}+\mathrm{K}_{2} \mathrm{O}$ (wt\%), $\mathrm{La} / \mathrm{Yb}(\mathrm{ppm}), \mathrm{Gd} / \mathrm{Yb}$ 
(ppm) e S (\%) calculados com base nos dados de rocha total, versus a estratigrafia do Complexo de Damolândia proposta por Della Giustina et al (2011a). ZU = Zona Ultramáfica, ZMB = Zona Máfica de Base e ZMT = Zona Máfica de Topo. 18

Figura 7: Variação dos teores de Fo (\%) versus os teores de Ni (ppm) para as rochas do Complexo de Damolândia. A linha pontilhada representa o trend composicional para a olivina de complexos acamadados (Simkin and Smith, 1970).

Figura 8: Perfil composicional de olivina reliquiar de um harzburgito da Zona Ultramáfica do Complexo de Damolândia..... 23

Figura 9: Gráfico do $\mathrm{MgO}(\mathrm{wt} \%)$ versus os teores de Fo (\%) das rochas ultramáficas e máficas do Complexo de Damolândia.....

Figura 10: Gráfico de caracterização de ortopiroxênio do Complexo de Damolândia e do granulito regional. Os círculos pontilhados separam o ortopiroxênio das porções preservadas e das porções recristalizadas, tanto para as rochas da Zona Máfica quanto Ultramáfica

Figura 11: Perfis composicionais de ortopiroxênio do Complexo de Damolândia a) piroxenito; b) harzburgito e c) granulito regional .... 25

Figura 12: a) Gráfico de variação dos teores de $\mathrm{MgO}$ (wt\%) versus $\mathrm{FeO}$ (wt\%) para as rochas do Complexo de Damolândia e; b) variação dos teores de En (\%) versus $\mathrm{FeO}$ (wt\%). Os gráficos evidenciam a variação desses teores tanto para as porções preservadas quanto para as recristalizadas.

Figura 13: Perfis composicionais de clinopiroxênio do Complexo de Damolândia a) piroxenito e b) granulito regional 26

Figura 14: Figura 14: a) gráfico de caracterização de clinopiroxênio das rochas do Complexo de Damolândia e do granulito regional; b) gráfico de caracterização de clinopiroxênio do granadahedembergita granulito.

Figura 15: a) Gráfico dos valores de $\mathrm{Al}_{2} \mathrm{O}_{3}$ (wt\%) versus $\mathrm{CaO}$ (wt\%); e b) En (\%) versus $\mathrm{CaO}$ (wt\%) evidenciando a diferença desses valores entre as porções preservadas e as recristalizadas para o granulito regional, o granada-hedembergita granulito e as rochas do Complexo de Damolândia

Figura 16: a) Gráfico de caracterização de plagioclásio do granada-hedembergita granulito; e b) das rochas do Complexo de Damolândia ..... 28

Figura 17: Gráfico da variação dos teores de An (\%) versus a profundidade das rochas analisadas 28

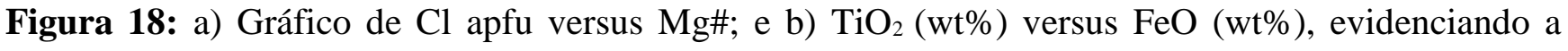
diferença entre a biotita nas rochas do Complexo de Damolândia e o granulito regional ..... 29

Figura 19: Gráfico de caracterização de hialofana e das trocas catiônicas observadas nesses minerais. 
Os Campos cinza no triângulo composicional são estimativas da quantidade de solução sólida nos feldspatos em diferentes fácies metamórficas, sendo os limites cinza-escuros referentes a fácies anfibolito inferior à intermediário e a cinza-claro referente a fácies anfibolito superior a granulito (retirado dos limites apresentados em Essene et al (2005))...

Figura 20: Perfil composicional de granada do granada-hedembergita granulito (amostra DM19) analisado.

Figura 21: Gráfico dos teores da molécula de grossulária (\%) versus as moléculas de almandina e andradita $(\%)$

Figura 22: Gráficos de $\mathrm{MgO}$ versus o conteúdo dos elementos maiores para as rochas do Complexo de Damolândia. Os dados aqui apresentados foram retirados das análises geoquímicas de rocha total apresentados na tabela 1. Os campos utilizados para as delimitação das fases cumuláticas predominantes e das tie-lines foram confeccionadas a partir de uma média dos valores para os respectivos minerais observados no Complexo de Damolândia

Figura 23: $\mathrm{MgO}$ versus o conteúdo dos elementos menores e gráficos de $\mathrm{Al}_{2} \mathrm{O}_{3}-\mathrm{CaO}$ para as rochas do Complexo de Damolândia.Os campos utilizados para as delimitação das fases cumuláticas predominantes e das tie-lines foram confeccionadas a partir de uma média dos valores para os respectivos minerais observados no Complexo de Damolândia 35

Figura 24: a) Perfis de elementos terras-rara (REE) das rochas máficas Complexo de Damolândia normalizados pelo condrito; b) rochas ultramáficas; c) granulito regional. Os valores foram comparados aos de Americano do Brasil (Mota e Silva, 2009; Mota e Silva et al., 2011). Os dados foram normalizados a partir da tabela 1. Os valores padrões dos condritos normalizados foram retirados de Sun and McDonough (1989). 36

Figura 25: a) Perfis de alteração dos elementos traço normalizados pelo manto primitivo das amostras das rochas máficas do Complexo de Damolândia; b) rochas ultramáficas; c) granulito regional. Os valores foram comparados aos do Complexo Americano do Brasil (Mota e Silva, 2009; Mota e Silva et al., 2011). Os dados foram normalizados a partir da tabela 1 e os valores de normalização do manto primitivo são de Sun and McDonough (1989). 37

Figura 26: a) Teores da fração molar de $\mathrm{Ca}\left(\mathrm{X}_{\mathrm{ca}}\right)$ das granada versus as temperatura $\left({ }^{\circ} \mathrm{C}\right)$ obtidas com o geotermômetro de Ellis \& Green (1979) e b) Ravna (2000); c) teores da fração molar de Mn (X $\left.\mathrm{X}_{\mathrm{Mn}}\right)$ da granada versus as temperaturas obtidas com o termômetro de Ravna (2000).. .45

Figura 27: a) Variação das temperaturas calculadas com os termômetros de Ellis \& Green (1979); e b) Ravna (2000), ao longo do perfil composicional da granada .46

Figura 28: Gráfico do cálculo das pressões por meio das curvas de logK (modificado de Essene, 1989) 
Figura 29: a) Variação das pressões calculadas com o barômetro de Moecher et al (1988) para as temperaturas de Ellis \& Green (1979); e b) Ravna (2000).

Figura 30: a) Variação das temperaturas e pressões calculadas com o geobarômetro de Moecher et al (1988) e o termômetro de Ellis \& Green (1979) e b) Ravna (2000). 50

Figura 31: Teores de $\mathrm{X}_{\mathrm{Ca}}$ das granada versus as pressões calculadas com o geobarômetro HD de Moecher et al (1988) para as pressões de Ellis \& Green (1979) e b) Ravna (2000).

Figura 32: a) Valores de pressão $(\mathrm{P})$ versus temperatura $(\mathrm{T})$ para ao dados obtidos com o software THERMOCALC no modo avPT; e b) avP e avT. 53

Figura 33: a) Variação das pressões no modo avP com o software THERMOCALC; e b) variação das temperaturas calculadas no modo avT com o software THERMOCALC... 53

Figura 34: Comparação entre a) perfil composicional da granada do granulito UHT versus b) variação das temperaturas calculadas com o THERMOCALC pelo método avT $\left({ }^{\circ} \mathrm{C}\right)$.

Figura 35: Gráfico das razões de $\mathrm{Ta} / \mathrm{Yb}$ versus $\mathrm{Th} / \mathrm{Yb}$ evidenciando a variação nas assinaturas das rochas do Complexo de Damolândia e o granulito regional analisado... 59

Figura 36: Variações das datações de U-Pb para as rochas do $\mathrm{CD}$ e os granulitos máficos regionais (gráfico confeccionado com os dados publicados por Della Giustia et al, 2012)...

Figura 37: Gráfico de variação dos valores de $\mathrm{Hf}$ observados para as rochas do $\mathrm{CD}$ e para os granulitos máficos regionais descritos no presente trabalho (gráfico confeccionado com os dados publicados por Della Giustina et al, 2012). 64

Figura 38: Resumo das idades e temperaturas registradas no Complexo Anápolis-Itauçu e no Complexo de Damolândia. 1 - o presente trabalho; 2 - Moraes et al (2002); 3 - Della Giustina et al (2012); 4 - Moraes (2013); 5 - Miranda et al (2015);6 - Piuzana et al (2002); 7 - Mota e Silva et al (2011); 8 - Della Giustina et al (em preparação); 9 -Macedo (2016)... 66

\section{ÍNDICE DE TABELAS}

Tabela 1: Análises de rocha total do Complexo de Damolândia. $\mathrm{Gbr}=$ gabro, Nrt $=$ norito, Opxt $=$ ortopiroxenito, $\mathrm{Hzb}=$ harzburgito, Gbrnrt = gabronorito e $\mathrm{GR}=$ granulito regional 33

Tabela 2: Dados experimentais de sistemas químicos naturais e sintéticos com grt-cpx coexistentes utilizados na calibração do termômetro de Ravna (2000) (retirado de Ravna (2000)). 43

Tabela 3: Valores das temperaturas obtidos para os geotermômetros convencionais de Ellis \& Green 
(1979) e Ravna (2000) em pressões de 9, 10 e 11 kbar (Baldwin et al, 2005; Moraes et al, 2002)...

Tabela 4: Valores de pressões calculadas com o geobarômetro de Essene (1989) com as temperaturas calculadas com o geotermômetro de Ellis \& Green (1979) e Ravna (2000), respectivamente...............50

Tabela 5: Cálculo das pressões e temperaturas da rocha UHT por meio dos métodos avP, avT e avPT

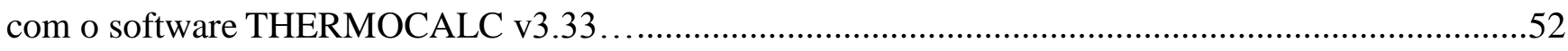

Tabela 6: Resumo das fases minerais observadas no Complexo de Damolândia, no granulito regional e no granada-hedembergita granulito nas porções ígneas preservadas, nas porções recristalizadas e no xenólito que apresenta evidências metassomáticas. $\mathrm{CD}=$ Complexo de Damolândia e GR = granulito regional. 61

Tabela 7: Valores dos isótopos de O verificados no gabronorito tardio (DM 16) e no granulito regional (DM 20) (Della Giustina et al, 2012). 63

Tabela 8: Resumo das associações minerais UHT descritas por Moraes et al (2002), Baldwin et al (2005) e no presente trabalho e condições P-T calculadas para as respectivas associações 


\section{I - RESUMO}

O Complexo de Damolândia (CD) está inserido no contexto geológico do extensivo magmatismo máfico-ultramáfico observado no Complexo Anápolis-Itauçu (CAI). O CD já foi anteriormente descrito e o presente trabalho tem como objetivo principal a descrição e caracterização ígnea e metamórfica detalhada do $\mathrm{CD}$. O CD ocorre como um corpo máfico-ultramáfico acamadado pobremente exposto, com cerca de $15 \mathrm{~km}^{2}$ e trend EW. Amostras obtidas em furo de sondagem (FSDM07) revelam tanto textura quanto mineralogia ígnea primária preservadas no $\mathrm{CD}$ e metamorfismo heterogêneo superimposto, mais evidente nos protólitos máficos. A estratigrafia do CD consiste na Zona Ultramáfica ocupando posição central encapsulada pela Zona Máfica de Base e de Topo. As rochas ultramáficas são compostas predominantemente por intercalação de olivina ortopiroxenito (cumulatos de $\mathrm{Ol}+\mathrm{Opx}$ ), ortopiroxenito (cumulatos de $\mathrm{Opx}+\mathrm{Cpx}+\mathrm{Ol}$ ) e harzburgito (cumulatos de $\mathrm{Ol}+\mathrm{Chr} \pm \mathrm{Opx}$ ). As rochas máficas são compostas principalmente por gabro (cumulatos de Opx + Cpx e Plg intresticial), norito (cumulatos de Opx \pm Cpx e Plg intersticial) e gabronorito tardio $(\mathrm{Opx}+\mathrm{Cpx}+\mathrm{Bt}+\mathrm{Plg}$ granoblásticos). $\mathrm{O}$ gabronorito tardio representa a rocha mais fracionada do $\mathrm{CD}$ no qual o metamorfismo superimposto do $\mathrm{CD}$ é mais evidente e contém ilmenita e zircão como importantes fases acessórias. Sulfetos disseminados são observados ao longo de todo o CD, tanto nas porções com as texturas e mineralogias ígneas primárias preservadas quanto nas porções recristalizadas e apresentam mineralogia consistente com cristalização a partir de solução sólida sulfetada homogênea (Monosulfide Solid Solution - MSS) típica. A principal fase sulfetada é pirrotita e de maneira secundária calcopirita e pirita, ocorrendo principalmente como inclusões e pentlandita como exsoluções em pirrotita. Poucos grãos isolados de calcopirita e pirita são observados, normalmente anédricos e nas porções recristalizadas, enquanto que pentlandita ocorre exclusivamente como exsoluções (flames) em pirrotita, não tendo sido observados grãos bem formados. A pirita é interpretada como sendo produto da recristalização, já que não é fase sulfetada comum à mineralogia MSS típica observada. Os sulfetos são mais notavelmente observados no piroxenito e norito transicional entre a Zona Ultramáfica e a Zona Máfica. Óxidos, cromita e ilmenita, também ocorrem disseminados ao longo do CD. Cromita é mais restrita ao harzburgito da Zona Ultramáfica enquanto que ilmenita é mais abundante no gabronorito tardio da Zona Máfica. Variação nos teores composicionais dos cúmulus de $\mathrm{Ol}$ nas rochas ultramáficas (Fo82-89) suporta a interpretação de magma parental primitivo para o CD. O modelamento geotermobarométrico feito para um granulito regional observado em contato com o CD revela que o metamorfismo alcançou condições de temperatura ultra-alta (UHT) pontualmente em relação ao CD, o que já havia sido descrito anteriormente para outras regiões do CAI. O granada-hedembergita granulito, descrito e modelado no presente estudo, com temperatura e pressão de $\sim 940 \quad{ }^{\circ} \mathrm{C}$ e 9,6 kbar, 
respectivamente, é interpretado como sendo resultado de metamorfismo UHT, provalvelmente em função de acréscimo de calor fornecido pela intrusão máfico-ultramáfica do magma que gerou o CD. Datações anteriores revelam idades de, $\sim 670 \mathrm{Ma}$, interpretadas como sendo referente à cristalização dessas rochas. Tais idades revelam-se mais antigas do que previamente estabelecido para a Suíte Americano do Brasil ( 630 Ma) e, consequentemente, o CD representa um episódio magmático anterior na Faixa Brasília, associado no espaço e no tempo ao metamorfismo de alto grau do CAI. 


\section{ABSTRACT}

The Damolândia Complex (DC) occurs within the geological context of the extensive mafic ultramafic magmatism observed in the Anápolis-Itauçu Complex (AIC). The DC has already been previously described and the goal of the present work is the detailed igneous and metamorphic description and characterization of the DC. The DC is as a layered mafic ultramafic poorly exposed body with aproximately $15 \mathrm{~km}^{2}$ and a EW trend. A drill hole (FSDM07) reveals that the primary igneous texture and mineralogy are preserved in the DC with a heterogeneous superimposed metamorphism, significantly more evident in the recristalized portions of the rocks and in the late gabronorite. The DC stratigraphy consists of a Ultramafic Zone in the center rocks encapculated by the Mafic Zone. The ultramafic rocks are composed predominantly by interlayered olivine orthopyroxenite $(\mathrm{Ol}+\mathrm{Opx}$ cumulates $)$, orthpyroxenite $(\mathrm{Opx}+\mathrm{Cpx}+\mathrm{Ol}$ cumulates $)$ and harzburgite $(\mathrm{Ol}+\mathrm{Chr} \pm \mathrm{Opx}$ cumulates). The mafic rocks are composed predominantly by gabro (Opx + Cpx cumulates $+\mathrm{Plg}$ intercumulates), norite (Opx + Cpx cumulates + Plg intercumulates) and late stage gabronorite (granoblastic $\mathrm{Opx}+\mathrm{Cpx}+\mathrm{Bt}+\mathrm{Plg}$ ). The late stage gabronorite represents the most fraccionated rocks in the DC where the superimposed metamorphism in the DC is more pronounced and contain ilmenite and zircon as important acessory phases. Sulfides occur disseminated throughout the DC and are characterized by a typical Monosulfide Solid Solution (MSS) mineral association. The main sulfide phase observed is pirrotite with calcopirite, pentlandite and pirite ocurring mainly as exsolutions and inclusions in the pirrotite grains. Few isolated grains of calcopyrite and pyrite are observed throughout the Complex and occur generally as small rounded grains in the recrystalized portion of the rocks, while pentlandite occurs exclusively as exsolutions (flames) in pirrotites and no well formed isolated grains were observed. The pyrite is interpreted as being a product of recrystalization, since it is not a common sulfide phase observed in MSS. The sulfides are more notably observed in transitional ortopyrxenite and norite from the Ultramafic Zone to the Mafic Zone. Oxides also occur disseminated throughout the DC, more noticeably chromite and ilmenite. Chromite is more abundante in harzburgite from the Ultramafic Zone while ilmenite is more abundant in the late stage gabronorite from the Mafic Zone. Variation in the compositional values of cumulus $\mathrm{Ol}$ in the ultramafic rocks (Fo82-89) supports the interpretation of a primitive parental magma for the DC. The geothermobarometric modeling conducted for one of the regional granulites in contact with the DC reveals that the superimposed metamorphism reached ultahigh temperature (UHT) conditions in certain portions of the AIC, which has already been previously described for the AIC. The garnet-hedembergite granulite, described in the present study, yelded temperature and pressures of $\sim 940^{\circ} \mathrm{C}$ and $9,6 \mathrm{kbar}$, respectively and is interpreted as resulting from metamorphism that reached UHT conditions, probably as a result from the ascension 
of the magma that generated the DC. Ages of $\sim 670 \mathrm{Ma}$ previously published for the DC were interpreted as the cristalization age for these rocks and when it is compared to the age published for the Americano do Brasil Complex, it is possible to imagine that the DC was generated during a previous/concomitant moment to the third magmatic episode described for the Arenóplis Magmatic Arc, during the final stages of generation of the Brasília Belt. 


\section{II - CONSIDERAÇÕES GERAIS}

1 - Introdução

A presente dissertação de mestrado é resultado de pesquisas realizadas no Complexo MáficoUltamáfico Acamadado de Damolândia (CD), inserido no Complexo Anápolis-Itauçu (CAI) no Estado de Goiás. Este trabalho tem como objetivo principal contribuir com o entendimento da evolução e gênese do magmatismo máfico-ultramáfico da Faixa Brasília. Foram empregadas múltiplas ferramentas como: descrição de furo de sondagem, petrografia de detalhe, geoquímica de rocha total e análises de microssonda, tanto em silicatos quanto em sulfetos e óxidos.

A Faixa Brasília constitui um dos orógenos neoproterozóicos de maior exposição, porém vários aspectos fundamentais para o entendimento de sua evolução tectônica e, consequentemente, para a formação do Gondwana ainda permanecem desconhecidos, tanto do ponto de vista petrológico, quanto geocronológico.

Uma das principais questões pertinentes a esse orógeno reside na compreensão do volumoso magmatismo máfico neoproterozóico, revelado na forma de uma série de intrusões máfico-ultramáficas (MUM) acamadadas que se distribuem ao longo do Arco Magmático de Goiás (AMG) e no domínio do CAI e que são inseridos na Suíte Americano do Brasil, com idade de cristalização estimada em ca. 640630 Ma (Laux et al., 2004; Mota e Silva, 2009; Mota e Silva et al., 2011).

Os complexos de Damolândia, Taquaral e Goianira-Trindade representam intrusões máficoultramáficas inseridas no domínio do CAI. Trata-se de corpos acamadados de diferentes dimensões, com variado grau de superimposição do metamorfismo granulítico e que apresentam idades de cristalização mais antigas, em torno de 670 Ma (Della Giustina et al., 2011a), o que demonstra que diferentes episódios magmáticos podem ter sido responsáveis pelas intrusões máficas acamadadas observadas na Faixa Brasília (Pimentel et al., 2000; Piuzana et al, 2003a; Della Giustina et al, 2011a).

\section{2 - Localização e Fisiografia}

A área de pesquisa é composta pelo Complexo de Damolândia, localizado na porção centrooeste do Estado de Goiás, próximo às cidades de Inhumas e Damolândia e a aproximadamente $260 \mathrm{~km}$ de Brasília. As principais vias de acesso são BR060 e BR070 (figura 1). A região do complexo apresenta-se como relativamente plana, com poucos afloramentos pontilhando o cerrado. Mapeamentos anteriores conduzidos pela International Nickel Venture Ltd. foram confirmados principalmente por geoquímica de solo. 


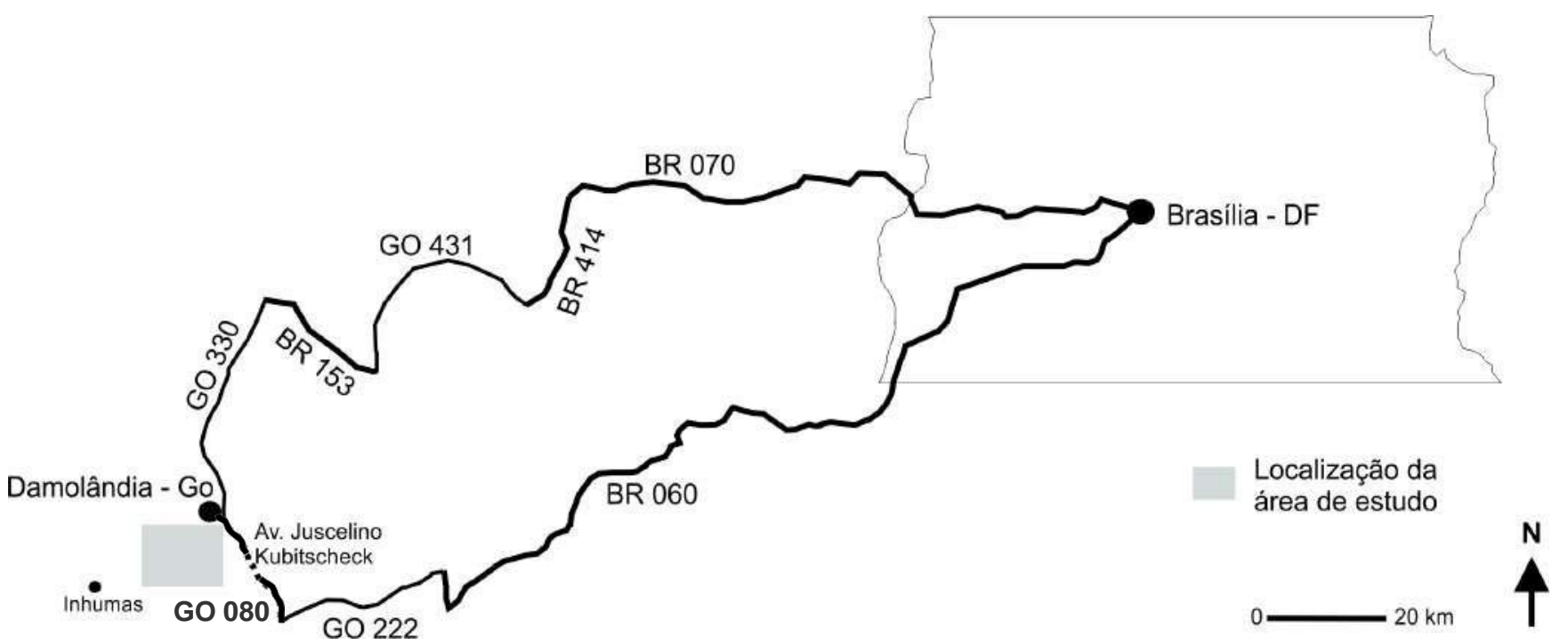

Figura 1: Mapa simplificado da localização da área de estudo com as principais vias de acesso.

\section{3 - Justificativa e Objetivos}

Esse estudo tem como objetivo apresentar e discutir informações geológicas de detalhe petrológicas, litogeoquímicas e de química mineral - que permitam a caracterização do Complexo de Damolândia no contexto do magmatismo máfico-ultramáfico da Faixa Brasília. O trabalho anterior publicado providencia essencialmente dados geocronológicos do Complexo de Damolândia (Della Giustina et al., 2011).

Porém, ainda não há no CD um estudo sistemático visando a definição da estratigrafia magmática e a caracterização de aspectos petrogenéticos e metalogenéticos associados a este corpo, bem como dos efeitosda superimposição do metamorfismo de alto grau durante o fechamento final da Faixa Brasília.

Os dados obtidos durante o desenvolvimento do projeto serão comparados às informações disponíveis na literatura para demais intrusões acamadadas da Faixa Brasília, em especial o Complexo de Americano do Brasil (CAB), datado em ca. 630 Ma (Laux et al., 2004; Mota e Silva, 2009; Mota e Silva et al., 2011). Recentes datações U-Pb em zircão nos complexos de Damolândia, Taquaral e Goianira-Trindade revelaram idades de cristalização ígnea em torno de 680-670 Ma, mais antigas do que anteriormente proposto para o magmatismo máfico-ultramáfico no domínio do Complexo Anápolis-Itauçu. Assim, o estudo petrogenético detalhado do CD permitirá discutir não somente a natureza da intrusão, mas também a hipótese de que esse corpo seja representante de episódio magmático distinto do que previamente descrito na Faixa Brasilia e um pico metamórfico mais antigo. 
Por fim, por estar inserido no CAI, o estudo do CD contribuirá também para melhor entendimento da evolução geotectônica da Faixa Brasília.

\section{4 - Métodos}

A princípio foi realizada revisão bibliográfica de artigos e teses tanto nacionais quanto internacionais. Análises detalhadas foram desenvolvidas com estudos petrográficos em lâminas delgadas/seções são de amostras do furo de sondagem, coletadas de forma a representar toda a estratigrafia magmática do CD das rochas do complexo e de suas encaixantes imediatas, o que permitiu o estudo detalhado das rochas da área de estudo. Análises de microssonda foram conduzidas em sete das dezoito lâminas e nas duas seções polidas.

A amostra DM 06B foi trabalhada no Laboratório de Laminação do Instituto de Geociências da

Universidade de Brasília (IG/UnB) a fim de confeccionar as duas seções polidas que foram então descritas, utilizando os microscópios da mesma instituição. Os sulfetos observados no CD são pirrotita, calcopirita, pentlandita e pirita. De maneira mais restrita, foram observados óxidos (cromita e ilmenita).

Análises de química de mineral utilizando microssonda eletrônica foram efetuadas no Laboratório de

Microssonda Eletrônica da Universidade de Brasília com o equipamento JEOL JXA- 8230. De forma sistemática foram analisados minerais ígneos reliquiares bem como recristalizados, dentre os quais olivina, ortopiroxênio, clinopiroxênio, plagioclásio, feldspato, sulfetos e óxidos. Os dados

foram tratados por meio tanto da planilha eletrônica Excel quanto do LibreOffice Calc e a versão integral se encontra no Anexo 1.

A preparação das amostras para análise de litogeoquímica foi realizada no moinho da Universidade de Brasília e a escolha foi feita de tal forma que a representatividade do CD fosse mantida. Oito amostras foram enviadas aos laboratórios ACME e foram analisadas pelo método convencional do laboratório para elementos maiores e menores, bem como para elementos traço.

\section{5 - Escopo do Estudo}

O trabalho de pesquisa do mestrado em questão consiste na caracterização petrológica de detalhe do Complexo de Damolândia, uma intrusão máfica-ultramáfica acamadada localizada na porção interna da Faixa Brasília. A pesquisa está inserida no Projeto Integrado de Pesquisa "Petrologia e Geocronologia de complexos máficos- ultramáficos acamadados do Arco Magmático de Goiás 
Meridional e implicações para a evolução da Faixa Brasília (Edital MCT/CNPq Universal 2014, \#455198/2014-4), coordenado pela orientadora deste mestrado, a Professora Dra. Maria Emília Schutesky Della Giustina. 


\section{III - MAGMATISMO E EVOLUÇÃO METAMÓRFICA DO COMPLEXO ANÁPOLIS- ITAUÇU NA REGIÃO DE DAMOLÂNDIA, GO}

\section{Introdução}

Estudos sistemáticos do Complexo Anápolis-Itauçu (CAI) têm demonstrado a existência de diversos complexos máfico-ultramáficos inseridos em seu contexto. Além de terrenos granulíticos terem sido submetidos a condições metamórficas extremas, alcançando metamorfismo UHT (Moraes et al, 2002; Baldwin et al, 2005). O fato de rochas que atingem o pico UHT no CAI estarem aparentemente associados ao extenso magmatismo máfico que ocorreu na região sugere que há correlação entre esses dois fenômenos.

O Complexo de Damolândia (CD) faz parte do arcabouço de complexos máfico-ultramáficos inseridos no CAI. O presente estudo tem como proposta o detalhamento desse complexo, tanto petrologicamente quanto geoquimicamente e com o modelamento de rochas UHT observados em sua proximidade. Para que tal empreitada fosse bem sucedida foram empregadas várias ferramentas, dentre as quais pode se citar descrição de furos de sondagem, petrografia, geoquímica de rocha total e extensiva e análises de microssonda. Os resultados serão apresentados em tópicos e sub tópicos individualizados dentro de quatro capítulos.

\section{Geologia Regional}

O Complexo máfico-ultramáfico acamadado de Damolândia (CD) está inserido no Complexo Anápolis-Itauçu, na porção SE da Faixa Brasília (figura 2). A Faixa Brasília é um orógeno de idade neoproterozóica, formado pela convergência de três blocos continentais no fim do Neoproterozóico: o Cráton Amazônico a oeste, o Cráton do São Francisco a leste e o Cráton Paranapanema, que se encontra atualmente recoberto pelas rochas fanerozóicas da Bacia do Paraná, localizada ao sul da Faixa Brasília (Pimentel et al., 2000; Valeriano et al., 2008). A Faixa Brasília pode ser dividida em quatro porções: (i) na porção oriental encontra-se um cinturão de dobras de sequências metassedimentares neoproterozóicas que se formaram ao longo da margem oeste do Cráton do São Francisco; o metamorfismo é progressivamente mais elevado em direção a oeste, alcançando fácies anfibolito (Campos Neto \& Caby, 2000; Dardenne, 2000; Seer et al., 2000, 2001); (ii) na porção ocidental encontra-se o arco neoproterozóico (Arco Magmático de Goiás) constituído de sequências vulcanosedimentares e gnaisses de composição tonalítica/granodiorítica (Pimentel \& Fuck 1992; Pimentel et al., 1991, 1997, 2000); (iii) na porção central da Faixa Brasília encontra-se o Complexo AnápolisItauçu, denominado o núcleo metamórfico da Faixa Brasília, composto de rochas de alto grau 
metamórfico e, pontualmente, granulitos UHT, como os descritos por Moraes et al (2002) e Baldwin et al (2005); (iv) o Maciço de Goiás, interpretado como sendo um microcontinente/terreno exótico acrescido ao orógeno no final do Neoproterozóico (Pimentel et al., 2000). As associações supracrustais na porção sul da faixa são marcadas por empurrões regionais que apresentam vergência para leste, em direção a plataforma do São Francisco-Congo (Pimentel et al., 2000, 2011).

O Arco Magmático de Goiás (AMG), na porção oeste, interpretado por vários autores (Pimentel \& Fuck, 1992; Pimentel et al., 1991, 1997; Junges et al., 2002) como sendo representante de crosta formada entre 900 e 630 Ma durante a convergência de placas. O AMG é descrito como sendo constituído por duas seções, individualizadas pelo Maciço de Goiás: Arco de Mara Rosa ao norte e Arco de Arenópolis ao sul. Dados isotópicos e geocronológicos mostram que a atividade ígnea no AMG se deu em três estágios principais (Pimentel et al., 1991; Pimentel \& Fuck, 1992; Laux et al., 2005; Pimentel, 2016): (i) entre 900 e 800 Ma, em ambiente intraoceânico composto por rochas tonalíticas da série da magnetita; (ii) entre 790 e 786 Ma, caracterizado pela geração de muscovita metagranitóides peraluminosos; e (iii) entre 660 e 600 Ma, representado pelo gnaisse metaluminoso Matrinxã, interpretado como sendo a expressão de margem continental ativa nos estágios finais de geração da Faixa Brasília. Junges et al. (2002) descrevem que as rochas do AMG foram submetidas a metamorfismo no fácies xisto verde superior a anfibolito, mas ainda retendo suas principais características geoquímicas e isotópicas.

Diversas intrusões de caráter máfico-ultramáfico ocorrem no AMG e estão inseridas na Suíte Americano do Brasil, de caráter sinorogênico, com idades variando de 630 a 600 Ma. A suíte foi definida em corpo homônimo inicialmente descrito por Metago (1978) e Nilson et al. (1986) e posteriormente detalhado por Mota e Silva (2009). O complexo de Americano do Brasil (CAB) consiste de sequência de rochas máficas e ultramáficas acamadadas, com cerca de $12 \mathrm{~km}$ de extensão e $3 \mathrm{~km}$ de largura, segundo trend EW, e subdividido em duas sequências principais: norte e sul. A sequência norte é descrita como sendo composta por rochas cumuláticas ultramáficas (dunito, wehrlito, lherzolito e websterito) e, de maneira mais restrita, rochas cumuláticas máficas (gabronorito). Nesta sequência localiza-se o corpo de minério S2, um nível concordante de sulfetos maciços a semi maciços. A sequência sul é composta por cumulatos máficos (gabronorito) com intercalação de cumulatos ultramáficos (websterito e lherzolito). Nesta porção foram mapeados os corpos de minério S1 e G2, que consistem em cluster de corpos sulfetados cilíndricos e uma sequência sulfetada concordante com a sequência sul, respectivamente. Mota e Silva (2009) e Mota et al (2011) propõem que o magma parental deste complexo apresenta afinidade toleítica e que o mesmo foi extraído de manto empobrecido em ambiente tectônico extensional durante os estágios finais de atividade do Arco 
Magmático de Arenópolis.

Em sua extremidade leste, o AMG é limitado por exposição alongada de aproximadamente 260 X 70 km de rochas de alto grau metamórfico, inseridas no Complexo Anápolis-Itauçu (CAI) (Pimentel \& Fuck, 1992; Pimentel et al., 1991, 1997; Pimentel et al., 2000; Piuzana et al., 2003a). O CAI é composto por (i) intrusões gabro-piroxeníticas; (ii) corpos de granodiorito e tonalito, ambos com texturas reliquiares parcialmente preservadas; e (iii) granulitos, representados principalmente por paragnaisses aluminosos que contém granada e sillimanita, comumente associados com formações bandadas de $\mathrm{Fe}$ e $\mathrm{Mn}$, silimanita-granada e espinélio quartzito e grossulária-escapolita-diopsídio mármore.

Estudos geocronológicos e isotópicos (Piuzana et al., 2003a, b; Hollanda et al., 2003; Laux et al., 2005) sugerem que o CAI representa complexo metamórfico originado a partir de protolitos do Grupo Araxá e do AMG metamorfizados em fácies granulito. Moraes et al. (2002) e Baldwin et al. (2005) descrevem ainda associações minerais contendo safirina e quartzo em equilíbrio, portanto compatíveis com metamorfismo de condições de temperatura ultra alta (UHT) que pode ter ultrapassado os $1000{ }^{\circ} \mathrm{C}$ e 9 kbar. Datações U-Pb em zircão destes granulitos variam de 649 a $634 \mathrm{Ma}$ (Baldwin \& Brown, 2008). Para maior detalhamento sugere-se a leitura de Moraes et al. (2002), Baldwin et al. (2005) e Baldwin \& Brown (2008).

Os complexos de Damolândia, Taquaral e Goianira-Trindade representam uma série de intrusões MUM inseridas no domínio do CAI (figura 2). Trata-se de corpos acamadados de diferentes dimensões, com variado grau de superimposição do metamorfismo granulítico. Della Giustina et al. (2011a) estudaram as ocorrências supracitadas, as quais eram anteriormente inseridas na Suíte Americano do Brasil, e revelaram idades mais antigas para este magmatismo, em torno de $670 \mathrm{Ma}$. Nessas rochas, apesar das texturas ígneas ainda permanecerem parcialmente preservadas, há intensa superimposição do metamorfismo de alto grau (especialmente no Complexo de Taquaral). Assim, este seria um episódio magmático anterior ao que havia sido previamente descrito na Faixa Brasilia. 


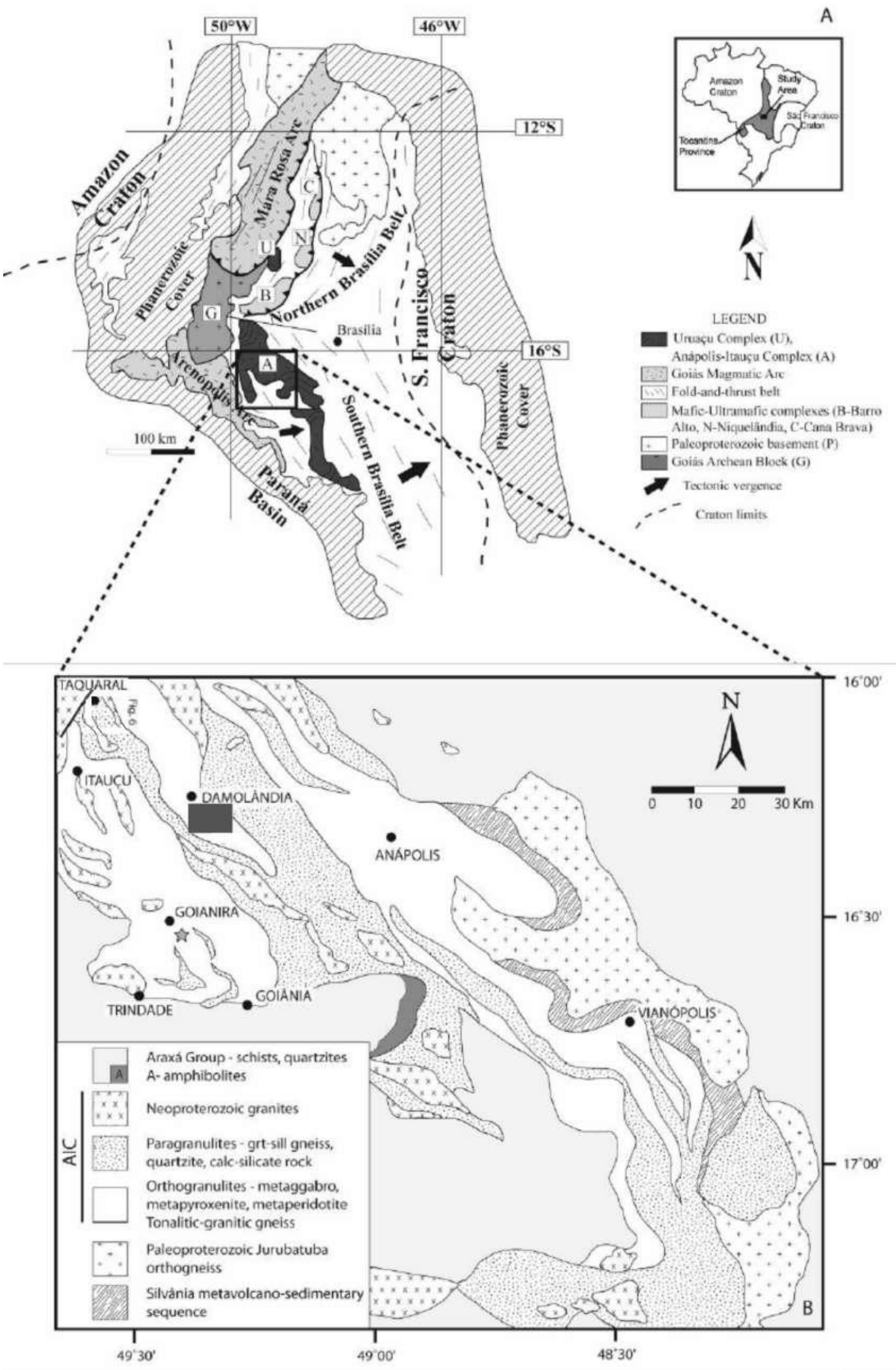

Figura 2: a) Mapa regional simplificado da Faixa Brasília, na porção leste da Província Tocantins (modificado de Della Giustina et al, 2011a); e b) Mapa geológico da porção central do Complexo Anápolis-Itauçu com ênfase para a área de estudo (modificado de Piuzana et al., 2003a). 


\subsection{Complexo de Damolândia - dados anteriores}

Estudos anteriores, como o mapeamento conduzido pela International Nickel Venture Ltd. em 2006-2008, com o objetivo de buscar alvos em potencial para exploração mineral de Ni-Cu(-PGE) na região, e o artigo publicado por Della Giustina et al. (2011a) fornecem descrições preliminares do CD. O CD é um corpo de tamanho mediano, cerca de $15 \mathrm{~km}^{2}$, encaixado em gnaisses e granulitos de alto grau do CAI e apresenta afloramentos escassos ou muito alterados. Della Giustina et al. (2011a) revelam que tanto a mineralogia quanto a textura ígnea primária do complexo se apresentam, de maneira geral, preservadas. Descrevem as rochas do complexo como sendo compostas predominantemente por domínios de peridotito-piroxenito-norito acamadados associados a domínios de rochas máficas, compostos principalmente por gabro, gabronorito e norito. As principais fases cumuláticas observadas são ortopiroxênio + plagioclásio \pm clinopiroxênio \pm hornblenda e, de maneira mais restrita, flogopita. O peridotito e piroxenito são caracterizados por apresentar olivina + ortopiroxênio \pm clinopiroxênio como fases cumuláticas e plagioclásio como principal fase intercumulus, com hornblenda e flogopita de maneira mais restrita. Com base nesses minerais, os autores propõem a seguinte sequência de cristalização para o CD

$$
\begin{gathered}
\text { olivina + cromita } \\
\text { ortopiroxênio + cromita } \\
\text { ortopiroxênio } \\
\text { ortopiroxênio + plagioclásio } \\
\text { ortopiroxênio + plagioclásio + clinopiroxênio }
\end{gathered}
$$

O metamorfismo superimposto nestas rochas pode ser verificado em porções restritas do complexo, que apresentam tanto a textura quanto a mineralogia ígnea primária parcial a completamente substituídas, gerando porções de granulação fina (Della Giustina et al., 2011a). A associação mineralógica observada nestas porções rescristalizadas, plagioclásio + ortopiroxênio + clinopiroxênio \pm anfibólio, é um indicador de que o reequilíbrio se deu em fácies granulito, como resultado de um metamorfismo regional (Della Giustina et al., 2011a).

Datação $\mathrm{U}-\mathrm{Pb}$ em zircão de gabronorito do $\mathrm{CD}$ resultou em idades concordantes que se espalham pela curva da concordia de 670 até $590 \mathrm{Ma}$, sendo a idade mais antiga interpretada como representante da cristalização ígnea concomitante ao metamorfismo de alto grau. Por outro lado, sobrecrescimento metamórfico em zircão de um granulito máfico a dois piroxênios, encaixante do complexo, revela idades similares, confirmando o caráter sin-tectônico da intrusão (Della Giustina 2010a; Della Giustina et al., 2011a). 


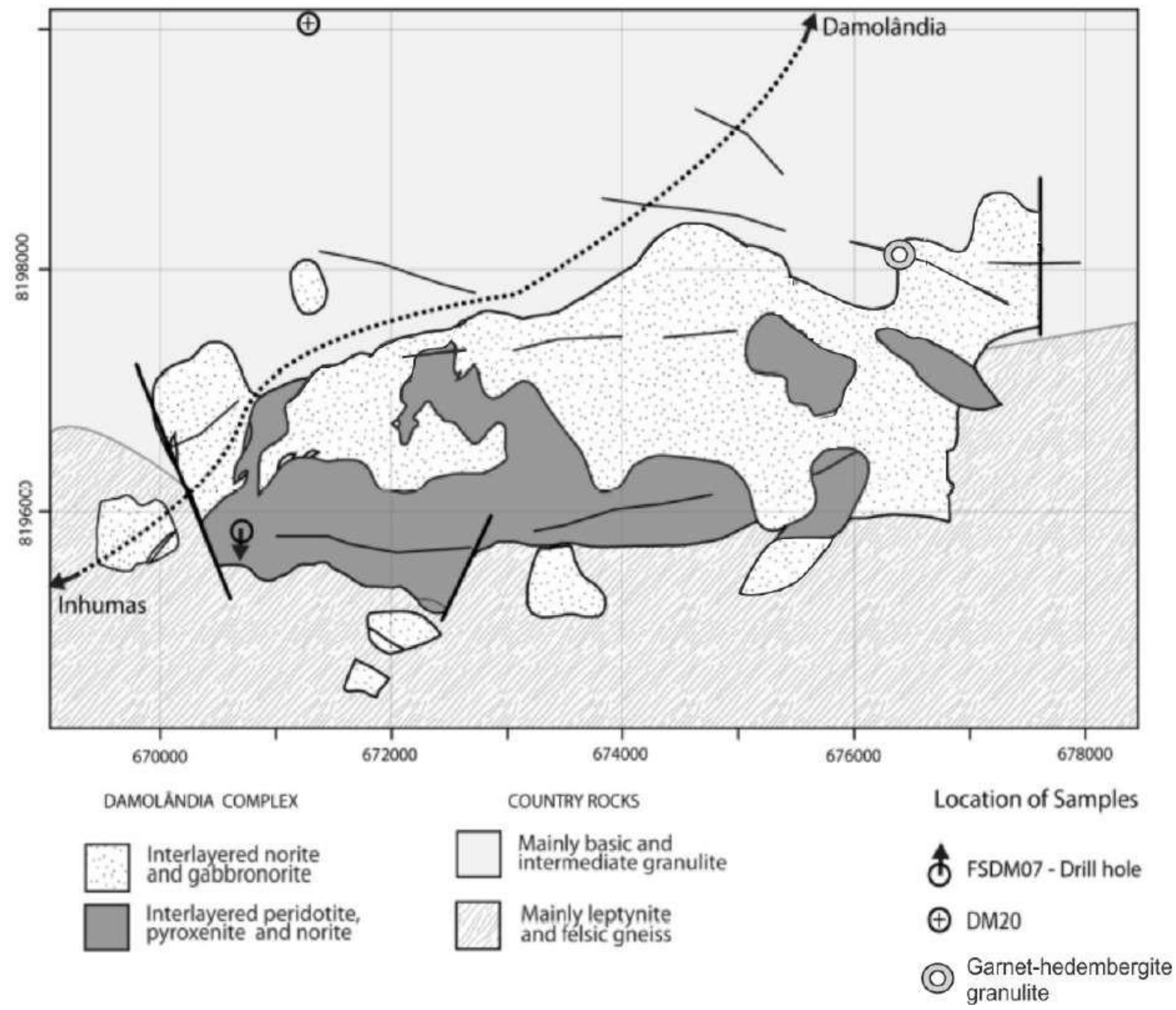

Figura 3: Geologia do Complexo de Damolândia (de um trabalho não publicado pela International Nickel Venture Ltd., modificado de Della Giustina, 2011a).

\section{Procedimentos analíticos}

\subsection{Análise de microssonda}

Análises minerais foram realizadas em lâminas delgadas polidas, usando um espectômetro-5 JEOL JXA-8230 SuperProbe no Laboratório de Microssonda Eletrônica da Universidade de Brasília (Brasil). As análises de comprimento de ondas dispersivas foram conduzidas com voltagem de aceleração de $15 \mathrm{kV}$ e corrente de $10 \mathrm{nA}$. Padrões tanto de minerais naturais quanto sintéticos foram utilizados e os mesmos procedimentos foram repetidos para todas as análises. Análises de microssonda foram feitas para olivina, ortopiroxênio, clinopiroxênio, plagioclásio, biotita, feldspato, pirrotita, calcopirita, pirita, pentlandita, ilmenita e cromita.

Por apresentar tanto texturas ígneas preservadas quanto recristalizadas, foram selecionados cristais de ambos os grupos representativos, tanto cumuláticos quanto intercumuláticos. Foram 
analisadas oito lâminas delgadas e duas sessões polidas e, como um todo, foram analisados 56 grãos de olivina, 129 de ortopiroxênio, 51 de clinopiroxênio, 91 de plagioclásio, 19 de feldspato, 17 de biotita, 100 de pirrotita, 21 de calcopirita, 12 de pirita, 31 de pentlandita, 6 de cromita e 11 de ilmenita.

Além das análises realizadas em rochas do complexo, foram feitas análises de microssonda para amostras de granulitos regionais. Essas análises foram utilizadas para o modelamento geotermobarométrico parcial do Complexo de Damolândia, que será detalhado mais à frente. Aamostra DM 19 apresenta mineralogia exótica. Nessa lâmina foram realizadas análises de 15 grãos de plagioclásio, 28 de granada e 7 de clinopiroxênio.

\subsection{Análise litogeoquímica de rocha total}

As análises litogeoquímicas foram realizadas pelos laboratórios AcmeLabs, localizados em Vancouver. Oito amostras foram selecionadas tanto das partes preservadas quanto das recristalizadas. As amostras foram fracionadas e pulverizadas e então $0,5 \mathrm{~g}$ de cada amostra foi dissolvida em aqua regia por uma hora e em seguida, foi diluida em $10 \mathrm{ml}$ de água desmineralizada. Essa solução foi então analisada para elementos maiores e menores, bem como para 53 elementos traço utilizando o pacote Litho Acme AA (códigos: 4BWR, 1FMS E 3BFG). Como parte de seu padrão de controle foram inseridas duplicatas e análises padrões juntamente com as amostras do CD analisadas.

\section{Resultados}

\subsection{Geologia e petrologia do Complexo de Damolândia}

O presente estudo busca descrever em detalhe o Complexo Máfico-Ultramáfico Acamadado de Damolândia (CD). O Estudo anterior de Della Giustina et al. (2011a) descreve em parte a mineralogia do complexo mas tem como foco a datação dessas rochas. O mapa geológico aqui apresentado (figura 3) foi confeccionado durante o mapeamento do CD pela International Nickel-Venture Ltd. e foi apresentado originalmente no trabalho anteriormente citado.

Conforme já mencionado, o CD ocorre entre granulitos e gnaisses de alto grau do Complexo Anápolis-Itauçu (Della Giustina et al., 2011a). Apresenta-se como um corpo composto por rochas máfica-ultramáficas acamadadas com direção EW. Por se apresentar probremente exposto a mineralogia do complexo foi melhor detalhada pelo furo de sondagem FSDM07 (indicado na figura 3), pelas lâminas delgadas e sessões polidas confeccionadas a partir desse furo de sondagem. 


\subsubsection{Zona Ultramáfica}

O furo de sondagem FSDM07 evidencia que a Zona Ultramáfica ocupa posição estratigráfica central. Consiste em uma sequência acamadada intercalada de harzburgito e piroxenitos (olivina piroxenito e ortopiroxenito), sendo que harzburgito é mais abundante na porção central da Zona Ultramáfica. Os piroxenitos, apesar de ocorrer intercaladamente com harzburgito, concentram-se no topo e na base da Zona Ultramáfica, encapsulando o harzburgito central. Esse encapsulamento fica bem marcado pela variação críptica nos teores de Fo e En, principalmente, que será detalhado no subitem de química mineral. De maneira semelhante, a transição da Zona Ultramáfica para a máfica não é abrupta mas sim gradual, marcada principalmente pela redução nos teores de Fo, En e An bem como por aumento na quantidade de plagioclásio (plg) intersticial em direção às rochas máficas.

A principal rocha que contém olivina (ol) é harzburgito, que consiste em cumulatos de olivina, ortopiroxênio (opx) e, de maneira mais restrita, clinopiroxênio (cpx) e cromita (chr). A quantidade de olivina é variável do olivina ortopiroxenito (cumulatos de ol $+\mathrm{opx} \pm \mathrm{chr}$ ) ao ortopiroxenito (cumulatos de opx + ol + \pm chr \pm cpx). Esses diferentes litotipos, harzburgito, olivina ortopiroxenito e ortopiroxenito, ocorrem em camadas intercaladas que podem chegar a até algumas dezenas de centímetros de espessura, mas que costumam ser mais discretas. As texturas ígneas primárias variam de meso a ortocumuláticas em harzburgito e piroxenitos. Harzburgito costuma apresentar grãos anedrais poiquilíticos e de granulação grossa de ortopiroxênio, englobando grãos anedrais de olivina, cercados por agregados de cristais euédricos de granulação média a grossa de olivina. Em contato abrupto com as porções onde mineralogia e textura ígnea se encontram preservadas ocorrem porções recristalizadas, com textura granoblástica e granulação que varia de média a fina. A associação mineralógica dessas porções recristalizadas é semelhante à observada nas porções preservadas. Os grãos de olivina se encontram amplamente preservados, apresentando pouca ou nenhuma serpentinização. A cromita ocorre como fase cumulática principalmente em harzburgito, mas também, em piroxenitos, o que sugere cristalização cotética.

Ortopiroxenito ocorre de maneira intercalada com as demais rochas ultramáficas, apresentando maior expressividade tanto em direção ao topo quanto à base da Zona Ultramáfica, dominada principalmente por harzburgito. Apresenta granulação média a grossa, com texturas variando de adcumuláticas a mesocumuláticas, sendo essa última caracterizada pela presença intersticial de plagioclásio e, de maneira mais restrita, de clinopiroxênio cumulático. Cromita também ocorre de maneira restrita, sendo fase acessória no ortopiroxenito, marcando a transição de cumulatos de ortopiroxênio + cromita para cumulatos de ortopiroxênio, tanto em direção ao topo quanto à base da Zona Ultramáfica. 
Conforme mencionado, texturas e mineralogias ígneas primárias se encontram extensivamente preservadas. O metamorfismo superimposto é heterogêneo e caracterizado por porções recristalizadas de granulação fina em contato com as porções preservadas de granulação grossa. Raros cristais de ortopiroxênio e olivina se encontram totalmente substituídos e, portanto, pseudomorfos não são comumente observados. Olivina se encontra pouco serpentinizada e ortopiroxênio altera para cummingtonita e biotita, formando os raros pseudomorfos.

\subsubsection{Zona Máfica:}

As rochas máficas se encontram tanto no topo quanto na base do complexo, no contato com as encaixantes. A Zona Máfica pode ser separada em Zona Máfica de Base e Zona Máfica de Topo, serão tratadas individualmente. A Zona Máfica de Base é composta por camadas intercaladas de gabro e norito sendo esse último mais abundante na transição gradual da Zona Ultramáfica para a Zona Máfica de Base. Tanto o gabro quanto o norito são compostos por cumulatos de ortopiroxênio \pm clinopiroxênio e quantidades variáveis de plagioclásio intersticial nas porções com mineralogia e textura ígnea preservadas. Grãos poiquilíticos de ortopiroxênio e clinopiroxênio são comuns nas rochas máficas da base (figura 4d). Assim como ocorre na Zona Ultramáfica, porções recristalizadas ocorrem em contato com as porções preservadas. A associação mineralógica dessas porções recristalizadas se assemelha às associações observadas nas porções preservadas, com a diferença na granulação que nas porções recristalizadas é fina, bem como na ocorrência de biotita e anfibólios como produto de alteração das fases cumuláticas. Grãos de ortopiroxênio são parcial a totalmente substituídos por cummingtonita e biotita, porém isso ocorre de maneira mais restrita, sendo escassos pseudomorfos observados, assim como na Zona Ultramáfica. Na transição da Zona Ultramáfica para a Zona Máfica as fases sulfetadas são mais abundantes e proeminentes. Apresentam mineralogia Mossulfide Solid Solution (MSS) típica e granulação variando de fina (nas porções recristalizadas) a grossa (nas porções preservadas). Pirrotita é a principal fase sulfetada sendo que sua cristalização predomina sobre as demais. Pentlandita ocorre exclusivamente como exsoluções (flames) em pirrotita, não tendo sido observado qualquer grão isolado e bem formado ao longo do CD. Calcopirita ocorre principalmente como inclusão nas bordas da pirrotita, mas também como grãos isolados subarredondados a arredondados nas porções recristalizadas. Grãos isolados subarredondados a arredondados de pirrotita também são observados nas

porções recristalizadas, mas apresentam pouca ou nenhuma exsolução de pentlandita. Óxidos como rutilo e ilmenita ocorrem como fase acessória, assim como zircão.

Na transição entre a Zona Ultramáfica e Máfica de Base se observa uma rocha de composição quartzo-aluminosa exótica às demais rochas do $\mathrm{CD}$, que foi interpretada como sendo um xenólito. A 
associação mineralógica desse xenólito consiste em feldspato potássico + cianita. O feldspato potássico apresenta teores expressivos de $\mathrm{Ba}$, o que permite que seja classificado como hialofana, mas isso será discutido em mais detalhe no sub item silicatos. A presença da hialofana com cianita pode ser indicativo de metassomatismo coevo ao reequilíbrio da rocha em fácies anfibolito.

A Zona Máfica de Topo é marcada pela presença de gabronorito tardio. A transição da Zona Ultramáfica para a Zona Máfica de Topo é mais uma vez gradacional, sendo igualmente marcada pela redução nos teores de Fo, En e An e por aumento na quantidade de plagioclásio intersticial. Ao contrário do gabro e do norito da Zona Máfica de Base, o gabronorito da Zona Máfica de Topo apresenta textura e mineralogia ígnea quase totalmente alterada. Essa rocha apresenta foliação pervasiva mais evidente em lâmina delgada (figura 4f), grãos de orto e clinopiroxênio são amplamente substituídos no retrometamorfismo por cummingtonita e pseudomorfos são abundantes nessa rocha. A cummingtonita é posteriormente alterada para hornblenda

$$
\begin{gathered}
\text { Opx } \rightarrow \text { Cumm } \rightarrow \text { Hbl } \\
3 \mathrm{Cumm}+14 \mathrm{An}+\mathrm{H}_{2} \mathrm{O} \rightarrow 7 \mathrm{Hbl}+10 \mathrm{SiO}_{2}
\end{gathered}
$$

Filossilicatos e anfibólios, predominantemente biotita e hornblenda, marcam a foliação, mas a ilmenita também assim o faz. Zircão ocorre como importante fase acessória e por meio dele é possível identificar duas gerações de ilmenita: sendo uma inclusa em zircão, com exsoluções de hematita e outra como produto do reequilíbrio em alto grau da rocha, acompanhando a foliação (figura 5l). Nos contatos entre os grãos de ilmenita e plagioclásio, hornblenda retrometamórfica pode ser identificada, sendo a reação proposta

$$
\mathrm{Plg}+\mathrm{Ilm} \rightarrow \mathrm{Hbl}
$$

Calcopirita e pirita ocorrem de maneira disseminada como grãos finos subarredondados a arredondados e estão associados à biotita retrometamórfica, sugerindo relação sin-tectônica entre esses minerais. O gabronorito tardio é interpretado como sendo resultado da cristalização de magma evoluído aprisionado nos estágios finais de formação do CD. 


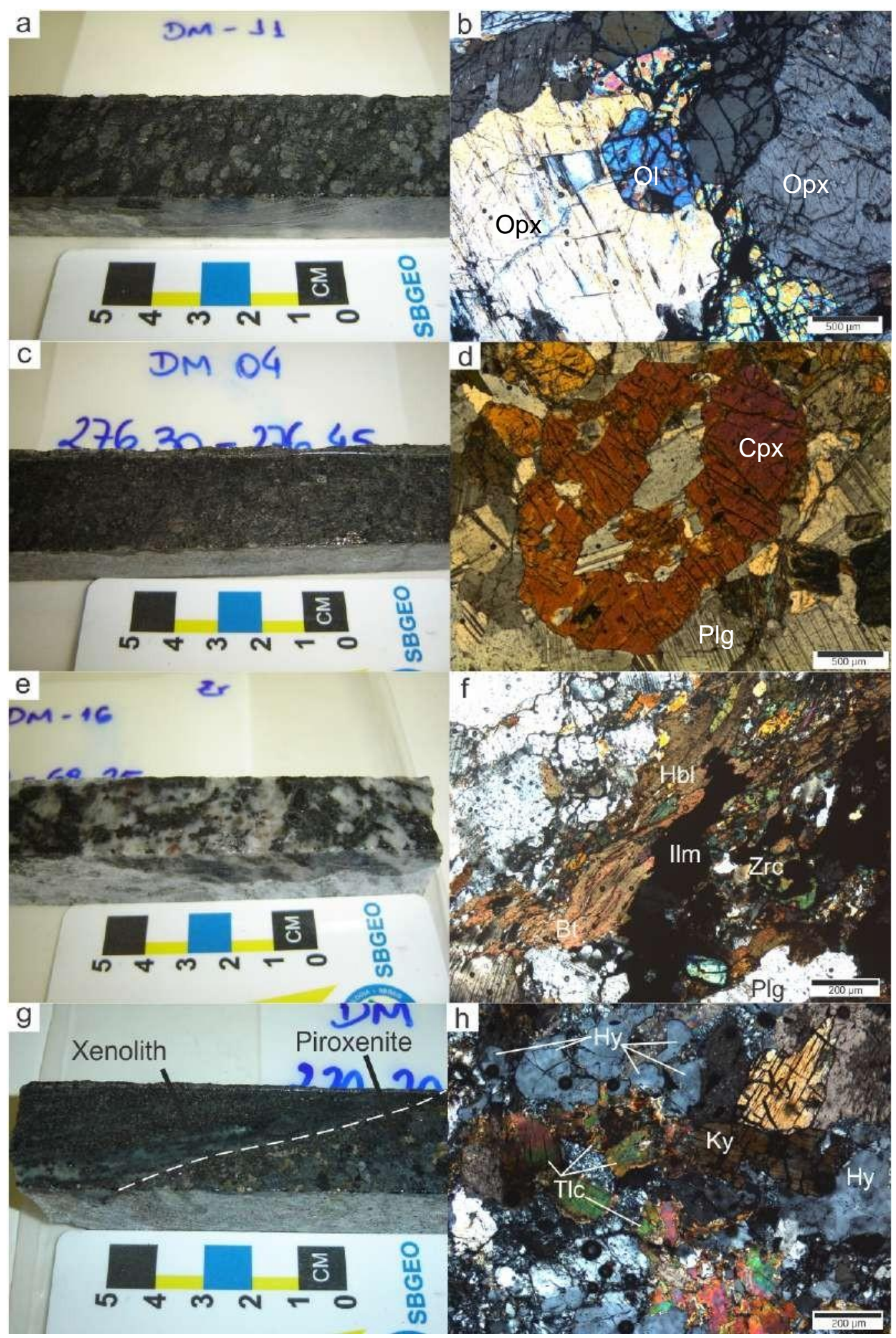

Figura 4: a) Harzburgito da Zona Ultramáfica do furo de sondagem FSDM07; b) Fotomicrografia do harzburgito com olivina cumulática inclusa em oikocrist de ortopiroxênio; c) Norito da Zona Máfica de Base do furo de sondagem FSDM07; d) Fotomicrografia do gabro com grãos reliquiares de clinopiroxênio cumulático e plagioclásio; e) Gabronorito tardio da Zona Máfica de Topo do furo de sondagem FSDM07; f) Fotomicrografia do gabronorito tardio evidenciando a granulação fina e foliação pervasiva marcada pelos filossilicatos e anfibólios; g) Piroxenito trasicional entre a Zona Ultramáfica e Máfica do furo de sondagem FSDM07 evidenciando o xenólito que ocorre nessa porção; h) Fotomicrografia do xenólito evidenciando a mineralogia exótica às demais rochas do complexo, com hialofana e cianita e talco, possivelmente como produtos de metassomatismo. 


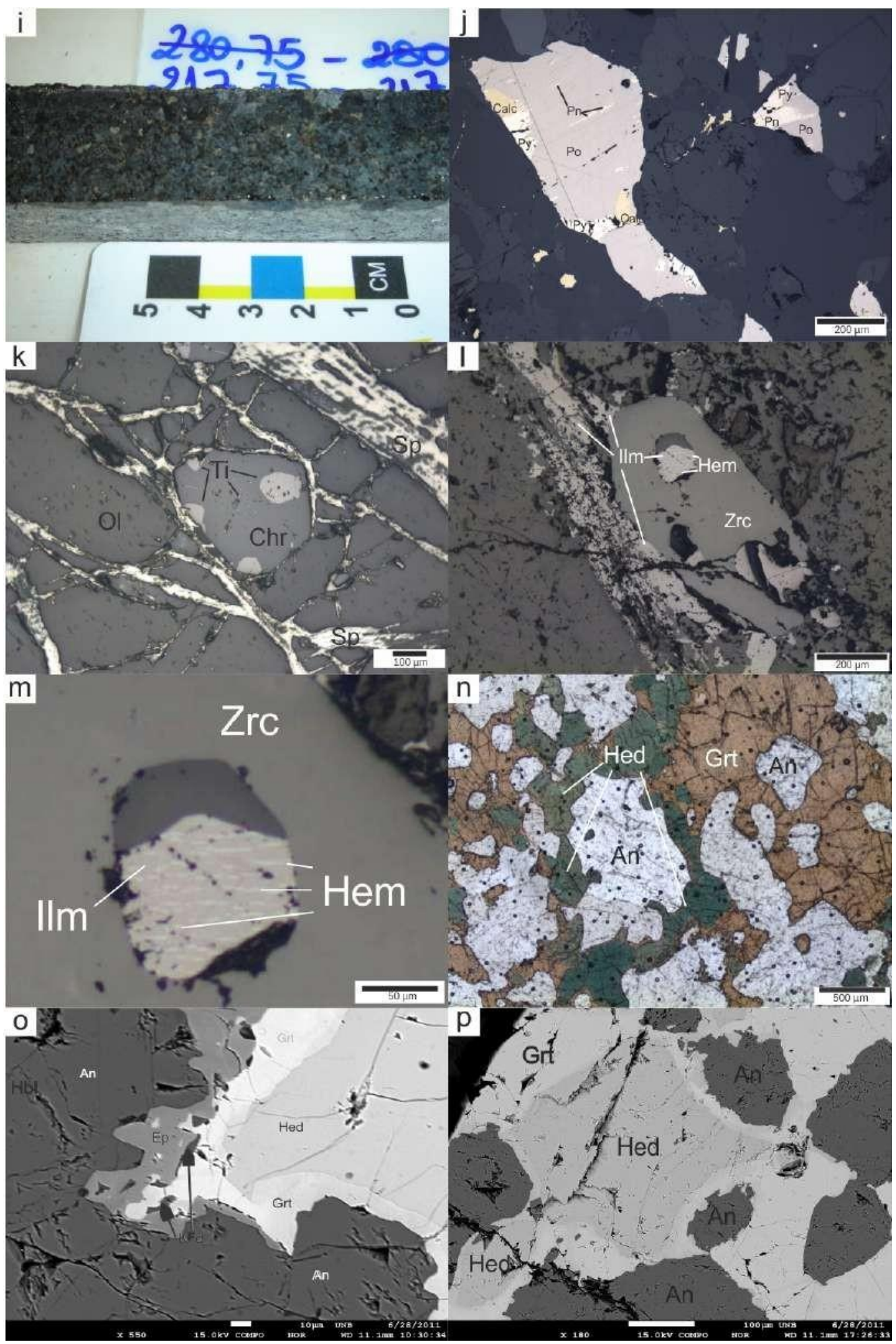

Figura 5: i) Piroxenito de transição entre a Zona Ultramáfica e máfica onde os sulfetos disseminados são mais abundantes (do furo de sondagem FSDM07); j) Foto da sessão polida do piroxenito evidenciando os grãos de pirrotita, que compõem a fase sulfetada predominante, de granulação média a grossa com inclusões de calcopirita e pirita e exsoluções ( flames) de pentlandita; k) Fotomicrografia de cromita com exsolução de titânita mais abundante na Zona Ultramáfica; 1) Fotomicrografia do zircão acessório no gabronorito tardio da Zona Máfica de Topo evidenciando as duas gerações de ilmenita observadas, sendo uma inclusa no zircão e outra acompanhando a foliação; m) Detalhe da ilmenita com exsolução de hematita inclusa no zircão; n) Fotomicrografia do granada-hedembergita granulito evidenciando a textura granoblástica da associação mineralógica do pico do metamorfismo granada + hedembergita + anortita; o) Imagem do microscópio eletrônico de varredura evidenciando as coronas de reação entre a granada e o clinopiroxênio (hedembergita); e p) Imagem do microscópio eletrônico de varredura do granada-hedembergita granulito evidenciando a intrínseca relação entre a granada e o clinopiroxênio. 


\subsubsection{Granulito a Dois Piroxênios}

Uma amostra de granulito a dois piroxênios foi coletada cerca de $5 \mathrm{~km}$ do CD (DM 20). Apresenta foliação e granulação média a grossa. Apresenta granulação fina a média e em algumas porções as texturas e mineralogias ígneas primárias ainda persistem, mas, de forma geral, apresentam uma alteração dos minerais. Piroxênio + clinopiroxênio \pm olivina compõem as principais fases cumuláticas e plagioclásio e biotita as principais fases intercumuláticas nas porções preservadas mas de maneira geral, apresenta textura granoblástica. Sulfetos observados nessa rocha são arredondados e com poucas inclusões, sendo em sua maioria pirrotita e calcopirita. As análises químicas, que serão detalhadas mais a frente, evidenciam que nessa rocha os menores teores de En e An são observados. Essa amostra foi analisada a fim de melhor contextualizar as rochas do CD no CAI (figura 3).

\subsubsection{Granada-hedembergita granulito}

Dentre os granulitos regionais coletados nas proximidades do CD, a rocha DM19 foi coletada nas coordenadas $0676473 \mathrm{~L} / 8198150 \mathrm{~N}$ (figura 3), em contato com o CD. Consiste em rocha holocristalina, de granulação média a fina e com cristais xenomórficos. É composta por aproximadamente $45 \%$ de plagioclásio, $35 \%$ de granada e $20 \%$ de clinopiroxênio. Com a exceção de um veio de granada visível em lâmina delgada, a rocha apresenta-se homogênea. Observam-se também em lâmina delgada evidências microestruturais que permitem a identificação de alterações ocorridas durante o metamorfismo progressivo dessa rocha. Tais microestruturas se manifestam na forma de halos de alteração entre a granada (grossulária) e o clinopiroxênio (hedembergita) que pode ser descrita pela reação seguinte:

$$
\text { 2Grossulária + Almandina + 3quartzo = 3Anortita +3Hedembergita }
$$

A quantidade de quartzo observada é restrita e ocorre apenas como pequenas inclusões em granada. Isso é interpretado como sendo devido ao fato do quartzo nessa rocha ter sido quase totalmente consumido na reação proposta acima, que resultou na formação da hedembergita durante o pico do metamorfismo.

Esse granulito apresenta mineralogia que não é diagnóstica de metamorfismo UHT mas que pode atingir essas condições e, portanto, foi modelada geotermobarometricamente por métodos convencionais e otimizados, o que será detalhado nos próximos itens. Os minerais observados nessa rocha foram descritos em detalhe no capítulo de geoquímica, no sub item silicatos. 


\subsection{Química mineral}

Os valores composicionais dos cristais de olivina não apresentam variação significativa no harzburgito da Zona Ultramáfica, com teores que variam entre Fo ${ }_{81,9}$ e Fo89,5, indicando composições primitivas. O mesmo ocorre nas rochas máficas, com teores de Fo70-72. Observa-se leve variação entre os teores de Fo e as profundidades estratigráficas, sendo os valores mais altos de Fo observados na Zona Ultramáfica e os menores nas Zonas Máficas de base e topo. Ao contrário do que ocorre para a maioria dos complexos MUM descritos na região a estratigrafia do CD não se apresenta invertida mas sim, normal, com núcleo de rochas ultramáficas tanto no topo quanto na base por rochas máficas. Essa suposição fica mais clara, observando-se a figura 6 que compara, entre outros, os teores de Fo, En e An com a estratigrafia do CD. O conteúdo de Ni em olivina do harzburgito varia de 2145 até 660 ppm, em olivina do olivina ortopiroxenito varia de 1626 até 565 ppm e na olivina do norito varia de 966 até 275 ppm. Conforme pode ser observado na figura 7, o conteúdo de $\mathrm{Ni}$ na olivina não é positivamente correlacionado aos teores de Fo o que é corroborado por teores variáveis de Ni para teores semelhantes de Fo ( Fo82). Essa ausência de correlação positiva pode ser associada à segregação de sulfetos durante a evolução magmática do CD ou devido a novas injeções de magmas depletados em Ni.

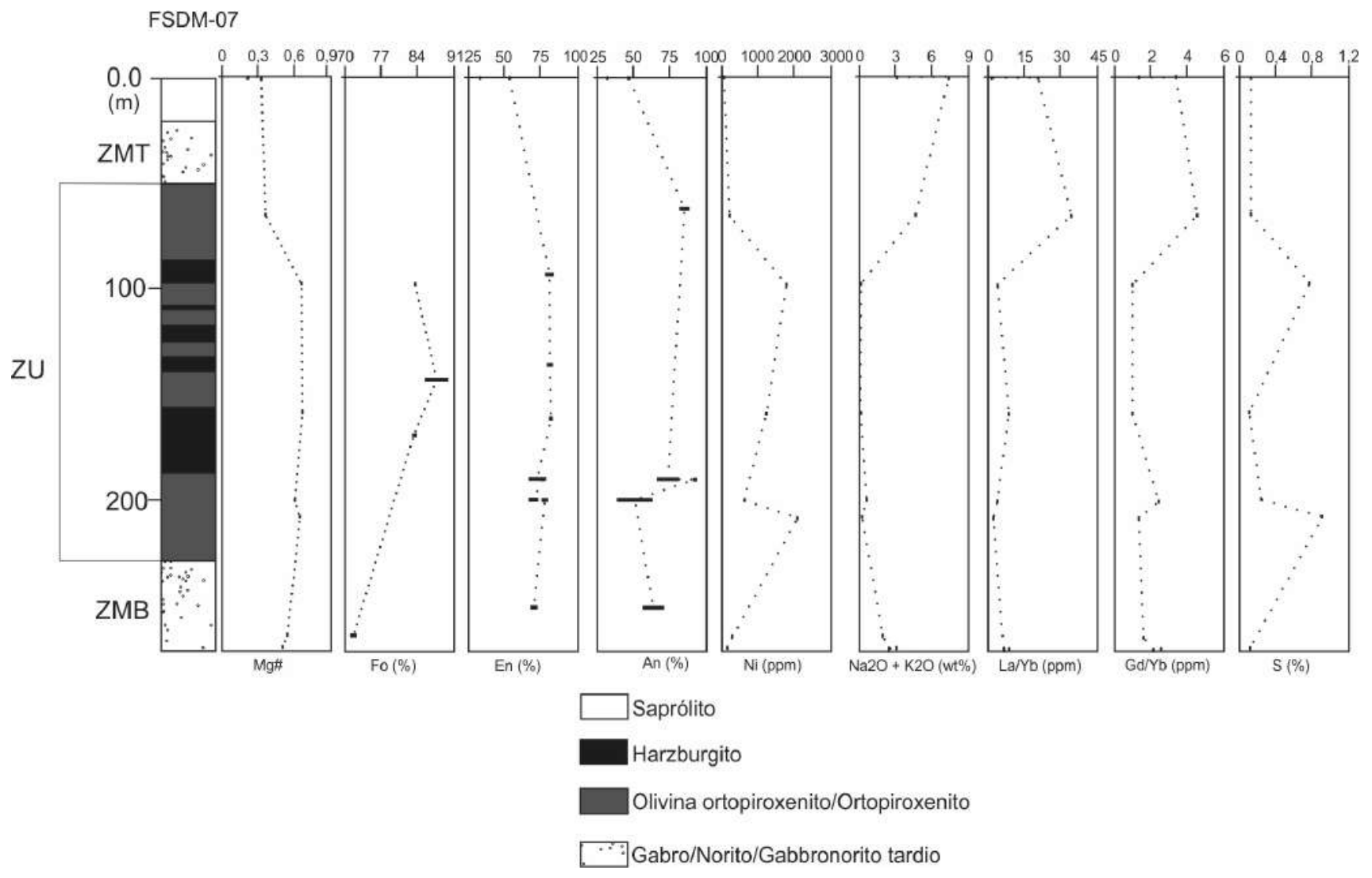

Figura 6: Comparação dos teores de Mg\#, Fo (\%), En (\%) e An (\%) calculados com base em dados de microssonda eletrônica para as fases minerais e $\mathrm{Ni}(\mathrm{ppm}), \mathrm{Na}_{2} \mathrm{O}+\mathrm{K}_{2} \mathrm{O}(\mathrm{wt} \%), \mathrm{La} / \mathrm{Yb}(\mathrm{ppm}), \mathrm{Gd} / \mathrm{Yb}(\mathrm{ppm})$ e $\mathrm{S}(\%)$ calculados com base nos dados de rocha total, versus a estratigrafia do Complexo de Damolândia proposta por Della Giustina et al (2011a). ZU = Zona Ultramáfica, ZMB = Zona Máfica de Base e ZMT = Zona Máfica de Topo. 


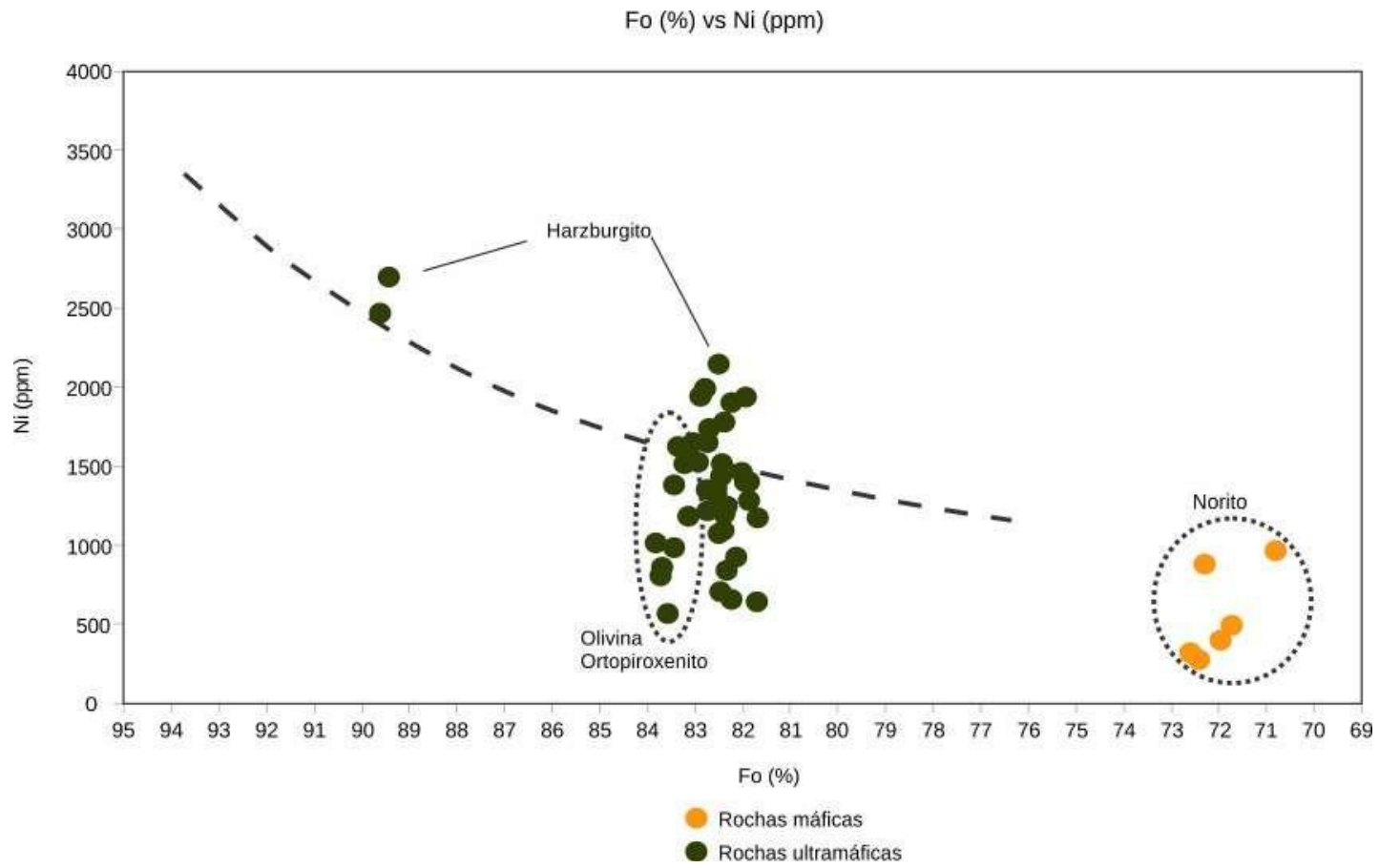

Figura 7: Variação dos teores de Fo (\%) versus os teores de Ni (ppm) para as rochas do Complexo de Damolândia. A linha pontilhada representa o trend composicional para a olivina de complexos acamadados (Simkin and Smith, 1970).

Cristais de ortopiroxênio apresentam variação composicional no harzburgito da Zona Ultramáfica primitiva, entre $E_{83,7}$ e $E_{78,1}$ nas porções preservadas e variando entre En70 e En67 nas porções recristalizadas. A variação composicional na porção máfica fica entre $\operatorname{En}_{79}$ a $\operatorname{En}_{72}$ nas porções preservadas e entre En67 e En66 nas porções recristalizadas e no xenólito observado na transição das rochas ultramáficas para máficas, indicando composição mais fracionada para o gabro e norito do complexo. Os valores superiores de En são observados na porção central da Zona Ultramáfica, sendo o mesmo trend observado nos teores de En da rochas máficas, sugerindo maior fracionamento em direção às bordas do complexo e um núcleo mais primitivo. Vale ressaltar que muitos dos cristais preservados de ortopiroxênio apresentam clinopiroxênio incluso em suas estruturas.

Valores composicionais para o plagioclásio, de forma semelhante aos demais minerais aqui descritos, foram obtidos tanto a partir de rochas reliquiares quanto recristalizadas. Um grande intervalo composicional pode ser observado para o plagioclásio analisado, variando de An94,8 e An33.5. Cristais de plagioclásio com as composições mais primitivas ( $\mathrm{An}_{94,8}$ a $\mathrm{An}_{80,0}$ ) foram observados em piroxenito da Zona Ultramáfica (amostras DM09 e DM10) em profundidades variando de 209,25 a 209,45 metros. Cristais de plagioclásio que apresentam composições mais fracionadas, variando de An49.4 a An40.1, foram observados em norito e na porção transicional das rochas máficas para as ultramáficas, (amostras DM04 e DM06) em profundidades variando entre 276,30 e 220,40 metros, respectivamente, no topo da Zona Máfica de Base do complexo. Vale mencionar também que a amostra do granulito regional a dois 
piroxênios apresentou o menor teor, com valor de $\mathrm{An}_{33,4}$. Teores de An observados no xenólito variam na ordem de $\mathrm{An}_{64.3}$ ate $\mathrm{An}_{40.1}$ e no granada-hedembergita granulito variam de An92.8 ate An85.8, sendo os valores de An observados no granada-hedembergita granulito são maiores do que os observados para as rochas da Zona Ultramáfica do CD.

Feldspato potássico com teores significativos de Ba é observado no $\mathrm{CD}$, mais especificamente, na transição da Zona Ultramáfica para a Zona Máfica de Base. Tal porção é interpretada como sendo um xenólito, o que pode ser observado na figura 4e. Nessa transição (topo das rochas máficas e base das rochas ultramáficas) variação composicional da molécula de celsiana apresenta teores entre $\mathrm{Cel}_{12,6} \mathrm{e}$ $\mathrm{Cel}_{4,8} \mathrm{e}$, por apresentar teores significativos, o feldspato potássico pode ser classificado como hialofana. A química desse xenólito será melhor descrita nos sub itens subsequentes.

\subsection{1. Óxidos e Sulfetos}

Óxidos e sulfetos ocorrem disseminadamente ao longo do $\mathrm{CD}$, mas são mais expressivos na transição das rochas máficas para as ultramáficas e no gabronorito tardio. Os sulfetos do CD apresentam mineralogia Monosulfide Solid Solution (MSS) típica com a cristalização de pirrotita predominando sobre pentlandita e calcopirita. Em algumas rochas gabróicas calcopirita e pirita ocorrem como grãos pequenos e isolados. Harzburgito apresenta predominância de cromita cumulática sobre os demais óxidos e sulfetos.

Pirrotita: observada ao longo de toda a estratigrafia e sua ocorrência predomina sobre a dos demais sulfetos. Ocorre como mineral intercumulático de granulação média a grossa e com contatos bem definidos, além de ser observado como inclusões em ortopiroxênio de norito e harzburgito. Geralmente tem exsoluções (flames) de pentlandita. Encontra-se mais bem preservada em piroxenito de transição das rochas ultramáficas para máficas. Nesse piroxenito observam-se valores apfu de Ni na ordem de 0 a 0,095, Co de 0,04 a 0,109 e $\mathrm{Cu}$ de 0 a 0,191, sendo os menores valores comumente observados nas porções recristalizadas. Esses valores sugerem variabilidade restrita e homogeneidade composicional da fração de sulfetos do CD (figura 4a e b). Os grãos de pirrotita apresentam-se maiores e mais expressivos nas rochas que ainda apresentam textura ígnea preservada e de granulação média a grossa. Nas rochas recristalizadas, os grãos de pirrotita são arredondados a subarredondados e as exsoluções de pentlandita não são evidentes ou não estão presentes.

Pentlandita: ocorre como exsoluções (flames) em pirrotita, não tendo sido observado qualquer grão bem formado de pentlandita. As rochas ultramáficas apresentam valores apfu de Co de 0,28 a 2,018, sendo os maiores valores observados no piroxenito transicional e apresentam razão Ni/Co em torno de 25, com ocasionais valores mais altos, podendo chegar a 107,4 em rochas ultramáficas. 
Devido ao fato dos sulfetos nas porções recristalizadas apresentarem-se pequenos e com poucas exsoluções de pentlandita, não foi possível verificar se há variação composicional entre a pentlandita das porções com texturas e mineralogia ígnea primária preservada e das porções recristalizadas.

Calcopirita: ocorre associada a pirrotita e pirita. De maneira geral, não se desvia da composição química ideal, não apresentando teores expressivos de elementos contaminantes. No olivina ortopiroxenito e ortopiroxenito apresenta teores apfu de $\mathrm{Zn}$ da ordem de 0 a 0,114 , Se de 0 a $0,088, \mathrm{~Pb}$ de 0,006 a 0,238, Bi de 0 a 0,077, Te de 0 a 0,041, Co de 0 a 0,074, Sb de 0 a 0,178, Ni de 0 a 0,037, Au de 0 a 0,004, Ag de 0 a 0,025, Pd de 0 a 0,022, Pt de 0 a 0,009. Ocorre normalmente como inclusões nas bordas dos grãos de pirrotita ou, assim como a pirita, como pequenos grãos isolados arredondados nas porções recristalizadas. De maneira semelhante aos demais sulfetos observados no complexo, os menores valores observados para os elementos aqui descritos são normalmente observados em calcopirita das porções recristalizadas.

Pirita: compõe a fase sulfetada menos expressiva do CD e ocorre associada a pirrotita, sendo observados poucos grãos isolados de pirita. Apresenta valores apfu de $\mathrm{Zn}$ na ordem de 0 a 0,061, $\mathrm{Pb}$ de 0,104 a 0,242, Co de 0,017 a 3,595, $\mathrm{Cu}$ de 0 a 0,221 e $\mathrm{Ni}$ de 0 a 0,122. Por não ser fase sulfetada comumente observada em rochas máficas e ultramáficas com mineralogia MSS, a pirita observada é interpretada como sendo posterior, resultado de alteração devido a recristalização da rocha no metamorfismo.

Cromita: apresenta-se como grãos arredondados a subarredondados com coloração castanha. Ocorre de maneira restrita, sendo mais abundante em olivina ortopiroxenito e harzburgito das rochas ultramáficas. Apresenta valores apfu de Al na ordem de 1,494 a 1,526, Cr de 0,267 a 0,287, $\mathrm{Fe}^{+2} 0,462$ a 0,532, $\mathrm{Fe}^{+3}$ de 0,182 a 0,219 e Mg de 0,472 a 0,538. Exsoluções de Ti são observadas na cromita.

Ilmenita: ocorre de maneira restrita, sendo encontrada principalmente em ortopiroxenito da Zona Ultramáfica e em gabronorito tardio da Zona Máfica de Topo (figura 5 i e j). Em ortopiroxenito os grãos de ilmenita possuem granulação fina e são arredondados e em gabronorito tardio são verificadas duas gerações de ilmenita: uma inclusa em zircão e com exsoluções de hematita, indicativo de temperaturas de cristalização elevadas, e outra na matriz, deformada e acompanhando a foliação incipiente observada nessa rocha. Apresenta valores apfu de $\mathrm{Al}$ na ordem de 0 a 0,001, $\mathrm{Cr}$ de 0 a 0,006 e V de 0,008 a 0,015. Não foi possível verificar se há variação entre a composição da ilmenita inclusa e da matriz devido ao tamanho das inclusões dificultar as análises de microssonda. Além disso, as exsoluções de hematita dificultam a definição dos limites entre esses dois minerais. 


\subsubsection{Silicatos}

Olivina: é observada ao longo de todo o complexo e apresenta-se mais preservada nas rochas ultramáficas. Apresenta também granulação grossa e, em geral, seus grãos são pouco serpentinizados. Em norito da Zona Máfica de Base olivina apresenta valores apfu de Mg na ordem de 1,019 a 1,064, $\mathrm{Fe}^{+2}$ de 0,395 a 0,432, Mn de 0,005 a 0,10, Ca de 0,009 a 0,025, Cr de 0 a 0,002, $\mathrm{Fe}^{+3}$ de 0, Al de 0,063 a 0,080 e Ni de 275 a 966,5 ppm. Em harzburgito da Zona Ultramáfica olivina apresenta valores apfu de $\mathrm{Mg}$ na ordem de 1,648 a 1,677, $\mathrm{Fe}^{+2}$ de 0,274 a 0,333, Mn de 0,003 a 0,007, Ca de 0 a 0,001, Cr de 0 a $0,002, \mathrm{Fe}^{+3}$ de 0,010 a 0,038, Al de 0 a 0,001 e ppm de Ni na ordem de 707,21 a 1995,93. De maneira geral, os menores valores observados para os elementos aqui descritos ocorrem principalmente nas porções recristalizadas, o que se mostrou ser um trend observado na maioria dos minerais descritos no presente trabalho. O perfil composicional apresentado na figura 8, confeccionado a partir de valores apfu para certos elementos e de Mg\#, é quase paralelo mas é possível verificar leve empobrecimento de $\mathrm{Mg}$ nas bordas da olivina do harzburgito e enriquecimento de $\mathrm{Fe}^{+2}$, o que pode sugerir trocas tardias destes elementos durante um reequilíbrio ou retrometamorfismo. Associada a olivina de harzburgito, ocorre cromita que, apesar de ter sido observada em outras rochas do complexo é mais expressiva nessas rochas da Zona Ultramáfica. Vale ressaltar que as bordas dos grãos de olivina observados em harzburgito apresentam-se pouco serpentinizadas, o que pode ser observado na fotomicrografia da figura $5 \mathrm{k}$.

A figura 9 evidencia a diferença entre os teores de Fo de olivina observada nas porções preservadas das rochas e nas porções recristalizadas. Conforme pode ser observado na figura, as porções recristalizadas apresentam valores inferiores de $\mathrm{MgO}(\mathrm{wt} \%)$ e de Fo (\%) aos observados nas porções preservadas. 


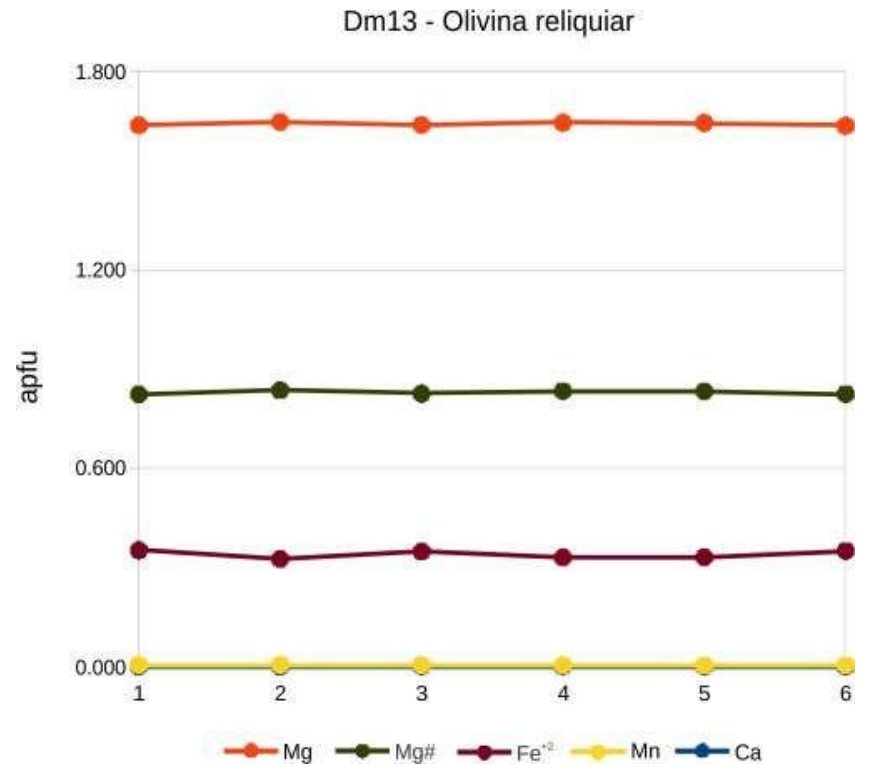

Figura 8: Perfil composicional de olivina reliquiar de harzburgito da Zona Ultramáfica do Complexo de Damolândia.

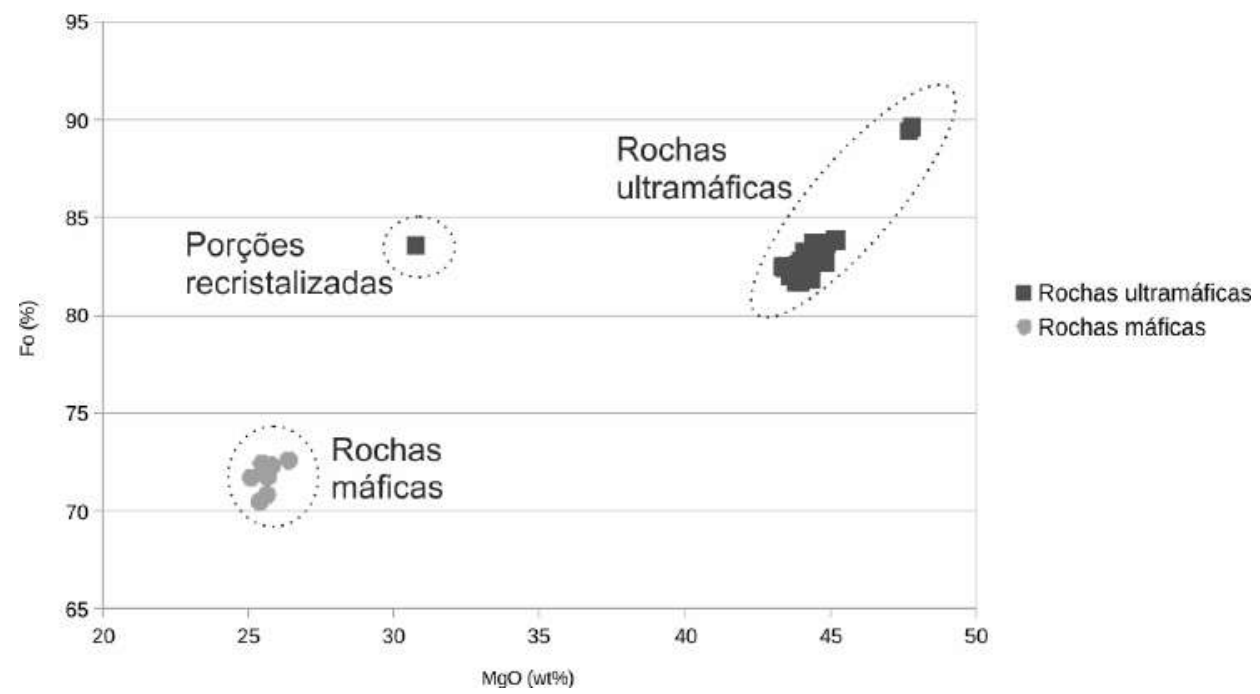

Figura 9: Gráfico de $\mathrm{MgO}$ (wt\%) versus os teores de Fo (\%) de olivinas das rochas ultramáficas e máficas do Complexo de Damolândia.

Piroxênios: nas porções preservadas, em que a textura ígnea reliquiar ainda pode ser observada, apresentam granulação grossa e são idiomórficos a subidiomórficos. Tanto na Zona Máfica de Base e de Topo quanto na Ultramáfica ocorrem como grãos cumuláticos, juntamente com olivina. Predomina no CD ortopiroxênio, alguns grãos com outros minerais inclusos, como plagioclásio e clinopiroxênio. Particularmente em gabronorito tardio alguns grãos de piroxênio foram completamente substituídos por hornblenda e biotita e são pseudomorfos, enquanto outros ainda se apresentam intensamente fraturados.

Ortopiroxênio (OPX) das rochas máficas, classificado na figura 10, apresentam valores apfu de Ca na ordem de 0,02, $\mathrm{Mg}$ de $1,5, \mathrm{Fe}^{+2}$ de 0,5, $\mathrm{Fe}^{+3}$ de 0,03, $\mathrm{Al}$ de 0,2 e $\mathrm{Mg \#} \mathrm{de} \mathrm{0,7.} \mathrm{Nas} \mathrm{rochas}$ 
ultramáficas apresentam valores apfu de Ca na ordem de 0,2, $\mathrm{Mg}$ de $1,5, \mathrm{Fe}^{+2}$ de 0,3, $\mathrm{Fe}^{+3}$ de $0,05, \mathrm{Al}$ de 0,2 e Mg\# de 0,8. Conforme pode ser observado nos perfis composicionais da figura 11, os cristais apresenta perfis de maneira geral homogêneos, sem muitas diferenças marcantes entre as bordas e o

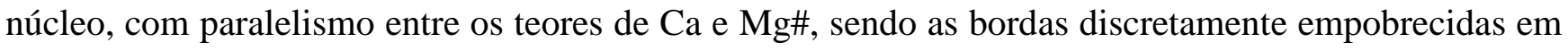
$\mathrm{Mg}$ e enriquecidas em $\mathrm{Fe}^{+2}$. Observa-se também correlação positiva entre $\mathrm{Al}$ e $\mathrm{Fe}^{+2}$. Essas discretas variações entre o núcleo e as bordas sugerem troca catiônica tardia de $\mathrm{Fe}-\mathrm{Mg}$ durante o retrometamorfismo.

A figura 12 mostra as relações entre os valores de $\mathrm{MgO}$ (wt\%) e de $\mathrm{FeO}$ (wt\%) e os teores de En (\%) das rochas do CD. A variação entre esse valores deixa bem evidente a diferença entre as porções preservadas e as recristalizadas, em que os teores de $\mathrm{MgO}$ e En são superiores nas porções preservadas. O granulito regional analisado também se diferencia bastante das rochas do CD, apresentando teores menores de En e MgO.

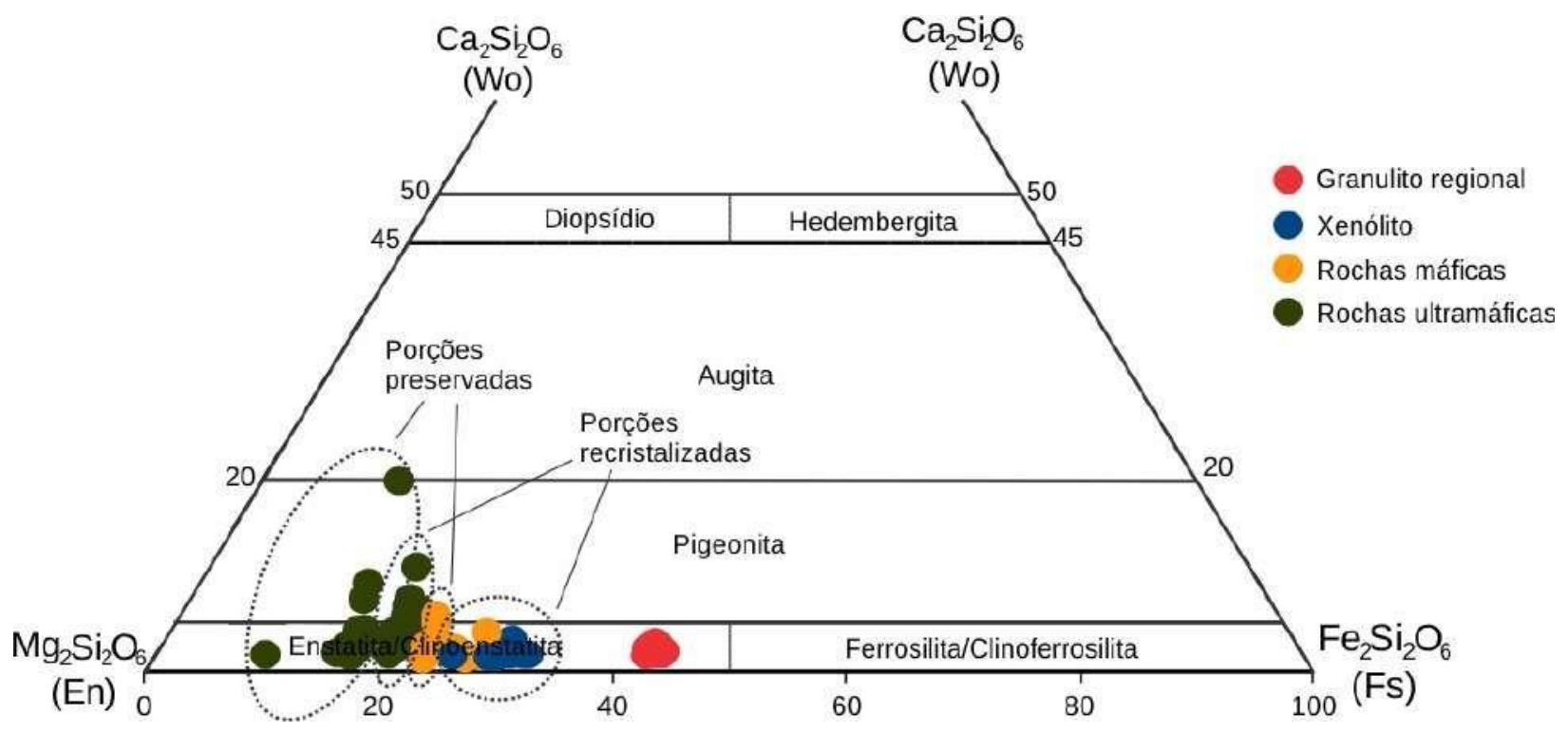

Figura 10: Gráfico de caracterização de ortopiroxênios do Complexo de Damolândia e do granulito regional. Os círculos pontilhados separam ortopiroxênios das porções preservadas e das porções recristalizadas, tanto para as rochas da Zona Máfica quanto ultramáfica. 

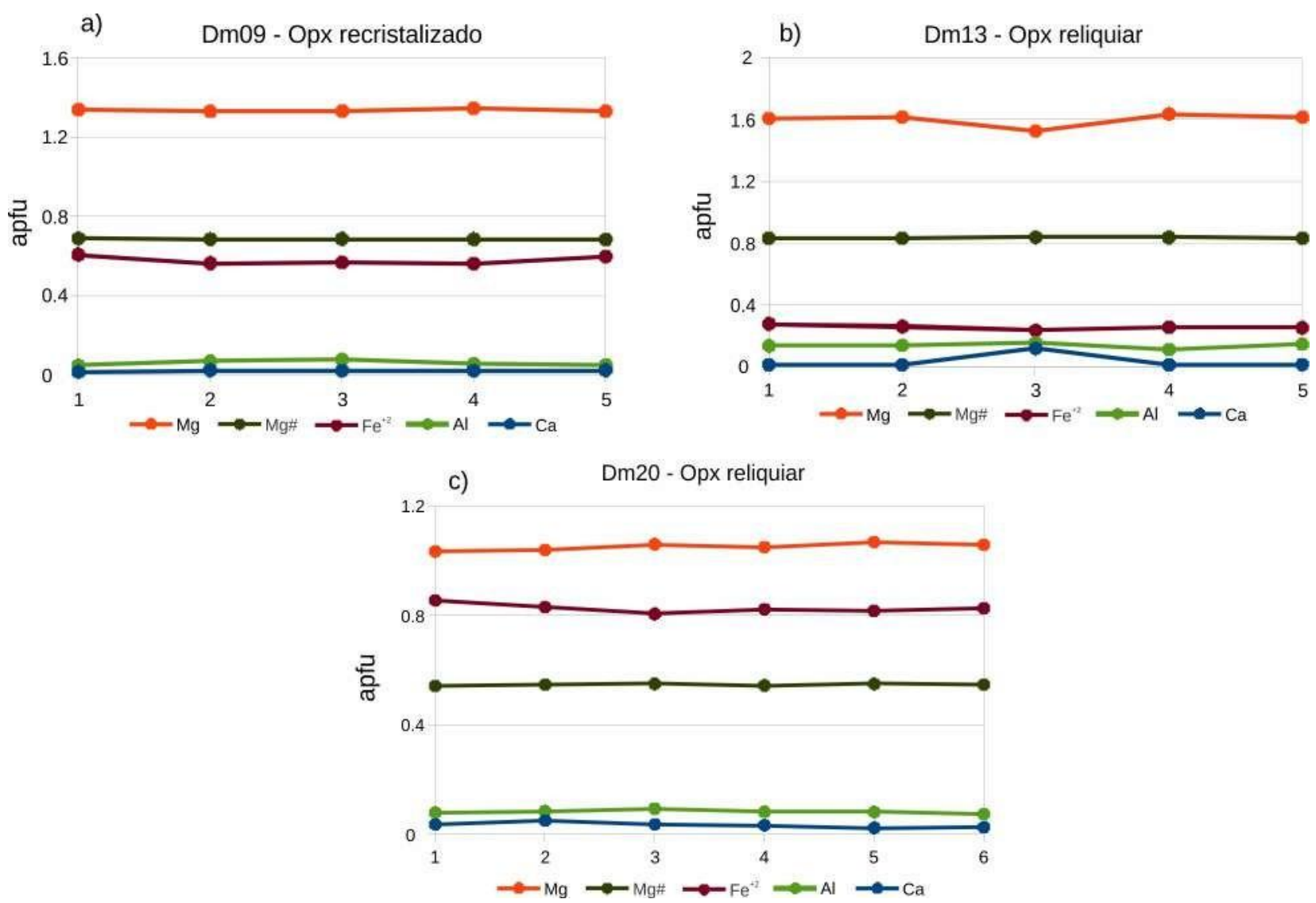

Figura 11: Perfis composicionais de ortopiroxênio do Complexo de Damolândia a) ortopiroxenito; b) harzburgito e c) granulito regional.
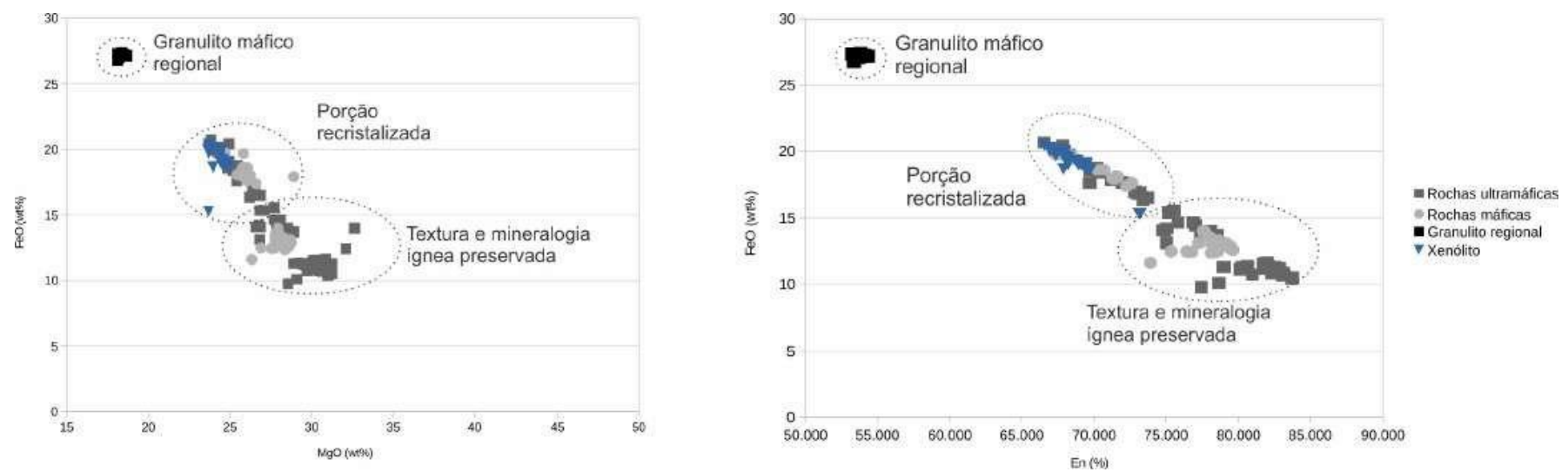

Figura 12: a) Gráfico de variação dos teores de $\mathrm{MgO}$ (wt\%) versus $\mathrm{FeO}$ (wt\%) das rochas do Complexo de Damolândia; e b) Variação dos teores de $\mathrm{En}(\%)$ versus $\mathrm{FeO}$ (wt\%). Os gráficos evidenciam a variação desses teores tanto para as porções preservadas quanto para as recristalizadas.

Clinopiroxênio (CPX) foi analisado nas rochas ultramáficas do complexo, no granulito regional e no granada-hedembergita granulito, já que nas rochas máficas não foram observados grãos representativos. O ortopiroxenito apresenta valores apfu de $\mathrm{Ca}$ na ordem de $0,9, \mathrm{Mg}$ de $0,7, \mathrm{Fe}^{+2} \mathrm{de}$ $0,15, \mathrm{Fe}^{+3}$ de 0,04, $\mathrm{Al}$ de 0,3 e valor de $\mathrm{Mg \#}$ na ordem de 0,8. Observa-se, de maneira semelhante ao 
ortopiroxênio, paralelismo entre os teores de $\mathrm{Ca}$ e de Mg\#. Mas ao contrário do OPX, o perfil composicional do CPX (figura 13) apresenta significativas oscilações, sendo mais enriquecidos em $\mathrm{Mg}$ no núcleo do que nas bordas (observa-se o oposto com Ca). Há significativa variação também nos valores de $\mathrm{Al}$ nos $\mathrm{CPX}$, sendo mais empobrecido nas bordas do que no núcleo. É possível observar alterações de borda do CPX para hornblenda, o que pode justificar a diminuição do Al nas bordas e apontar a hornblenda como sendo retrometamórfica. O clinopiroxênio do granulito regional, classificado na figura 14a, apresenta valores apfu de $\mathrm{Ca}$ na ordem de 0,9, $\mathrm{Mg}$ de 0,13, $\mathrm{Fe}^{+2} \mathrm{de} 0,6, \mathrm{Fe}^{+3}$ de 0,1, Al de 0,2 e valor de Mg\# de 0,13. De maneira semelhante aos demais minerais, os menores teores dos elementos aqui descritos foram observados nas porções recristalizadas das rochas em questão.
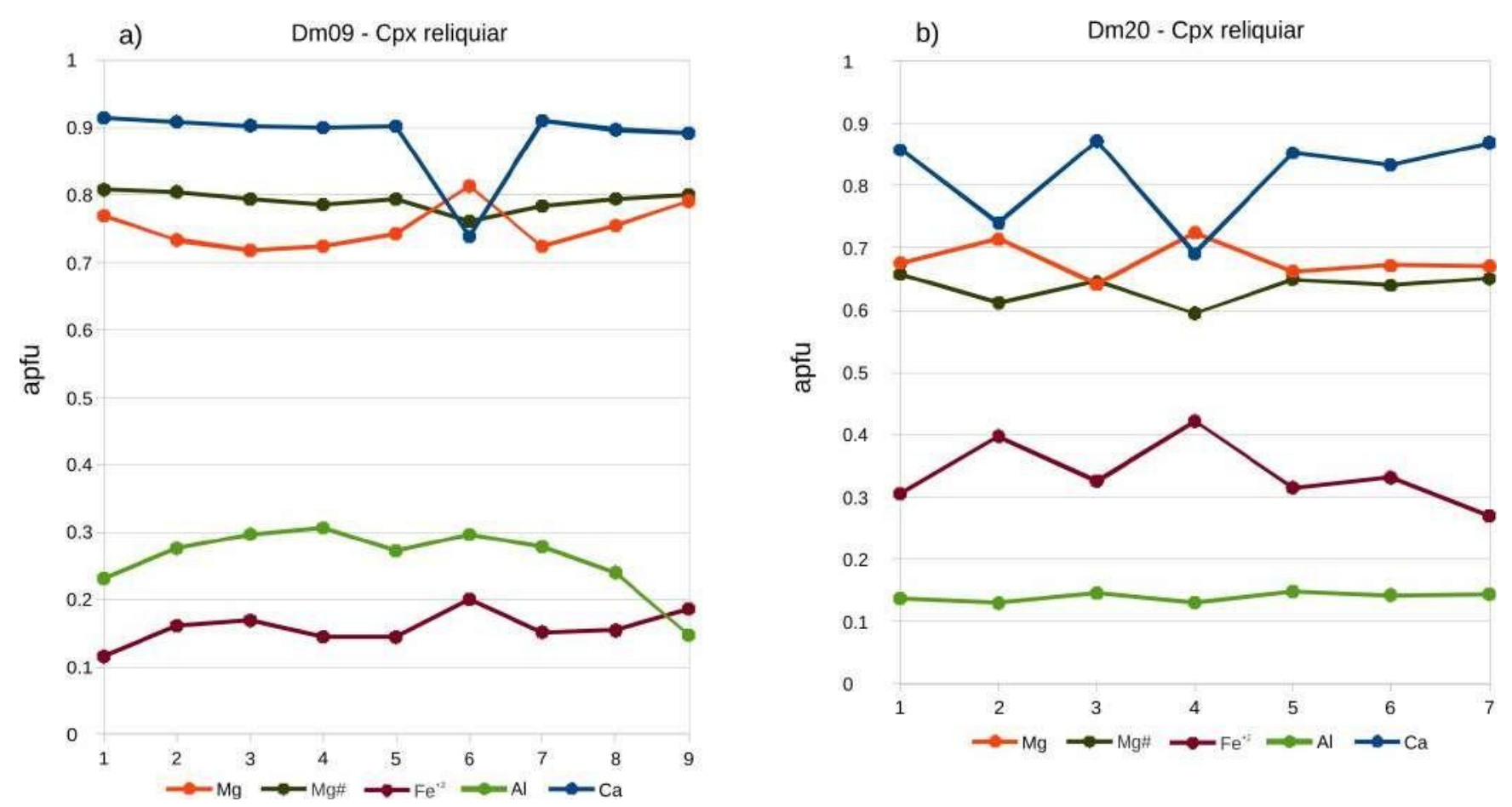

Figura 13: Perfis composicionais de clinopiroxênio do Complexo de Damolândia a) ortopiroxenito e b) granulito regional.

Clinopiroxênio do granada-hedembergita granulito apresenta coloração esverdeada distinta em nicóis paralelos e na maioria dos grãos são observadas bordas de reação com granada (de maneira simplificada, grs = hed). Os grãos analisados caem em sua totalidade no campo da hedembergita (figura 14b). Apresentam valores apfu de $\mathrm{Ca}$ na ordem de 0,94, $\mathrm{Mg}$ de 0,12 a 0,18, $\mathrm{Fe}^{+2}$ de 0.60 até 0,73, $\mathrm{Fe}^{+3} 0,08$ até $0,16, \mathrm{Al}$ de 0,16 até 0,28 e valores de $\mathrm{Mg \#}$ de 0,15 até 0,23. Não foram confeccionados perfis composicionais do clinopiroxênio do granada-hedembergita granulito. 

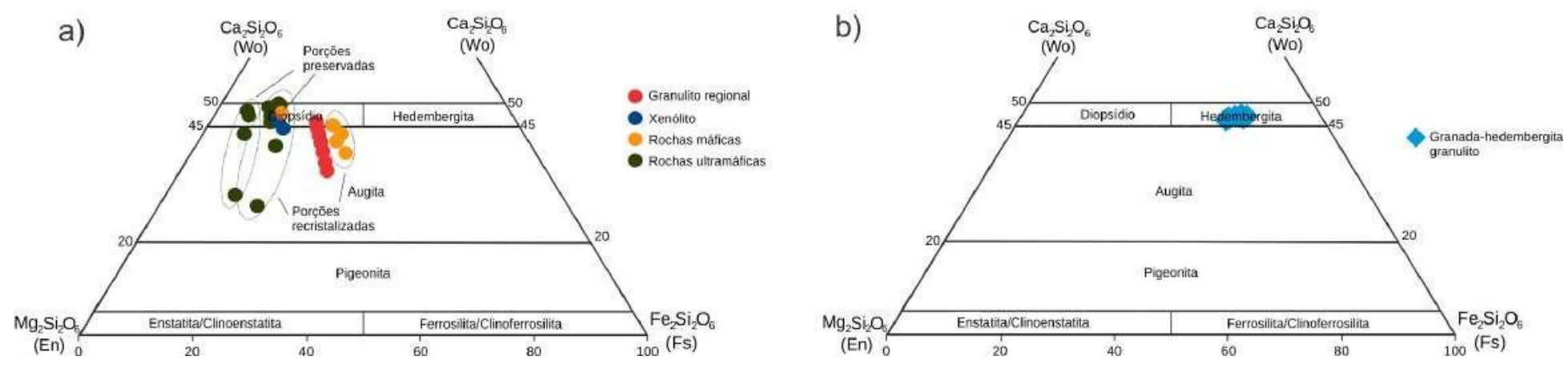

Figura 14: a) Gráfico de caracterização do clinopiroxênio das rochas do Complexo de Damolândia e do granulito regional; e b) Gráfico de caracterização do clinopiroxênio do granada-hedembergita granulito.
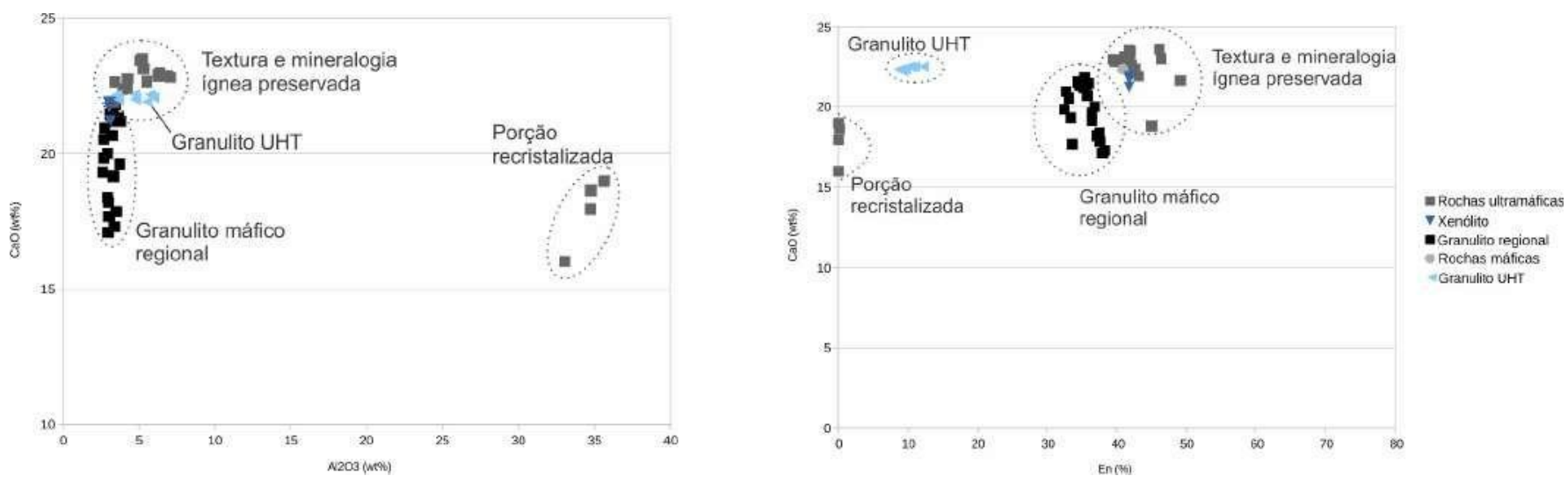

Figura 15: a) Gráfico dos valores de $\mathrm{Al}_{2} \mathrm{O}_{3}$ (wt\%) versus $\mathrm{CaO}$ (wt\%); e b) En (\%) versus $\mathrm{CaO}$ (wt\%), evidenciando a diferença desses valores entre as porções preservadas e as recristalizadas, para o granulito regional, o granada-hedembergita granulito e as rochas do Complexo de Damolândia.

Plagioclásio: é observado em todas as rochas do $\mathrm{CD}$, tanto as máficas e ultramáficas quanto no granulito regional e no granada-hedembergita granulito, ocorrendo em sua maioria como mineral intercúmulus nas porções com textura ígnea preservada e granoblástica nas porções recristalizadas. Buscou-se analisar plagioclásio pouco alterado e deformado. Nas rochas máficas plagioclásio apresenta valores apfu de $\mathrm{Na}$ na ordem de 0,3, $\mathrm{Ca}$ de $0,4, \mathrm{~K}$ de $0,06, \mathrm{Fe}^{+3}$ de 0,8 e teor de $\mathrm{An}_{58}$. As rochas ultramáficas apresentam valores apfu de $\mathrm{Na}$ na ordem 0,2 e 0,06, Ca de 0,7, $\mathrm{K}$ de 0,001, $\mathrm{Fe}^{+3}$ de 0,8 e teor de An90. Plagioclásio do granulito regional apresenta valores apfu de $\mathrm{Na}$ na ordem de 0,08, Ca de 0,9, $\mathrm{K}$ de 0,001, $\mathrm{Fe}^{+3}$ de 0,001 e $\mathrm{An}_{32}$ a $\mathrm{An}_{48}$. Plagioclásio observado no $\mathrm{CD}$, bem como no granulito máfico regional, é classificado na figura 16b. De maneira geral, as rochas máficas são mais ricas em $\mathrm{Na}$ e o granulito regional é mais rico em Ca. Além disso, observa-se paralelismo entre os valores de Ca e $\mathrm{Na}$, ocorrendo diminuição discreta nos teores de $\mathrm{Na}$ nas bordas dos grãos e consequente enriquecimento em $\mathrm{Ca}$.

O plagioclásio do granada-hedembergita granulito apresenta textura granoblástica diferente do 
que é observado ao longo do complexo e no granulito regional. Ocorre também inclusos em grãos de granada e, de maneira geral, os grãos inclusos apresentam teores mais baixos de $\mathrm{Na}$ e de An mais altos do que os grãos de plagioclásio na matriz, apesar da variação não ser muito significativa. O plagioclásio incluso apresenta valores apfu de $\mathrm{Na}$ na ordem de 0,07 até 0,08, Ca de 0,90 até 0,92, K de 0,001 até 0,006, $\mathrm{Fe}^{+3}$ abaixo do limite de detecção e teores de An91 até An92. Plagioclásio na matriz apresenta valores apfu de $\mathrm{Na}$ na ordem de 0,10 até 0,13 , Ca de 0,84 até 0,87 e teores de $\mathrm{Fe}^{+3}$ igualmente abaixo do limite de detecção e teores de $\mathrm{An}_{86}$ até $\mathrm{An}_{89}$. Esses valores altos de An no granadahedembergita granulito devem-se ao elevado conteúdo de Ca da rocha. Com exceção dos teores de $\mathrm{Na}$, os valores verificados em plagioclásio desse granulito se assemelham aos valores verificados para as rochas ultramáficas do complexo, mesmo a composição ser exótica a composição das rochas do CD.
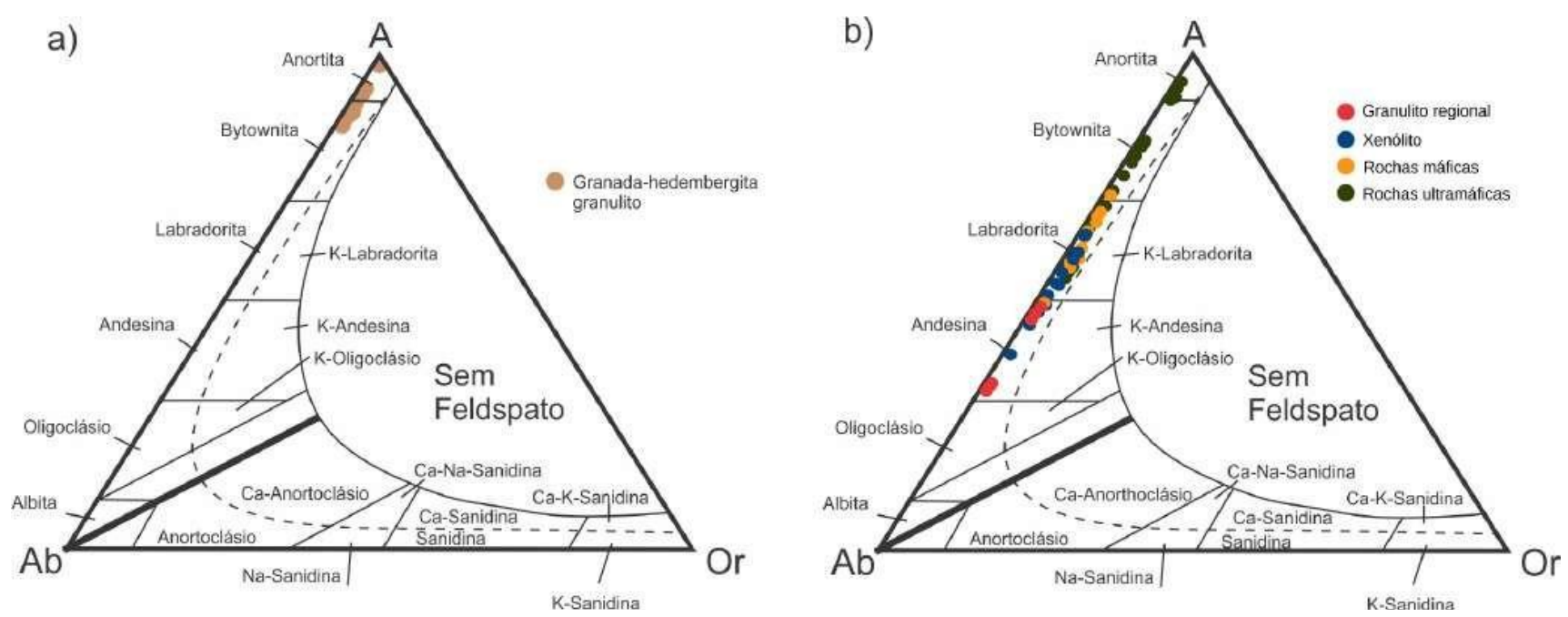

Figura 16: a) Gráfico de caracterização de plagioclásio do granada-hedembergita granulito; e b) Das rochas do Complexo de Damolândia.

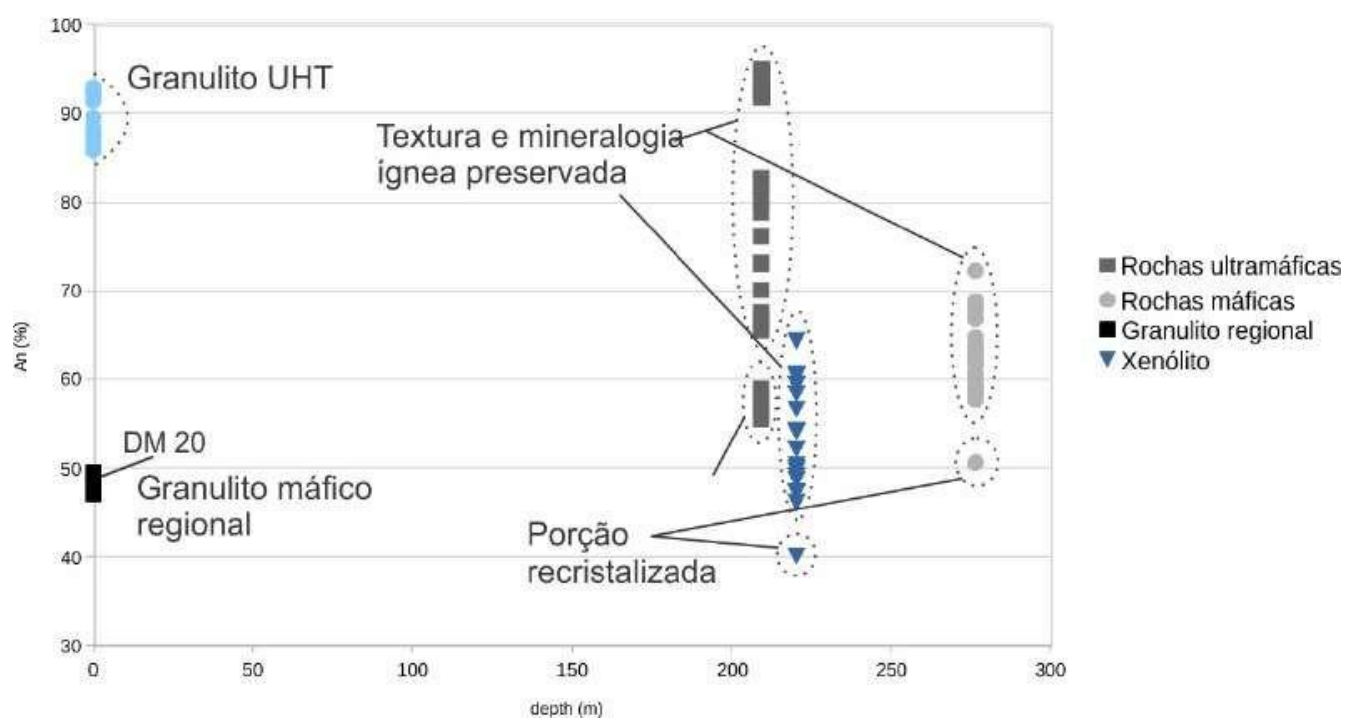

Figura 17: Gráfico da variação dos teores de An (\%) versus a profundidade das rochas analisadas. 
A figura 17 deixa evidente a diferença entre as porções preservas e as porções recristalizadas das rochas do $\mathrm{CD}$, onde as porções preservadas apresentam teores maiores. Fica claro também a diferença entre o granada-hedembergita granulito e o granulito regional analisado, visto que o granulito a dois piroxênios apresenta teores inferiores de An.

Biotita: é observada predominantemente nas porções recristalizadas ou nas áreas próximas às porções recristalizadas. Ocorre como grãos retrometamórficos em meio à matriz recristalizada ou então nas bordas de ortopiroxênio, substituindo-o parcial ou totalmente. Essas observações sugerem que a geração de biotita se deu durante o retrometamorfismo das rochas, juntamente com hornblenda. Não está restrita a uma porção do $\mathrm{CD}$, tendo sido observada ao longo de todas as rochas mas é mais representativa em gabronorito (DM 16), acompanhando a foliação pervasiva e no granulito regional a dois piroxênios (figura 18). Apresenta valores apfu de K na ordem de 1,5 a 1,8, Na de 0,01 a 0,3, Ca de 0 a 0,01, Ba de 0,01 a 0,05, Al (IV) 2,2 a 2,6, Al (VI) de 0,0 a 0,3, Mg de 2,3 a 5,0, Fe de $^{+2}, 5$ a 2,5, Mn de 0 a 0,1, Cr de 0 a 0,04 e Ti de 0,08 a 0,8 .
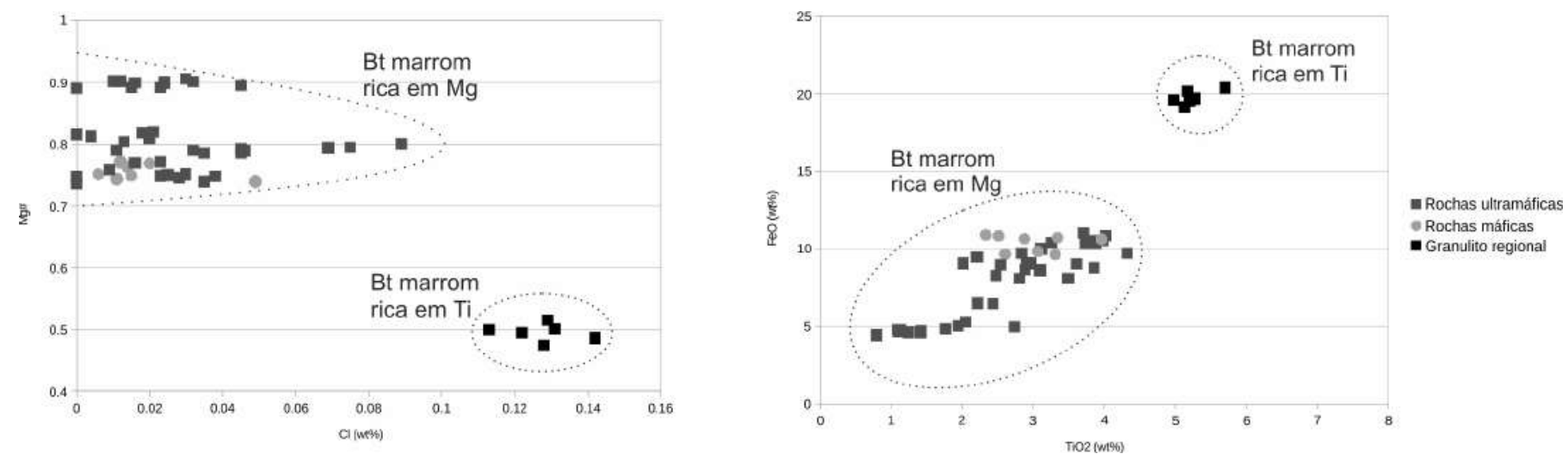

Figura 18: a) Gráfico do $\mathrm{Cl}$ apfu versus $\mathrm{Mg \# ;} \mathrm{e} \mathrm{b)} \mathrm{TiO}_{2}(\mathrm{wt} \%)$ versus $\mathrm{FeO}$ (wt\%), evidenciando a diferença entre biotita observada nas rochas do Complexo de Damolândia e no granulito regional.

Feldspato potássico: o feldspato do CD é observado na porção recristalizada da base da Zona Ultramáfica e topo da Zona Máfica de Base. O xenólito que occore nessa transição apresenta granulação fina e os grãos de feldspato são arredondados. Apresenta valores da molécula de celsiana de $\mathrm{Cel}_{12,6}$ a Cel$_{4,8}$ e valores apfu de K na ordem de 0,765 a 0,841, Na de 0,083 a 0,113, Ba de 0,047 a 0,116, $\mathrm{Ca}$ de 0,001 e 0,005. Os valores expressivos de celsiana permitem que esse feldspato seja classificado como hialofana (figura 19). Além de substituir potássio, Ba também pode substituir cálcio e sódio, o que pode explicar os teores mais baixos de $\mathrm{K}$ e $\mathrm{Ca}$ nesse feldspato potássico. Vale destacar que associados à hialofana, grãos restritos de cianita foram observados, corroborando a mineralogia distinta das demais rochas do CD. Por ocorrerem de maneira restrita e não terem sido verificados grãos representativos, as análises de microssonda não apresentaram fechamento bom e, portanto, os dados 
dos grãos de cianita não serão aqui apresentados nem discutidos.
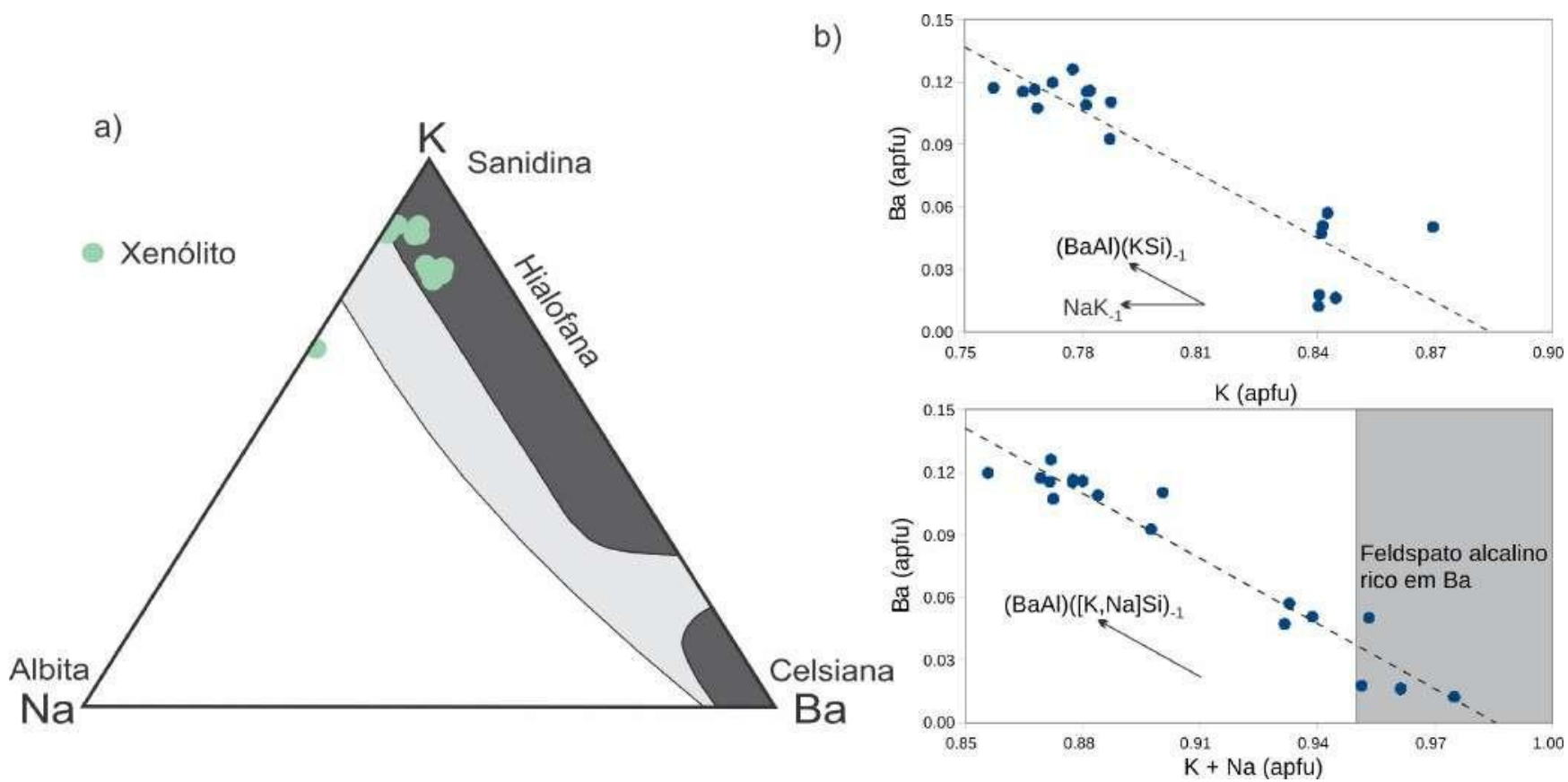

Figura 19: a) Gráfico de caracterização de hialofanas; e b) Vetores de trocas catiônicas observadas em hialofanas do xenólito. Campos cinza no triângulo composicional são estimativas da quantidade de solução sólida em feldspato potássico nas diferentes fácies metamórficas, sendo os limites cinza-escuros referentes à fácies anfibolito inferior a intermediário e a cinza-claro referente à fácies anfibolito superior a granulito (retirado dos limites apresentados em Essene et al. (2005)).

Granada: é observada apenas no granada-hedembergita granulito, não estando presente nas demais rochas do complexo. Foi utilizada, juntamente com plagioclásio e clinopiroxênio (do mesmo granulito) para o modelamento geotermobarométrico do granulito. O granulito regional (DM19) apresenta granulação média a grossa sendo que os cristais apresentam-se xenomórficos. A granada apresenta coloração alaranjada, coroas de reação entre os grãos de granada e hedembergita (figura 5n, o e p), bem como simplectitos entre plagioclásio e granada. A granada desse granulito é rica na molécula de grossulária (40,7\% a 51,4\%), com proporções intermediárias de andradita (27,9\% a 42,2\%), menores de almandina $(13,1 \%$ a $15,4 \%)$ e baixas de espessartina $(0,770 \%$ a $1,005 \%)$, piropo $(0,176 \%$ a $0,392 \%$ ) e uvarovita ( 0 a $0,195 \%)$. O perfil composicional da figura 20 evidencia leve enriquecimento de almandina e andradita e empobrecimento também discreto de grossulária nas bordas. Os tores de espessartina, piropo e uvarovita mantém-se constantes ao longo do perfil. Observam-se também valores apfu de $\mathrm{Fe}^{+2}$ na ordem de 0,38 a 0,64, $\mathrm{Fe}^{+3}$ de 0,632 a 0,992, Mn de 0,024 a 0,030, Ca de 2,45 a 2,63, Mg de 0,005 a 0,012, Ti de 0,034 a 0,051, Al de 0,940 a 1,122. A figura 20 evidencia empobrecimento discreto de $\mathrm{Fe}^{+2}$ e $\mathrm{Ca}$ nas bordas, leve enriquecimento de Ti no núcleo. O Al permanece relativamente constante ao longo do perfil composicional, apresentando um leve enriquecimento nas bordas e $\mathrm{Mg}$ e Mn também se mantém constantes. A figura 20 evidencia também a ausência de distribuição 
concêntrica dos elementos na granada.

A figura 21 deixa evidente a diferença composicional entre o núcleo e a borda da granada do granada-hedembergita granulito. $\mathrm{O}$ núcleo da granada é mais enriquecido na molécula de andradita enquanto a borda é mais enriquecida em grossulária. Essa variação reflete os valores de pressão e temperatura obtidos nos cálculos geotermobarométricos que serão detalhados mais à frente.
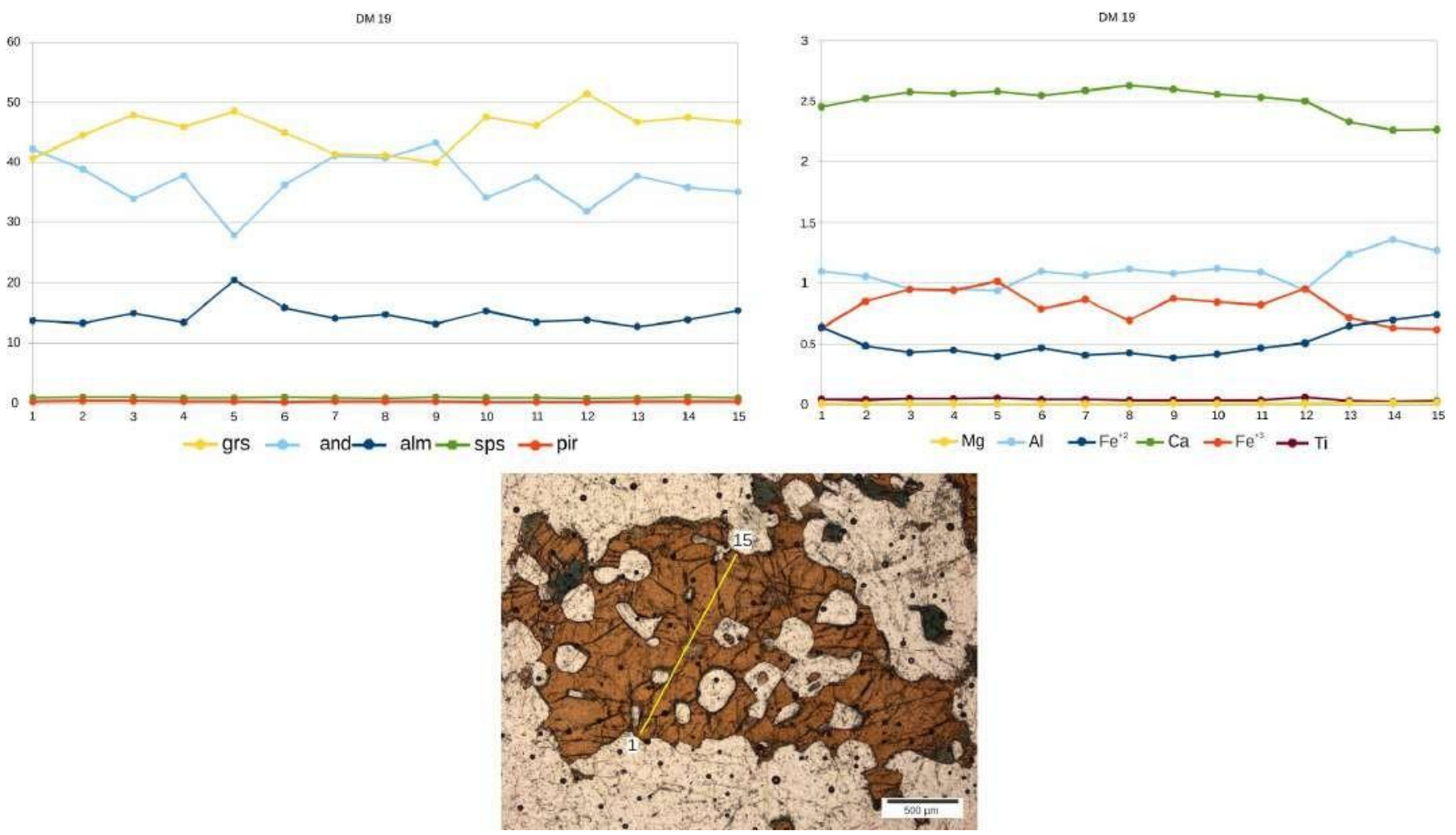

Figura 20: Perfil composicional de granada do granada-hedembergita granulito (amostra DM19) analisado.

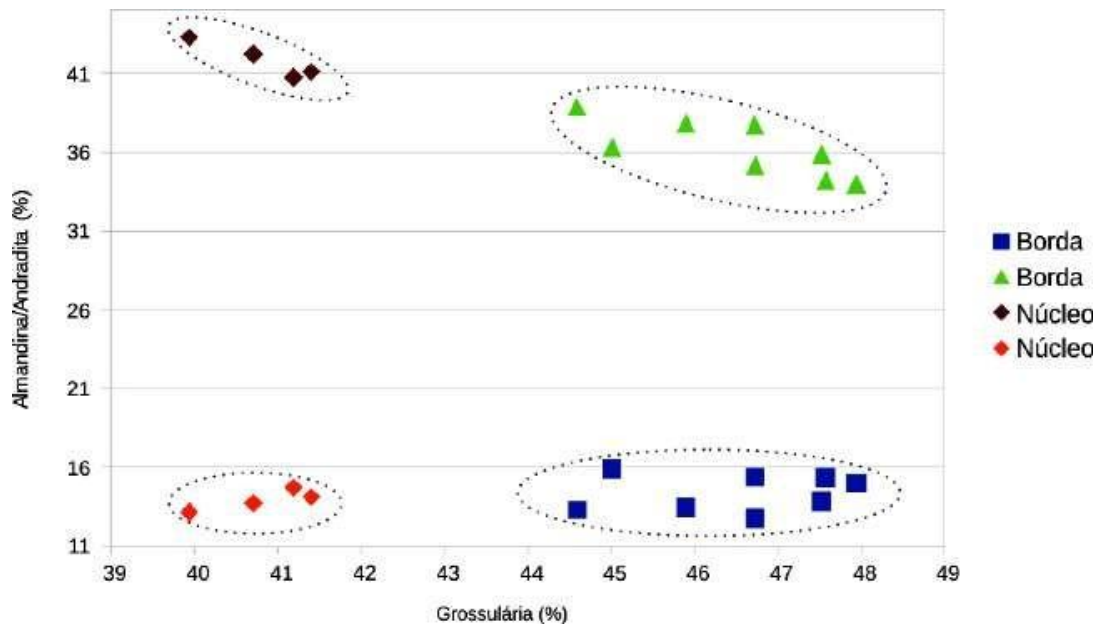

Figura 21: Gráfico dos teores da molécula de grossulária (\%) versus as moléculas de almandina e andradita (\%). 


\subsection{Litogeoquímica}

Listadas na tabela 1 , encontram-se as composições de rocha total para o CD e a amostra de granulito regional descrita. As rochas máficas e ultramáficas são cumuláticas e, portanto, tanto os elementos maiores quanto menores devem ser controlados pelo tipo predominante de mineral cumulático da rocha. Os gráficos mostrados na figura 22, dos principais óxidos de elementos maiores versus $\mathrm{MgO}$ evidenciam a predominância de cumulatos de olivina, ortopiroxênio e, de maneira mais restrita, clinopiroxênio, bem como de plagioclásio intercumulático. Isso é corroborado pela descrição quando se compara esses gráficos com a descrição dos minerais cumuláticos na seção anterior. Por não

apresentarem valores significativos de LOI, as análises não foram recalculadas para base anídrica, já que quando se compara as LOI das rochas da Zona Máfica e Ultramáfica, não se observa variação significativa ( $2 \mathrm{wt} \%$ em harzburgito e 0,5 a $1 \mathrm{wt} \%$ em ortopiroxenito e olivina ortopiroxenito).

Harzburgito apresenta valor de $\mathrm{MgO}$ em wt\% de 36,27, consistente com a presença de olivina como a principal fase cumulática dessas rochas. Teores dos elementos maiores como $\mathrm{SiO}_{2}, \mathrm{CaO}_{2} \mathrm{Al}_{2} \mathrm{O}_{3}$, $\mathrm{NaO}$ e $\mathrm{K}_{2} \mathrm{O}$ nestas rochas sugerem a presença de minerais como clinopiroxênio e plagioclásio como fases cumuláticas, não sendo controladas apenas por olivina e ortopiroxênio. Teores de $\mathrm{Cr}_{2} \mathrm{O}_{3}$ variando de 0,14 a 0,38 wt\% são consistentes com a ocorrência de cromita cumulática nesse harzburgito. Valores baixos de $\mathrm{S}$, variando de 0,11 a $0,91 \mathrm{wt} \%$ sugerem que o teor de Ni dessas rochas é, ao menos em parte, controlado pela olivina cumulática.

Ortopiroxenito e olivina ortopiroxenito apresentam teores de $\mathrm{MgO}$ de 23,98 wt\% e 17,12 wt\%, respectivamente. Teores de $\mathrm{CaO}$ são de 3,45 e 11,27 wt\% respectivamente, indicativo da presença de clinopiroxênio cumulático e plagioclásio intercumulático. Valores de $\mathrm{Cr}_{2} \mathrm{O}_{3}$ entre 0,299 e 0,136 são consistentes com a ocorrência de cromita cumulática. Esses valores inferiores aos observados em harzburgito indicam ocorrência mais restrita de cromita em ortopiroxenito e olivina ortopiroxenito, o que de fato pôde ser observado em lâmina delgada. Teores mais elevados de $\mathrm{Cu}(581 \mathrm{a} 703,5 \mathrm{ppm}), \mathrm{Ni}$ (1772 a 2078 ppm), Au (13,4 a 14,4 ppb) e Bi (4,3 a 5,1 ppm) nessas rochas são compatíveis com a ocorrência representativa da fase sulfetada.

Rochas gabróicas apresentam valores baixos de $\mathrm{MgO}$, variando de 7,22 a 10,11 wt\%. Valores de $\mathrm{Al}_{2} \mathrm{O}_{3}$ e $\mathrm{Na}_{2} \mathrm{O}$ abaixo da tie-line do $\mathrm{Pl}-\mathrm{Opx}$ podem ser resultado da presença de flogopita ou de alteração das fases cumuláticas (figura 22), o que é observado principalmente nas porções recristalizadas das rochas. Valores mais elevados de $\mathrm{TiO}_{2}(0,58$ a 0,99 wt\%) são compatíveis com a presença de óxidos de Fe-Ti acessórios, como ilmenita e rutilo, que foram de fato observados como minerais acessórios ao longo do complexo. 
Tabela 1: análises de rocha total do Complexo de Damolândia. Gbr = gabro, Nrt = norito, Opxt = ortopiroxenito, Hzb = harzburgito, Gbrnrt = gabronorito e GR = granulito regional.

\begin{tabular}{|c|c|c|c|c|c|c|c|c|c|c|}
\hline Sample & DM01 & DM02 & DM04 & DM07 & DM10 & DM12 & DM14 & DM-16 & DM-18 & DM-20 \\
\hline Depth & 283 & 282.4 & 276.45 & 217.9 & 209.45 & 166.35 & 102.4 & 68.25 & 0 & 0 \\
\hline Rock & Gbr & $\mathrm{Gbr}$ & $\mathrm{Nrt}$ & Opxt & Pxt & $\mathrm{Hzb}$ & Opxt & Gbrnrt & GR & GR \\
\hline $\mathrm{SiO}_{2}(\mathrm{wt} \%)$ & 48.85 & 50.31 & 50.49 & 52.79 & 50.81 & 40.29 & 51.73 & 47.92 & 55.63 & 48.24 \\
\hline $\mathrm{Al}_{2} \mathrm{O}_{3}(\mathrm{wt} \%)$ & 15.94 & 19.25 & 12.84 & 4.78 & 7.20 & 1.50 & 3.23 & 16.72 & 22.54 & 14.34 \\
\hline $\mathrm{Fe}_{2} \mathrm{O}_{3}(\mathrm{wt} \%)$ & 10.60 & 7.02 & 11.32 & 12.70 & 10.99 & 17.71 & 13.61 & 12.38 & 4.31 & 13.76 \\
\hline $\mathrm{CaO}(\mathrm{wt} \%)$ & 9.40 & 10.69 & 6.84 & 3.45 & 11.27 & 0.14 & 1.45 & 6.53 & 7.49 & 11.19 \\
\hline $\mathrm{MgO}(\mathrm{wt} \%)$ & 10.11 & 7.22 & 13.80 & 23.98 & 17.12 & 36.72 & 27.11 & 3.47 & 2.48 & 6.86 \\
\hline $\mathrm{Na}_{2} \mathrm{O}(\mathrm{wt} \%)$ & 1.84 & 2.52 & 1.44 & 0.15 & 0.54 & 0.02 & 0.09 & 3.27 & 3.98 & 2.73 \\
\hline $\mathrm{K}_{2} \mathrm{O}(w t \%)$ & 0.56 & 0.62 & 0.49 & 0.06 & 0.07 & 0.04 & 0.03 & 4.08 & 0.63 & 0.23 \\
\hline $\mathrm{Cr}_{2} \mathrm{O}_{3}(\mathrm{wt} \%)$ & 0.02 & 0.01 & 0.06 & 0.30 & 0.14 & 0.38 & 0.18 & $<0.002$ & 0.01 & 0.02 \\
\hline $\mathrm{TiO}_{2}(\mathrm{wt} \%)$ & 0.99 & 0.58 & 0.54 & 0.28 & 0.51 & 0.05 & 0.18 & 2.68 & 1.09 & 1.68 \\
\hline $\mathrm{MnO}(\mathrm{wt} \%)$ & 0.15 & 0.11 & 0.18 & 0.19 & 0.20 & 0.20 & 0.20 & 0.16 & 0.05 & 0.22 \\
\hline $\mathrm{P}_{2} \mathrm{O}_{5}(\mathrm{wt} \%)$ & $<0.01$ & 0.02 & $<0.01$ & $<0.01$ & 0.03 & 0.02 & $<0.01$ & 1.19 & 0.36 & 0.13 \\
\hline LOI (\%) & 1.10 & 1.40 & 1.60 & 0.50 & 0.60 & 2.10 & 1.40 & 1.00 & 1.00 & 0.10 \\
\hline Total & 99.56 & 99.75 & 99.60 & 99.18 & 99.48 & 99.17 & 99.21 & 99.40 & 99.57 & 99.50 \\
\hline $\mathrm{S}(\%)$ & 0.12 & 0.12 & 0.20 & 0.91 & 0.24 & 0.11 & 0.77 & 0.13 & 0.13 & - \\
\hline $\mathrm{Ba}(\mathrm{ppm})$ & 393.00 & 328.00 & 237.00 & 14.00 & 40.00 & 6.00 & 9.00 & $2,040.00$ & 413.00 & 36.00 \\
\hline $\mathrm{Ce}(\mathrm{ppm})$ & 15.60 & 17.90 & 11.60 & 3.20 & 20.70 & 0.50 & 3.60 & 208.00 & 55.20 & 15.40 \\
\hline Cs (ppm) & 0.20 & 0.10 & 0.40 & 0.20 & 0.10 & $<0.1$ & $<0.1$ & 0.60 & 0.20 & - \\
\hline Dy (ppm) & 1.94 & 2.14 & 1.42 & 0.71 & 4.00 & $<0.05$ & 0.49 & 10.39 & 2.44 & 5.17 \\
\hline $\operatorname{Er}(\mathrm{ppm})$ & 1.09 & 1.18 & 0.91 & 0.53 & 2.17 & $<0.03$ & 0.32 & 5.19 & 1.06 & 3.52 \\
\hline Eu (ppm) & 0.78 & 0.98 & 0.54 & 0.16 & 1.01 & 0.03 & 0.10 & 4.10 & 2.53 & 1.23 \\
\hline $\mathrm{Ga}(\mathrm{ppm})$ & 14.60 & 13.70 & 11.20 & 5.90 & 10.10 & 5.50 & 4.90 & 24.70 & 30.00 & 18.10 \\
\hline Gd (ppm) & 2.36 & 2.49 & 1.51 & 0.74 & 4.49 & 0.06 & 0.42 & 15.12 & 3.59 & 4.60 \\
\hline $\mathrm{Hf}(\mathrm{ppm})$ & 1.50 & 1.50 & 1.10 & 0.50 & 2.40 & $<0.1$ & 0.40 & 18.20 & 24.80 & 2.50 \\
\hline Ho (ppm) & 0.37 & 0.40 & 0.31 & 0.18 & 0.80 & $<0.02$ & 0.11 & 1.90 & 0.37 & 1.30 \\
\hline La (ppm) & 7.10 & 8.50 & 5.60 & 1.10 & 6.90 & 0.50 & 1.60 & 91.40 & 27.10 & 5.80 \\
\hline Lu (ppm) & 0.17 & 0.14 & 0.15 & 0.09 & 0.28 & $<0.01$ & 0.06 & 0.67 & 0.17 & 0.52 \\
\hline Mo (ppm) & $<0.1$ & $<0.1$ & $<0.1$ & $<0.1$ & $<0.1$ & $<0.1$ & $<0.1$ & 0.70 & & \\
\hline $\mathrm{Nb}$ (ppm) & 1.80 & 0.80 & 0.70 & 0.10 & 0.20 & $<0.1$ & 0.20 & 33.90 & 8.40 & 3.60 \\
\hline $\mathrm{Nd}(\mathrm{ppm})$ & 9.80 & 10.60 & 6.70 & 2.20 & 17.90 & $<0.3$ & 2.10 & 107.60 & 24.10 & 11.30 \\
\hline $\operatorname{Pr}(\mathrm{ppm})$ & 1.98 & 2.34 & 1.55 & 0.39 & 3.32 & 0.02 & 0.40 & 26.15 & 5.93 & 2.26 \\
\hline $\mathrm{Rb}(\mathrm{ppm})$ & 7.70 & 6.10 & 9.50 & 3.60 & 1.70 & 1.60 & 1.70 & 148.70 & 4.40 & 1.60 \\
\hline Sc (ppm) & 31.00 & 26.00 & 30.00 & 33.00 & 56.00 & 4.00 & 24.00 & 22.00 & 6.00 & 52.00 \\
\hline Sm (ppm) & 2.32 & 2.44 & 1.46 & 0.56 & 4.58 & 0.10 & 0.42 & 18.74 & 4.03 & 3.58 \\
\hline Sn (ppm) & 2.00 & $<1$ & $<1$ & 1.00 & 2.00 & $<1$ & 4.00 & 3.00 & - & 1.00 \\
\hline $\mathrm{Sr}(\mathrm{ppm})$ & 559.20 & 725.00 & 405.10 & 14.80 & 90.30 & 2.00 & 5.40 & 592.30 & $1,187.80$ & 153.80 \\
\hline $\mathrm{Ta}(\mathrm{ppm})$ & 0.40 & 0.20 & 0.20 & $<0.1$ & 0.20 & $<0.1$ & 0.10 & 1.30 & 0.30 & 0.20 \\
\hline $\mathrm{Tb}$ (ppm) & 0.37 & 0.37 & 0.24 & 0.12 & 0.71 & $<0.01$ & 0.08 & 2.11 & 0.44 & 0.93 \\
\hline Th (ppm) & 0.40 & $<0.2$ & 0.70 & 0.40 & 0.60 & $<0.2$ & 0.40 & 2.90 & 0.30 & - \\
\hline $\mathrm{Tm}(\mathrm{ppm})$ & 0.15 & 0.16 & 0.13 & 0.09 & 0.31 & $<0.01$ & 0.05 & 0.72 & 0.15 & 0.53 \\
\hline $\mathrm{U}(\mathrm{ppm})$ & 0.30 & $<0.1$ & 0.20 & 0.20 & 0.20 & $<0.1$ & 0.20 & 0.40 & 0.20 & - \\
\hline V (ppm) & 277.00 & 147.00 & 166.00 & 150.00 & 243.00 & 30.00 & 99.00 & 165.00 & 63.00 & 376.00 \\
\hline W (ppm) & 167.40 & 135.90 & 216.50 & 133.00 & 223.20 & 86.00 & 127.50 & 110.00 & 143.80 & 172.90 \\
\hline $\mathrm{Y}(\mathrm{ppm})$ & 10.40 & 9.20 & 7.80 & 4.40 & 20.10 & 0.30 & 2.70 & 52.40 & 11.10 & 31.20 \\
\hline $\mathrm{Yb}(\mathrm{ppm})$ & 1.11 & 0.97 & 0.95 & 0.56 & 1.85 & 0.06 & 0.42 & 4.46 & 0.79 & 3.47 \\
\hline $\mathrm{Zr}(\mathrm{ppm})$ & 41.10 & 33.10 & 27.20 & 12.60 & 65.00 & 1.10 & 12.10 & 851.60 & $1,032.60$ & 83.60 \\
\hline Co (ppm) & 72.20 & 51.50 & 89.00 & 140.10 & 100.10 & 209.30 & 147.60 & 43.60 & 35.70 & 66.30 \\
\hline $\mathrm{Cu}(\mathrm{ppm})$ & 37.70 & 43.00 & 76.90 & 703.50 & 125.60 & 102.60 & 581.00 & 36.10 & 85.80 & 16.60 \\
\hline $\mathrm{Ni}(\mathrm{ppm})$ & 118.00 & 96.00 & 291.00 & $2,078.00$ & 606.00 & $1,218.00$ & $1,772.00$ & 21.00 & 206.00 & 37.00 \\
\hline $\mathrm{Pb}(\mathrm{ppm})$ & 4.40 & 4.70 & 4.20 & 24.30 & 1.80 & 0.60 & 11.70 & 1.10 & 1.50 & - \\
\hline $\mathrm{Zn}(\mathrm{ppm})$ & 9.00 & 12.00 & 11.00 & 3.00 & 6.00 & 33.00 & 16.00 & 95.00 & - & - \\
\hline As (ppm) & 1.60 & 0.60 & 1.20 & $<0.5$ & 0.60 & 0.60 & 2.20 & $<0.5$ & - & - \\
\hline $\mathrm{Bi}(\mathrm{ppm})$ & $<0.1$ & $<0.1$ & $<0.1$ & 5.10 & $<0.1$ & $<0.1$ & 4.30 & $<0.1$ & - & - \\
\hline
\end{tabular}

Valores de $\mathrm{K}_{2} \mathrm{O}$ acima da tie-line Pl-Opx podem ser indicativos da ocorrência de feldspato potássico e flogopita (de maneira restrita) ou de alteração da rocha. Os valores de $\mathrm{Fe}_{2} \mathrm{O}_{3}$ acima da tieline do Pl-Opx sugerem a presença de biotita, dos sulfetos disseminados ou ainda, alteração da rocha. $\mathrm{O}$ gráfico $\mathrm{CaO}-\mathrm{Al}_{2} \mathrm{O}_{3}$ (figura 23) é compatível com rochas gabróicas fracionadas a partir da cristalização de $\mathrm{Pl}+$ Opx na base e $\mathrm{Pl}+\mathrm{Opx}+\mathrm{Cpx}$ em direção ao topo dessas rochas. Teores significativos de $\mathrm{Ba}$ (237 a 393 ppm) são compatíveis com a presença de hialofana verificada no xenólito que ocorre na 
transição entre as rochas máficas e ultramáficas, conforme descrito na seção anterior.

Norito apresenta teores de $\mathrm{MgO}$ na ordem de 13,80 wt\%. Valores de $\mathrm{Al}_{2} \mathrm{O}_{3}$ e $\mathrm{CaO}$ indicam a presença de plagioclásio e clinopiroxênio de forma mais restrita do que em gabro. Valores de $\mathrm{K}_{2} \mathrm{O}$ na ordem de 0,49 wt\% e $\mathrm{Na}_{2} \mathrm{O}$ na ordem de 1,44 wt\% são indicativos da presença de feldspato potássico ou de alteração das fases cumuláticas predominantes. Valores de $\mathrm{Fe}_{2} \mathrm{O}_{3}$ observados acima da tie-line $\mathrm{Pl}$ Opx e Opx-Ol sugerem a ocorrência de biotita.
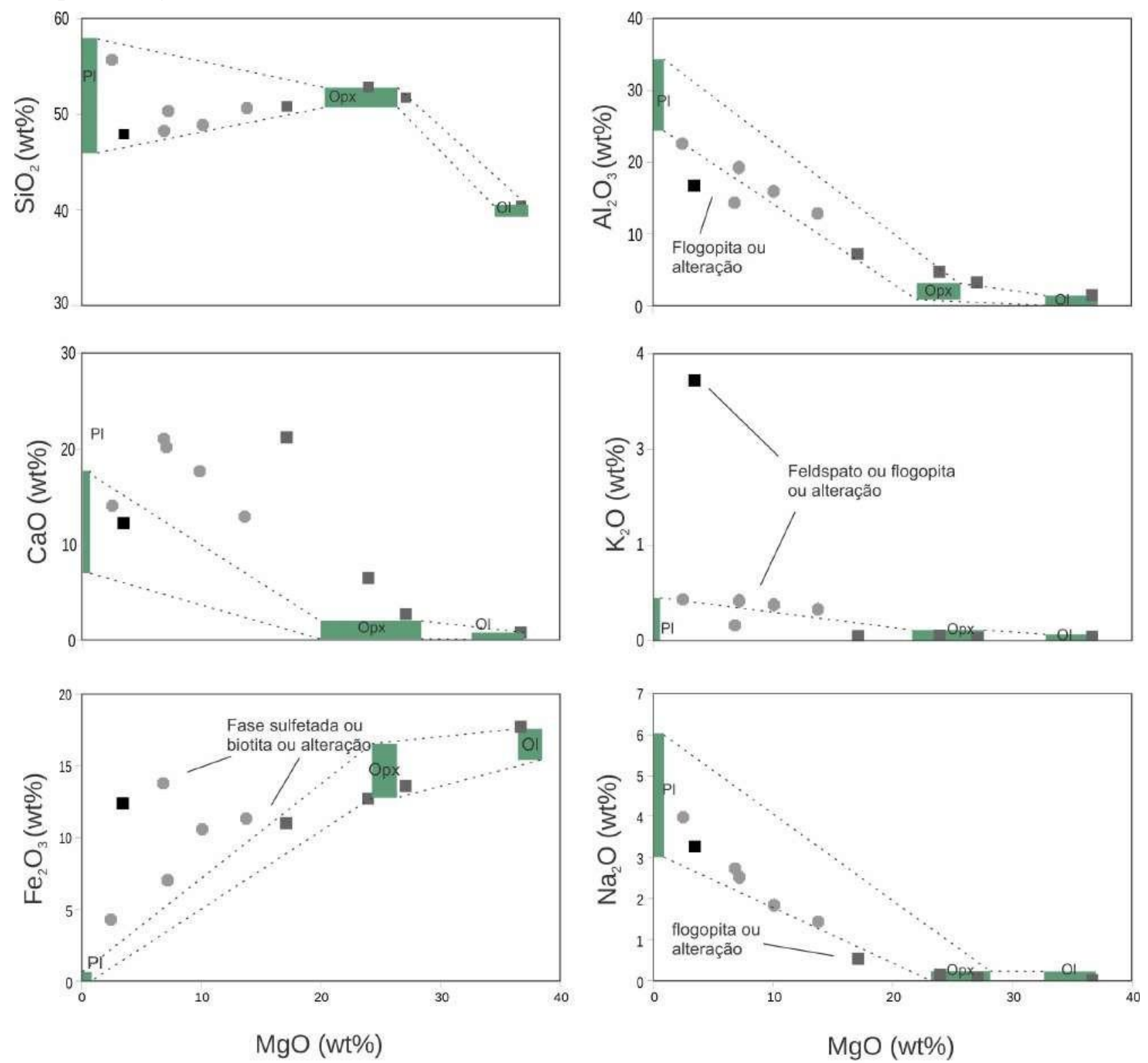

Rochas máficas

Rochas ultramáficas

Granulito regional

Figura 22: Gráficos de $\mathrm{MgO}$ versus o conteúdo dos elementos maiores para as rochas do Complexo de Damolândia. Os dados aqui apresentados foram retirados das análises geoquímicas de rocha total apresentados na tabela 1. Os campos utilizados para as delimitação das fases cumuláticas predominantes e das tie-lines foram elaborados a partir de média dos valores para os respectivos minerais observados no Complexo de Damolândia. 
A amostra DM 18 é também um gabronorito tardio coletado em afloramento, sendo integrante da Zona Máfica de Topo. É a rocha que apresenta valores que mais destoam das demais rochas do CD. Possui valores mais baixos de $\mathrm{MgO}$ (3,47 wt \%), $\mathrm{Al}_{2} \mathrm{O}_{3}$ de 16,72 wt\%, $\mathrm{Na}_{2} \mathrm{O}$ de 3,27 wt $\%$ e $\mathrm{TiO}_{2}$ de 2,68 wt\%, indicativo de óxidos de Fe-Ti como fases acessórias. Apresenta valores superiores de Ba de 2040 ppm, $\mathrm{Nb}$ de 33,9 ppm, Nd de 107,6 ppm, Rb de 148,7 ppm, Zr de 851,6 ppm e $\mathrm{P}{ }_{2} \mathrm{O}_{5}$ de 1,19. Teores de incompatíveis (HFSE e LILE) mais elevados no caso desses granulitos são possíveis indicativos de geração dessas rochas a partir de manto metassomatizado ou possível metamorfismo subsequente extensivo dessas rochas e da presença de apatita como fase acessória. O granulito regional (DM20) analisado possui, de maneira geral, valores mais baixos que as demais rochas do $\mathrm{CD}$, sendo $\mathrm{MgO}$ de $6,88 \mathrm{wt} \%, \mathrm{Al}_{2} \mathrm{O}_{3}$ de 14,34 wt $\%, \mathrm{~K}_{2} \mathrm{O}$ de 0,23 wt $\%, \mathrm{Na}_{2} \mathrm{O}$ de 2,73 wt $\%$ e $\mathrm{TiO}_{2}$ de 1,68 wt $\%$. Apresenta valores de $\mathrm{Ba}$ de 36 ppm, $\mathrm{Nb}$ de 3,6 ppm, $\mathrm{Nd}$ de 11,3 ppm, $\mathrm{Rb}$ de 1,6 ppm, $\mathrm{Zr}$ de 83,6 ppm e $\mathrm{P}_{2} \mathrm{O}_{5}$ de $0,13 \mathrm{wt} \%$.
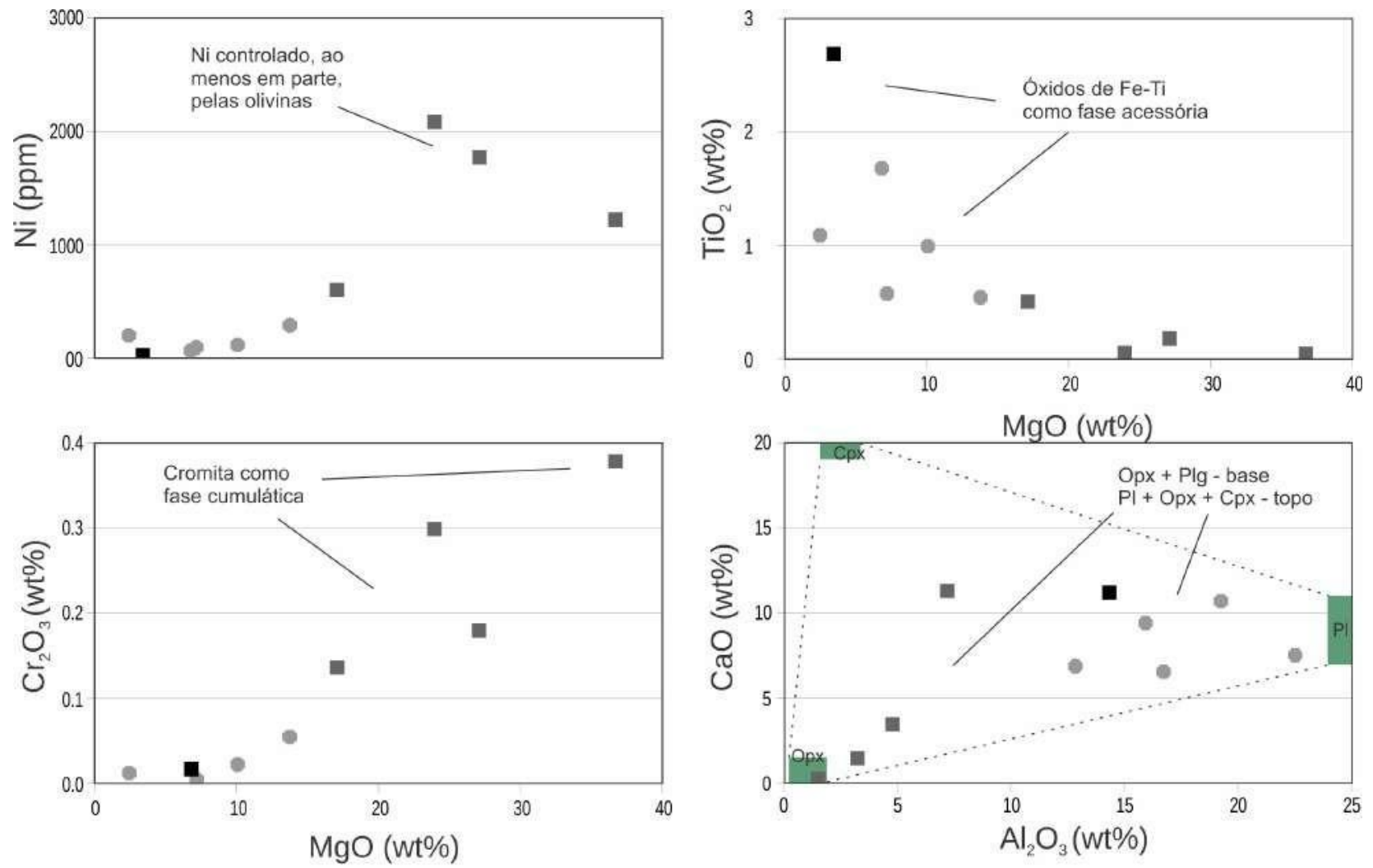

Rochas máficas

- Rochas ultramáficas

- Granulito regional

Figura 23: $\mathrm{MgO}$ versus o conteúdo dos elementos menores e gráficos de $\mathrm{Al}_{2} \mathrm{O}_{3}-\mathrm{CaO}$ para as rochas do Complexo de Damolândia. Os dados aqui apresentados foram retirados das análises geoquímicas de rocha total apresentados na tabela 1. Os campos utilizados para as delimitação das fases cumuláticas predominantes e das tie-lines foram delimitados a partir de média dos valores para os respectivos minerais observados no Complexo de Damolândia. 


\subsection{Elementos traço}

Rochas do CD apresentam valores relativamente baixos de elementos incompatíveis, o que é coerente com rochas compostas de cumulatos de olivina e piroxênios e plagioclásio intersticial. A variação dos conteúdos de elementos incompatíveis entre as rochas do CD (figura 24) é resultado da combinação dos efeitos das associações variáveis dos minerais cumuláticos, da variação do fracionamento do magma parental e eventual variação da quantidade de líquido intercúmulus aprisionado (Barnes, 1986; Ferreira e Filho et al., 1998).

a)

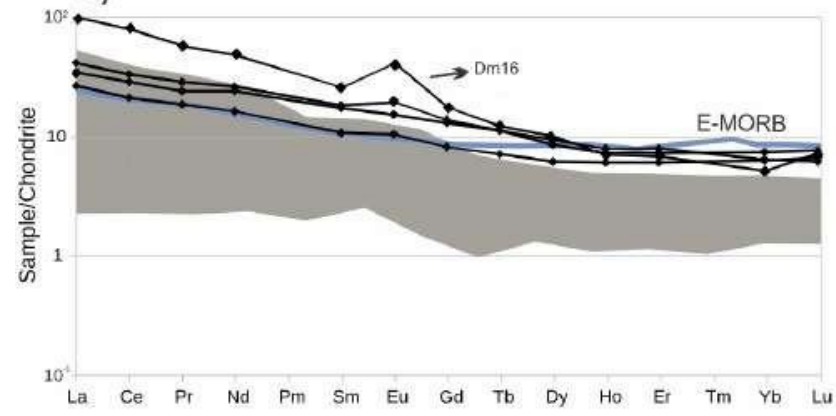

c)

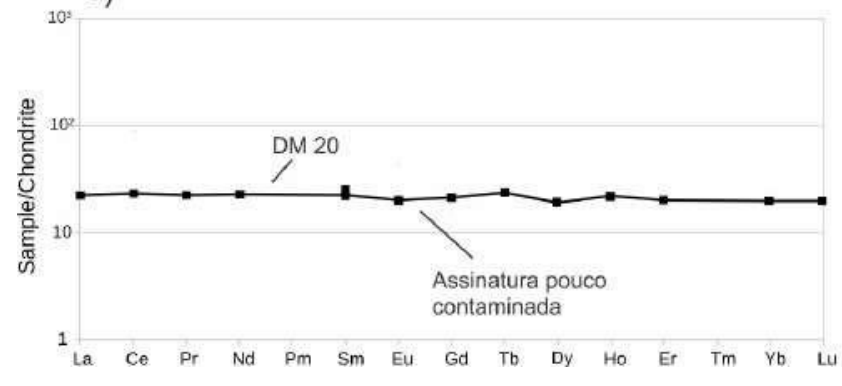

b)

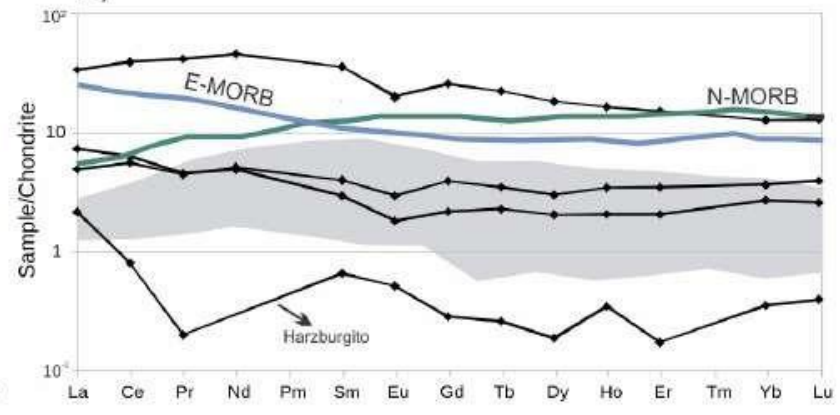

Figura 24: a) Perfis de elementos terras-raras (REE) das rochas do máficas Complexo de Damolândia normalizados pelo condrito; b) Rochas ultramáficas; c) Granulito regional. Os valores foram comparados aos de Americano do Brasil (Mota e Silva, 2009; Mota e Silva et al., 2011). Os dados foram normalizados a partir da tabela 1. Os valores padrões dos condritos normalizados foram retirados de Sun \& McDonough (1989).

O gabro apresenta discreto enriquecimento em LREE (figura 24a) e empobrecimento em HREE e anomalia nula a positiva de Eu (indicativo de cristalização de plagioclásio cumulático variável). Rochas gabróicas apresentam desnível positivo para LREE, indicando enriquecimento progressivo em direção a LREE e desnível discreto a positivo para HREE, bem como distinta anomalia positiva de Eu. A amostra DM16 (gabronorito tardio) apresenta desnível acentuado para LREE, os menores valores observados para os HREE nas rochas máficas e a anomalia positiva de $\mathrm{Eu}$.

Padrões de REE das rochas ultramáficas apresentam-se quase paralelos (figura 24b), o que reflete o comportamento de rochas compostas principalmene por olivina, piroxênios e plagioclásio. As rochas apresentam assinaturas pouco contaminadas. Apresentam também, de maneira geral, valores que plotam abaixo de valores do N-MORB (manto depletado), o que reflete a natureza primitiva dessas 
rochas. Além disso, apresentam característica anomalia negativa de Eu. De maneira geral, o enriquecimento em REE com a estratigrafia pode ser resultado de fracionamento ascendente do magma parental.

O granulito regional DM 20 analisado é a rocha com assinatura menos contaminada (figura 24c).

a)

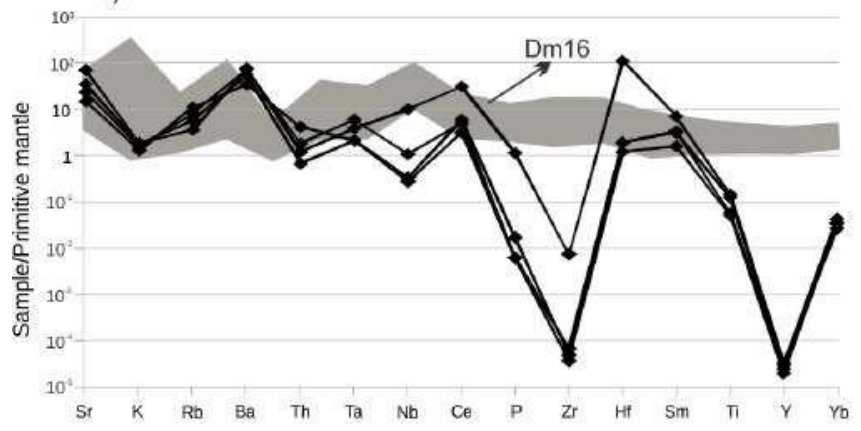

c)

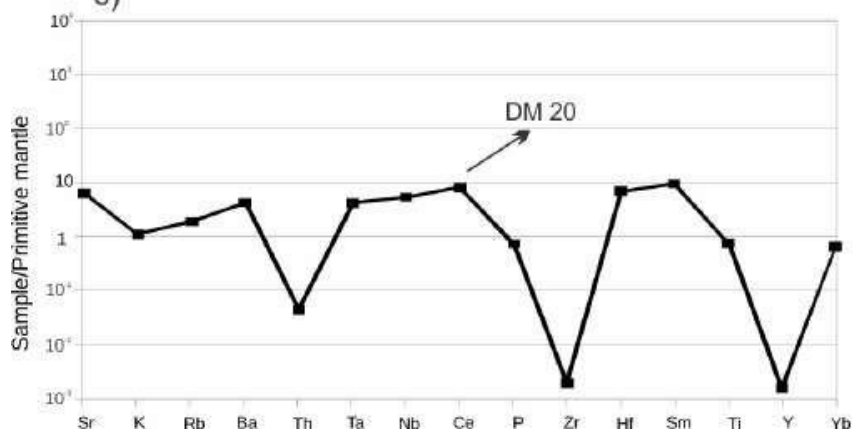

b)

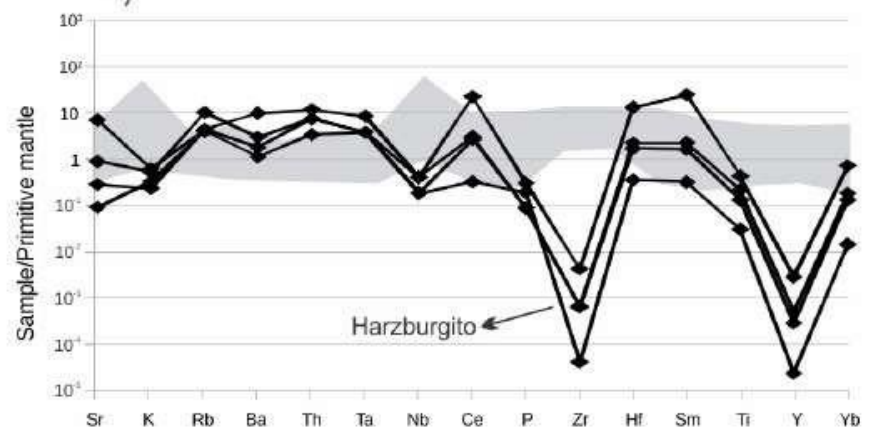

$\longrightarrow$ Granulito regional do Complexo Anápolis-Itauçu Rochas máfica-ultramáficas do Complexo de Damolândia Sequência norte do Complexo Americano do Brasil Sequência sul do Complexo Americano do Brasil

Figura 25: a) Perfis dos elementos traço normalizados pelo manto primitivo das amostras das rochas máficas do Complexo de Damolândia; b) Rochas ultramáficas; c) Granulito regional. Os valores foram comparados aos do Complexo Americano do Brasil (Mota e Silva, 2009; Mota e Silva et al., 2011). Os dados foram normalizados a partir da tabela 1 e os valores de normalização do manto primitivo são de Sun \& McDonough (1989).

A comparação tanto dos teores de REE quanto de elementos traço (figura 25) com os valores publicados por Mota e Silva (2009) revela que os valores de REE se assemelham aos valores da sequência sul do Complexo Americano do Brasil (CAB). As rochas do CD apresentam teores enriquecidos de HREE em relação às rochas máfico-ultramáficas da sequência sul do CAB. Quando comparados aos dados do $\mathrm{CAB}$ os valores dos elementos traço do Complexo de Damolândia apresentam valores inferiores, o que sugere uma natureza menos fracionada. A anomalia de Ba alta é referente à amostra DM18, que é um gabronorito tardio da Zona Máfica de Topo. O CD se aproxima mais de E-MORB, enquanto o CAB é toleítico tipo N-MORB. Isso evidencia contribuição do manto metassomatizado no CD. Enquanto o CAB é de possível ambiente back-arc como definido por Mota e Silva (2009), o CD representa o típico exemplo de intrusão sinorogênica, concomitante à colisão e ao metamorfismo. 


\section{Geotermobarometria do granada-hedembergita granulito}

Termobarometria é, por definição, a determinação das condições P-T de formação de determinada associação mineral (Powell et al., 2008). Partindo do pressuposto de que os cálculos termobarométricos são realizados em equilíbrio termodinâmico, deve-se supor de maneira semelhante que a associação mineral utilizada nos cálculos esteve em equilíbrio (mesmo que em parte) durante o caminho P-T percorrido pela rocha em questão.

Segundo Powell \& Holland (2008), considera-se termobarometria convencional como sendo aquela que inclui todos os métodos termobarométricos que se baseiam em reações balanceadas entre os membros finais das fases em equilíbrio. Em granulitos e rochas UHT, cálculos termobarométricos apresentam uma dificuldade a mais, tanto pelo papel que a fusão parcial destas rochas desempenha quanto pelo fato que a difusão, processo físico fortemente controlado pela temperatura, torna-se notavelmente mais pronunciada quando a rocha alcança fácies granulito e condições UHT (Powell \& Holland, 2008).

Uma das maneiras de obter bons resultados em um cálculo P-T é com programas que utilizam banco de dados termodinâmicos internamente consistentes, como THERMOCALC (Holland \& Powell, 2011), PTMafic (Soto \& Soto, 1995) ou TWEEQU (Berman, 1988), entre outros. Dentre os programas utilizados nos cálculos aqui descritos do granada-hedembergita granulito, cita-se o supracitado THERMOCALC v3.33 e o LibreOffice Calc v5.0, sendo este último muito utilizado nos cálculos utilizando cálculos de geotermobarômetros convencionais. Juntamente com os softwares de cálculos geotermobarométricos já mencionados, o programa 'a-X' v2.2 (Holland \& Powell, 2011), programa baseado no cálculo das atividades dos membros finais das fases minerais envolvidas nas reações termobarométricas, foi também utilizado durante os cálculos.

THERMOCALC é um software que, de maneira geral, utiliza um conjunto de reações que agregam e combinam informações de todos os membros finais de minerais envolvidos nas reações de um determinado sistema químico. Este programa realiza o cálculo de modo a diminuir os erros associados aos valores finais, onde o erro associado aos cálculos feitos pelo programa é efetuado por meio do deslocamento desses valores dentro de suas barras de erro até que se define uma elipse com o menor erro associado possível (Powell \& Holland, 1994).

Rochas que foram submetidas a condições UHT e que apresentam uma associação mineral preservada geralmente estão associados a áreas onde granulitos "regulares" (Harley, 1989; Harley \& Hensen, 1990; Moraes \& Fuck, 2000; Cooke \& O'Brien, 2001; Moraes et al, 2002) podem ser observados. Essa observação sugere que retrometamorfismo ocorrido com a presença de fusão em fácies granulito pode retornar rochas UHT às associações minerais em equilíbrio no fácies granulito 
(Moraes et al, 2002).

Estudos anteriores mostraram a existência de rochas UHT em determinadas localidades do Complexo Anápolis-Itauçu, sendo Damolândia um deles (Moraes et al., 2002; Baldwin et al., 2005). Associações minerais diagnósticas, como safirina coexistindo com quartzo e ortopiroxênio aluminoso coexistindo com silimanita e quartzo reportadas no CAI e diagnósticas de metamorfismo UHT de rochas supracrustais aluminosas.

Moraes et al. (2002) e Baldwin et al. (2005) utilizaram o software THERMOCALC (Powell \& Holland, 1988; Powell et al., 1998), sendo que o trabalho publicado por Baldwin et al. (2005) aliou seus cálculos ao modelo a-x publicado para safirina (Kelsey et al., 2004) para realização de cálculos no sistema FMAS(H). A amostra utilizada nos estudos de Moraes et al (2002) e Baldwin et al. (2005) éum quartzito impuro, com acamamento composicional definido por proporções variadas de quartzo, ortopiroxênio, granada e silimanita e que exibe foliação pervasiva. O afloramento consiste de blocos isolados de UHT entre granulitos de composição máfica e félsica. Devido à pobre exposição, as relações estruturais entre os granulitos UHT e as rochas associadas não é conhecida.

Moraes et al. (2002) interpretaram a condição mínima de P-T durante o pico metamórfico como tendo sido de $1030-1050{ }^{\circ} \mathrm{C}$ e aproximadamente $10 \mathrm{kbar}$, mas sugerem em seu trabalho que os teores de $\mathrm{Al}_{2} \mathrm{O}_{3}$ nos ortopiroxênios podem indicar temperaturas que excedem $1150{ }^{\circ} \mathrm{C}$. Além disso, Moraes et al. (2002) inferiram trajetória P-T em sentido horário e especularam que a pressão máxima extrapolou os 10 kbar, sendo atingida antes da temperatura máxima registrada.

O modelamento feito por Baldwin et al. (2005) de granulitos UHT ricos em Mg e Al na mesma localidade do CAI indica que a formação inicial de uma associação mineral granada-ortopiroxêniosillimanita-quartzo, de granulação grossa, ocorreu sob condições de $1000{ }^{\circ} \mathrm{C}$ e 9 kbar. O trajeto P-T compatível com as microestruturas observadas envolve um componente de descompressão $(<1$ kbar) seguido por resfriamento $\left(<100^{\circ} \mathrm{C}\right)$.

A diferença das condições P-T calculadas nos dois trabalhos e o motivo por trás disto foge ao escopo do presente estudo e recomenda-se a leitura de Moraes et al. (2002) e Baldwin et al. (2005) para maior detalhamento.

\subsection{Granada-hedembergita granulito}

A rocha modelada consiste em um granada-hedembergita granulito, doravante chamadado apenas de granulito UHT, localizado na região de Damolândia, em contato com o CD. É uma rocha holocristalina, de granulação média a fina e com cristais xenoblásticos. É composta por aproximadamente $45 \%$ de plagioclásio, $35 \%$ de granada e $20 \%$ de clinopiroxênio. Com a exceção de 
um veio de granada visível em lâmina delgada, a rocha apresenta-se homogênea. Observa-se também em lâmina delgada coroa de reação (figura $5^{\circ}, \mathrm{n}$ e p) entre granada (grossulária) e clinopiroxênio (hedembergita) que pode ser descrito pela reação simplificada seguinte

$$
2 \text { Grossulária + Almandina }+3 \text { quartzo = 3Anortita +3Hedembergita }
$$

\subsection{Geotermômetros convencionais}

\subsubsection{Granada-Clinopiroxênio}

Esse geotermômetro é utilizado para rochas de alto grau, como granulitos básicos e intermediários a eclogitos, de ambientes distintos, com clinopiroxênio e granada em sua paragênese. Estudos experimentais da partição de $\mathrm{Fe}^{+2}$ e $\mathrm{Mg}^{2+}$ mostram que a constante $\mathrm{K}_{\mathrm{D}}$ pode ser dada pela expressão

$$
\mathrm{K}_{\mathrm{D}}=\left(\mathrm{Fe}^{+2} / \mathrm{Mg}^{+2}\right)^{\mathrm{Grt}} /\left(\mathrm{Fe}^{+2} / \mathrm{Mg}^{+2}\right)^{\mathrm{Cpx}}
$$

entre granada e clinopiroxênio coexistentes, indicando que esta distribuição é função tanto das condições físicas quanto da variação composicional das fases envolvidas (Råheim \& Green, 1974a; Ellis \& Green, 1979; Pattison \& Newton, 1989; Ai, 1994).

As condições de temperatura foram calculadas por meio dos geotermômetros convencionais de Ellis \& Green (1979), Pattison \& Newton (1989) e Ravna (2000). Foram utilizados 27 pares de GrtCpx nos cálculos geotérmométricos. Pattison \& Newton (1989) fazem uma ressalva quanto aos teores

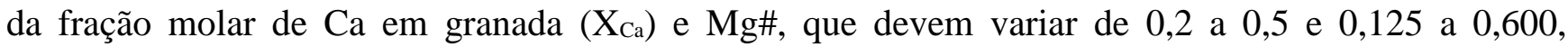
respectivamente. Como os minerais da rocha não se encontram dentro desses limites composicionais, apresentando valores de $\mathrm{X}_{\mathrm{Ca}}$ variando entre 0.74 e 0.85 e de $\mathrm{Mg \#}$ variando entre 0.01 e 0.03 , os dados obtidos a partir desse termômetro não serão apresentados neste trabalho, por não refletirem as verdadeiras condições P e T do granulito UHT. Em contrapartida, os dados obtidos com os termômetros de Ellis \& Green (1979) e Ravna (2000) para os 27 pares de grt-cpx encontram-se detalhados na tabela 3.

Ellis \& Green (1979) mostraram que em pressões entre 24 e 30 kbar e temperaturas variando de 750 a $1300{ }^{\circ} \mathrm{C}$ o $K_{D}$ também depende do conteúdo de Ca na granada e aparentemente independe do conteúdo de $\mathrm{Mg} /(\mathrm{Mg}+\mathrm{Fe})$ tanto do clinopiroxênio quanto da granada. Mesmo tendo sido calibrado para pressões mais altas, os autores afirmam que este termômetro pode ser extrapolado para pressões mais baixas, justamente por apresentar a característica de ser linear. Estes autores afirmam que o efeito do teor de Ca se dá devido às combinações e substituições não ideais em granada e clinopiroxênio.

O termômetro de Ellis \& Green (1979) foi desenvolvido a partir da equação de troca de Fe-Mg entre granada e piroxênio segundo a reação 


$$
\begin{aligned}
& \mathrm{Mg}_{3} \mathrm{Al}_{2} \mathrm{Si}_{3} \mathrm{O}_{12}+3 \mathrm{CaFeSi}_{2} \mathrm{O}_{6}=\mathrm{Fe}_{3} \mathrm{Al}_{2} \mathrm{Si}_{3} \mathrm{O}_{12}+3 \mathrm{CaMgSi}_{2} \mathrm{O}_{6} \\
& \text { (piropo) (hedembergita) (almandina) (diopsídio) }
\end{aligned}
$$

e dá-se pela expressão

$$
\mathrm{T}(\mathrm{K})=\left[3104 \mathrm{X}_{\mathrm{Ca}^{\mathrm{grt}}}+3030+10.86 \mathrm{P}(\mathrm{kbar})\right] /\left[\ln \mathrm{K}_{\mathrm{D}}+1.9034\right]
$$

onde

$\mathrm{Kd}$ : coeficiente de distribuição de Fe e Mg entre granada e clinopiroxênio;

$\mathrm{X}_{\mathrm{Ca}}{ }^{\text {(grt) }}$ : é a fração molar de Ca em granada; e

P: pressão estimada para as rochas em questão.

O geotermômetro de Ravna (2000) é uma revisão dos termômetros de Ellis \& Green (1979) e Pattison \& Newton (1989). Conforme já mencionado, o geotermômetro de Ellis \& Green (1979) mostra relação linear entre o conteúdo de $\mathrm{Ca}$ em granada e ln de $\mathrm{K}_{\mathrm{D}}$ (que foi quantificado e integrado em sua expressão geotermométrica). Pattison \& Newton (1989) compilaram um conjunto de dados extenso, demonstrando que o número de $\mathrm{Mg}\left(\mathrm{Mg \#}=100 \mathrm{X} \mathrm{Mg} /\left(\mathrm{Mg}+\mathrm{Fe}^{+2}\right)\right)$ da granada tem efeito significativo no valor do $K_{D}$. Tendo isso em vista, os autores inseriram uma equação polinomial de terceira ordem a fim de levar este efeito em conta e, a partir disto, derivaram novo geotermômetro (Pattison \& Newton, 1989).

A diferença do geotermômetro de Ravna (2000) é que este leva em consideração o efeito do teor de $\mathrm{Mn}$ em granada no cálculo do $\mathrm{K}_{\mathrm{D}}$. As rochas utilizadas na calibração do termômetro de Ravna (2000) apresentam ampla variação de temperatura $\left(600\right.$ a $\left.1740{ }^{\circ} \mathrm{C}\right)$ e pressão $(10$ a $60 \mathrm{GPa})$, dada pela equação:

$$
\begin{aligned}
\mathrm{T}\left({ }^{\circ} \mathrm{C}\right)= & {\left[\left(1939.9+3270 \mathrm{X}_{\mathrm{Ca}}{ }^{\text {grt }}-1396\left(\mathrm{X}_{\mathrm{Ca}^{\mathrm{grt}}}\right)^{2}+3319 \mathrm{X}_{\mathrm{Mn}^{\mathrm{grt}}}-3535\left(\mathrm{X}_{\mathrm{Mn}^{\mathrm{grt}}}\right)^{2}+1105 \mathrm{X}_{\mathrm{Mg \#}}{ }^{\mathrm{grt}}-\right.\right.} \\
& \left.3561\left(\mathrm{X}_{\mathrm{Mg \#}^{\mathrm{grt}}}\right)^{2}+2324\left(\mathrm{X}_{\mathrm{Mg} \#}\right)^{3}+169.4 \mathrm{P}(\mathrm{GPa})\right] /\left[\left(\ln \mathrm{K}_{\mathrm{D}}+1223-273\right]\right.
\end{aligned}
$$

onde

$$
\begin{aligned}
& X_{\mathrm{ca}}=\mathrm{Ca} /(\mathrm{Ca}+\mathrm{Mn}+\mathrm{Fe}+\mathrm{Mg}) \\
& X_{\mathrm{Mn}}=\mathrm{Mn} /(\mathrm{Ca}+\mathrm{Mn}+\mathrm{Fe}+\mathrm{Mg}) \\
& X_{\mathrm{Mg} \#}=\mathrm{Mg} /(\mathrm{Fe}+\mathrm{Mg})
\end{aligned}
$$

O erro associado a esta equação é de $\pm 100{ }^{\circ} \mathrm{C}$.

O geotermômetro de Ravna (2000) mostra a relação entre as trocas de $\mathrm{Fe}^{+2}-\mathrm{Mg}^{+2}$, o valor de $K_{D}$, variação composicional da granada, pressão e temperatura entre granada e clinopiroxênio coexistentes. As análises experimentais efetuadas no trabalho de Ravna (2000) mostram que variação significativa de $\mathrm{Na}$ (até $\mathrm{X}_{\mathrm{Na}}=0.51$ ) em clinopiroxênio não afeta o resultado das temperaturas calculadas. Por levar em consideração o teor de Mn em granada, o geotermômetro de Ravna (2000) amplia o campo composicional que pode ser modelado na geotermometria. 
Deve-se, entretanto, ter cautela quando geotermômetros convencionais são calculados levando em conta trocas catiônicas simples. Um dos principais motivos disto ser um problema é a troca catiônica tardia durante o resfriamento da rocha, que comumente perturba a composição de pico. Além disso, outro problema adicional na utilização dos termômetros convencionais que levam em consideração a troca de $\mathrm{Fe}^{+2}$ entre as fases coexistentes é que normalmente só se tem dados do valor de ferro total. Portanto, normalmente não se tem a separação entre ferro férrico e ferroso, mesmo havendo várias maneiras de se realizar o cálculo desta razão. Tais cálculos, tanto em granada quanto em piroxênio, são bastante sensíveis a imprecisões analíticas e podem apresentar resultados imprecisos (Ellis \& Green, 1979). No entanto, Ravna (2000) ressalta que anfibolitos máficos “comuns" e granulitos com diopsídio-hedenbergita ricos em Fe não apresentam desvio significativo no valor calculado da temperatura quando o cálculo da razão $\mathrm{Fe}^{+3} / \mathrm{Fe}^{+2}$ é feito com base naestequiometria.

\subsubsection{Aplicação dos geotermômetros convencionais}

No artigo de Ellis \& Green (1979) os autores citaram vários exemplos de sistemas químicos naturais que foram submetidos ao termômetro a fim de verificar sua eficácia. Um dos exemplos foi retirado do artigo de Wood (1975), que descreveu granada-clinopiroxênio ortognaisse na região de South Harris, Escócia. Estimativas de temperaturas baixas reportadas no artigo $\left(\sim 730 \quad{ }^{\circ} \mathrm{C}\right)$ não coincidem com outros métodos citados no mesmo artigo (para maior detalhamento, sugere-se a leitura do artigo de Wood, 1975). Quando os dados publicados no artigo foram submetidos ao termômetro de Ellis \& Green (1979), as temperaturas reportadas entre 790 e $870{ }^{\circ} \mathrm{C}$, provaram ser mais consistentes com os outros métodos reportados no artigo. Outro exemplo citado foi a partir de compilação dos dados do artigo de Green (1969). Nesse artigo, o autor descreve eclogitos que apresentam ampla variação nos teores de $\mathrm{X}_{\mathrm{Ca}} \mathrm{e} \mathrm{Mg \#}$ da granada. Temperaturas reportadas neste artigo variam de 564 a $654{ }^{\circ} \mathrm{C}$ (à pressão de 10 kbar). O termômetro de Ellis \& Green (1979) resultou em temperaturas variando de 635 a $640{ }^{\circ} \mathrm{C}$ que se assemelham às temperaturas reportadas no artigo e também apresentam menor variação.

O termômetro de Ravna (2000) foi testado em sistemas naturais, tanto nos mais simples quanto nos mais complexos, que contém a associação granada-clinopiroxênio. Tais dados foram computados a partir de vários trabalhos publicados. A partir de 404 pares de granada-clinopiroxênio retirados de 27 trabalhos publicados, 311 foram considerados consistentes e foram utilizados, juntamente com dados retirados de 49 sistemas químicos ricos em Mn. Os dados utilizados abrangem amplo intervalo de temperaturas $\left(600-1740{ }^{\circ} \mathrm{C}\right)$, pressões $(10-60 \mathrm{GPa})$ e composições. A tabela 2 foi retirada do trabalho publicado por Ravna (2000) e contém os dados provenientes de sistemas químicos tanto 
naturais quanto sintéticos utilizados na calibração deste geotermômetro.

O geotermômetro de Ellis \& Green (1979) é, assim como o geotermômetro de Ravna (2000), dependente da pressão e, portanto, deve-se assegurar uma boa estimativa desta variável a fim de obter valores mais confiáveis de temperatura. Assim, para o cálculo das temperaturas nos dois geotermômetros, utilizaram-se as pressões de 9 kbar de Baldwin et al. (2005), 10 kbar de Moraes et al. (2002), obtidos no modelamento de granulitos UHT nas proximidades de Damolândia e, de 11 kbar, a fim de testar o efeito da pressão nas temperaturas calculadas com os geotermômetros.

Tabela 2: Dados experimentais de sistemas químicos naturais e sintéticos com grt-cpx coexistentes utilizados na calibração do termômetro de Ravna (2000) (retirado de Ravna (2000)).

\begin{tabular}{|c|c|c|c|c|}
\hline Source & $P(\mathrm{GPa})$ & $T\left({ }^{\circ} \mathrm{C}\right)$ & $\begin{array}{l}\text { No of } \\
\text { pairs } \\
\text { given }\end{array}$ & $\begin{array}{l}\text { No. of } \\
\text { pairs } \\
\text { used }\end{array}$ \\
\hline Rảheim \& Green (1974a) & $2,0-4.0$ & $600-1500$ & 39 & 33 \\
\hline Râheim \& Green (1974b) & $1.2-3.0$ & $1100-1300$ & 6 & 3 \\
\hline Irving (1974) & $1.53-2.7$ & $1100-1200$ & 4 & 4 \\
\hline Akella (1976) & $3,1-4.4$ & $1100-1300$ & 3 & 1 \\
\hline Eliss \& Green (1979) & $1.5-3.0$ & $750-1300$ & 45 & 32 \\
\hline Johnston (1986) & $2.3-3.0$ & $1275-1455$ & 7 & 6 \\
\hline Carrol \& Wyllie (1989) & 1.5 & $850-1030$ & 10 & 6 \\
\hline Mengel \& Green (1989) & $2.5-2.8$ & $975-1250$ & 11 & 7 \\
\hline Brey ef al. (1990) & $2.8-6.0$ & $900-1400$ & 56 & 48 \\
\hline Wallace \& Green (1991) & $20-3.0$ & $900-1100$ & 15 & 11 \\
\hline Green \& Adam (1991) & $1.0-3.0$ & $950-1200$ & 17 & 17 \\
\hline Green (1992) & 1.5 & 950 & 1 & 1 \\
\hline Draper \& Johnston ( 1992 ) & $1.5-2.0$ & $1250-1400$ & 7 & 4 \\
\hline Poli (1993) & $20-2.6$ & 650 & 3 & 3 \\
\hline Rushmer (1993) & 1.8 & 950 & 1 & 1 \\
\hline Bertka \& Holloway (1994) & 24 & 1320 & 1 & 1 \\
\hline $\mathrm{Ai}(1994)$ & $2.5-3.8$ & $1200-1500$ & 47 & 45 \\
\hline Sen \& Dunn (1994) & $1.5-2,0$ & $925-1150$ & 13 & 10 \\
\hline Mitchell (1995) & $5.0-7.0$ & $1200-1600$ & 12 & 4 \\
\hline Patiño Douce \& Beard (1995) & $1.25-1.5$ & $930-1000$ & 8 & 6 \\
\hline Rapp \& Watson (1995) & $1.6-3.2$ & $980-1150$ & 38 & 24 \\
\hline Longhi (1995) & 3.0 & $1490-1538$ & 4 & 4 \\
\hline Skjerlie \& Johnston (1996) & $1,0-2.9$ & $850-1000$ & 18 & 15 \\
\hline Draper \& Groen (1997) & 3.0 & 1300 & 1 & 1 \\
\hline Springer \& Seck (1997) & $1.25-1.5$ & $900-1100$ & 5 & 2 \\
\hline Walter (1998) & $3.0-7.0$ & $1500-1820$ & 17 & 9 \\
\hline Ernst \& Liu ( 1998 ) & $1.2-2.2$ & $650-950$ & 15 & 13 \\
\hline Total experimental data & & & 404 & 311 \\
\hline \multicolumn{5}{|l|}{ Natural Mn-rich assemblages } \\
\hline Dahl (1980) & 0.7 & 680 & 10 & 10 \\
\hline Devaraju \& Laajoki (1986) & 0.7 & 735 & 13 & 12 \\
\hline Mahabaleswar (1986) & 0.7 & 735 & 17 & 14 \\
\hline Bhattacharya et al. (1990) & 0.7 & 735 & 13 & 13 \\
\hline
\end{tabular}

O granulito UHT regional utilizado no modelamento geotermobarométrico apresenta grossulária, andradita e hedembergita em sua paragênese de pico metamórfico. Assim, estando esses minerais em equilíbrio durante o pico do metamorfismo, os geotermômetros e geobarômetros convencionais podem ser empregados no cálculo geotermobarométrico do granada-hedembergita granulito. 
Tabela 3: Valores das temperaturas obtidos para os geotermômetros convencionais de Ellis \& Green (1979) e Ravna (2000) em pressões de 9, 10 e 11 kbar (Baldwin et al., 2005; Moraes et al., 2002).

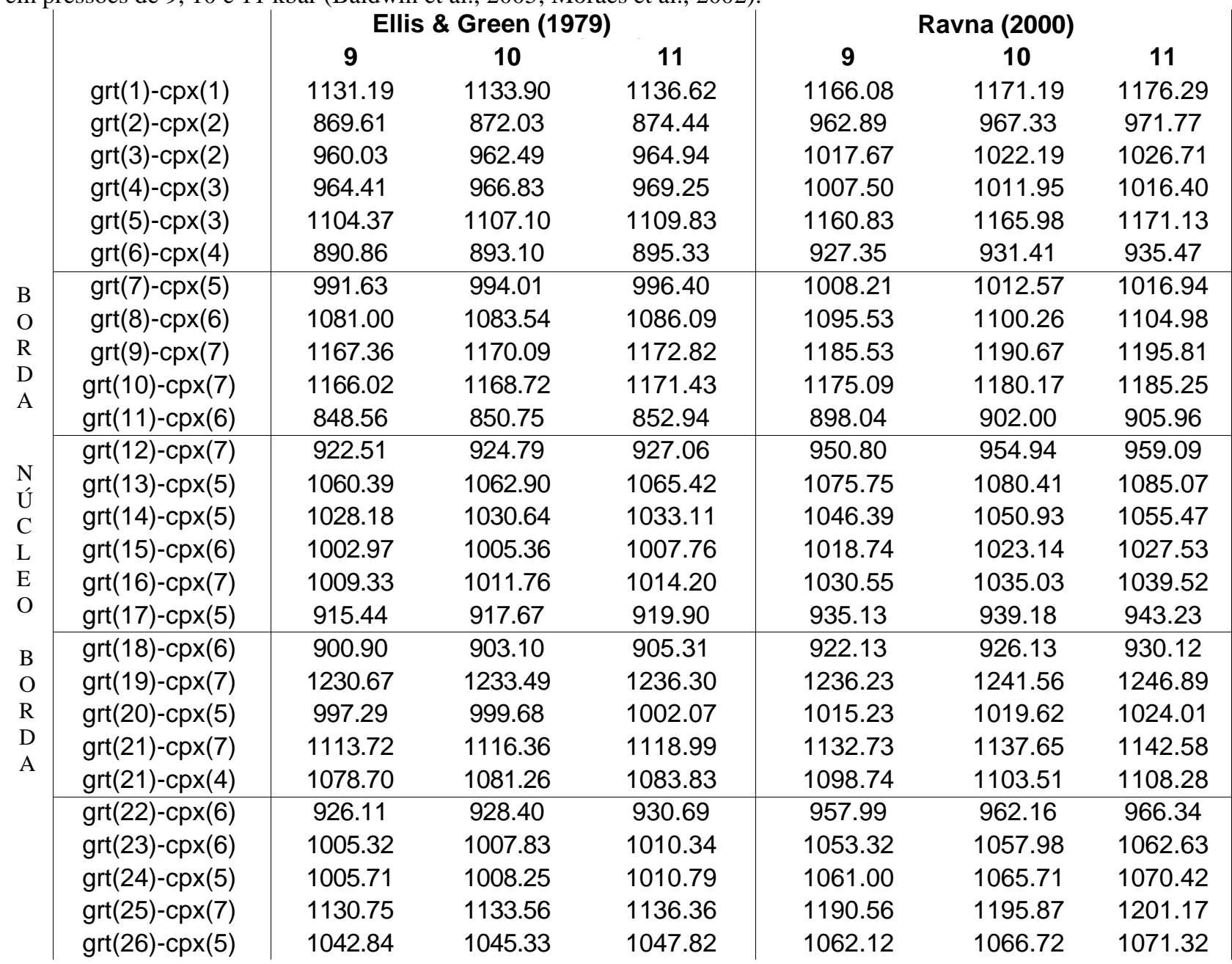

Conforme se verifica na tabela 3, os valores obtidos para o termômetro de Ravna (2000) são superiores aos observados para o termômetro de Ellis \& Green (1979) o que se deve ao fato do primeiro levar em consideração a variação de $X_{M n}$ na granada (figura 26). Não se observa correlação positiva entre os valores dos teores de $\mathrm{X}_{\mathrm{Ca}}$ da granada e as temperaturas observadas, tanto para $\mathrm{O}$ termômetro de Ellis \& Green (1979) quanto para o de Ravna (2000), o que pode ser verificado na figura 26a e b, onde se observa que para teores semelhantes de $\mathrm{X}_{\mathrm{Ca}}$ há uma variação significativa nos valores da temperatura. Essa falta de correlação positiva pode ser devido aos altos teores de Ca observados nessa rocha. Tão pouco se observa correlação entre os teores de $\mathrm{X}_{\mathrm{Mn}}$ da granada e os valores das temperaturas calculadas, conforme pode ser verificado pela figura 26c. Talvez isso se deva ao fato do granulito UHT não apresentar teores significativos de $\mathrm{MnO}$, variando de 0.02 até 0.439 wt \% (tabela clinopiroxênio, anexo I). Mesmo levando-se isso em consideração, as temperaturas obtidas com os 
termômetros em questão revelam temperaturas UHT.
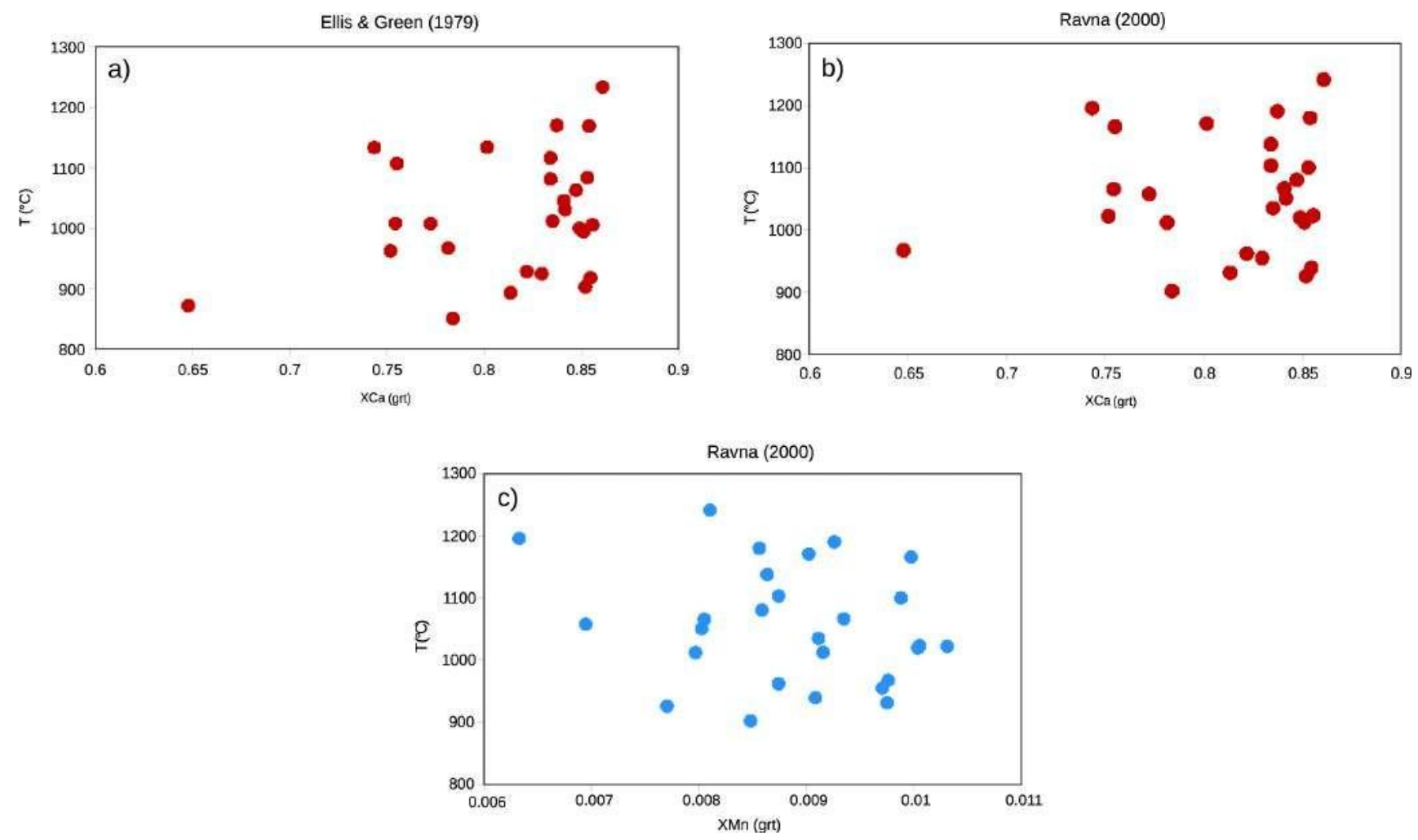

Figura 26: a) Teores da fração molar de $\mathrm{Ca}\left(\mathrm{X}_{\mathrm{ca}}\right)$ da granada versus as temperaturas $\left({ }^{\circ} \mathrm{C}\right)$ obtidas com o geotermômetro de Ellis \& Green (1979); e b) Ravna (2000); c) teores da fração molar de Mn ( $\left.\mathrm{X}_{\mathrm{mn}}\right)$ da granada versus as temperaturas obtidas com o termômetro de Ravna (2000).

Os pares analisados entre grt7 e grt21 representam as análises em cima do perfil composicional apresentado no sub item silicatos. A variação das temperaturas de Ellis \& Green (1979) e Ravna (2000) ao longo do perfil composicional é apresentada na figura 27. Observa-se que as temperaturas registradas no centro são inferiores às observadas nas bordas, o que pode ser justificado por metamorfismo heterogêneo ou por dados calculados em desequilíbrio. Ou seja, os dados de temperatura obtidos para valores acima de $\sim 1000-1100{ }^{\circ} \mathrm{C}$ podem ter sido obtidos a partir de análises conjuntas de núcleo e borda da granada e do clinopiroxênio e que, portanto, não estariam em equilíbrio. 
a)

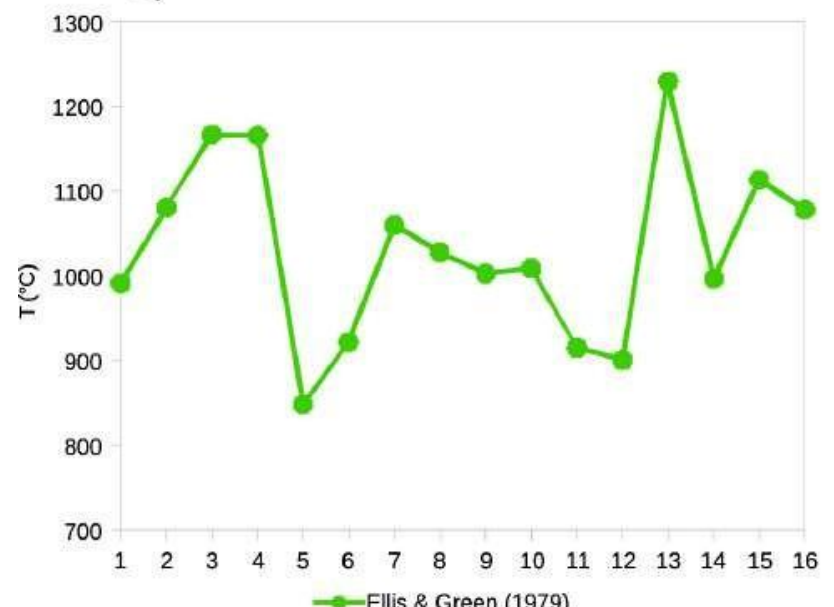

b)

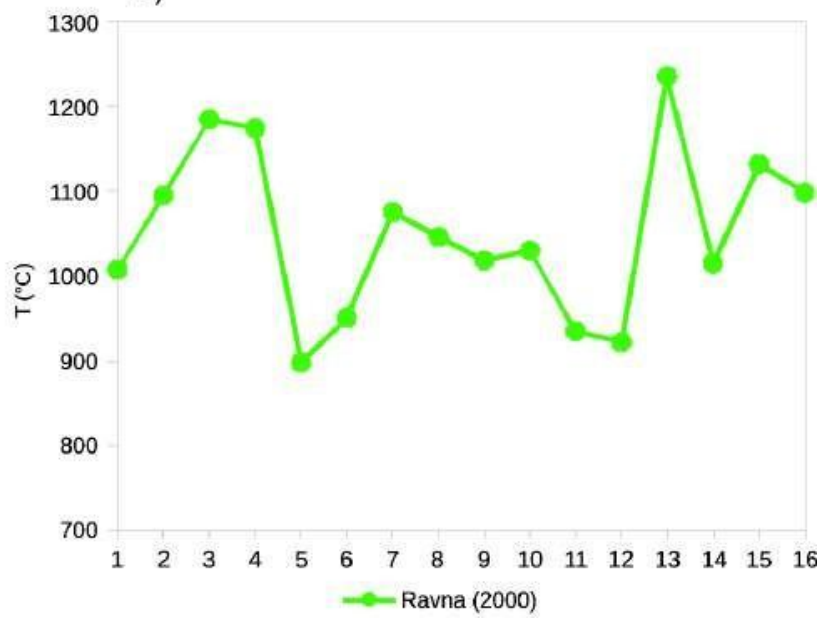

Figura 27: a) Variação das temperaturas calculadas com os termômetros de Ellis \& Green (1979); e b) Ravna (2000), ao longo do perfil composicional da granada.

A fim de manter a consistência interna dos dados reportados, as pressões estimadas para o cálculo das temperaturas foram refinadas com o uso do geobarômetro adequado, que será detalhado abaixo. As temperaturas utilizadas para o cálculo sistemático das pressões foram as obtidas tanto com $\mathrm{o}$ termômetro de Ellis \& Green quanto com o de Ravna, obtidos para a menor pressão investigada, reportada por Baldwin et al. (2005).

\subsection{Geobarômetros convencionais}

\subsubsection{Granada-piroxênio-plagioclásio-quartzo}

Vários geobarômetros aplicados às rochas em fácies granulito se baseiam em reações entre os membros finais de minerais que coexistem. Dois dos principais geobarômetros utilizados contemplam as associações mineralógicas de plagioclásio + piroxênio + granada + quartzo, sendo aplicáveis para metabasaltos e metapelitos. Moecher et al. (1988) descrevem o geobarômetro da reação

$$
3 \mathrm{Hed}+3 \mathrm{An}=2 \mathrm{Grs}+\mathrm{Alm}+3 \mathrm{Qtz}
$$

que chamou de geobarômetro 'HD' e foi recalculado para o sistema $\mathrm{CaO}-\mathrm{Al}_{2} \mathrm{O}_{3}-\mathrm{FeO}-\mathrm{MgO}-\mathrm{SiO}_{2}$, baseado em dados termodinâmicos obtidos de diferentes fontes e derivado de uma variedade de equilíbrios experimentais. Com base nesses dados, a constante K calculada por Moecher et al. (1988) para o barômetro HD é

$$
\mathrm{K}=\left[\left(\mathrm{a}^{2} \mathrm{Gr} \cdot \mathrm{aAlm}\right) /\left(\mathrm{a}^{3} \mathrm{An} \cdot \mathrm{a}^{3} \mathrm{Hd}\right)\right]
$$

onde "a" é a atividade no sistema "a-x" calculada para os membros finais das fases minerais da reação. Deve-se considerar que a aplicação desse equilíbrio para os sistemas naturais requer a consideração da redução da atividade dos membros finais dos componentes devido à ocorrência de soluções sólidas em 
plagioclásio, granada e clinopiroxênio.

Posteriormente, Essene (1989) sumarizou os principais geobarômetros convencionais e apresentou a constante $\mathrm{K}$ calculada para a reação inversa que, por melhor se encaixar com o que é observado pela rocha UHT aqui descrita, é a que será usada para o cálculo da pressão no presente capítulo e é dada por:

$$
\mathrm{K}=\left[\left(\mathrm{a}^{3} \mathrm{An} \cdot \mathrm{a}^{3} \mathrm{Hd}\right) /\left(\mathrm{a}^{2} \mathrm{Gr} \cdot \mathrm{aAlm}\right)\right]
$$

A partir do cálculo apropriado dos modelos de atividade para plagioclásio, granada e clinopiroxênio, a constante $\mathrm{K}$ pode ser calculada. Com estes valores em mãos e aliando-os a uma estimativa de temperatura confiável, a pressão pode ser calculada com o auxílio das curvas de $\operatorname{logK}$ (figura 28) sem que se faça necessária a utilização de outro aparato matemático. Os valores de pressão obtidos com essas ferramentas foram compilados na tabela 4.

Conforme já mencionado, as temperaturas utilizadas nas estimativas das pressões foram as calculadas tanto com o geotermômetro de Ellis \& Green (1979) como com o de Ravna (2000). Como a variação dos valores de $\mathrm{T}$ observados no mesmo termômetro para as três pressões inicialmente utilizadas é pequeno (em geral de 2 ou $3{ }^{\circ} \mathrm{C}$ ), as temperaturas escolhidas para o refinamento das pressões foram as obtidas para a pressão de 9 kbar proposta por Baldwin et al., (2005).

Segundo Moecher et al. (1988), na aplicação do barômetro HD deve se ter cuidado com a extrapolação da pressão em sistemas ricos em Mg. Durante os testes com o barômetro observou-se que as maiores discrepâncias foram registradas em piroxênios com altos valores de Mg\#, o que se deve ao fato de que, de maneira geral, piroxênios nas associações grt-cpx-opx-plg-qtz se tornam mais magnesianos e aluminosos conforme a pressão aumenta (Moecher et al., 1988). Os autores também destacam também que, quanto maior a pressão, maior a extrapolação do membro final do sistema Fe e, portanto, menos confiáveis serão as pressões calculadas pelo geobarômetro HD. Os valores de Mg\# para clinopiroxênio do granulito UHT variam de 0,15 a 0,23 . 


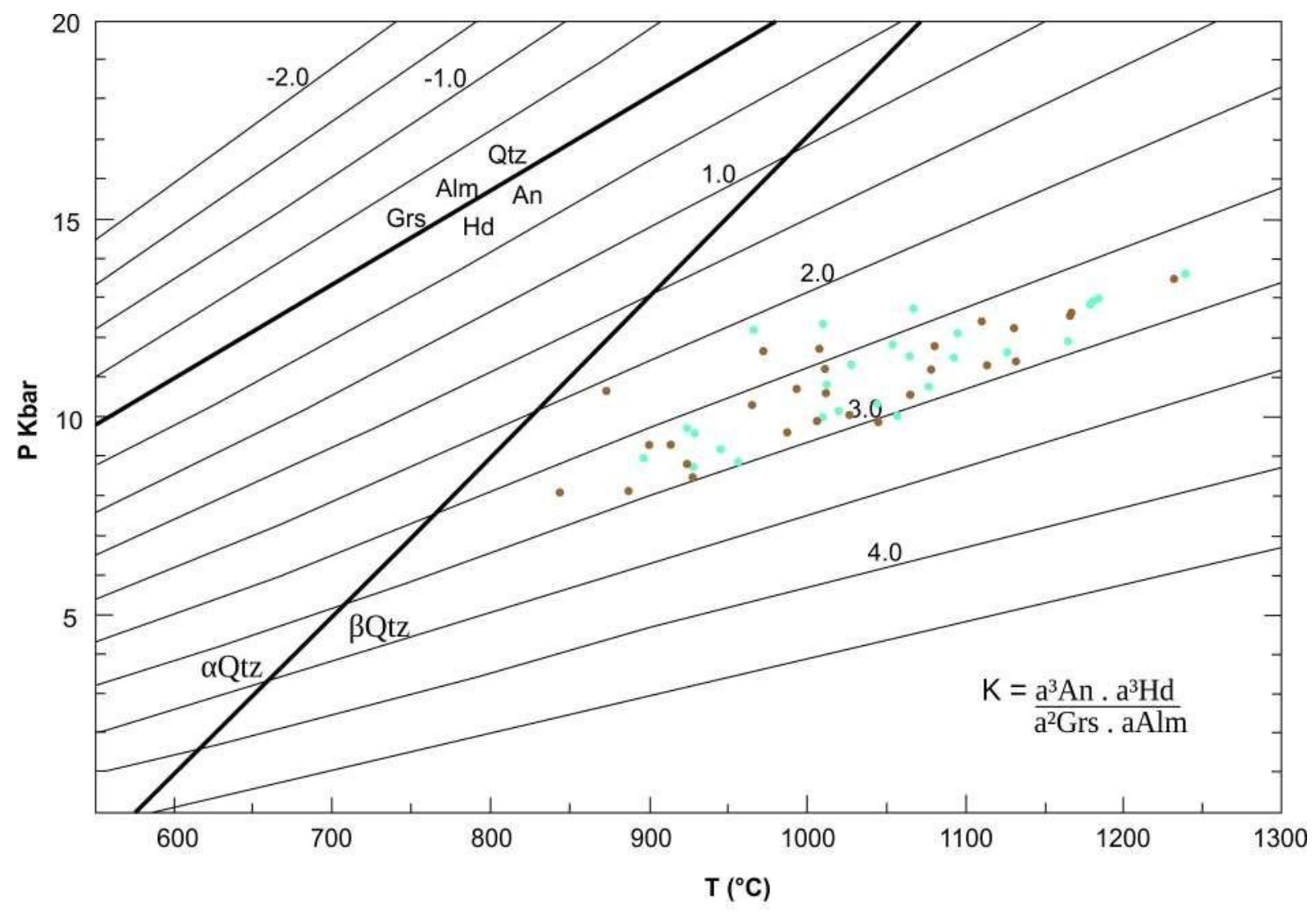

Ėliis \& Grēen (197́9) ${ }^{-\cdots}$

Ravna (2000)

Figura 28: Gráfico do cálculo das pressões por meio das curvas de logK (modificado de Essene, 1989).

As pressões calculadas com o geobarômetro HD foram realizadas com as mesmas associações minerais utilizadas para os cálculos de temperatura. Análise das tabelas 3 e 4 revela que as maiores pressões são verificadas nas amostras que apresentam as maiores temperaturas calculadas, o que evidencia estrita relação entre a pressão e a temperatura para este sistema, o que pode ser verificado na figura 30. A dependência da temperatura por parte do barômetro HD pode ser considerada confiável dentro de uma incerteza de $\pm 50{ }^{\circ} \mathrm{C}$ no cálculo de $\operatorname{logK}$. Para este grau de incerteza o valor do erro associado de $\mathrm{K}$ é de 1 a $2 \%$ e, portanto, a pressão varia em \pm 1 kbar (Moecher et al., 1988).

Além desta dependência intrínseca da temperatura, que pode ser verificada nos gráficos da figura 30, variações composicionais na ordem de $1 \mathrm{~mol} \%$ de An no plagioclásio, Hed no clinopiroxênio e Alm na granada correspondem a variações de pressão na ordem de 0.1 kbar. Já uma variação composicional de Grs apresenta efeitos até duas vezes maiores (Moecher et al, 1988). Assim como se observa para as temperaturas, variação das pressões ao longo do perfil composicional da granada também pode ser observada (figura 29). 
a)

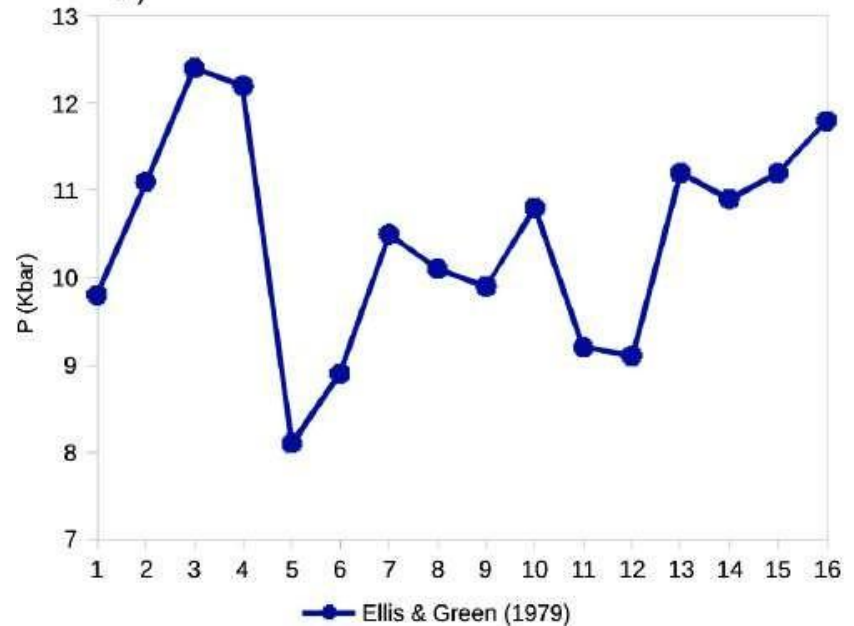

b)

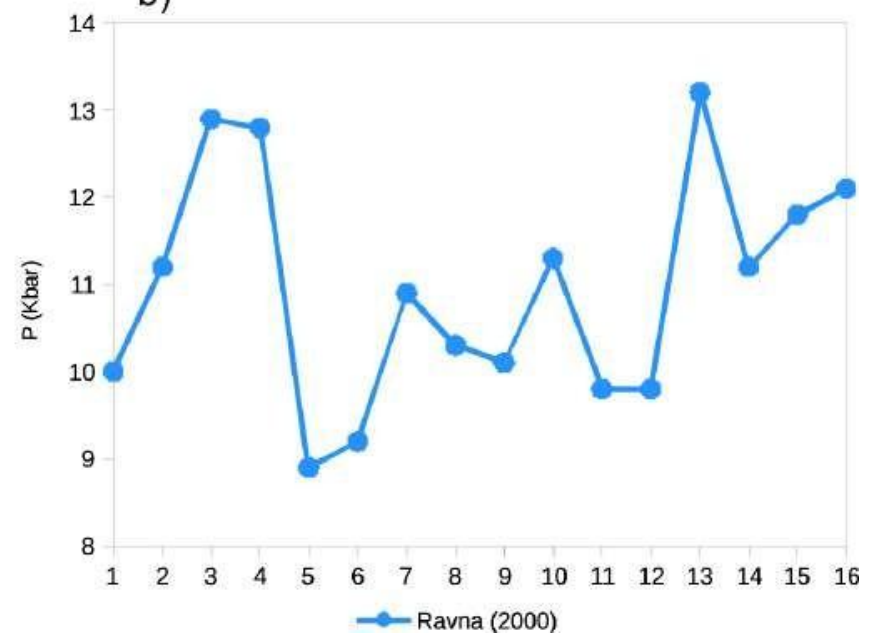

Figura 29: a) Variação das pressões calculadas com o barômetro de Moecher et al. (1988) para as temperaturas de Ellis \& Green (1979); e b) Ravna (2000).

As pressões calculadas acima de 10 kbar obtidas com o geobarômetro de Moecher et al. (1988) podem ter sido obtidas com dados em desequilíbrio, ou seja, calculadas entre núcleo e borda entre a granada e o clinopiroxênio. Para que cálculos geotermobarométricos sejam confiáveis os pares de granada e clinopiroxênio devem estar em equilíbrio e valores de pressão e temperatura obtidos com dados conjuntos de núcleo e borda estão em desequilíbrio. Por ser dependente da temperatura, os valores de pressão calculados apresentam comportamento bastante semelhante ao das temperaturas apresentadas na figura 27. Esse comportamento pode também ser interpretado como resultado de metamorfismo heterogêneo ou, conforme mencionado, devido a alguns cálculos em desequilíbrio.

Segundo Moecher et al. (1988), altos teores de $\mathrm{X}_{\mathrm{Ca}}$ da granada também podem gerar extrapolação nos valores das pressões. No entanto, conforme pode ser observado na figura 26, não se observa correlação positiva da pressão com os teores de $\mathrm{X}_{\mathrm{Ca}}$ das granada, de maneira semelhante às temperaturas calculadas. Na rocha UHT descrita, os teores de $\mathrm{X}_{\mathrm{Ca}}$ ficam em torno de 0.80, o que é considerado alto para as rochas descritas no artigo de Moecher et al. (1988). Foram observadas pressões elevadas ( 13 kbar) no oeste da Província Greenville pelos autores, justificados pelos alto valor da fração molar da granada $(\sim 0.95)$.

Uma alternativa seria aplicar o geobarômetro de Newton \& Perkins (1982) que utiliza a atividade do diopsídio ao invés da hedembergita, porém segundo Moecher et al. (1988) esse geobarômetro tem o efeito inverso do barômetro HD nas pressões, ou seja, em rochas com altos valores de $\mathrm{X}_{\mathrm{Ca}}$ na granada, o barômetro subestima as pressões, apresentando valores muito inferiores aos verdadeiros. Dessa forma, o barômetro HD ainda continua sendo mais confiável para a reação (3) (grs 
+ alm + qtz $=$ an + hed).

Tabela 4: Valores de pressões calculadas com o geobarômetro de Essene (1989) com as temperaturas calculadas com o geotermômetro de Ellis \& Green (1979) e Ravna (2000), respectivamente.

\begin{tabular}{c|c|c|c|c|c|} 
& & K & logK & Ellis \& Green (1979) & Ravna (2000) \\
& grt1-cpx1-plg1 & 808.89 & 2.91 & 11.3 & 11.9 \\
& grt2-cpx2-plg2 & 148.49 & 2.17 & 10.80 & 12.10 \\
& grt3-cpx2-plg3 & 332.17 & 2.52 & 10.20 & 10.90 \\
& grt4-cpx3-plg4 & 505.97 & 2.70 & 11.80 & 12.20 \\
& grt5-cpx3-plg5 & 386.28 & 2.59 & 12.30 & 13.00 \\
& grt6-cpx4-plg6 & 890.35 & 2.95 & 8.10 & 8.90 \\
\hline B & grt7-cpx5-plg7 & 781.35 & 2.89 & 9.80 & 10.00 \\
O & grt8-cpx6-plg1 & 601.87 & 2.78 & 11.10 & 11.20 \\
R & grt9-cpx7-plg2 & 614.60 & 2.79 & 12.40 & 12.90 \\
D & grt10-cpx7-plg3 & 590.72 & 2.77 & 12.20 & 12.80 \\
A & grt11-cpx6-plg4 & 552.59 & 2.74 & 8.10 & 8.90 \\
\hline N & grt12-cpx7-plg6 & 677.87 & 2.83 & 8.90 & 9.20 \\
Ú & grt13-cpx5-plg7 & 840.71 & 2.92 & 10.50 & 10.90 \\
C grt14-cpx5-plg1 & 804.57 & 2.91 & 10.10 & 10.30 \\
L & grt15-cpx6-plg2 & 805.45 & 2.91 & 9.90 & 11.10 \\
E & grt16-cpx7-plg3 & 561.52 & 2.75 & 10.80 & 9.80 \\
O grt17-cpx5-plg4 & 570.41 & 2.76 & 9.20 & 9.80 \\
& grt18-cpx6-plg5 & 526.37 & 2.72 & 9.10 & 13.20 \\
B & grt19-cpx7-plg6 & 611.48 & 2.79 & 11.20 & 11.20 \\
O & grt20-cpx5-plg7 & 458.60 & 2.66 & 10.90 & 11.80 \\
D & grt21-cpx7-plg8 & 734.14 & 2.87 & 11.20 & 12.10 \\
\hline A grt21-cpx6-plg9 & 547.33 & 2.74 & 11.80 & 8.90 \\
& grt22-cpx6-plg12 & 986.69 & 2.99 & 8.50 & 11.80 \\
& grt23-cpx6-plg13 & 373.84 & 2.57 & 11.10 & 12.70 \\
& grt24-cpx5-plg14 & 276.90 & 2.44 & 11.80 & 10.00 \\
& grt25-cpx7-plg15 & 450.83 & 2.65 & 12.10 &
\end{tabular}
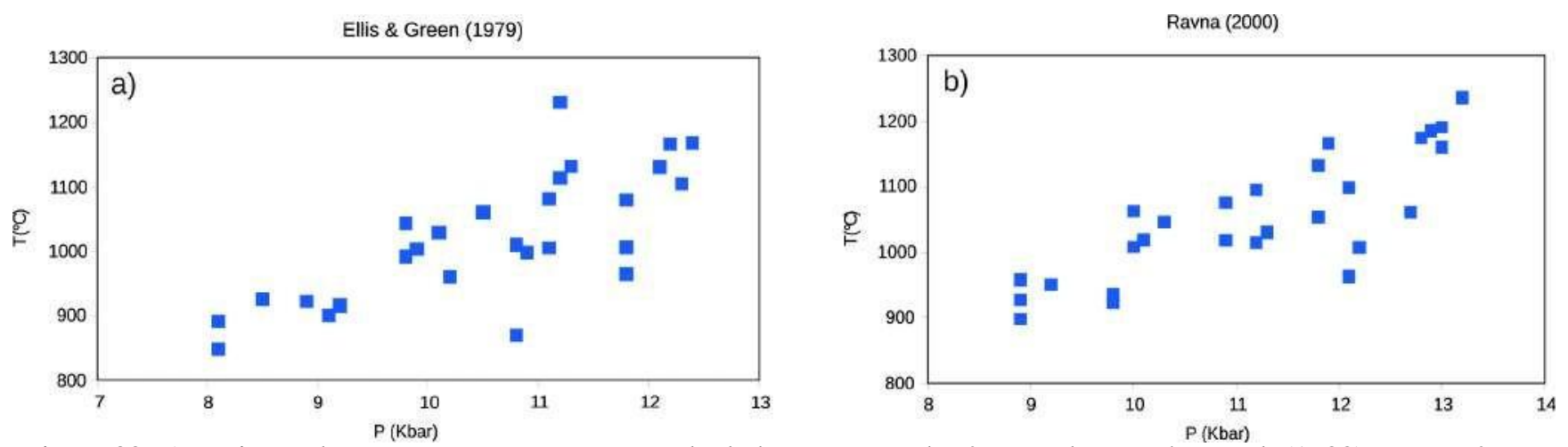

Figura 30: a) Variação das temperaturas e pressões calculadas com o geobarômetro de Moecher et al. (1988) e o termômetro de Ellis \& Green (1979); e b) Ravna (2000). 

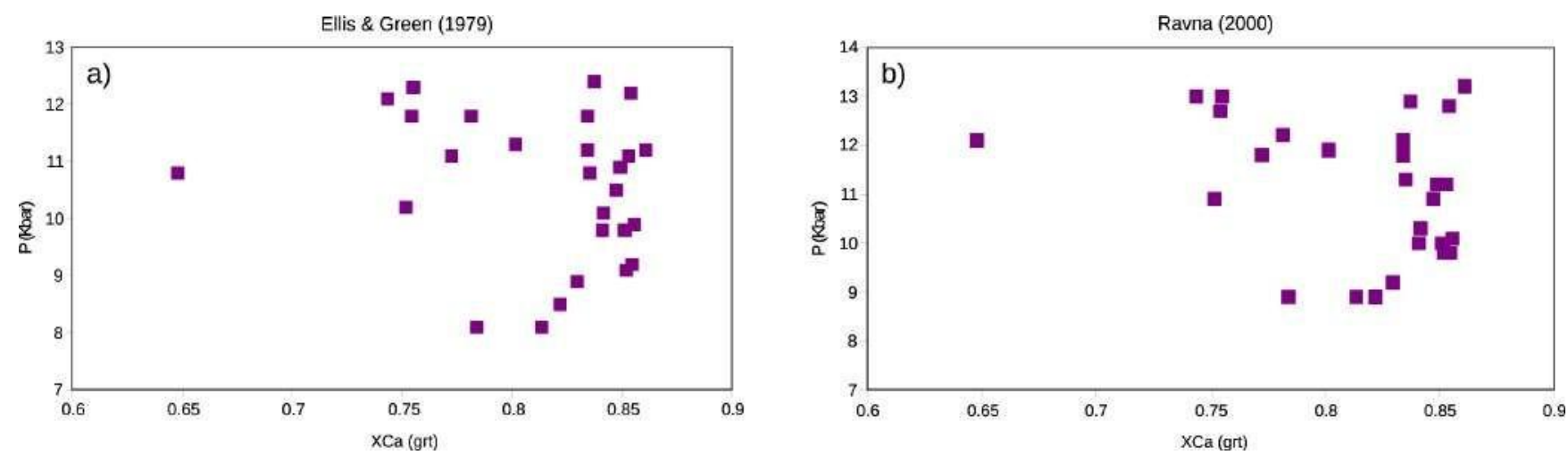

Figura 31: Valores de $\mathrm{X}_{\mathrm{Ca}}$ das granada versus as pressões calculadas com o geobarômetro HD de Moecher et al. (1988) para as pressões de a) Ellis \& Green (1979); e b) Ravna (2000).

\subsection{Geotermobarometria otimizada (THERMOCALC)}

Conforme já mencionado, as condições de pressão (P) e temperatura (T) também foram calculadas por métodos otimizados, por meio do uso de softwares como o THERMOCALC v3.33. No softtware THERMOCALC os cálculos de $\mathrm{P}$ e $\mathrm{T}$ foram realizados por meio do método avPT (average $P T)$ e estes valores foram então utilizados no refinamento dos dados calculados com os métodos avP (average P) e avT (average T), seguindo as recomendações de Holland \& Powell (2011). Os resultados obtidos são indicados na tabela 5.

As mesmas associações minerais utilizadas nos geotermômetros de Ellis \& Green (1979) e Ravna (2000) e para o cálculo das pressões com o geobarômetro HD de Moecher et al. (1988) foram empregadas para os cálculos das condições $\mathrm{P}$ e $\mathrm{T}$ usando o THERMOCALC. Foram obtidos 26 resultados utilizando-se estas associações. Duas das associações investigadas não foram computadas pelo THERMOCALC pois a atividade "a- $\mathrm{x}$ " não pode ser calculada para algumas fases com o software AXWin (Holland \& Powell, 2011).

Os valores calculados de pressão apresentam variação de 8.6 até 10.7 kbar no método avP e 8.2 a 10.7 kbar no método avPT. Em geral, a variação entre esses dois métodos não é muito significativa, sendo superior a $1 \mathrm{kbar}$ em apenas um caso (grt23-cpx6-plg13). As temperaturas apresentam variação mais significativa, de 828 a $1018{ }^{\circ} \mathrm{C}$ no método avT e 814 a $1018{ }^{\circ} \mathrm{C}$ no método avPT. A variação entre as temperaturas calculadas por estes dois métodos apresenta o maior valor no mesmo ponto que a pressão, sendo da ordem de $66^{\circ} \mathrm{C}$. Cabe ressaltar que as pressões calculadas com o geobarômetro convencional de Moecher et al (1988) e as calculadas com o software THERMOCALC apresentam disparidade significativa entre si. 
Tabela 5: Cálculo das pressões e temperaturas da rocha UHT com os métodos avP, avT e avPT com o software THERMOCALC v3.33.

\begin{tabular}{|c|c|c|c|c|}
\hline & & avP \& avT ( & calc v 3.33) & \\
\hline & & avP (Kbar) & avT $\left({ }^{\circ} \mathrm{C}\right)$ & avPT \\
\hline & grt1-cpx1-plg1 & $9.7 \pm 1.14$ & $951 \pm 102$ & $9.5 \pm 1.14 / 936 \pm 107$ \\
\hline & grt2-cpx2-plg2 & - & - & - \\
\hline & grt3-cpx2-plg3 & - & - & - \\
\hline & grt4-cpx3-plg4 & $9.7 \pm 1.2$ & $939 \pm 83$ & $9.5 \pm 2.81 / 926 \pm 88$ \\
\hline & grt5-cp 3 -plg5 & $9.7 \pm 1.55$ & $905 \pm 75$ & $9.6 \pm 1.6 / 898 \pm 78$ \\
\hline & grt6-cpx4-plg6 & $9.7 \pm 1.3$ & $997 \pm 108$ & $9.3 \pm 1.19 / 978 \pm 118$ \\
\hline $\mathrm{B}$ & grt7-cpx5-plg7 & $9.6 \pm 1.1$ & $961 \pm 78$ & $9.5 \pm 1.15 / 955 \pm 78$ \\
\hline $\begin{array}{l}\mathrm{B} \\
\mathrm{O}\end{array}$ & grt8-cpx6-plg1 & $9.5 \pm 2.05$ & $923 \pm 51$ & $9.9 \pm 1.12 / 961 \pm 51$ \\
\hline $\mathrm{R}$ & grt9-cpx7-plg2 & $9.5 \pm 1.11$ & $918 \pm 71$ & $9.9 \pm 1.09 / 948 \pm 71$ \\
\hline $\mathrm{D}$ & grt10-cpx7-plg3 & $9.6 \pm 1.1$ & $926 \pm 72$ & $9.9 \pm 1.09 / 952 \pm 71$ \\
\hline A & grt11-cpx6-plg4 & $9.0 \pm 2.05$ & $880 \pm 51$ & $8.5 \pm 2.08 / 831 \pm 51$ \\
\hline & grt12-cpx7-plg6 & $9.4 \pm 1.12$ & $926 \pm 73$ & $9.7 \pm 1.11 / 946 \pm 73$ \\
\hline $\begin{array}{l}N \\
\text { Ú }\end{array}$ & grt13-cpx5-plg7 & $9.6 \pm 1.14$ & $962 \pm 79$ & $9.4 \pm 1.16 / 954 \pm 79$ \\
\hline $\mathrm{C}$ & grt14-cpx5-plg1 & $9.6 \pm 1.13$ & $963 \pm 78$ & $9.5 \pm 1.15 / 956 \pm 78$ \\
\hline $\mathrm{L}$ & grt15-cpx6-plg2 & $9.6 \pm 1.18$ & $960 \pm 83$ & $9.5 \pm 1.16 / 953 \pm 83$ \\
\hline $\mathrm{E}$ & grt16-cpx7-plg3 & $10.6 \pm 1.2$ & $1008 \pm 89$ & $10.7 \pm 1.13 / 1016 \pm 86$ \\
\hline $\mathrm{O}$ & grt17-cpx5-plg4 & $10.7 \pm 1.14$ & $1018 \pm 75$ & $10.7 \pm 1.14 / 1018 \pm 75$ \\
\hline B & grt18-cpx6-plg5 & $8.6 \pm 2.0$ & $845 \pm 77$ & $8.3 \pm 2.08 / 831 \pm 74$ \\
\hline $\begin{array}{l}\mathrm{B} \\
\mathrm{O}\end{array}$ & grt19-cpx7-plg6 & $9.5 \pm 1.05$ & $921 \pm 96$ & $9.9 \pm 1.09 / 950 \pm 71$ \\
\hline $\mathrm{R}$ & grt20-cpx5-plg7 & $9.7 \pm 1.1$ & $930 \pm 77$ & $9.5 \pm 1.29 / 917 \pm 81$ \\
\hline D & grt21-cpx7-plg8 & $9.5 \pm 1.12$ & $949 \pm 72$ & $9.6 \pm 1.10 / 955 \pm 72$ \\
\hline A & grt21-cpx4-plg10 & $9.6 \pm 1.3$ & $927 \pm 74$ & $9.8 \pm 1.1 / 947 \pm 74$ \\
\hline & grt22-cpx6-plg12 & $9.4 \pm 1.6$ & $956 \pm 86$ & $9.2 \pm 1.2 / 942 \pm 85$ \\
\hline & grt23-cpx6-plg13 & $9.8 \pm 1.03$ & $890 \pm 48$ & $8.2 \pm 2.08 / 814 \pm 50$ \\
\hline & grt24-cpx5-plg14 & $9.1 \pm 1.14$ & $828 \pm 79$ & $8.9 \pm 1.85 / 816 \pm 81$ \\
\hline & grt25-cpx7-plg15 & $9.6 \pm 1.02$ & $902 \pm 69$ & $9.4 \pm 1.11 / 887 \pm 109$ \\
\hline & grt26-cpx5-plg13 & $9.4 \pm 1.12$ & $970 \pm 89$ & $9.0 \pm 1.18 / 942 \pm 100$ \\
\hline
\end{tabular}

Levando-se em consideração que a correlação entre os valores de avPT dos dados obtidos com o THERMOCALC é na ordem de 0.92 a 0.97 e que o geobarômetro HD tende a extrapolar as pressões para rochas que apresentam altos teores de $\mathrm{X}_{\mathrm{Ca}}$ em granada, assume-se que as pressões calculadas com o software são mais confiáveis e serão, portanto, assumidas como sendo as pressões referentes à rocha UHT. Já as temperaturas calculadas pelo software se assemelham mais ao geotermômetro de Ellis \& Green (1979) do que às do termômetro de Ravna (2000) e serão assumidas, de maneira conjunta com as pressões, como sendo as temperaturas referentes para essa rocha. Assim como para os geotermobarômetros convencionais aplicados no modelamento desta rocha, os valores de temperatura (T) e pressão (P) obtidos com o software THERMOCALC também apresentam dependência significativa, o que pode ser observado na figura 32. 

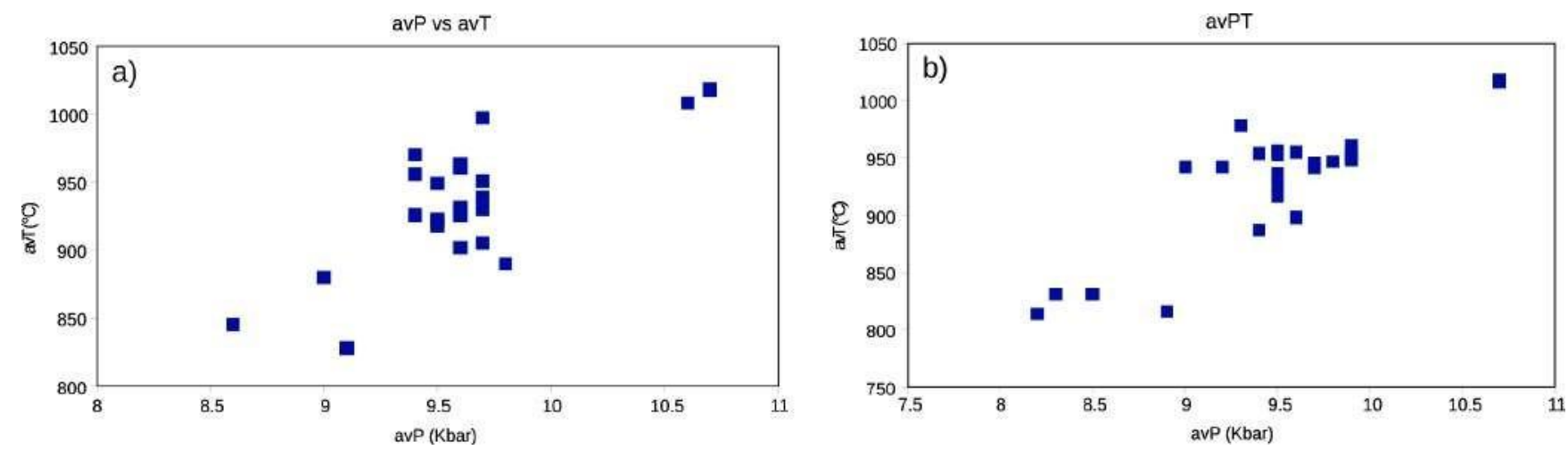

Figura 32: a) Valores de pressão (P) versus temperatura (T) para ao dados obtidos com o software THERMOCALC no modo avPT quanto b) avP e avT.

Ao longo do perfil composicional da granada observa-se a variação dos valores de avP e avT na figura 33. O comportamento reflete mais o que seria esperado nessas condições metamórficas, onde o núcleo registra as condições mais altas de $\mathrm{P}$ e $\mathrm{T}$ e as bordas apresentam valores inferiores, provavelmente como reflexo de trocas cationicas tardias de $\mathrm{Mg}-\mathrm{Fe}^{+2}$ durante o resfriamento da rocha. Mesmo levando-se isso em conta, os golfos observados nas bordas sugerem a ocorrência de metamorfismo heterogêneo, dado que valores de $\mathrm{P}$ e $\mathrm{T}$ registrados no pico metamórfico não transicionam suavemente para os valores inferiores observados nas bordas.

a)

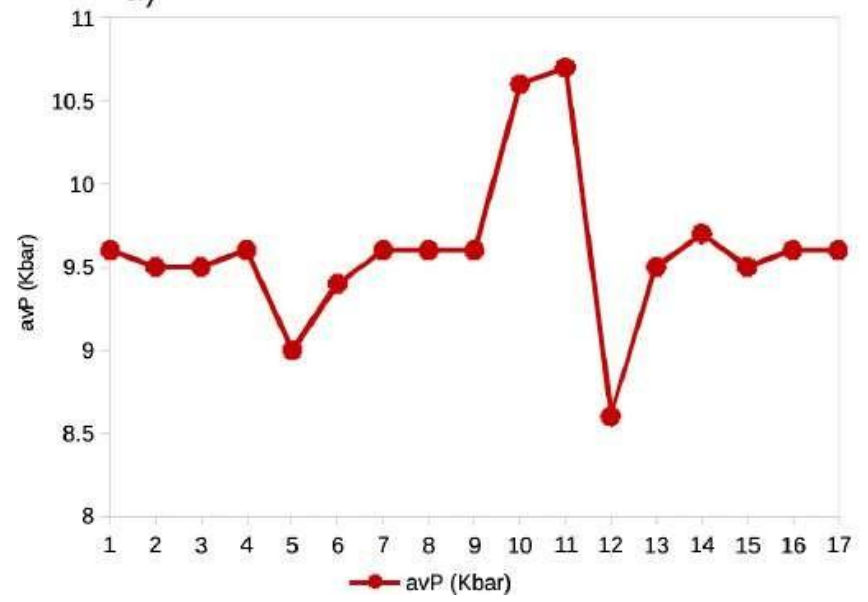

b)

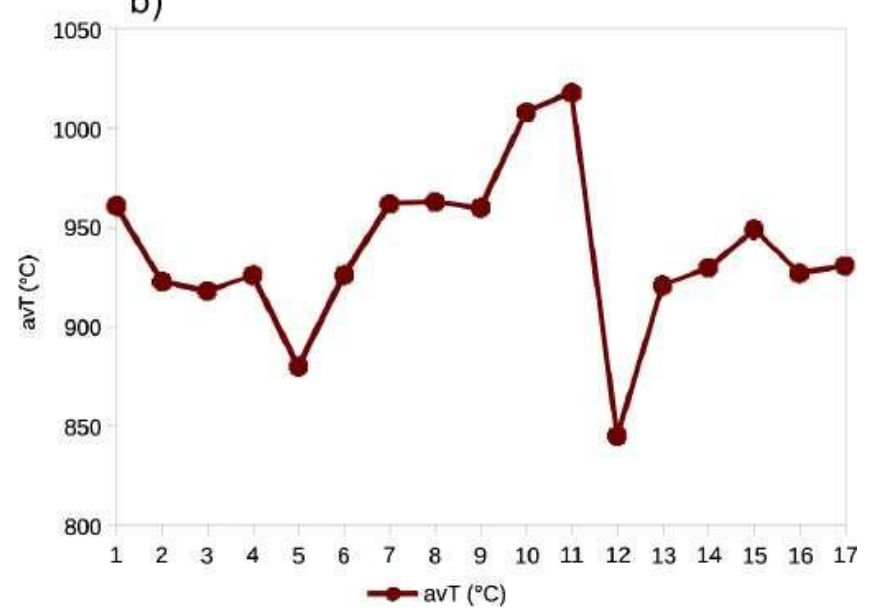

Figura 33: a) Variação das pressões no modo avP com o software THERMOCALC; e b) Variação das temperaturas calculadas no modo avT com o software THERMOCALC.

É difícil conciliar os dados obtidos com os geotermômetros e o geobarômetro convencionais com os dados obtidos por meio do THERMOCALC. Talvez por fazer uso de banco de dados internamente consistente o THERMOCALC não seja tão sensível à variação composicional dos membros finais em equilíbrio quanto os métodos convencionais parecem ser. De fato, Powell \& Holland (2008) orientam aliar os cálculos geotermobarométricos feitos com o THERMOCALC com geotermômetros e geobarômetros convencionais, já que as composições dos membros finais em 
equilíbrio afetam os valores de pressão e temperatura.

A figura 34 mostra a variação da temperatura calculada com o THERMOCALC pelo método avT em relação a variação dos teores das moléculas de almandina, grossulária e andradita. A comparação evidencia que as maiores temperaturas coincidem com os maiores valores da molécula de andradita. Tal constatação é coerente quando se alia esses dados à reação (3) proposta para o granadahedembergita granulito, na qual grossulária e almandina são consumidas durante o metamorfismo para formar anortita e hedembergita. De maneira semelhante, o perfil composicional da grossulária se comporta de maneira oposta à temperatura, ou seja, os maiores valores de temperatura conincidem com os menores valores da molécula de grossulária, o que também faz sentido frente à reação proposta.

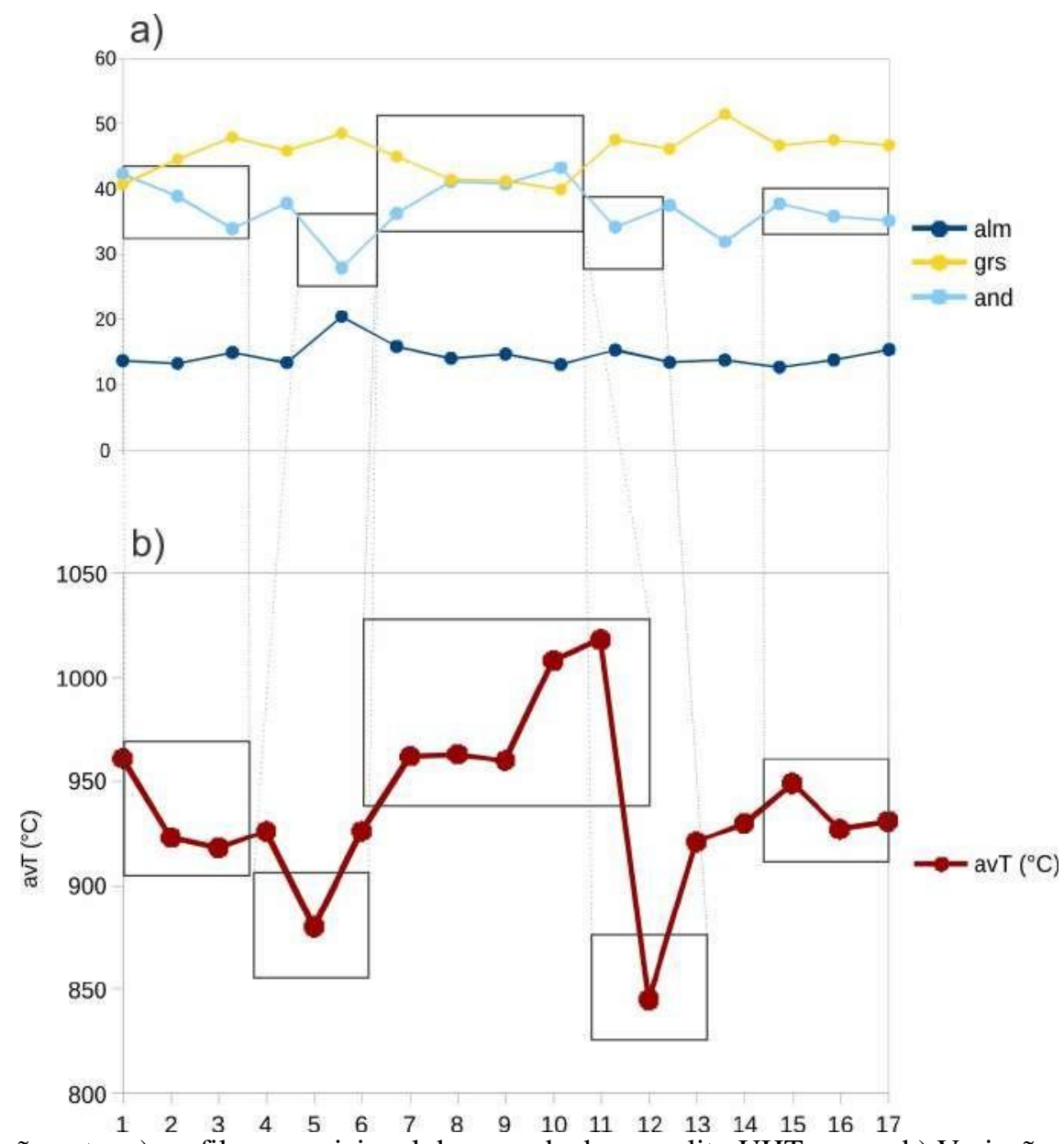

Figura 34: Comparação entre a) perfil composicional da granada do granulito UHT versus b) Variação da temperatura calculada com o THERMOCALC pelo método avT $\left({ }^{\circ} \mathrm{C}\right)$.

\section{Discussão}

\subsection{Estrutura magmática}

As rochas máfico-ultramáficas acamadadas do CD são interpretadas no presente estudo como tendo estratigrafia normal. A arquitetura das rochas do complexo é composta pela Zona Ultramáfica ocupando posição mais central encapsulada pelas Zonas Máfica de Base e de Topo. Tal cenário é 
corroborado por texturas ígneas primárias e evidências mineralógicas e geoquímicas, tais como os teores de An, Fo e En, por exemplo, apresentadas neste estudo. Além disso, supondo-se que processos normais de cristalização fracionada predominaram durante a formação do CD, tanto a sequência de cristalização quanto a variação críptica dos minerais cumuláticos observados dão suporte à hipótese de estratigrafia normal do CD.

Próximo ao Complexo de Damolândia ocorrem outros complexos máfico-ultramáficos, como, por exemplo o de Taquaral (CT), que foi inicialmente interpretado por Silva (1997) como sendo um complexo máfico-ultramáfico acamadado contínuo (até $50 \mathrm{~km}$ de comprimento) que foi submetido a metamorfismo de alto grau e tectonismo associado. No entanto, mapeamentos posteriores de detalhe mostraram ser uma sequência de corpos individuais altamente tectonizados, cercados por gnaisses e granulitos félsicos. Assemelha-se ao $\mathrm{CD}$, com a diferença que lherzolito é mais abundante no CT (evidenciado pelos altos teores de $\mathrm{CaO}$ e $\mathrm{TiO}_{2}$ verificados em peridotitos) enquanto que no $\mathrm{CD}$, prevalece a ocorrência de harzburgito (Della Giustina et al., 2011a). Della Giustina et al. (2011a) sugerem que a sequência de cristalização para o CT é

$$
\begin{gathered}
\text { olivina + cromita } \\
\text { ortopiroxênio + cromita } \\
\text { ortopiroxênio + clinopiroxênio } \\
\text { ortopiroxênio + clinopiroxênio + plagioclásio } \\
\text { ortopiroxênio + clinopiroxênio + plagioclásio + ilmenita }
\end{gathered}
$$

Ao contrário do que é observado no $\mathrm{CD}$ e na sequência de cristalização proposta para esse complexo, a sequência proposta pelos autores para o CT indica cristalização inicial de clinopiroxênio e é semelhante às sequências descritas no Great Dyke e no Complexo de Niquelândia (Della Giustina et al, 2011a).

Ainda dentro do contexto de complexos máfico-ultramáficos que ocorrem no CAI, cerca de 60 km noroeste do Complexo de Damolândia, ocorre o Complexo Americano do Brasil, descrito incialmente por Metago (1978), Nilson (1981) e Nilson et al. (1986) e em detalhe por Mota e Silva (2009) e Mota e Silva et al. (2011). Descrito com mais detalhe no item de geologia regional não cabe aqui repetir o que já foi dito, portanto, cabe apenas ressaltar que o Complexo Americano do Brasil é um complexo máfico-ultramáfico composto pelas sequências norte e sul e com trend $\mathrm{E}-\mathrm{W}$, assim como o CD. Tanto a sequência norte como a sul são consideradas como sendo tectonicamente invertidas e a sequência de cristalização deste complexo é dada por

$$
\begin{gathered}
\text { olivina }+ \text { cromita } \\
\text { olivina }+ \text { ortopiroxênio }+ \text { cromita }
\end{gathered}
$$




$$
\begin{gathered}
\text { clinopiroxênio + ortopiroxênio } \\
\text { ortopiroxênio + plagioclásio + clinopiroxênio } \\
\text { ortopiroxênio + plagioclásio + clinopiroxênio + ilmenita + magnetita }
\end{gathered}
$$

sendo semelhante à sequência de cristalização do Complexo de Taquaral e diferente da do Complexo de Damolândia, já que no CD o clinopiroxênio apresenta cristalização mais tardia.

\subsection{Composição do magma parental}

Técnicas normais de determinação da composição do magma parental em intrusões com boa exposição e pouca alteração (como análise de margens de resfriamento, composição de rocha total, equivalentes extrusivos, diques associados e inclusões de melt) não podem ser empregadas na definição composicional do magma parental das rochas do CD. Portanto, como uma composição direta não pode ser extraída das rochas em questão esta deve ser inferida, principalmente por meio da geoquímica dos minerais cumuláticos e sequência de cristalização da intrusão acamadada. A variação composicional de olivina cumulática (Fo70-72 nas rochas máficas e Fo82-89 nas ultramáficas) é compatível com magma parental de composição moderadamente enriquecida em $\mathrm{MgO}$ ou moderadamente primitivo ou até mesmo, ser resultado de mais de um pulso magmático. Variação composicional críptica da olivina nas rochas ultramáficas sugere "ensanduichamento" composicional dentro da própria Zona Ultramáfica, ou seja, as composições mais primitivas se localizam no centro e as mais fracionadas nas Zonas Máfica de Topo e de Base. Essa variação críptica sugere a existência de câmara magmática dinâmica, sujeita a reinjeções de pulsos magmáticos. Os minerais cumuláticos observados sugerem que a sequência de cristalização foi

$$
\begin{gathered}
\text { olivina + cromita } \\
\text { ortopiroxênio + cromita } \\
\text { ortopiroxênio } \\
\text { ortopiroxênio + plagioclásio } \\
\text { ortopiroxênio + plagioclásio + clinopiroxênio }
\end{gathered}
$$

Essa sequência de cristalização (descrita primeiro por Della Giustina et al., 2011a) no CD é bastante comum como, por exemplo, nos complexos de Bushveld, Serra da Onça. A cristalização do ortopiroxênio anterior à cristalização de clinopiroxênio, conforme foi indicado pela sequência de cristalizaçao sugerida para o $\mathrm{CD}$, é indicativa de que o magma primitivo foi saturado em sílica. Vários artigos anteriores indicam que em vários complexos o ortopiroxênio se cristalizou antes do clinopiroxênio. A assimilação da crosta continental pode ter induzido o enriquecimento de sílica nesses magmas (Campbell, 1985). Os isótopos de O, que serão discutidos em mais detalhe à frente, 
corroboram a hipótese de contaminação crustal. Além disso, valores fortemente negativos de $\varepsilon \mathrm{Nd}$, registrados por Della Giustina et al. (2011a), variando de -3.9 a -26.5 são indicativos de diferentes graus de assimilação crustal durante a ascensão do magma que deu origem ao CD.

Nem sempre é fácil avaliar a significância da contaminação crustal, levando-se em conta apenas os elementos-traço ou dados isotópicos. Como não é possível fazer a avaliação direta da composição do magma parental do Complexo de Damolândia, mesmo com a composição das possíveis rochas contaminantes tendo sido tabulada, um modelo quantitativo do magma parental não é confiável já que, tanto os dados litogeoquímicos quanto os isotópicos podem ser indicativos de fusão de manto litosférico contaminado.

\subsection{Contexto petrotectônico do Complexo de Damolândia}

O Complexo de Damolândia apresentou datações de 670 e 590 Ma (Della Giustina et al., 2011a) o que indica que pode ser relacionado ao terceiro episódio de magmatismo do Arco Magmático de Goiás (AMG), que ocorreu de 660 a 600 Ma, possivelmente como resultado de uma margem continental ativa durante a fase final de formação da Faixa Brasília (Laux et al., 2005; Pimentel, 2016). Estudos recentes sugerem que o CAI, composto por paragranulitos e ortogranulitos, representa um complexo metamórfico composto de protólitos do Grupo Araxá e Arco Magmático de Arenópolis (Piuzana et al., 2003a; Laux et al., 2005). O Arco Magmático de Arenópolis é a parte sul do AMG (dividido em norte e sul pelo Maciço de Goiás), sendo que dados recentes sugerem que a atividade ígnea no AMG ocorreu em três episódios, um entre 900 e 800 Ma, formado em ambiente intraoceânico, um ambiente intraoceânica da série tonalítica, um segundo entre 790 a 786 Ma e o terceiro entre 660 e $600 \mathrm{Ma}$, conforme já mencionado anteriormente, que ocorreu ao longo de uma margem continental ativa no fim da orogenia (Laux et al., 2005; Pimentel, 2016).

O Complexo de Taquaral apresenta idades de 623 a 525 Ma (Della Giustina et al., 2011a) e, assim como para o Complexo de Damolândia, as idades superiores são interpretadas como sendo referentes ao magmatismo. De maneira semelhante, o Complexo Americano do Brasil apresenta idade de 628 Ma (Mota e Silva, 2009; Mota e Silva et al., 2011). Assim como vários outros complexos máfico-ultramáficos da Faixa Brasília se encaixam no terceiro episódio magmático do Arco Magmático de Arenópolis, os complexos de Damolândia, Taquaral e Americano do Brasil também o fazem. Na parte centro-leste do Arco Magmático de Arenópolis, no contato com o Complexo Anápolis-Itauçu, a sequência vulcano-sedimentar Anicuns-Itaberaí está exposta. Esta sequência é formada por anfibolito metavulcânico e metaplutônico, rochas metapelíticas com formações ferríferas de maneira mais restrita, chert, mármore e rochas ultramáficas. Datações por U-Pb recentes sugerem que esta sequência 
possivelmente dá origem à parte do Arco Magmático de Arenópolis formada durante o primeiro episódio magmático da região, de 890 a 800 Ma (Laux et al., 2004; Laux et al., 2005).

Análises petrológicas e minerais, bem como dados isotópicos descritos no presente trabalho são consistentes com o modelo de assimilação da crosta continental antiga durante a ascensão e colocação do magma que gerou o CD. Resultados semelhantes foram reportados para outros complexos, como o de Taquaral e o de Americano do Brasil (Della Giustina et al., 2011a; Mota e Silva, 2009; Mota e Silva et al, 2011), que também sugerem assimilação e contaminação dos complexos máfico-ultramáficos por parte da crosta continental antiga. Independente de como este magma foi gerado, esses dados são condizentes com a ocorrência de grande volume de magmatismo máfico de composição magnesiana primitiva nessa região da Faixa Brasília. Esse contexto geológico de grande volume de magmatismo máfico espacialmente e temporalmente associado com metamorfismo de alto grau, pode corresponder a episódios extensionais dentro do ambiente colisional descrito para a Faixa Brasília. Sugere-se que durante estes momentos extensionais ocorreu a ressurgência da astenosfera quente, tendo como resultado fusão parcial tanto do manto quanto da crosta continental, gerando o magmatismo máfico extensivo verificado nesta porção da Faixa Brasília (Pimentel et al., 1991; Pimentel \& Fuck, 1992; Pimentel et al., 2004; Pimentel, 2016). Com base nos dados geológicos e geocronológicos apresentados tanto para o $\mathrm{CD}$, quanto para os demais complexos máfico-ultramáficos aqui citados, pode se interpretar que o CD formou-se em episódio magmático anterior ao episódio descrito para a Suíte Americano do Brasil e equivalente ao terceiro episódio magmático descrito para o AMG.

A figura 35 evidencia a diferença entre as assinaturas das rochas do CD e do granulito regional a dois piroxênios analisado. Enquanto as rochas máficas e ultramáficas do CD apresentam assinatura de arco continental, o granulito regional a dois piroxênios apresenta assinatura de manto depletado. A assinatura de margem continental é compatível com o CD ter sido formado durante o terceiro estágio de reativação magmática do AMG. 


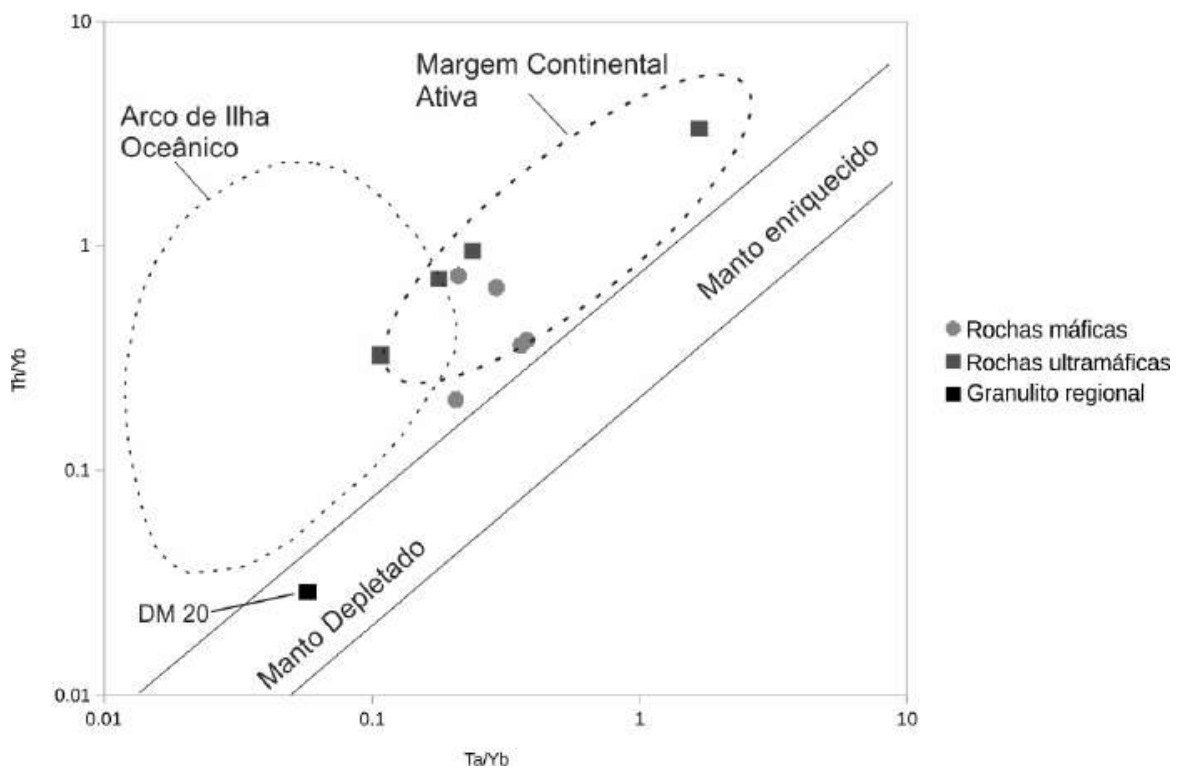

Figura 35: Gráfico das razões $\mathrm{Ta} / \mathrm{Yb}$ versus $\mathrm{Th} / \mathrm{Yb}$ evidenciando a variação nas assinaturas das rochas do Complexo de Damolandia e o granulito regional analisado.

\subsection{Metamorfismo das rochas magmáticas do Complexo de Damolândia}

Assembléias metamórficas de granulação fina verificadas no $\mathrm{CD}$, indicativas de metamorfismo em fácies granulito, parcialmente substituem a mineralogia ígnea primária extensivamente preservada ao longo do CD. Essas porções, verificadas principalmente no gabronorito tardio da Zona Máfica de Topo (amostra DM 16), são compostas por agregados granoblásticos finos de plagioclásio + ortopiroxênio + clinopiroxênio + anfibólios + filossilicatos, indicativos de recristalização sob condições de temperatura alta durante o metamorfismo regional. A amostra DM 18 foi inicialmente interpretada como sendo um granulito regional, mas dados litogeoquímicos, bem como da associação mineralógica, indicam se tratar de gabronorito tardio, semehante à amostra DM 16. Apresenta textura quase totalmente recristalizada e foliação menos pervasiva que a amostra DM 16. A recristalização metamórfica verificada no $\mathrm{CD}$ é heterogênea e, de certa forma, localizada, já que a maior parte das texturas e mineralogias ígneas do CD encontram-se preservadas. A foliação pervasiva verificada nessas porções metamorfizadas é restrita e texturas ígneas primárias podem ser identificadas juntamente com as partes modificadas. O metamorfismo é interpretado como sendo, ao menos em parte, coevo ao magmatismo que gerou o CD (Della Giustina et al., 2011a). A idade de $~ 670$ Ma é compatível com o terceiro episódio magmático do AMG, já mencionado. As rochas do Arco Magmático de Arenópolis, que é parte do AMG, foram submetidas ao metamorfismo em fácies xisto-verde superior e anfibolito, mas retiveram as características geoquímicas e isotópicas principais, indicando a natureza juvenil dos protólitos ígneos (Junges et al., 2002). Já o metamosfismo do CD é interpretado como sendo em fácies 
granulito o que sugere que a fonte de calor que gerou o metamorfismo da região afetou mais significativamente as rochas do $\mathrm{CD}$ e os granulitos em contato com ele, resultando em metamorfismo de mais alto grau. Não tendo sido encontradas evidências de hidrotermalismo no CD, a recristalização metamórfica descrita no complexo é interpretada como sendo resultado de metamorfismo regional que atingiu fácies granulito no complexo e ultra alta temperatura (UHT), de maneira restrita, conforme descrito por Moraes et al., (2002) e Balwin et al., (2005), bem como no presente trabalho. Além disso, texturas e mineralogias metamórficas, verificadas principalmente no gabronorito tardio evidenciam reequilíbrio em alta temperatura, em fácies anfibolito intermediário a superior ou até mesmo granulito.

O granada-hedembergita granulito pode ser interpretado como sendo um skarn, gerado a partir da interação de fluidos magmáticos oriundos do magma que originou o CD com as rochas encaixantes ou como um xenólito. Xenólitos máficos de crosta continental profunda também tem sido descritos com a associação mineralógica granada + clinopiroxênio + plagioclásio \pm quartzo em kimberlitos e diques basálticos (Griffin \& O’Reilley, 1987; Hanchar et al., 1994). Condições de pressão e temperatura nessas rochas podem se sobrepor às condições de granulitos regionais, mas essas condições podem também se estender a condições de pressão e temperatura mais altas, características da transição de alta pressão dos fácies granulito-eclogito (Griffin \& O’Reilly, 1987).

A tabela 6 resume as principais fases minerais observados ao longo do CD, bem como nos granulitos regionais analisados (granulito a dois piroxênios e granada-hedembergita granulito). A tabela reforça a ideia que as porções recristalizadas, onde o metamorfismo heterogêneo superimposto é mais evidente, apresentam fases mineralógicas semelhantes às observadas nas porções onde texturas e mineralogias ígneas estão preservadas. Além disso, a associação mineral observada no xenólito, em especial a hialofana, sugerem a ocorrência de metassomatismo no CD, indicado na tabela 6. 
Tabela 6: Resumo das fases minerais observadas no Complexo de Damolândia, no granulito regional e no granadahedembergita granulito nas porções ígneas preservadas, nas porções recristalizadas e no xenólito que apresenta evidências metassomáticas. $\mathrm{CD}=$ Complexo de Damolândia e $\mathrm{GR}=$ granulito regional.

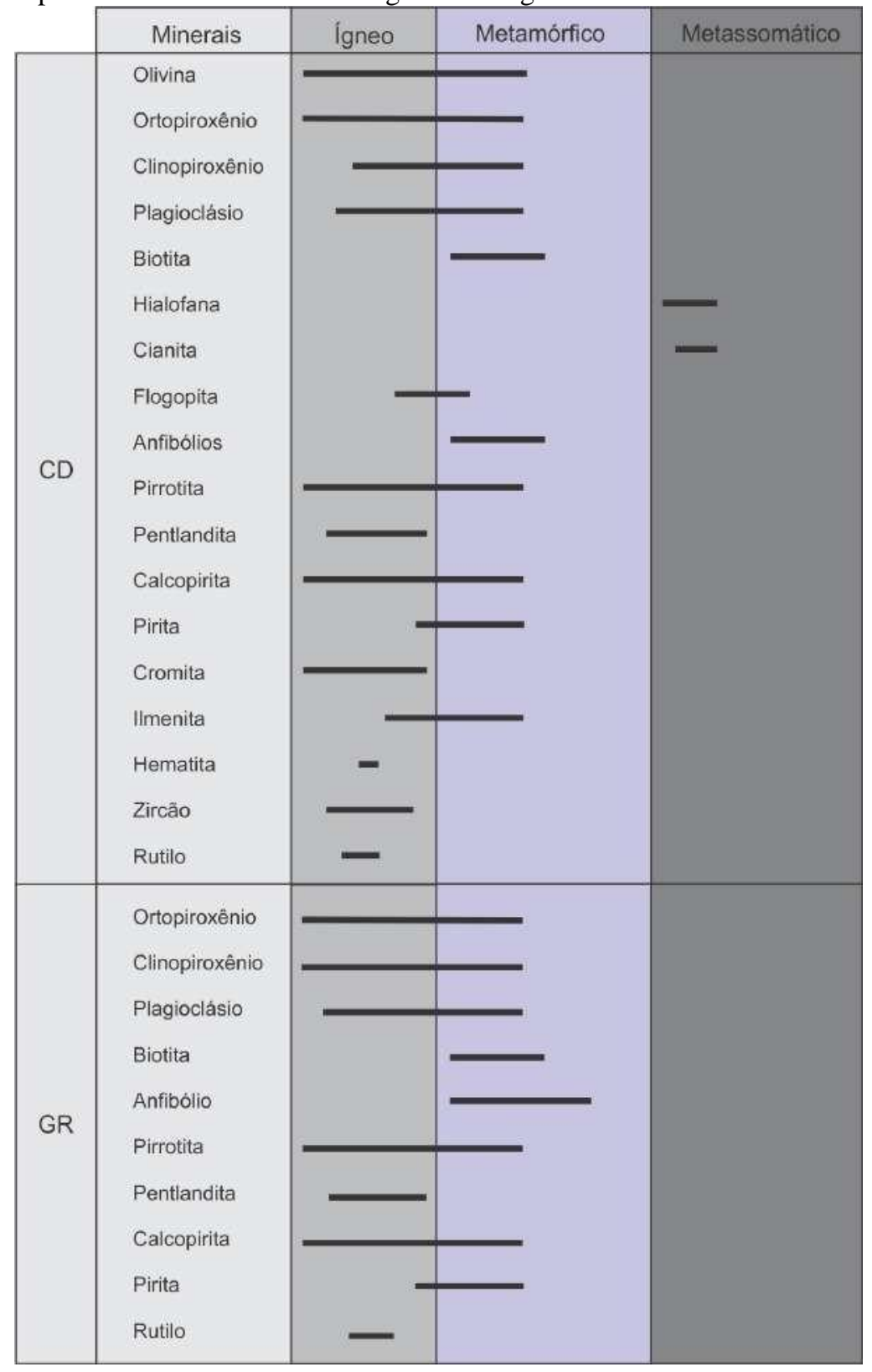

\subsection{Implicações para a evolução da Faixa Brasília}

A presença de granulitos UHT nas proximidades do complexo faz surgir a questão de qual foi a fonte de calor que gerou o gradiente metamórfico observado na região. Datações $\mathrm{U}-\mathrm{Pb}$ em grãos zircões do CD evidenciam idades que foram interpretadas como sendo referentes aos magmatismo máfico que originou o complexo como sendo de aproximadamente $670 \mathrm{Ma}$ e o referente ao metamorfismo superimposto como tendo sido, pelo menos em parte, coevo ao magmatismo (Della Giustina, 2010; Della Giustina et al., 2011a). Magmatismo máfico tem sido proposto como possível 
fonte de gradiente térmico suficiente para geração de granulitos UHT (England \& Richardson, 1977; Ellis, 1980; Wells, 1980; Bohlen, 1987, 1991; Bergantz, 1989). Tal hipótese pode ser especialmente levada em consideração como explicação para geração das rochas UHT consideradas no presente estudo, em especial devido ao fato que granulitos UHT já terem sido investigados e descritos por Moraes et al. (2002) e Baldwin et al. (2005) em regiões próximas ao CD, inseridos no contexto do CAI. Além disso, esses episódios de extensivo magmatismo máfico com metamorfismo de alto grau superimposto podem estar associados a episódios extensionais no ambiente colisional em que a Faixa Brasília se formou, o que possibilitou a ascensão da astenosfera com maior gradiente térmico, resultando na fusão tanto do manto quanto da crosta continental (Pimentel et al., 1991; Pimentel \& Fuck, 1992; Pimentel, 2016). Pimentel (2016) reforça a ideia, em seu trabalho mais recente, que as idades de 650-630 Ma são tidas como sendo representativas do pico do metamorfismo do CAI e também como sendo referentes à colisão final do orógeno do qual a Faixa Brasília se origina.

Evidências isotópicas sugerem que o magmatismo máfico responsável pela cristalização dos corpos associados ao $\mathrm{CD}$ foi concomitante ao metamorfismo de alto grau, registrado nas rochas do Complexo Anápolis-Itauçu. Della Giustina et al. (2012) apresentam valores de $\delta^{18} \mathrm{O}$ de oxigênio consistentes e muito positivos $(8,17 \pm 0,24 \%$; Tabela 6$)$ para a população de zircão do $C D$, enquanto que o granulito regional a dois piroxênios possui assinatura dentro do intervalo mantélico $(5,14 \pm 0,19 \%$; Tabela 6) e, portanto, adequado a protolito máfico. Dessa forma, quando comparados aos dados de U$\mathrm{Pb}$ e isótopos de $\mathrm{Hf}$ obtidos nos mesmos grãos, fica mais uma vez evidente a diferença entre o complexo acamadado e as encaixantes, também de composição máfica (figuras 36 e 37). 
Tabela 7: Valores dos isótopos de O verificados no gabronorito tardio (DM 16) e no granulito regional a dois piroxênios (DM 20) (Della Giustina et al, 2012).

\begin{tabular}{|c|c|c|c|c|c|}
\hline DM-16 (CD) & $\delta 180$ & $\pm \%$ & DM-20 & $\delta 180$ & $\pm \%$ \\
\hline n4127ox_7c1 & 8.40 & 0.17 & $n 4130 o x-06 r$ & 4.79 & 0.19 \\
\hline n4127ox_7c2 & 8.06 & 0.17 & $n 4130 o x-06 c$ & 4.78 & 0.17 \\
\hline n4127ox_7r1 & 7.96 & 0.16 & $n 4130 o x-05 r$ & 5.16 & 0.20 \\
\hline n4127ox_7r2 & 7.81 & 0.16 & n4130ox-05c & 5.10 & 0.19 \\
\hline n4127ox_6r & 7.96 & 0.16 & n4130ox-08r & 4.84 & 0.21 \\
\hline n4127ox_6c & 8.39 & 0.16 & n4130ox-08c & 5.38 & 0.18 \\
\hline n4127ox_4c & 7.97 & 0.17 & $n 4130 o x-11 r$ & 5.99 & 0.18 \\
\hline n4127ox_4r & 8.45 & 0.17 & $n 4130 o x-11 c$ & 5.31 & 0.16 \\
\hline n4127ox_2c & 8.12 & 0.18 & $n 4130 o x-10 c$ & 5.22 & 0.19 \\
\hline n4127ox_2r & 8.15 & 0.17 & n4130ox-10r & 5.31 & 0.31 \\
\hline n4127ox_14c1 & 8.46 & 0.16 & & & \\
\hline n4127ox_14c2 & 8.38 & 0.18 & & & \\
\hline n4127ox_14r & 8.07 & 0.17 & & & \\
\hline n4127ox_15c & 7.88 & 0.18 & & & \\
\hline n4127ox_13c & 8.56 & 0.19 & & & \\
\hline
\end{tabular}

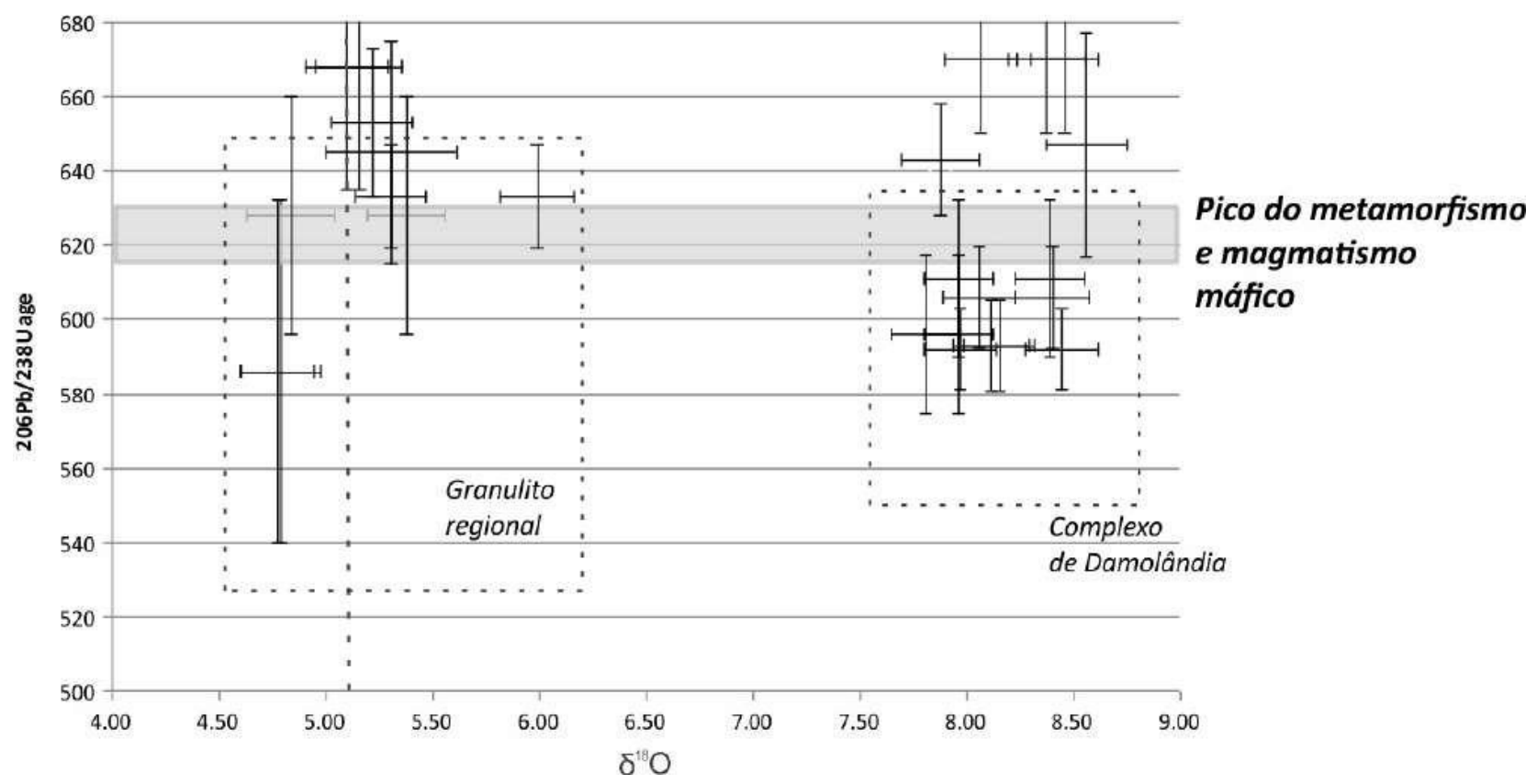

Figura 36: Variações das datações de U-Pb para as rochas do $\mathrm{CD}$ e os granulitos máficos regionais (gráfico confeccionado com os dados publicados por Della Giustia et al., 2012). 


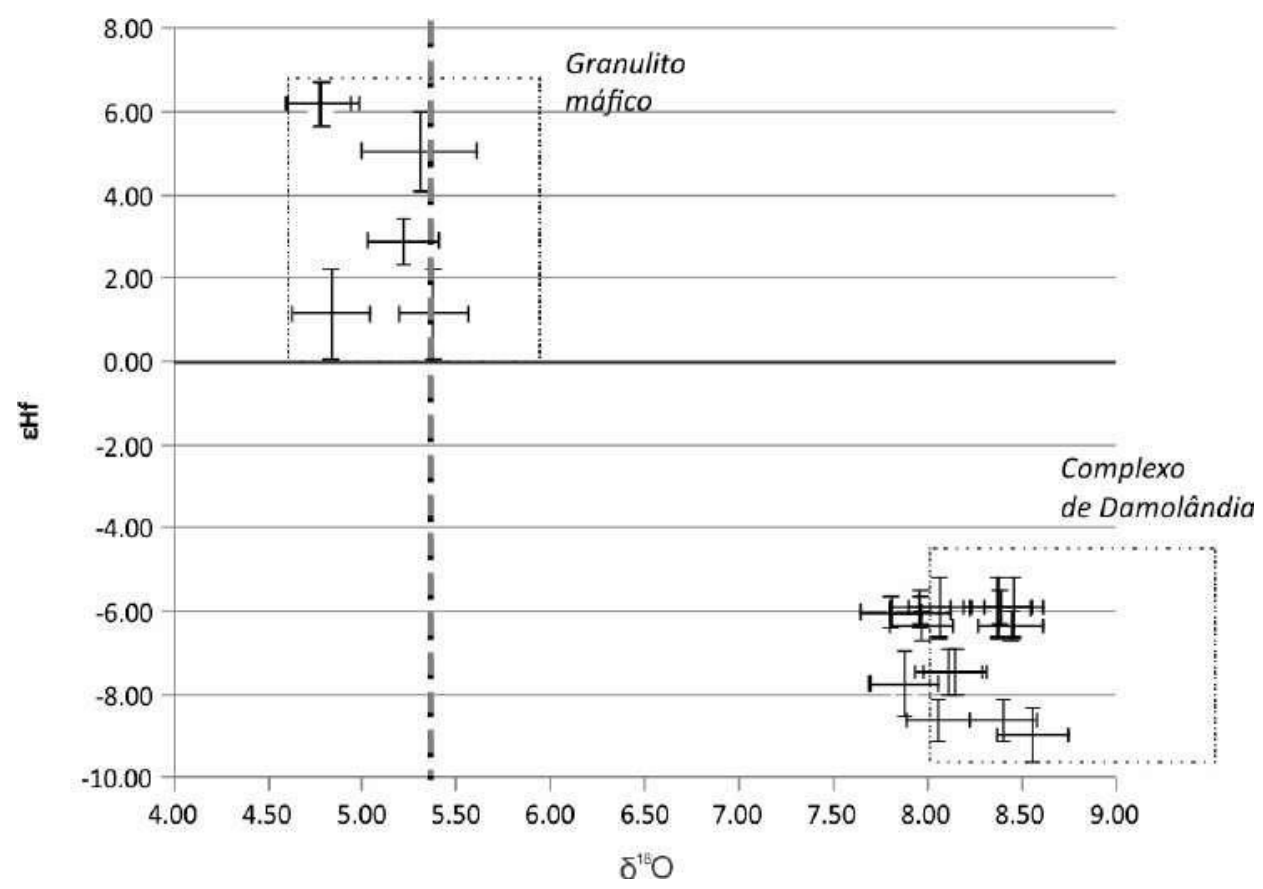

Figura 37: Gráfico de variação dos valores de $\mathrm{Hf}$ observados nas rochas do $\mathrm{CD}$ e nos granulitos máficos regionais descritos no presente trabalho (gráfico confeccionado com os dados publicados por Della Giustina et al., 2012).

O fracionamento isotópico de oxigênio, assim como de outros isótopos estáveis, ocorre sob condições de baixas temperaturas e, portanto, pode ser explicado a partir da reciclagem de material de origem metassedimentar. Assim, assinaturas muito positivas em zircão de origem mantélica, similares às descritas no $\mathrm{CD}$, não seriam naturalmente observadas e processos adicionais se fariam necessários, a saber: i) recristalização, que promove a modificação da assinatura isotópica primária do zircão; ii) origem a partir de fusões de manto metassomatizado, acima da zona de subducção; e iii) interação entre fluidos magmáticos e metamórfico-metassomáticos durante a cristalização do grão.

Della Giustina et al. (2012) discutem que, apesar de o zircão do CD apresentar texturas internas típicas de recristalização, a assinatura isotópica é constante em toda a população de zircão e que não exibe relação com núcleos ou bordas recristalizadas durante o metamorfismo e, portanto, interpretam que os valores de $\delta^{18} \mathrm{O}$ obtidos ainda reflitam a assinatura primária dos grãos.

Por outro lado, a hipótese de origem a partir de fusões de manto metassomatizado em zona de subducção pode ser discutida frente aos dados litogeoquímicos apresentados neste trabalho, que apesar de sugerirem cristalização sintectônica para o $\mathrm{CD}$, revelam origem a partir de magmas de composição toleítica, moderadamente primitivos, sem enriquecimento significativo em elementos HFSE ou LILE. Assim, frente ao exposto, seria esperada uma assinatura isotópica compatível, com $\delta^{18} \mathrm{O}$ em zircão próximo do valor mantélico. Com isso, a assinatura isotópica observada nos cristais de zircão do $\mathrm{CD}$ pode ser explicada a partir de interação entre o magma toleítico com um componente de $\delta^{18} \mathrm{O}$ pesado 
durante a cristalização ígnea da intrusão. Os paragranulitos do CAI apresentam assinatura isotópica de Nd (Della Giustina et al., 2011a, 2012) similar aos valores obtidos no CD. Assim, fluidos e/ou fusões oriundas de reações metamórficas nesses litotipos durante metamorfismo de alto grau poderiam contribuir para os valores elevados de $\delta^{18} \mathrm{O}$ observados e, portanto, magmatismo máfico e metamorfismo de alto grau seriam concomitantes no CAI.

O granulito UHT descrito e modelado pode ter sido formado a partir de metamorfismo de contato. A amostra foi coletada adjacente às rochas máficas do CD e o granulito máfico regional a dois piroxênios aqui já descrito. A associação mineralógica exótica desse granulito, em relação às demais rochas do $\mathrm{CD}$, sugere que essa rocha se formou a partir da interação de um fluido magmático evoluído resultante da ascensão do magma que gerou o $\mathrm{CD}$ na crosta, gerando a mineralogia rica em $\mathrm{Fe}$ e $\mathrm{Ca}$ observada. As dimensões restritas do corpo amostrado, bem como das condições P e T calculadas para essa rocha no presente trabalho, reforçam a ideia de que o metamorfismo alcançou condições UHT pontualmente em relação às rochas do $\mathrm{CD}$.

A tabela 8 apresenta resumo das associações UHT verificadas no CAI e descritas na bibliografia e no presente trabalho. Apesar do presente trabalho apresentar uma mineralogia que não é diagnóstica de metamorfismo UHT, diferente do que é descrito por Moraes et al. (2002) e Baldwin et al. (2005), o modelamento realizado nesse trabalho mostra condições similares ao que é descrito para o CAI.

Dados U-Pb de $\sim 670$ Ma obtidos por Della Giustina et al. (2011a) em zircão dos complexos de Damolândia e Taquaral e em rutilo de fácies granulito em paragranulito (Miranda et al., 2015) caracterizariam a real idade do pico metamórfico na Faixa Brasília (Figura 38).

Datações de $\sim 634 \mathrm{Ma}$ (Ar-Ar em hornblenda) e $\sim 628 \mathrm{Ma}$ (U-Pb em rutilo de fácies xisto verde) marcam, por outro lado, o reequilíbrio metamórfico no CAI, e que por sua vez está associado a outro episódio magmático máfico, responsável pela cristalização das intrusões acamadados da Suíte Americano do Brasil (Mota e Silva et al., 2011). A seta em segundo plano na figura 38 indica a trajetória P-T-t de resfriamento isobárico da Faixa Brasília, semelhante ao que foi apresentado por Moraes et al. (2002). 
Tabela 8: Resumo das associações minerais UHT descritas por Moraes et al. (2002), Baldwin et al. (2005) e no presente trabalho e condições P-T calculadas para as respectivas associações.

\begin{tabular}{|l|c|c|}
\hline \multicolumn{1}{|c|}{ associação mineral } & Condições P-T & Referência \\
\hline $\begin{array}{l}\text { Safirina + quartzo em grt-opx-sil } \\
\text { granulitos }\end{array}$ & $\sim 10$ kbar e $1030-1050{ }^{\circ} \mathrm{C}$ & Moraes et al (2002) \\
\hline $\begin{array}{l}\text { Granada }+ \text { ortopiroxênio + } \\
\text { sillimanita + quartzo em } \\
\text { granulitos rico em Mg e Al }\end{array}$ & 9 kbar e $1000{ }^{\circ} \mathrm{C}$ & Baldwin et al (2005) \\
\hline $\begin{array}{l}\text { Granada + clinopiroxênio } \\
\text { plagioclásio em granada- } \\
\text { hedembergita granulito }\end{array}$ & $\sim 9,6 \mathrm{kbar} \mathrm{e} \sim 940{ }^{\circ} \mathrm{C}$ & Presente trabalho \\
\hline
\end{tabular}

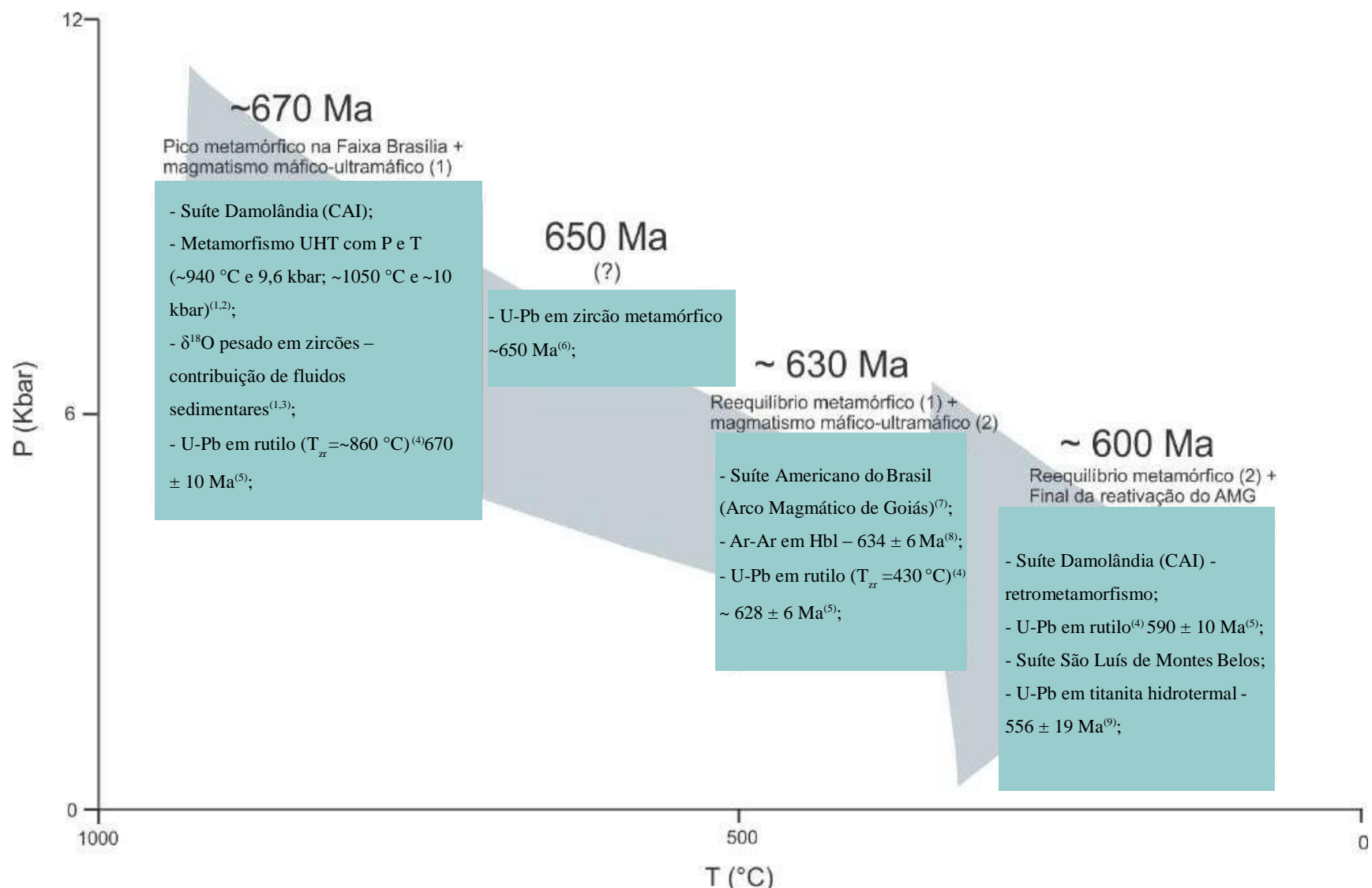

Figura 38: Resumo das idades e temperaturas registradas no Complexo Anápolis-Itauçu e no Complexo de Damolândia. 1 o presente trabalho; 2 - Moraes et al. (2002); 3 - Della Giustina et al. (2012); 4 - Moraes (2013); 5 - Miranda et al. (2015);6 - Piuzana et al. (2003b); 7 - Mota e Silva et al. (2011); 8 - Della Giustina et al. (em preparação); 9 - Macedo (2016). 


\section{IV - CONCLUSÕES}

As conclusões alcançadas no presente estudo são enunciadas abaixo:

- O Complexo de Damolândia faz parte de um grupo de intrusões máfico-ultramáficas localizadas no CAI que se associa ao episódio final da orogania. Apresenta texturas e mineralogias ígneas primárias predominantemente preservadas, o que permite o estudo tanto do aspecto magmático do complexo quanto do metamorfismo superimposto.

- A variação críptica observada nos teores de Fo, En e An, distribuídos ao longo da estratigrafia do complexo, sugere ao menos um episódio de recarga da câmara. Os teores de Fo82-89 das rochas ultramáficas sugerem magma parental primitivo para o $\mathrm{CD}$;

- Sulfetos observados no CD ocorrem disseminados ao longo de todo o complexo e apresentam mineralogia MSS típica, com cristalização de pirrotita predominando sobre pentlandita, calcopirita e pirita. Pentlandita foi observada apenas como exsoluções (flames) nos grãos de pirrotita, não tendo sido observado qualquer grão individualizado. Óxidos também ocorrem de maneira disseminada ao longo do $\mathrm{CD}$, predominando nas rochas ultramáficas (cromita) e no gabronorito tardio (ilmenita). Pirita é interpretada como sendo tardia, devendo-se à recristalização do complexo;

- O granada-hedembergita granulito ou granulito UHT, amostra DM-19, coletado no contato com as rochas do $\mathrm{CD}$ com granulitos máficos a dois piroxênios, cristalizou-se em condições estimadas de temperatura de $\sim 940^{\circ} \mathrm{C}$ e pressão de $\sim 9,6$ kbar. Mesmo a mineralogia dessa rocha não sendo diagnóstica de condições de UHT, os valores obtidos de temperatura e pressão com geotermobarômetros convencionais e com o THERMOCALC inserem a paragênese observada no campo de metamorfismo de temperatura ultra-alta (UHT);

- O granulito UHT apresenta mineralogia exótica às demais rochas do CD e pode ser classificado como um skarn, resultante da interação de fluidos magmáticos evoluídos, oriundos da formação do $\mathrm{CD}$, com as rochas encaixantes ou então interpretado como sendo xenólito máfico de crosta profunda. A mineralogia observada no granulito UHT já tem sido descrita na literatura como sendo possível diagnóstica da transição entre fácies granulito-eclogito;

- Uma rocha de composição quartzo-aluminosa, interpretada como possível xenólito foi descrita na transição da Zona Ultramáfica para a Zona Máfica de Base e os cristais de feldspato potássico observados nessa porção apresentam teores da molécula de celsiana na ordem de $11 \%$ sendo, portanto, classificados como hialofana. Tal composição rica em Ba é evidência da atuação de processo metassomático no $\mathrm{CD}$, possivelmente concomitante à intrusão, tendo em vista o aspecto granoblástico e a paragênese da hialofana com minerais indicativos de pressões 
e temperaturas elevadas como, por exemplo, cianita;

- As rochas máficas do CD apresentam maior concentração de elementos traço, indicativa da natureza mais fracionada dessas rochas. Anomalias negativas de Zr, Y e Th são indicativos de zicão como fase acessória e a anomalia negativa de Nd corrobora a contaminação por parte das encaixantes. As anomalias positivas de Ce refletem a interação dessas rochas com fluidos de origem metassedimentar, o que é corroborado pelos valores observados para os isótopos de O;

- Valores de ${ }^{18} \mathrm{O}$ indicam contaminação por parte das encaixantes durante a ascensão do magma parental que gerou o CD na crosta continental;

- O magmatismo máfico que originou o CD pode ser associado ao início da reativação magmática do Arco Magmático de Arenópolis, desenvolvido em ambiente de arco continental. Os dados apresentados sugerem que o magma parental do CD ascendeu durante um período extensional, que resultou na ascensão da astenosfera com um gradiente geotérmico alto, acarretando a fusão parcial do manto e da crosta continental e consequente metamorfismo UHT de algumas porções das rochas encaixantes na região do $\mathrm{CD}$, a exemplo do granada-hedembergita granulito descrito no presente trabalho.

Agradecimentos

O presente estudo teve o apoio financeiro do CNPq (Conselho Nacional de Desenvolvimento Científico e Tecnológico). Um agradecimento especial deve ser dado aos funcionários do Laboratório de Microssonda da Universidade de Brasília, cuja disposição e paciência possibilitaram as análises apresentadas no presente trabalho. À orientadora Professora Dr(a). Maria Emília Schutesky Della Giustina, cuja orientação e disponibilidade facilitaram a confecção do presente estudo.

\section{Referências}

AI, Y., 1994. A revision of the garnet-clinopyroxene $\mathrm{Fe}^{+2}-\mathrm{Mg}$ exchange geothermometer. Contribution to Mineralogy and Petrology, 115, 467-473.

BALDWIN, J. A., POWELL, R., BROWN, M., MORAES, R. FUCK, R. A., 2005. Modelling of mineral equilibria in ultrahigh-temperature metamorphic rocks from the Anápolis-Itauçu Complex, Central Brazil. Journal of Metamorphic Geology, 23: 511-531.

BALDWIN, J. A., BROWN, M., 2008. Age and duration of ultra high temperature metamorphism in the Anápolis-Itauçu Complex, Southern Brasília Belt, Central Brazil - constraints from U$\mathrm{Pb}$ geochronology, mineral rare earth element chemistry and trace-element $\quad$ thermometry. 
Journal of Metamorphic Geology 26: 213-233

BARNES, S. J., NALDRETT, A. J., GORTON, M. P., 1985. The origin of the fractionation of platinum-group elements in terrestrial magmas. Chem. Geol 53: 303-323.

BARNES, S. J., 1986. The effect of trapped liquid crystallization on cumulus mineral compositions on layered intrusions. Contributions to Mineralogy and Petrology, 93, 524-531.

BERGANTZ, G. W., 1989. Underplatting and partial melting: implications for melt generation and extraction. Science, 245, 1093-1095.

BERMAN, R. G., 1988. Internally-consisting thermodynamic data for minerals in the system $\mathrm{Na}_{2} \mathrm{O}-$ $\mathrm{K}_{2} \mathrm{O}-\mathrm{CaO}-\mathrm{MgO}-\mathrm{FeO}-\mathrm{Fe}_{2} \mathrm{O}_{3}-\mathrm{Al}_{2} \mathrm{O}_{3}-\mathrm{SiO}_{2}-\mathrm{TiO}_{2} \mathrm{H}_{2} \mathrm{O}-\mathrm{CO}_{2}$. Journal of Petrology, 29, 445-522.

BOHLEN, S. R., 1987. Pressure-temperature time paths and a tectonic model for the evolution of granulites. Journal of Geology, 95, 617-632.

BOHLEN, S. R., 1991. On the formation of granulites. Journal of Metamorphic Geology, 9, 223- 229.

CAMPBELL, I. H., 1985. The difference between oceanic and continental tholeiites: a fluid dynamic explanation. Contrib. Mineral. Petrol. 91, 37-43.

CAMPOS NETO, M. C., CABY, R., 2000. Lower crust extrusion and terrane accretion in the Neoproterozoic nappes of southeast Brazil. Tectonics, 19, 669-687.

COOKE, R. A., O'BRIEN, P.J., 2001. Resolving the relationship between high P-T rocks and gneisses in collisional terranes: an example from the Gföhl gneiss-granulite association in the Moldanubian Zone, Austria. Lithos, 58, 33-54.

DARDENNE, M. A., 2000. The Brasília fold belt. In: Cordani, UG, Milani EJ, Thomaz Filho A, Campos DA (Eds.). Tectonic Evolution of South America. 31St International Geological Congress, Rio de Janeiro 231-263.

DELlA GIUSTINA, M. E. S., 2010. Geocronologia e Significado Tectônico de Rochas Máficas de Alto Grau Metamórfico da Faixa Brasília. Tese de Doutorado nº 101, Universidade de Brasília.

DELlA GIUSTINA, M. E. S., PIMENTEL, M. M., FERREIRA FILHO, C. F., HOLLANDA, M.

H. B. M, 2011a. Dating coeval mafic magmatism and ultrahigh temperature metamorphism in the Anápolis-Itauçu Complex, Central Brazil. Lithos 124, 82-102.

DElla GiUStinA, M. E. S., PIMENTEL, M. M., FERREIRA FILHO, C. F., FUCK, R. A., 
ANDRADE, S., 2011b. U-Pb-Hf-trace element systematics and geochronology of zircon from granulite facies metamorphosed mafic-ultramafic layered complex in Central Brazil. Precam. Res. 189,176-192.

DELLA GIUSTINA, M. E. S., PIMENTEL, M. M., FERREIRA FILHO, C. F., WHITEHOUSE, M., 2012. Assinatura isotópica de $\mathrm{O}$ em zircão de complexos máficos-ultramáficos acamadados e implicações para a evolução da Faixa Brasília. Anais do $46^{\circ}$ Congresso Brasileiro de Geologia.

ELLIS, D. J., GREEN, D. H., 1979. An experimental study of the effect of Ca upon garnetclinopyroxene Fe-Mg exchange equilibria. Contributions to Mineralogy and Petrology, 71, 1322.

ELLIS, D. J., 1980. Osumilite-saphirine-quartz granulites from Enderby Land, Antarctica: P-T conditions of metamorphism, implications for garnet-cordierite equilibria and the evolution of deep crust. Contrib. To Mineralogy and Petrology, 74, 201-210.

ENGLAND, P. C., RICHARDSON, S. W., 1977. The influence of erosion upon the mineral facies of rocks from different metamorphic environments. Journal of the Geological Society, London, 134, 201-213.

ESSENE, E. J., 1989. The current status of thermobarometry in metamorphic rocks. In: "Evolution of metamorphic belts”, S. R. Daly, R. Sliff, B. W. D. Yardley, (Eds.) Geol. Soc. Spec. $\quad$ Paper, $43,1-44$.

ESSENE, E. J., CLAFLIN, C. L., GIORGETTI, G., MATA, P. M., PEACOR, D. R., ÁRKAI, P., RATHMELL, M. A., 2005. Two-, three- and four-feldspar assemblages with hyalophane and celsian: implications for phase equilibra in $\mathrm{BaAl}_{2} \mathrm{Si}_{2} \mathrm{O}_{8}-\mathrm{CaAl}_{2} \mathrm{Si}_{2} \mathrm{O}_{8}-\mathrm{NaAlSi}_{3} \mathrm{O}_{8}-\mathrm{KalSi}_{3} \mathrm{O}_{8}$. Eur. Journal Mineral. 17, 515-535.

FERREIRA FILHO, C. F., NALDRETT, A. J., GORTON, M. P., 1998. REE and pyroxene compositional variation across the Niquelêndia layered intrusion, Brazil: petrological and metallogenetic implications. Appl. Earth Sci. (Trans. Inst. Min. Metall. B) 107, 1-22.

FROST, B. R., 1975. Contact metamorphism of serpentinite, chloritic black-wall and rodingite at Paddy-go-Easy pass, Central Cascades, Washington: Journal of Petrology, v. 16, p. 272-313. green, d. h., 1969. Mineralogy of two Norwegian eclogites. In: Contributions to physicochemical petrology (in Russian). Khorzinskii volume, vol. 1, 37-44.

GREEN, D. H., 1969. Mineralogy of two Norwegian eclogites. In: Contributions to physico-chemical petrology (in Russian), 1, 37-44.

HARLEY, S. L., 1989. The origins of granulites: a metamorphic perspective. Geological Magazine, 
126(3), 215-247.

HARLEY, S. L., HENSEN, B. J., 1990. Archean and Proterozoic high-grade terranes of East Antarctica $\left(40-80^{\circ} \mathrm{E}\right)$ : a case study of diversity in granulite facies metamorphism. In: Ashworth, J. R., \& Brown, M. (Eds.) High Temperature Metamorphism and Crustal Anatexis. London: Unwin Hyman, 320-370.

HOllandA, M. H. B. M., PIMENTEL, M. M., ARMSTRONG, R., 2003. Isotopic and geochronological constraints for the origin of syn- to post- mafic magmatism and crustal remelting in the Brasília Belt, Central Brazil. In: Extended abstracts, IV SSAGI, Salvador, 1941197.

HOLLAND, T. J. B., POWELL, R., 2011. An improved and extended internally consistent termodynamic dataset for phases of petrological interest, involving a new equation of state for solids. Journal of Metamorphic Geology 29, 333-383.

JUNGES, S. L., PIMENTEL, M. M., MORAES, R., 2002. Nd isotopic study of the Neoproterozoic Mara Rosa Arc, Central Brazil: implications for the evolution of the Brasília Belt. Prec Res 117: 101-118.

KELSEY, D. E., WHITE, R. W., HOLlAND, T. J. B., POWELL, R., 2004. Calculated phase equilibria in $\mathrm{K}_{2} \mathrm{O}-\mathrm{FeO}-\mathrm{MgO}-\mathrm{Al}_{2} \mathrm{O}_{3}-\mathrm{SiO}_{2}-\mathrm{H}_{2} \mathrm{O}$ for saphirine-quartz-bearing mineral assemblages. Journal of Metamorphic Geology, 22, 559-578.

LAUX, J. H., 2004. Evolução do Arco Magmático de Goiás com base em dados geocronológicos U$\mathrm{Pb}$ e Sm-Nd. Tese de Doutorado, Universidade de Brasília, Brasília.

LAUX, J. H., PIMENTEL, M. M., DANTAS, E. L., ARMSTRONG, S. A., JUNGES, S. L., 2005. Two Neoproterozoic crustal accretion events in the Brasília Belt, Central Brazil. Journal of South American Earth Sciences 18: 183-198.

MACEDO, H. A. O., 2016. Mineralogia e petrologia do depósito hidrotermal de vermiculita de São Luís de Montes Belos, Arco Magmático de Goiás. Dissertação de Mestrado, Instituto de Geociências, Universidade de Brasília, 101 p.

METAGO, 1978. Complexo máfico ultramáfico de Americano do Brasil. Relatório de Pesquisa DNPM, unpublished.

MIRANDA, A. C. R., DELLA GIUSTINA, M. E. S., 2015. Datação U-Pb em zircão e U-Th/He em apatitas e implicações para a evolução do Complexo Anápolis-Itauçu, Goiás. Anais do $47^{\circ}$ Congresso Brasileiro de Geologia.

MOECHER, D. P., ESSENE, E. J., ANOVITZ, L. M., 1988. Calculation and application of clinopyroxene-garnet-plagioclase-quartz geobarometers. Contrib. Mineral. Petrol., 100, 92- 
106.

MORAES, R., FUCK, R. A., 2000. Ultrahigh-temperature metamorphism in Central Brazil: the Barro Alto Complex. Journal of Metamorphic Geology, 18, 345-358.

MORAES, R., BROWN, M., FUCK, R. A., CAMARGO, M. A., LIM, T. M., 2002.Characterization and P-T evolution of the melt-bearing ultrahigh temperature granulites: an example from the Anápolis-Itauçu Complex of the Brasília fold belt, Brazil, Journal of Petrology, 43(9), 16731705.

MORAES, R., FUCK, R. A., PIMENTEL, M. M., GIOIA, S. M. C. L., HOLLANDA, M. H. B.M., ARMSTRONG, R., 2006. The bimodal rift-related volcanossedimentary sequence in Central Brazil: Mesoproterozoic extension and Neoproterozoic metamosphism. J. South Amer. Earth Sci. 20, 287-301.

MOTA E SILVA, J., 2009. O Complexo máfico-ultramáfico acamadado de Americano do Brasil e sua mineralização de Ni-Cu-Co. Diss de mestrado 257, 86p.

MOTA E SILVA, J., FERREIRA FILHO, C. F., BÜHN, B., DANTAS, E. L., 2011. Geology, petrology and geochemistry of the Americano do Brasil layered intrusion, Central Brazil, and its $\mathrm{Ni}-\mathrm{Cu} \quad$ sulfide deposits. Miner Deposita, 46: 57-90.

NEWTON, R. C., \& PERKINS, D., 1982. Thermodynamic calibration of geobarometers based on the assemblage garnet-plagioclase-orthopyroxene (clinopyroxene)-quartz. American Mineralogist, 67, 203-222.

NILSON, A. A., 1981. The nature of Americano do Brasil mafic-ultramafic complex and associated sulfide mineralization, Goiás, Brazil. PhD thesis, University of Western Ontario 460p.

NILSON, A. A., SANTOS, M. M., CUBA, E. A., SÁ, C. M. G., 1986. Jazida de níquel, cobre e cobalto de Americano do Brasil, Goiás. In: Schobbenhaus C, Coelho CES (Eds.) Principais Depósitos Minerais do Brasil II: 257-273.

PATTISON, D. R. M., NEWTON, R. C., 1989. Reversed experimental calibration of the garnetclinopyroxene Fe-Mg exchange thermometer. Contribution to Mineralogy and Petrology, 101, 87-103.

PIMENTEL, M. M., HEAMAN, L., FUCK, R. A., 1991. Zircon and sphene Pb-U geochronology of Upper Proterozoic volcanic-arc rocks units from southwest Goiás, Central Brazil. Journal of South American Earth Sciences 4: 329-339.

PIMENTEL, M. M., FUCK, R. A., 1992. Neoproterozoic crustal accretion in Central Brazil. Geology 20: 375-379. 
PIMENTEL, M. M., WHITEHOUSE, M. J., VIANA, M. G., FUCK, R. A., MACHADO, N., 1997.

The Mara Rosa arc in the Tocantins Province: further evidence for Neoproterozoic crustal accretion in Central Brazil. Prec Res 81: 299-310.

PIMENTEL, M. M., FUCK, R. A., JOST, H., FERREIRA FILHO, C. F., ARAÚJO, S. M., 2000. The basement of the Brasília Fold Belt and the Goiás Magmatic Arc. In: Cordani UG, Milani EJ, Thomaz Filho A, Campos DA (Eds.) The Tectonic Evolution of South America, Rio de Janeiro. Proceedings of the 31st International Geological Congress 195-229.

PIMENTEL, M. M., FERREIRA FILHO, C. F., ARMSTRONG, R. A., 2004. SHRIMP U-Pb and

Sm-Nd ages of the Niquelândia layered complex: Meso (1.25 Ga) and Neoproterozoic

Ga) extensional events in central Brazil. Precambrian Research, 132: 133-153.

PIMENTEL, M. M., RODRIGUES, J. B., DELlA GIUSTINA, M. E. S, JUNGES, S. L., MATTEINI, M., 2011. The tectonic evolution of the Neoproterozoic Brasília belt, Central Brazil, based on SHRIMP and LA-ICPMS U-Pb sedimentary provenance data: a review. Journal of South America Earth Sciences, 31: $345-357$.

PIMENTEL, M. M., 2016. The tectonic evolution of the Neoproterozoic Brasília Belt, Central Brazil: a geochronological and isotopic approach. Brazilian Journal of Geology, 46, 67-82.

PIUZANA, D., PIMENTEL, M. M., FUCK, R. A., ARMSTRONG, R., 2003a Neoproterozoic granulite facies metamorphism and coeval magmatism in the Brasília Belt, Central Brazil: regional implications of the new SHRIMP U-Pb and Sm-Nd data. Precambrian Research, 125, 245-273.

PIUZANA, D., PIMENTEL, M. M., FUCK, R. A., ARMSTRONG, R., 2003b. SHRIMP U-Pb and Sm-Nd data for the Araxá Group and associated magmatic rocks: constraints for the age of sediments and geodynamic context of the southern Brasília Belt, central Brazil. Precambrian Research, 125, 139-160.

POWELL, R., HOLLAND, T. J. B., 1988. An internally consistent thermodynamic dataset with uncertainties and correlations: 3. Application methods, worked examples and a computer program. Journal of Metamorphic Geology, 6, 173-204.

POWELL, R., HOLLAND, T. J.B., 1994. Optimal geothermometry and geobarometry. American Mineralogist, 79, 120-133.

POWELL, R., HOLLAND, T. J. B., WORLEY, B., 1998. Calculating phase diagrams involving solid solutions via non-linear equations, with examples using THERMOCALC. Journal of Metamorphic Geology. 16, 577-588.

POWELL, R., HOLLAND, T. J. B., 2008. On thermobarometry. J. of Metamorphic Geology, 26, 155- 
179.

POWELL, R., HOLLAND, T. J. B., 2011. An improved and extended internally consistent thermodynamic dataset for phases of petrological inetrest, involving a new equation of state for solids. Journal of Metamorphic Geology, 29(3), 333-383.

RAHEIM, A., GREEN, D. H., 1974. Experimental determination of the temperature and pressure dependence of the $\mathrm{Fe}-\mathrm{Mg}$ partition coefficient for coexisting clinopyroxene and garnet. Contibutions to Mineralogy and Petrology, 48, 179-203.

RAVNA, E. K., 2000. The garnet-clinopyroxene $\mathrm{Fe}^{+2}-\mathrm{Mg}$ geothermometer: an updated calibration. Journal of Metamorphic Geology, 18, 211-219.

SEER, H. J., DARDENNE, M. A., PIMENTEL, M. M., FONSECA, M. A. F., MORAES, L .C., 2000. O Grupo Ibiá na sinforma de Araxá: um terreno tectonoestratigráficoligado à evolução de arcos magmáticos. Rev. Bras. Geociências, 30(4), 737-744.

SEER, H. J., BROD, J. A., FUCK, R. A., PIMENTEL, M. M., BOAVENTURA, G. R., DARDENNE, $\quad$ M. A., 2001. O Grupo Araxá em sua área-tipo. Fragmento de crosta oceânica Neoproterozóica na Faixa de Dobramentos Brasília. Rev. Bras. de Geociências, 31(3),385-396.

SILVA, F. O., 1997. Geologia e petrologia do extremo noroeste do Complexo máfico-ultramáfico de Taquaral, GO. Tese de Doutorado, Universidade de Brasília, 171p.

SIMKIN, T., AND SMITH, J. V., 1970. Minor-element distribution in olivine. Journal of Geology, 78: 304-325.

SOTO, J. I., SOTO, V. M., 1995. PTMafic: software package for thermometry, barometry, and activity calculations in mafic rocks using an IBM-compatible computer. Computer \& Geosciences, 21, 619-652.

SUN, S. S., MACDONOUGH, W. F., 1989. Chemical and isotopic systematics of oceanic basalts: implications for mantle composition and processes. In: Saunders AD, Norry MJ (Eds.), Magmatism in the Ocean Basins. Geological Society Special Publications, pp. 313-345.

TEIXEIRA, A. S., FERREIRA FILHO, C. F., DELla GiUSTiNA, M. E. S., ARAúJO, S. M., AZEVEDO BARBOSA DA SILVA, H. H., 2015. Geology, Petrology and geochronology of the Lago Grande Layered Complex: evidence for a PGE-mineralized magmatic suite in the Carajás Mineral Province, Brazil. Journal of South American Earth Sciences, doi: 10.1016/j.jsames.2015.09.006

VAlERIANO, C. M., PIMENTEL, M. M., HEILBRON, M., ALMEIDA, J. C. H., TROUW, R. A. J., 2008. Tectonic evolution of the Brasília belt, Central Brazil, an early assembly of 
Gondwana. In: Pankhurst, R. J., Trouw, R. A. J., Brito Neves, B. B., de Wit, M. J. (Eds.) West Gondwana: Prec-cenozoic correlations across the South Atlantic region. Geological Society of London, Special Publications, 294: 197-210.

WELLS, P. R. A., 1980. Thermal models for magnetite accretion and subsequent metamorphism of continental crust. Earth and Planetary Science Letters, 46, 253-265.

WOOD, B. J., 1975. The influence of pressure, temperature and bulk composition on the appearence of garnet in ortho-gneisses - an example from South Harris, Scotland. Earth Planet. Sci. Lett., 26, 299-311. 


\begin{abstract}
ANEXOS
Resultados de química mineral (análises de microssonda) - olvina (ol), ortopiroxênio (opx), clinopiroxênio (cpx), plagioclásio (plg), granada (grt), biotita (bt), hialofana (hy), pirrotita (po), pentlandita (pn), pirita (py), calcopirita (calc), cromita (chr) e ilmenita (ilm) do Complexo MáficoUltamáfico de Damolândia.
\end{abstract}




\begin{tabular}{|ccl|}
\hline AMOSTRA & PROF. & \multicolumn{1}{c|}{ DESCRIÇÃO } \\
DM 04 & 276.45 & NORITO \\
DM 06A & 220.2 & XENÓLITO \\
DM 06B & 220.4 & ORTOPIROXENITO SULFETADO GROSSO \\
DM 09 & 209.35 & ORTOPIROXENITO COM XENÓLIT \\
DM 10 & 209.45 & OLIVINA ORTOPIROXENITO \\
DM 11 & 177.5 & HARZBURGITO \\
DM 13 & 149.6 & HARZBURGITO COM OIKOCRYSTS DE PIROXÊNIO \\
DM 14 & 102.4 & OLIVINA ORTOPIROXENITO \\
DM 16 & 68.25 & GABRONORITO TARDIO \\
DM 18 & 0 & GABRONORITO TARDIO \\
DM 20 & 0 & GRANULITO REGIONAL \\
DM 19 & 0 & GRANADA-HEDEMBERGITA GRANULITO \\
\hline
\end{tabular}

\section{OLIVINA}

\begin{tabular}{|c|c|c|c|c|c|c|c|c|c|c|c|c|c|}
\hline Sample & DM-11_c1_o & M-11_c1_o & M-11_c1_ol & -11_c1_ol & 11_c1_ol & 11_c1_ol 8 & 11_c1_ol D & 11_c1_ol D & 1_c3_ol D & I_c3_ol 2D & 1_c3_ol 3DI & 1_c3_ol & 4 \\
\hline Depth & $\mathrm{Hzb}$ & $\mathrm{Hzb}$ & $\mathrm{Hzb}$ & $\mathrm{Hzb}$ & $\mathrm{Hzb}$ & $\mathrm{Hzb}$ & $\mathrm{Hzb}$ & $\mathrm{Hzb}$ & $\mathrm{Hzb}$ & $\mathrm{Hzb}$ & $\mathrm{Hzb}$ & $\mathrm{Hzb}$ & \\
\hline Rock & 177.5 & 177.5 & 177.5 & 177.5 & 177.5 & 177.5 & 177.5 & 177.5 & 177.5 & 177.5 & 177.5 & 177.5 & \\
\hline $\mathrm{SiO}_{2}(\mathrm{wt} \%)$ & 39.252 & 39.444 & 39.149 & 39.717 & 39.302 & 39.783 & 40.138 & 41.639 & 39.475 & 39.45 & 39.06 & 39.63 & \\
\hline $\mathrm{Al}_{2} \mathrm{O}_{3}(\mathrm{wt} \%)$ & 0.008 & 0 & 0.01 & 0.013 & 0 & 0.011 & 0.03 & 0.092 & 0 & 0.003 & 0 & 0 & \\
\hline $\mathrm{FeO}(\mathrm{wt} \%)$ & 16.214 & 16.851 & 16.36 & 16.971 & 16.665 & 16.539 & 16.985 & 16.897 & 16.401 & 16.658 & 16.93 & 16.758 & \\
\hline $\mathrm{MnO}(\mathrm{wt} \%)$ & 0.236 & 0.253 & 0.287 & 0.199 & 0.297 & 0.124 & 0.086 & 0.1 & 0.26 & 0.113 & 0.328 & 0.333 & \\
\hline $\mathrm{MgO}$ (wt\%) & 44.547 & 44.2 & 44.427 & 44.111 & 44.719 & 44.484 & 40.665 & 41.502 & 44.719 & 44.791 & 44.175 & 44.33 & \\
\hline $\mathrm{CaO}$ (wt\%) & 0 & 0.01 & 0.027 & 0.06 & 0.003 & 0 & 0.051 & 0.162 & 0.022 & 0.025 & 0 & 0.021 & \\
\hline $\mathrm{Cr}_{2} \mathrm{O}_{3}(\mathrm{wt} \%)$ & 0.074 & 0.049 & 0 & 0.062 & 0.012 & 0 & 0 & 0.001 & 0 & 0.012 & 0.024 & 0 & \\
\hline $\mathrm{NiO}(w t \%)$ & 0.21 & 0.153 & 0.247 & 0.084 & 0.221 & 0.21 & 0.314 & 0.343 & 0.194 & 0.155 & 0.159 & 0.273 & \\
\hline Total & 100.541 & 100.96 & 100.507 & 101.217 & 101.219 & 101.151 & 98.269 & 100.736 & 101.071 & 101.207 & 100.676 & 101.345 & \\
\hline $\mathrm{Si}$ & 0.984 & 0.986 & 0.982 & 0.992 & 0.980 & 0.992 & 1.150 & 1.195 & 0.985 & 0.982 & 0.980 & 0.989 & \\
\hline $\mathrm{Al}$ & 0.000 & 0.000 & 0.000 & 0.000 & 0.000 & 0.000 & 0.001 & 0.003 & 0.000 & 0.000 & 0.000 & 0.000 & \\
\hline $\mathrm{Cr}$ & 0.001 & 0.001 & 0.000 & 0.001 & 0.000 & 0.000 & 0.000 & 0.000 & 0.000 & 0.000 & 0.000 & 0.000 & \\
\hline $\mathrm{Fe}^{+3}$ & 0.016 & 0.010 & 0.018 & 0.006 & 0.020 & 0.005 & 0.000 & 0.000 & 0.015 & 0.016 & 0.019 & 0.011 & \\
\hline $\mathrm{Mg}$ & 1.665 & 1.648 & 1.662 & 1.643 & 1.662 & 1.653 & 1.651 & 1.604 & 1.663 & 1.663 & 1.653 & 1.649 & \\
\hline $\mathrm{Fe}^{+2}$ & 0.310 & 0.333 & 0.309 & 0.344 & 0.307 & 0.334 & 0.191 & 0.189 & 0.312 & 0.315 & 0.318 & 0.327 & \\
\hline $\mathrm{Mn}$ & 0.005 & 0.005 & 0.006 & 0.004 & 0.006 & 0.003 & 0.002 & 0.002 & 0.005 & 0.002 & 0.007 & 0.007 & \\
\hline $\mathrm{Ca}$ & 0.000 & 0.000 & 0.001 & 0.002 & 0.000 & 0.000 & 0.002 & 0.005 & 0.001 & 0.001 & 0.000 & 0.001 & \\
\hline $\mathrm{Ni}$ & 0.004 & 0.003 & 0.005 & 0.002 & 0.004 & 0.004 & 0.003 & 0.001 & 0.004 & 0.003 & 0.003 & 0.005 & \\
\hline Fo (\%) & 83.044 & 82.381 & 82.879 & 82.249 & 82.710 & 82.743 & 89.618 & 89.435 & 82.937 & 82.739 & 82.305 & 82.504 & \\
\hline $\mathrm{Ni}(\mathrm{ppm})$ & 1650.18 & 1202.274 & 1940.926 & 660.072 & 1736.618 & 1650.18 & 2467.412 & 2695.294 & 1524.452 & 1217.99 & 1249.422 & 2145.234 & \\
\hline Sample & DM-11_c2_ & M-11_c2_- & M-11_c2_c & И-11_c2_o & U-11_c2_o & 1-11_c2_c & 1-11_c2_ol & -11_c2_ol & 11_c2_ol D & 4_c4_ol 1[ & 4_c4_ol 2D & 4_c4_ol & 3 \\
\hline Depth & $\mathrm{Hzb}$ & $\mathrm{Hzb}$ & $\mathrm{Hzb}$ & $\mathrm{Hzb}$ & $\mathrm{Hzb}$ & $\mathrm{Hzb}$ & $\mathrm{Hzb}$ & $\mathrm{Hzb}$ & $\overline{\mathrm{H}} \mathrm{zb}$ & $\mathrm{Nrt}$ & $\mathrm{Nrt}$ & $\mathrm{Nrt}$ & \\
\hline Rock & 177.5 & 177.5 & 177.5 & 177.5 & 177.5 & 177.5 & 177.5 & 177.5 & 177.5 & 276.45 & 276.45 & 276.45 & \\
\hline $\mathrm{SiO}_{2}(\mathrm{wt} \%)$ & 39.587 & 39.299 & 39.814 & 39.489 & 39.567 & 39.613 & 38.911 & 39.519 & 39.04 & 53.263 & 53.17 & 53.378 & \\
\hline $\mathrm{Al}_{2} \mathrm{O}_{3}(\mathrm{wt} \%)$ & 0 & 0.008 & 0 & 0 & 0.003 & 0 & 0 & 0 & 0.023 & 0 & 0 & 0 & \\
\hline $\mathrm{FeO}(\mathrm{wt} \%)$ & 17.035 & 17.473 & 17.295 & 17.507 & 17.713 & 17.498 & 17.428 & 17.165 & 17.579 & 17.636 & 17.294 & 17.77 & \\
\hline $\mathrm{MnO}(\mathrm{wt} \%)$ & 0.231 & 0.241 & 0.166 & 0.186 & 0.117 & 0.206 & 0.211 & 0.244 & 0.301 & 0.25 & 0.392 & 0.223 & \\
\hline $\mathrm{MgO}(\mathrm{wt} \%)$ & 43.603 & 44.279 & 44.069 & 44.344 & 44.442 & 43.847 & 44.36 & 44.3 & 43.984 & 28.824 & 28.478 & 27.4 & \\
\hline $\mathrm{CaO}$ (wt\%) & 0.008 & 0.003 & 0.029 & 0.03 & 0 & 0 & 0.021 & 0.044 & 0.01 & 0.389 & 0.871 & 0.351 & \\
\hline $\mathrm{Cr}_{2} \mathrm{O}_{3}(\mathrm{wt} \%)$ & 0 & 0 & 0.025 & 0.049 & 0 & 0.086 & 0 & 0 & 0 & 0.023 & 0.037 & 0.062 & \\
\hline $\mathrm{NiO}(w t \%)$ & 0.186 & 0.163 & 0.178 & 0.178 & 0.229 & 0.082 & 0.247 & 0.118 & 0.149 & 0.112 & 0.035 & 0.041 & \\
\hline Total & 100.65 & 101.466 & 101.576 & 101.783 & 102.071 & 101.332 & 101.178 & 101.39 & 101.086 & 100.497 & 100.277 & 99.225 & \\
\hline $\mathrm{Si}$ & 0.996 & 0.980 & 0.993 & 0.982 & 0.982 & 0.991 & 0.972 & 0.986 & 0.978 & 1.449 & 1.453 & 1.444 & \\
\hline $\mathrm{Al}$ & 0.000 & 0.000 & 0.000 & 0.000 & 0.000 & 0.000 & 0.000 & 0.000 & 0.001 & 0.080 & 0.078 & 0.072 & \\
\hline $\mathrm{Cr}$ & 0.000 & 0.000 & 0.000 & 0.001 & 0.000 & 0.002 & 0.000 & 0.000 & 0.000 & 0.000 & 0.001 & 0.001 & \\
\hline $\mathrm{Fe}+3$ & 0.004 & 0.020 & 0.007 & 0.018 & 0.018 & 0.009 & 0.027 & 0.014 & 0.022 & 0.000 & 0.000 & 0.000 & \\
\hline $\mathrm{Mg}$ & 1.636 & 1.647 & 1.638 & 1.644 & 1.644 & 1.635 & 1.652 & 1.647 & 1.643 & 1.047 & 1.038 & 1.064 & \\
\hline $\mathrm{Fe}^{+2}$ & 0.351 & 0.325 & 0.348 & 0.330 & 0.331 & 0.350 & 0.311 & 0.330 & 0.326 & 0.401 & 0.395 & 0.402 & \\
\hline $\mathrm{Mn}$ & 0.005 & 0.005 & 0.004 & 0.004 & 0.002 & 0.004 & 0.004 & 0.005 & 0.006 & 0.006 & 0.009 & 0.005 & \\
\hline $\mathrm{Ca}$ & 0.000 & 0.000 & 0.001 & 0.001 & 0.000 & 0.000 & 0.001 & 0.001 & 0.000 & 0.011 & 0.025 & 0.010 & \\
\hline $\mathrm{Ni}$ & 0.004 & 0.003 & 0.004 & 0.004 & 0.005 & 0.002 & 0.005 & 0.002 & 0.003 & 0.002 & 0.001 & 0.001 & \\
\hline Fo (\%) & 82.024 & 81.876 & 81.957 & 81.869 & 81.830 & 81.708 & 81.941 & 82.145 & 81.686 & 72.301 & 72.423 & 72.590 & \\
\hline $\mathrm{Ni}(\mathrm{ppm})$ & 1461.588 & 1280.854 & 1398.724 & 1398.724 & 1799.482 & 644.356 & 1940.926 & 927.244 & 1170.842 & 880.096 & 275.03 & 322.178 & \\
\hline
\end{tabular}




\begin{tabular}{|c|c|c|c|c|c|c|c|c|c|c|c|c|}
\hline Amostra & \multicolumn{3}{|c|}{ DM-04_c4_ol DM-04_c4_ol DM-04_c4_ol } & \multirow{3}{*}{$\begin{array}{c}\text { DM-04_c4_ol } \\
\text { Nrt } \\
276.45\end{array}$} & \multirow{3}{*}{$\begin{array}{c}\text { DM-04_c4_ol } \\
\text { Nrt } \\
276.45\end{array}$} & \multicolumn{2}{|c|}{ DM-13_c1_ol 1DM-13_c1_ol } & \multicolumn{5}{|c|}{ DM-13_c1_ol DM-13_c1_ol DM-13_c3_ol DM-13_c3_ol 2DM-13_c3_ol } \\
\hline Prof. & Nrt & $\mathrm{Nrt}$ & $\overline{N r t}$ & & & $\mathrm{Hzb}$ & $\mathrm{Hzb}$ & $\mathrm{Hz} \bar{b}$ & $\mathrm{~Hz} \bar{b}$ & $\mathrm{~Hz} b$ & $\bar{H} z b$ & $\bar{H} z b$ \\
\hline Rocha & 276.45 & 276.45 & 276.45 & & & 149.6 & 149.6 & 149.6 & 149.6 & 149.6 & 149.6 & 149.6 \\
\hline $\mathrm{SiO}_{2}(\mathrm{wt} \%)$ & 53.279 & 53.23 & 53.456 & 53.545 & 53.57 & 38.932 & 38.093 & 38.318 & 38.209 & 38.871 & 37.943 & 38.331 \\
\hline $\mathrm{Al}_{2} \mathrm{O}_{3}(\mathrm{wt} \%)$ & 0.03 & 0.011 & 0 & 0 & 0 & 0 & 0 & 0.019 & 0 & 0.011 & 0 & 0 \\
\hline $\mathrm{FeO}(\mathrm{wt} \%)$ & 18.037 & 17.804 & 17.648 & 18.991 & 18.84 & 16.555 & 16.446 & 16.679 & 16.666 & 16.409 & 16.884 & 16.507 \\
\hline $\mathrm{MnO}(\mathrm{wt} \%)$ & 0.211 & 0.417 & 0.225 & 0.42 & 0.381 & 0.225 & 0.161 & 0.124 & 0.283 & 0.314 & 0.213 & 0.079 \\
\hline $\mathrm{MgO}$ (wt\%) & 28.668 & 27.646 & 27.108 & 26.405 & 28.639 & 43.454 & 43.366 & 43.916 & 43.803 & 43.407 & 43.851 & 43.865 \\
\hline $\mathrm{CaO}(\mathrm{wt} \%)$ & 0.445 & 0.376 & 0.974 & 0.292 & 0.477 & 0.01 & 0 & 0.004 & 0.056 & 0.009 & 0.037 & 0.041 \\
\hline $\mathrm{Cr}_{2} \mathrm{O}_{3}(\mathrm{wt} \%)$ & 0.087 & 0.111 & 0.076 & 0 & 0.036 & 0 & 0 & 0.038 & 0 & 0.038 & 0 & 0 \\
\hline $\mathrm{NiO}(\mathrm{wt} \%)$ & 0 & 0.051 & 0.063 & 0 & 0.123 & 0.226 & 0.183 & 0.193 & 0.139 & 0.162 & 0.242 & 0.17 \\
\hline Total & 100.757 & 99.646 & 99.55 & 99.653 & 102.066 & 99.402 & 98.249 & 99.291 & 99.156 & 99.221 & 99.17 & 98.993 \\
\hline $\mathrm{Si}$ & 1.456 & 1.452 & 1.455 & 1.455 & 1.444 & 0.990 & 0.979 & 0.974 & 0.972 & 0.990 & 0.966 & 0.976 \\
\hline $\mathrm{Al}$ & 0.063 & 0.074 & 0.067 & 0.065 & 0.075 & 0.000 & 0.000 & 0.001 & 0.000 & 0.000 & 0.000 & 0.000 \\
\hline $\mathrm{Cr}$ & 0.002 & 0.002 & 0.002 & 0.000 & 0.001 & 0.000 & 0.000 & 0.001 & 0.000 & 0.001 & 0.000 & 0.000 \\
\hline $\mathrm{Fe}^{+3}$ & 0.000 & 0.000 & 0.000 & 0.000 & 0.000 & 0.010 & 0.021 & 0.026 & 0.027 & 0.010 & 0.034 & 0.023 \\
\hline $\mathrm{Mg}$ & 1.046 & 1.043 & 1.019 & 1.029 & 1.030 & 1.648 & 1.661 & 1.664 & 1.661 & 1.649 & 1.664 & 1.665 \\
\hline $\mathrm{Fe}^{+2}$ & 0.412 & 0.406 & 0.402 & 0.432 & 0.425 & 0.333 & 0.311 & 0.303 & 0.302 & 0.331 & 0.292 & 0.305 \\
\hline $\mathrm{Mn}$ & 0.005 & 0.010 & 0.005 & 0.010 & 0.009 & 0.005 & 0.004 & 0.003 & 0.006 & 0.007 & 0.005 & 0.002 \\
\hline $\mathrm{Ca}$ & 0.013 & 0.011 & 0.028 & 0.009 & 0.014 & 0.000 & 0.000 & 0.000 & 0.002 & 0.000 & 0.001 & 0.001 \\
\hline $\mathrm{Ni}$ & 0.000 & 0.001 & 0.001 & 0.000 & 0.003 & 0.005 & 0.004 & 0.004 & 0.003 & 0.003 & 0.005 & 0.003 \\
\hline Fo (\%) & 71.726 & 71.972 & 71.721 & 70.455 & 70.811 & 82.392 & 82.458 & 82.437 & 82.411 & 82.504 & 82.237 & 82.570 \\
\hline $\mathrm{Ni}(\mathrm{ppm})$ & 0 & 400.758 & 495.054 & 0 & 966.534 & 1775.908 & 1438.014 & 1516.594 & 1092.262 & 1272.996 & 1901.636 & 1335.86 \\
\hline Amostra & \multicolumn{3}{|c|}{ DM-13_c3_ol DM-13_c4_ol DM-13_c4_ol } & DM-13_c2_ol & \multicolumn{3}{|c|}{ DM-13 c2 ol DM-13 c2 ol DM-14 c3 ol } & DM-14_c3_ol & DM-14_c2_ol & M-14_c2_ol & M-14_c2_ol & 1-14_c1_ol \\
\hline Prof. & $\mathrm{Hzb}$ & $\mathrm{Hzb}$ & $\mathrm{Hzb}$ & $\mathrm{Hz} \bar{b}$ & $\mathrm{~Hz} \bar{b}$ & $\mathrm{~Hz} b$ & OIOpxt & OIŌpxt & OIŌpxt & OIŌpxt & OIOpxt & OIOpxt \\
\hline Rocha & 149.6 & 149.6 & 149.6 & 149.6 & 149.6 & 149.6 & 102.4 & 102.4 & 102.4 & 102.4 & 102.4 & 102.4 \\
\hline $\mathrm{SiO}_{2}(\mathrm{wt} \%)$ & 38.01 & 38.157 & 38.641 & 39.121 & 39.087 & 38.975 & 39.206 & 39.454 & 53.879 & 39.037 & 38.864 & 39.168 \\
\hline $\mathrm{Al}_{2} \mathrm{O}_{3}(\mathrm{wt} \%)$ & 0 & 0 & 0 & 0 & 0.024 & 0 & 0 & 0.023 & 3.394 & 0.006 & 0 & 0 \\
\hline $\mathrm{FeO}(\mathrm{wt} \%)$ & 16.835 & 16.536 & 16.334 & 16.68 & 16.499 & 16.546 & 15.766 & 15.838 & 10.774 & 16.11 & 15.585 & 15.79 \\
\hline $\mathrm{MnO}(\mathrm{wt} \%)$ & 0.297 & 0.227 & 0.207 & 0.167 & 0.204 & 0.151 & 0.144 & 0.254 & 0.3 & 0.248 & 0.194 & 0.228 \\
\hline $\mathrm{MgO}$ (wt\%) & 44.052 & 44.665 & 43.965 & 44.105 & 43.754 & 43.68 & 44.594 & 44.088 & 30.752 & 44.576 & 44.848 & 44.643 \\
\hline $\mathrm{CaO}(\mathrm{wt} \%)$ & 0.054 & 0.04 & 0.028 & 0.02 & 0.016 & 0.004 & 0.008 & 0.006 & 0.596 & 0.024 & 0.027 & 0.007 \\
\hline $\mathrm{Cr}_{2} \mathrm{O}_{3}(\mathrm{wt} \%)$ & 0 & 0.1 & 0.001 & 0 & 0.026 & 0 & 0.036 & 0.037 & 0.038 & 0 & 0.038 & 0.038 \\
\hline $\mathrm{NiO}(\mathrm{wt} \%)$ & 0.107 & 0.254 & 0.172 & 0.137 & 0.172 & 0.09 & 0.176 & 0.193 & 0.072 & 0.151 & 0.109 & 0.125 \\
\hline Total & 99.355 & 99.979 & 99.348 & 100.23 & 99.782 & 99.446 & 99.93 & 99.893 & 99.805 & 100.152 & 99.665 & 99.999 \\
\hline $\mathrm{Si}$ & 0.965 & 0.961 & 0.981 & 0.984 & 0.989 & 0.990 & 0.986 & 0.996 & 1.421 & 0.981 & 0.978 & 0.985 \\
\hline $\mathrm{Al}$ & 0.000 & 0.000 & 0.000 & 0.000 & 0.001 & 0.000 & 0.000 & 0.001 & 0.105 & 0.000 & 0.000 & 0.000 \\
\hline $\mathrm{Cr}$ & 0.000 & 0.002 & 0.000 & 0.000 & 0.001 & 0.000 & 0.001 & 0.001 & 0.001 & 0.000 & 0.001 & 0.001 \\
\hline $\mathrm{Fe}^{+3}$ & 0.035 & 0.038 & 0.019 & 0.012 & 0.010 & 0.010 & 0.011 & 0.004 & 0.000 & 0.019 & 0.019 & 0.014 \\
\hline $\mathrm{Mg}$ & 1.667 & 1.677 & 1.664 & 1.654 & 1.651 & 1.654 & 1.672 & 1.659 & 1.209 & 1.671 & 1.683 & 1.674 \\
\hline $\mathrm{Fe}^{+2}$ & 0.288 & 0.274 & 0.308 & 0.327 & 0.330 & 0.331 & 0.310 & 0.327 & 0.238 & 0.302 & 0.290 & 0.304 \\
\hline $\mathrm{Mn}$ & 0.006 & 0.005 & 0.004 & 0.004 & 0.004 & 0.003 & 0.003 & 0.005 & 0.007 & 0.005 & 0.004 & 0.005 \\
\hline $\mathrm{Ca}$ & 0.001 & 0.001 & 0.001 & 0.001 & 0.000 & 0.000 & 0.000 & 0.000 & 0.017 & 0.001 & 0.001 & 0.000 \\
\hline $\mathrm{Ni}$ & 0.002 & 0.005 & 0.004 & 0.003 & 0.004 & 0.002 & 0.004 & 0.004 & 0.002 & 0.003 & 0.002 & 0.003 \\
\hline Fo (\%) & 82.346 & 82.803 & 82.753 & 82.498 & 82.540 & 82.475 & 83.450 & 83.228 & 83.575 & 83.144 & 83.686 & 83.444 \\
\hline $\mathrm{Ni}(\mathrm{ppm})$ & 840.806 & 1995.932 & 1351.576 & 1076.546 & 1351.576 & 707.22 & 1383.008 & 1516.594 & 565.776 & 1186.558 & 856.522 & 982.25 \\
\hline Amostra & DM-14_c1_ol & M-14_c1_o & M-14_c1_o & & & & & & & & & \\
\hline Prof. & OlOpxt & OlOpxt & OlOpxt & & & & & & & & & \\
\hline Rocha & 102.4 & 102.4 & 102.4 & & & & & & & & & \\
\hline $\mathrm{SiO}_{2}(\mathrm{wt} \%)$ & 39.644 & 39.557 & 39.647 & & & & & & & & & \\
\hline $\mathrm{Al}_{2} \mathrm{O}_{3}(\mathrm{wt} \%)$ & 0.005 & 0 & 0 & & & & & & & & & \\
\hline $\mathrm{FeO}(\mathrm{wt} \%)$ & 15.827 & 15.537 & 15.397 & & & & & & & & & \\
\hline $\mathrm{MnO}(\mathrm{wt} \%)$ & 0.337 & 0.181 & 0.246 & & & & & & & & & \\
\hline $\mathrm{MgO}(\mathrm{wt} \%)$ & 44.493 & 45.176 & 44.427 & & & & & & & & & \\
\hline $\mathrm{CaO}(\mathrm{wt} \%)$ & 0.034 & 0 & 0 & & & & & & & & & \\
\hline $\mathrm{Cr}_{2} \mathrm{O}_{3}$ (wt\%) & 0.05 & 0 & 0.038 & & & & & & & & & \\
\hline $\mathrm{NiO}(\mathrm{wt} \%)$ & 0.207 & 0.129 & 0.103 & & & & & & & & & \\
\hline Total & 100.597 & 100.58 & 99.858 & & & & & & & & & \\
\hline $\mathrm{Si}$ & 0.993 & 0.987 & 0.999 & & & & & & & & & \\
\hline $\mathrm{Al}$ & 0.000 & 0.000 & 0.000 & & & & & & & & & \\
\hline $\mathrm{Cr}$ & 0.001 & 0.000 & 0.001 & & & & & & & & & \\
\hline $\mathrm{Fe}^{+3}$ & 0.007 & 0.012 & 0.001 & & & & & & & & & \\
\hline $\mathrm{Mg}$ & 1.662 & 1.681 & 1.669 & & & & & & & & & \\
\hline $\mathrm{Fe}^{+2}$ & 0.319 & 0.301 & 0.323 & & & & & & & & & \\
\hline $\mathrm{Mn}$ & 0.007 & 0.004 & 0.005 & & & & & & & & & \\
\hline $\mathrm{Ca}$ & 0.001 & 0.000 & 0.000 & & & & & & & & & \\
\hline $\mathrm{Ni}$ & 0.004 & 0.003 & 0.002 & & & & & & & & & \\
\hline Fo (\%) & 83.365 & 83.827 & 83.723 & & & & & & & & & \\
\hline $\mathrm{Ni}(\mathrm{ppm})$ & 1626.606 & 1013.682 & 809.374 & & & & & & & & & \\
\hline
\end{tabular}




\section{ORTOPIROXÊNIO}

\begin{tabular}{|c|c|c|c|c|c|c|c|c|c|c|c|c|}
\hline \multirow{3}{*}{$\begin{array}{l}\text { Amostra } \\
\text { Prof. } \\
\text { Rocha }\end{array}$} & \multicolumn{12}{|c|}{ M-13_c1_px DM-13_c1_px BM-13_c1_px 4px com sulfet甲x com sulfetopx com sulfetopx com sulfetopx com sulfeto 14_c3_px igne 4_c3_px igne04_c3_px igne04_c3_px igneo } \\
\hline & 149.6 & $1 \overline{4} 9 . \overline{6}$ & $149 . \overline{6}$ & 149.6 & 149.6 & 149.6 & 149.6 & 149.6 & 102.4 & 102.4 & 102.4 & 102.4 \\
\hline & $\mathrm{Hzb}$ & Hzb & $\mathrm{Hzb}$ & Hzb & Hzb & Hzb & $\mathrm{Hzb}$ & $\mathrm{Hzb}$ & OlOpxt & OlOpxt & OlOpxt & OlOpxt \\
\hline $\mathrm{SiO}_{2}(\mathrm{wt} \%)$ & 53.505 & 52.761 & 53.86 & 53.449 & 53.461 & 53.402 & 54.231 & 53.534 & 53.336 & 49.971 & 54.352 & 54.109 \\
\hline $\mathrm{TiO}_{2}(\mathrm{wt} \%)$ & 0.155 & 0.118 & 0.147 & 0.098 & 0.054 & 0.382 & 0 & 0 & 0.054 & 0.239 & 0.098 & 0.312 \\
\hline $\mathrm{Al}_{2} \mathrm{O}_{3}(\mathrm{wt} \%)$ & 3.159 & 3.176 & 3.484 & 3.197 & 3.259 & 3.71 & 2.649 & 3.479 & 3.997 & 7.253 & 2.842 & 3.589 \\
\hline $\mathrm{Cr}_{2} \mathrm{O}_{3}(\mathrm{wt} \%)$ & 0.189 & 0.205 & 0.215 & 0.204 & 0.126 & 0.381 & 0.063 & 0.152 & 0.178 & 0.492 & 0.19 & 0.101 \\
\hline $\mathrm{FeO}(\mathrm{wt} \%)$ & 10.986 & 10.66 & 10.698 & 10.956 & 11.216 & 10.102 & 10.871 & 11.107 & 10.83 & 11.35 & 10.523 & 10.401 \\
\hline $\mathrm{MnO}(\mathrm{wt} \%)$ & 0.303 & 0.215 & 0.102 & 0.259 & 0.217 & 0.263 & 0.278 & 0.243 & 0.21 & 0.227 & 0.138 & 0.205 \\
\hline $\mathrm{MgO}(\mathrm{wt} \%)$ & 30.88 & 30.667 & 30.503 & 30.305 & 30.632 & 29.098 & 31.143 & 30.716 & 30.04 & 29.234 & 31.265 & 31.009 \\
\hline $\mathrm{CaO}$ (wt\%) & 0.394 & 0.322 & 0.289 & 0.319 & 0.301 & 3.109 & 0.317 & 0.377 & 0.511 & 0.921 & 0.247 & 0.292 \\
\hline $\mathrm{NiO}(\mathrm{wt} \%)$ & 0.023 & 0.052 & 0.078 & 0.07 & 0.035 & 0.117 & 0.041 & 0.012 & 0.111 & 0.082 & 0.025 & 0.121 \\
\hline $\mathrm{BaO}$ (wt\%) & 0.019 & 0 & 0.015 & 0 & 0 & 0 & 0 & 0 & 0 & 0.027 & 0 & 0 \\
\hline Total & 99.613 & 98.176 & 99.391 & 98.857 & 99.301 & 100.564 & 99.593 & 99.62 & 99.267 & 99.796 & 99.68 & 100.139 \\
\hline $\mathrm{Si}$ & 1.887 & 1.886 & 1.905 & 1.903 & 1.893 & 1.877 & 1.911 & 1.888 & 1.891 & 1.763 & 1.912 & 1.897 \\
\hline $\mathrm{Ti}$ & 0.004 & 0.003 & 0.004 & 0.003 & 0.001 & 0.010 & 0.000 & 0.000 & 0.001 & 0.006 & 0.003 & 0.008 \\
\hline Al & 0.131 & 0.134 & 0.145 & 0.134 & 0.136 & 0.154 & 0.110 & 0.145 & 0.167 & 0.302 & 0.118 & 0.148 \\
\hline $\mathrm{Cr}$ & 0.005 & 0.006 & 0.006 & 0.006 & 0.004 & 0.011 & 0.002 & 0.004 & 0.005 & 0.014 & 0.005 & 0.003 \\
\hline $\mathrm{Fe}_{+3}$ & 0.080 & 0.083 & 0.032 & 0.049 & 0.073 & 0.063 & 0.066 & 0.076 & 0.046 & 0.148 & 0.048 & 0.038 \\
\hline $\mathrm{Fe}^{+2}$ & 0.244 & 0.236 & 0.285 & 0.277 & 0.259 & 0.234 & 0.255 & 0.252 & 0.275 & 0.187 & 0.262 & 0.267 \\
\hline $\mathrm{Mn}$ & 0.009 & 0.007 & 0.003 & 0.008 & 0.007 & 0.008 & 0.008 & 0.007 & 0.006 & 0.007 & 0.004 & 0.006 \\
\hline $\mathrm{Mg}$ & 1.624 & 1.634 & 1.608 & 1.608 & 1.617 & 1.525 & 1.636 & 1.615 & 1.587 & 1.537 & 1.639 & 1.621 \\
\hline $\mathrm{Ca}$ & 0.015 & 0.012 & 0.011 & 0.012 & 0.011 & 0.117 & 0.012 & 0.014 & 0.019 & 0.035 & 0.009 & 0.011 \\
\hline En (\%) & 82.730 & 83.157 & 83.087 & 82.619 & 82.476 & 78.644 & 83.116 & 82.530 & 82.340 & 80.616 & 83.718 & 83.687 \\
\hline Amostra & \multicolumn{12}{|c|}{ M-14_c2_px 14_c1_px reliqu4_c1_px reliqu4_c1_px reliqu4_c1_px reliquM-06B_c3_px M-06B_c3_px M-06B_c3_px M-06B_c3_px M-06B_c1_px M-06B_c1_px M-06B_c1_px } \\
\hline Prof. & $102 . \overline{4}$ & 102.4 & 102.4 & 102.4 & 102.4 & 220.4 & 220.4 & 220.4 & 220.4 & 220.4 & 220.4 & 220.4 \\
\hline Rocha & OlOpxt & OlOpxt & OlOpxt & OlOpxt & OlOpxt & Pxt & Pxt & Pxt & Pxt & Pxt & Pxt & Pxt \\
\hline $\mathrm{SiO}_{2}(\mathrm{wt} \%)$ & 53.333 & 53.134 & 53.482 & 52.819 & 53.448 & 52.227 & 51.941 & 52.377 & 52.511 & 52.197 & 52.718 & 52.266 \\
\hline $\mathrm{TiO}_{2}(\mathrm{wt} \%)$ & 0.112 & 0.352 & 0.254 & 0.236 & 0 & 0.268 & 0 & 0.321 & 0.486 & 0.064 & 0.053 & 0.155 \\
\hline $\mathrm{Al}_{2} \mathrm{O}_{3}(\mathrm{wt} \%)$ & 4.242 & 4.053 & 4.102 & 4.393 & 3.907 & 4.942 & 5.086 & 4.793 & 4.742 & 4.938 & 4.428 & 4.942 \\
\hline $\mathrm{Cr}_{2} \mathrm{O}_{3}(\mathrm{wt} \%)$ & 0.063 & 0.151 & 0.178 & 0.14 & 0.139 & 0.189 & 0.138 & 0.174 & 0.1 & 0.101 & 0.149 & 0.076 \\
\hline $\mathrm{FeO}(\mathrm{wt} \%)$ & 11.021 & 11.146 & 10.739 & 9.758 & 10.936 & 13.082 & 13.193 & 13.279 & 13.101 & 12.427 & 12.452 & 12.466 \\
\hline $\mathrm{MnO}(\mathrm{wt} \%)$ & 0.276 & 0.341 & 0.185 & 0.184 & 0.234 & 0.325 & 0.166 & 0.28 & 0.224 & 0.201 & 0.307 & 0.247 \\
\hline $\mathrm{MgO}(\mathrm{wt} \%)$ & 30.143 & 29.889 & 29.752 & 28.578 & 30.178 & 28.014 & 28.325 & 28.227 & 27.761 & 27.559 & 27.751 & 26.902 \\
\hline $\mathrm{CaO}$ (wt\%) & 0.327 & 0.483 & 1.354 & 3.986 & 0.457 & 0.702 & 0.287 & 0.344 & 1.158 & 1.919 & 2.199 & 2.532 \\
\hline $\mathrm{NiO}(\mathrm{wt} \%)$ & 0.047 & 0.037 & 0.123 & 0.041 & 0.078 & 0.09 & 0.099 & 0.1 & 0.057 & 0.027 & 0.115 & 0.08 \\
\hline $\mathrm{BaO}(\mathrm{wt} \%)$ & 0.017 & 0 & 0.067 & 0 & 0.002 & 0.046 & 0.076 & 0 & 0.048 & 0.118 & 0.046 & 0 \\
\hline Total & 99.581 & 99.586 & 100.236 & 100.135 & 99.379 & 99.885 & 99.311 & 99.895 & 100.188 & 99.551 & 100.218 & 99.666 \\
\hline $\mathrm{Si}$ & 1.885 & 1.881 & 1.883 & 1.862 & 1.892 & 1.863 & 1.859 & 1.867 & 1.870 & 1.864 & 1.875 & 1.871 \\
\hline $\mathrm{Ti}$ & 0.003 & 0.009 & 0.007 & 0.006 & 0.000 & 0.007 & 0.000 & 0.009 & 0.013 & 0.002 & 0.001 & 0.004 \\
\hline Al & 0.177 & 0.169 & 0.170 & 0.182 & 0.163 & 0.208 & 0.215 & 0.201 & 0.199 & 0.208 & 0.186 & 0.208 \\
\hline $\mathrm{Cr}$ & 0.002 & 0.004 & 0.005 & 0.004 & 0.004 & 0.005 & 0.004 & 0.005 & 0.003 & 0.003 & 0.004 & 0.002 \\
\hline $\mathrm{Fe}+3$ & 0.047 & 0.047 & 0.046 & 0.079 & 0.049 & 0.048 & 0.063 & 0.042 & 0.034 & 0.063 & 0.058 & 0.041 \\
\hline $\mathrm{Fe}^{+2}$ & 0.279 & 0.282 & 0.270 & 0.209 & 0.275 & 0.342 & 0.332 & 0.354 & 0.356 & 0.308 & 0.312 & 0.332 \\
\hline $\mathrm{Mn}$ & 0.008 & 0.010 & 0.006 & 0.005 & 0.007 & 0.010 & 0.005 & 0.008 & 0.007 & 0.006 & 0.009 & 0.007 \\
\hline $\mathrm{Mg}$ & 1.588 & 1.577 & 1.562 & 1.502 & 1.593 & 1.489 & 1.511 & 1.500 & 1.473 & 1.467 & 1.471 & 1.435 \\
\hline $\mathrm{Ca}$ & 0.012 & 0.018 & 0.051 & 0.151 & 0.017 & 0.027 & 0.011 & 0.013 & 0.044 & 0.073 & 0.084 & 0.097 \\
\hline En (\%) & 82.447 & 81.913 & 80.959 & 77.412 & 82.361 & 78.126 & 78.829 & 78.575 & 77.237 & 76.746 & 76.414 & 75.324 \\
\hline Amostra & \multicolumn{12}{|c|}{ M-06B_c1_px M-06B_c1_px M-06B_c4_px M-06B_c4_px M-06B_c2_px M-06B_c2_px M-06B_c2_px M-06B_c2_px M-06B_c5_px M-06B_c5_px M-06B_c5_px c4_px recristal } \\
\hline Prof. & 220.4 & 220.4 & 220.4 & 220.4 & 220.4 & 220.4 & 220.4 & 220.4 & 220.4 & 220.4 & 220.4 & 220.2 \\
\hline Rocha & Pxt & Pxt & Pxt & Pxt & Pxt & Pxt & Pxt & Pxt & Pxt & Pxt & Pxt & Xnt \\
\hline $\mathrm{SiO}_{2}(\mathrm{wt} \%)$ & 53.038 & 51.871 & 51.9 & 52.335 & 52.806 & 52.76 & 53.108 & 52.663 & 52.685 & 52.282 & 51.95 & 52.168 \\
\hline $\mathrm{TiO}_{2}(\mathrm{wt} \%)$ & 0.053 & 0.535 & 0.494 & 0.214 & 0 & 0.19 & 0.102 & 0.038 & 0.165 & 0.344 & 0.327 & 0.134 \\
\hline $\mathrm{Al}_{2} \mathrm{O}_{3}(\mathrm{wt} \%)$ & 4.349 & 5.099 & 5.034 & 4.803 & 4.536 & 4.243 & 4.392 & 4.775 & 4.931 & 5.157 & 4.856 & 2.23 \\
\hline $\mathrm{Cr}_{2} \mathrm{O}_{3}(\mathrm{wt} \%)$ & 0.114 & 0.063 & 0.253 & 0.187 & 0.153 & 0.237 & 0.127 & 0.14 & 0.137 & 0.212 & 0.114 & 0.182 \\
\hline $\mathrm{FeO}(\mathrm{wt} \%)$ & 13.086 & 13.032 & 11.601 & 12.876 & 12.751 & 12.346 & 12.464 & 12.573 & 13.575 & 13.991 & 13.515 & 19.24 \\
\hline $\mathrm{MnO}(\mathrm{wt} \%)$ & 0.233 & 0.111 & 0.2 & 0.289 & 0.425 & 0.324 & 0.277 & 0.12 & 0.414 & 0.22 & 0.264 & 0.324 \\
\hline $\mathrm{MgO}$ (wt\%) & 28.73 & 28.447 & 26.342 & 28.757 & 28.6 & 28.374 & 28.296 & 28.62 & 28.031 & 27.933 & 27.764 & 24.634 \\
\hline $\mathrm{CaO}$ (wt\%) & 0.339 & 0.444 & 3.901 & 0.337 & 0.417 & 1.424 & 1.032 & 0.411 & 0.461 & 0.312 & 0.35 & 0.554 \\
\hline $\mathrm{NiO}(\mathrm{wt} \%)$ & 0.059 & 0 & 0 & 0.037 & 0.086 & 0.072 & 0.037 & 0.014 & 0.068 & 0.029 & 0.045 & 0.064 \\
\hline $\mathrm{BaO}$ (wt\%) & 0.036 & 0.021 & 0 & 0.084 & 0 & 0.031 & 0 & 0.114 & 0 & 0.063 & 0 & 0 \\
\hline Total & 100.037 & 99.623 & 99.725 & 99.919 & 99.774 & 100.001 & 99.835 & 99.468 & 100.467 & 100.543 & 99.185 & 99.53 \\
\hline $\mathrm{Si}$ & 1.883 & 1.848 & 1.856 & 1.859 & 1.879 & 1.875 & 1.889 & 1.878 & 1.869 & 1.856 & 1.866 & 1.918 \\
\hline $\mathrm{Ti}$ & 0.001 & 0.014 & 0.013 & 0.006 & 0.000 & 0.005 & 0.003 & 0.001 & 0.004 & 0.009 & 0.009 & 0.004 \\
\hline $\mathrm{Al}$ & 0.182 & 0.214 & 0.212 & 0.201 & 0.190 & 0.178 & 0.184 & 0.201 & 0.206 & 0.216 & 0.206 & 0.097 \\
\hline $\mathrm{Cr}$ & 0.003 & 0.002 & 0.007 & 0.005 & 0.004 & 0.007 & 0.004 & 0.004 & 0.004 & 0.006 & 0.003 & 0.005 \\
\hline $\mathrm{Fe}+3$ & 0.047 & 0.061 & 0.048 & 0.065 & 0.050 & 0.057 & 0.030 & 0.037 & 0.045 & 0.047 & 0.043 & 0.056 \\
\hline $\mathrm{Fe}^{+2}$ & 0.341 & 0.327 & 0.299 & 0.317 & 0.329 & 0.310 & 0.341 & 0.338 & 0.358 & 0.369 & 0.363 & 0.536 \\
\hline $\mathrm{Mn}$ & 0.007 & 0.003 & 0.006 & 0.009 & 0.013 & 0.010 & 0.008 & 0.004 & 0.012 & 0.007 & 0.008 & 0.010 \\
\hline $\mathrm{Mg}$ & 1.521 & 1.511 & 1.404 & 1.523 & 1.517 & 1.503 & 1.501 & 1.522 & 1.482 & 1.479 & 1.487 & 1.350 \\
\hline $\mathrm{Ca}$ & 0.013 & 0.017 & 0.149 & 0.013 & 0.016 & 0.054 & 0.039 & 0.016 & 0.018 & 0.012 & 0.013 & 0.022 \\
\hline En (\%) & 79.114 & 78.851 & 73.883 & 79.390 & 79.328 & 78.115 & 78.535 & 79.569 & 77.912 & 77.579 & 77.995 & 68.761 \\
\hline
\end{tabular}




\begin{tabular}{|c|c|c|c|c|c|c|c|c|c|c|c|c|}
\hline \multirow{3}{*}{$\begin{array}{l}\text { Amostra } \\
\text { Prof. } \\
\text { Rocha }\end{array}$} & \multicolumn{12}{|c|}{ c4_px recristalc4_px recristalc4_px recristalc4_px recristalc4_px recristal 06_c1_px igne-06_c1_pxignec1_px recristalc1_px recristalc1_px recristalc1_px recristalc1_px recristal } \\
\hline & 220.2 & 220.2 & 220.2 & 220.2 & 220.2 & 220.2 & 220.2 & 220.2 & 220.2 & 220.2 & 220.2 & 220.2 \\
\hline & Xnt & Xnt & Xnt & Xnt & Xnt & Xnt & Xnt & Xnt & Xnt & Xnt & Xnt & Xnt \\
\hline $\mathrm{SiO}_{2}(\mathrm{wt} \%)$ & 52.454 & 52.753 & 52.539 & 52.719 & 52.626 & 52.355 & 52.93 & 52.658 & 52.541 & 52.39 & 52.246 & 52.821 \\
\hline $\mathrm{TiO}_{2}$ (wt\%) & 0.119 & 0 & 0.372 & 0.068 & 0.342 & 0.107 & 0.265 & 0.294 & 0.375 & 0.307 & 0.249 & 0 \\
\hline $\mathrm{Al}_{2} \mathrm{O}_{3}(\mathrm{wt} \%)$ & 2.059 & 2.171 & 2.581 & 2.067 & 2.128 & 2.048 & 1.972 & 1.862 & 2.113 & 2.101 & 1.994 & 1.327 \\
\hline $\mathrm{Cr}_{2} \mathrm{O}_{3}(\mathrm{wt} \%)$ & 0.111 & 0.075 & 0.233 & 0.011 & 0.123 & 0.136 & 0.136 & 0.098 & 0.062 & 0.015 & 0.11 & 0.049 \\
\hline $\mathrm{FeO}(\mathrm{wt} \%)$ & 19.066 & 18.652 & 19.019 & 18.963 & 18.619 & 19.271 & 19.071 & 19.595 & 20.011 & 20.116 & 20.459 & 20.114 \\
\hline $\mathrm{MnO}(\mathrm{wt} \%)$ & 0.423 & 0.447 & 0.403 & 0.452 & 0.47 & 0.433 & 0.352 & 0.439 & 0.523 & 0.386 & 0.265 & 0.348 \\
\hline $\mathrm{MgO}$ (wt\%) & 24.99 & 24.587 & 24.49 & 24.873 & 24.931 & 24.456 & 24.651 & 24.402 & 23.62 & 23.835 & 23.718 & 24.064 \\
\hline $\mathrm{CaO}(\mathrm{wt} \%)$ & 0.433 & 0.52 & 0.555 & 0.443 & 0.546 & 0.411 & 0.436 & 0.741 & 0.642 & 0.691 & 0.653 & 0.429 \\
\hline $\mathrm{NiO}$ (wt\%) & 0.045 & 0.025 & 0.088 & 0.02 & 0 & 0.031 & 0.063 & 0.027 & 0.006 & 0.061 & 0.09 & 0.041 \\
\hline $\mathrm{BaO}$ (wt\%) & 0 & 0 & 0 & 0 & 0 & 0.053 & 0.041 & 0 & 0.039 & 0.101 & 0.069 & 0 \\
\hline Total & 99.7 & 99.23 & 100.28 & 99.616 & 99.785 & 99.301 & 99.917 & 100.116 & 99.932 & 100.003 & 99.853 & 99.193 \\
\hline $\mathrm{Si}$ & 1.922 & 1.943 & 1.920 & 1.934 & 1.927 & 1.933 & 1.941 & 1.931 & 1.938 & 1.930 & 1.930 & 1.958 \\
\hline $\mathrm{Ti}$ & 0.003 & 0.000 & 0.010 & 0.002 & 0.009 & 0.003 & 0.007 & 0.008 & 0.010 & 0.009 & 0.007 & 0.000 \\
\hline $\mathrm{Al}$ & 0.089 & 0.094 & 0.111 & 0.089 & 0.092 & 0.089 & 0.085 & 0.080 & 0.092 & 0.091 & 0.087 & 0.058 \\
\hline $\mathrm{Cr}$ & 0.003 & 0.002 & 0.007 & 0.000 & 0.004 & 0.004 & 0.004 & 0.003 & 0.002 & 0.000 & 0.003 & 0.001 \\
\hline $\mathrm{Fe}^{+3}$ & 0.060 & 0.017 & 0.023 & 0.039 & 0.032 & 0.035 & 0.016 & 0.039 & 0.011 & 0.032 & 0.035 & 0.027 \\
\hline $\mathrm{Fe}^{+2}$ & 0.525 & 0.557 & 0.559 & 0.542 & 0.538 & 0.560 & 0.569 & 0.562 & 0.607 & 0.588 & 0.597 & 0.596 \\
\hline $\mathrm{Mn}$ & 0.013 & 0.014 & 0.012 & 0.014 & 0.015 & 0.014 & 0.011 & 0.014 & 0.016 & 0.012 & 0.008 & 0.011 \\
\hline $\mathrm{Mg}$ & 1.365 & 1.350 & 1.334 & 1.360 & 1.361 & 1.346 & 1.348 & 1.334 & 1.299 & 1.309 & 1.306 & 1.330 \\
\hline $\mathrm{Ca}$ & 0.017 & 0.021 & 0.022 & 0.017 & 0.021 & 0.016 & 0.017 & 0.029 & 0.025 & 0.027 & 0.026 & 0.017 \\
\hline En (\%) & 69.423 & 69.407 & 68.873 & 69.421 & 69.701 & 68.770 & 69.122 & 67.921 & 66.899 & 66.922 & 66.503 & 67.490 \\
\hline Amostra & px recris & px recris & px recris & px recrist & px recrist & px recrist & px recrista & 06_c2_px & 1_c3_px 1 & 1_c3_px 1 & 1_c1_px 1 & 11_c1_px 2 \\
\hline Prof. & 220.2 & 220.2 & 220.2 & 220.2 & 220.2 & 220.2 & 220.2 & 220.2 & 177.5 & 177.5 & 177.5 & 177.5 \\
\hline Rocha & Xnt & Xnt & Xnt & Xnt & Xnt & Xnt & Xnt & Xnt & $\mathrm{Hzb}$ & $\mathrm{Hzb}$ & $\mathrm{Hzb}$ & $\mathrm{Hzb}$ \\
\hline $\mathrm{SiO}_{2}(\mathrm{wt} \%)$ & 52.985 & 52.306 & 52.677 & 52.138 & 52.968 & 52.907 & 52.943 & 36.331 & 53.328 & 53.729 & 52.475 & 53.848 \\
\hline $\mathrm{TiO}_{2}$ (wt\%) & 0 & 0.289 & 0.039 & 0.095 & 0.264 & 0.034 & 0.473 & 0.105 & 0.259 & 0 & 0.127 & 0.103 \\
\hline $\mathrm{Al}_{2} \mathrm{O}_{3}(\mathrm{wt} \%)$ & 1.41 & 2.065 & 2.081 & 2.214 & 1.297 & 1.715 & 1.657 & 12.25 & 4.548 & 3.741 & 4.392 & 3.747 \\
\hline $\mathrm{Cr}_{2} \mathrm{O}_{3}(\mathrm{wt} \%)$ & 0.134 & 0.074 & 0.221 & 0.147 & 0.073 & 0.048 & 0.121 & 0 & 0.124 & 0.177 & 0.176 & 0.226 \\
\hline $\mathrm{FeO}$ (wt\%) & 19.962 & 19.012 & 18.662 & 19.485 & 19.976 & 20.196 & 19.71 & 15.262 & 11.568 & 11.62 & 11.12 & 11.219 \\
\hline $\mathrm{MnO}(\mathrm{wt} \%)$ & 0.538 & 0.427 & 0.434 & 0.552 & 0.476 & 0.525 & 0.302 & 0.112 & 0.147 & 0.261 & 0.155 & 0.08 \\
\hline $\mathrm{MgO}(\mathrm{wt} \%)$ & 24.327 & 24.419 & 23.971 & 24.413 & 24.506 & 23.68 & 23.722 & 23.686 & 30.171 & 30.862 & 29.683 & 30.514 \\
\hline $\mathrm{CaO}(\mathrm{wt} \%)$ & 0.423 & 1.014 & 1.22 & 0.646 & 0.52 & 0.536 & 0.644 & 0.186 & 0.34 & 0.387 & 1.554 & 0.481 \\
\hline $\mathrm{NiO}$ (wt\%) & 0.023 & 0.1 & 0.072 & 0 & 0.035 & 0.112 & 0.035 & 0 & 0.002 & 0 & 0 & 0.078 \\
\hline $\mathrm{BaO}(\mathrm{wt} \%)$ & 0 & 0.083 & 0.007 & 0 & 0.022 & 0.017 & 0 & 0.008 & 0.04 & 0 & 0.103 & 0 \\
\hline Total & 99.802 & 99.789 & 99.384 & 99.69 & 100.137 & 99.77 & 99.607 & 87.94 & 100.527 & 100.777 & 99.785 & 100.296 \\
\hline $\mathrm{Si}$ & 1.951 & 1.923 & 1.944 & 1.917 & 1.944 & 1.956 & 1.958 & 1.463 & 1.869 & 1.874 & 1.853 & 1.890 \\
\hline $\mathrm{Ti}$ & 0.000 & 0.008 & 0.001 & 0.003 & 0.007 & 0.001 & 0.013 & 0.003 & 0.007 & 0.000 & 0.003 & 0.003 \\
\hline $\mathrm{Al}$ & 0.061 & 0.089 & 0.091 & 0.096 & 0.056 & 0.075 & 0.072 & 0.581 & 0.188 & 0.154 & 0.183 & 0.155 \\
\hline $\mathrm{Cr}$ & 0.004 & 0.002 & 0.006 & 0.004 & 0.002 & 0.001 & 0.004 & 0.000 & 0.003 & 0.005 & 0.005 & 0.006 \\
\hline $\mathrm{Fe}+3$ & 0.033 & 0.049 & 0.013 & 0.060 & 0.042 & 0.010 & 0.000 & 0.491 & 0.058 & 0.093 & 0.101 & 0.054 \\
\hline $\mathrm{Fe}^{+2}$ & 0.582 & 0.536 & 0.563 & 0.539 & 0.571 & 0.614 & 0.610 & 0.023 & 0.281 & 0.246 & 0.228 & 0.276 \\
\hline $\mathrm{Mn}$ & 0.017 & 0.013 & 0.014 & 0.017 & 0.015 & 0.016 & 0.009 & 0.004 & 0.004 & 0.008 & 0.005 & 0.002 \\
\hline $\mathrm{Mg}$ & 1.335 & 1.338 & 1.319 & 1.338 & 1.340 & 1.305 & 1.308 & 1.422 & 1.576 & 1.605 & 1.563 & 1.596 \\
\hline $\mathrm{Ca}$ & 0.017 & 0.040 & 0.048 & 0.025 & 0.020 & 0.021 & 0.026 & 0.008 & 0.013 & 0.014 & 0.059 & 0.018 \\
\hline En (\%) & 67.897 & 68.185 & 67.874 & 68.178 & 67.910 & 66.903 & 67.312 & 73.147 & 81.754 & 81.952 & 80.142 & 82.130 \\
\hline Amostra & DM-11_c1_px & M-11_c1_F & M-11_c1_ト & M-11_c3_p & 1-11_c3_p & 1-11_c3_p & 1-11_c3_px & 1-11_c3_px & 11_c2_px & 11_c2_px & 11_c2_px & 11_c2_px 1 . \\
\hline Prof. & 177.5 & 177.5 & 177.5 & 177.5 & 177.5 & 177.5 & 177.5 & 177.5 & 177.5 & 177.5 & 177.5 & 177.5 \\
\hline Rocha & $\mathrm{Hzb}$ & $\mathrm{Hzb}$ & $\mathrm{Hzb}$ & $\mathrm{Hzb}$ & $\mathrm{Hzb}$ & $\mathrm{Hzb}$ & $\mathrm{Hzb}$ & $\mathrm{Hzb}$ & $\mathrm{Hzb}$ & $\mathrm{Hzb}$ & $\mathrm{Hzb}$ & $\mathrm{Hzb}$ \\
\hline $\mathrm{SiO}_{2}$ (wt\%) & 54.806 & 54.806 & 39.316 & 53.408 & 53.432 & 54.482 & 54.21 & 54.645 & 53.456 & 53.575 & 53.821 & 53.651 \\
\hline $\mathrm{TiO}_{2}(\mathrm{wt} \%)$ & 0.039 & 0.039 & 0.014 & 0.318 & 0.004 & 0.287 & 0.165 & 0.084 & 0.189 & 0.209 & 0.17 & 0 \\
\hline $\mathrm{Al}_{2} \mathrm{O}_{3}$ (wt\%) & 2.658 & 2.658 & 0.002 & 4.03 & 3.799 & 3.444 & 3.058 & 2.892 & 5.033 & 4.742 & 4.472 & 4.62 \\
\hline $\mathrm{Cr}_{2} \mathrm{O}_{3}(\mathrm{wt} \%)$ & 0.1 & 0.1 & 0 & 0.087 & 0.15 & 0.202 & 0.199 & 0.114 & 0.176 & 0.077 & 0.05 & 0.137 \\
\hline $\mathrm{FeO}(\mathrm{wt} \%)$ & 11.22 & 11.22 & 16.471 & 11.133 & 11.394 & 11.082 & 11.075 & 11.293 & 11.251 & 11.559 & 11.475 & 11.45 \\
\hline $\mathrm{MnO}(\mathrm{wt} \%)$ & 0.214 & 0.214 & 0.198 & 0.237 & 0.267 & 0.31 & 0.178 & 0.331 & 0.328 & 0.257 & 0.308 & 0.329 \\
\hline $\mathrm{MgO}(\mathrm{wt} \%)$ & 31.099 & 31.099 & 44.949 & 30.562 & 30.025 & 30.922 & 31.157 & 31.219 & 29.458 & 30.427 & 30.358 & 30.339 \\
\hline $\mathrm{CaO}$ (wt\%) & 0.217 & 0.217 & 0.023 & 0.331 & 0.42 & 0.347 & 0.489 & 0.381 & 1.32 & 0.374 & 0.446 & 0.324 \\
\hline $\mathrm{NiO}$ (wt\%) & 0.049 & 0.049 & 0.247 & 0.119 & 0 & 0.039 & 0.035 & 0.002 & 0.09 & 0.041 & 0.065 & 0.08 \\
\hline $\mathrm{BaO}$ (wt\%) & 0 & 0 & 0 & 0.004 & 0 & 0 & 0 & 0 & 0.093 & 0.057 & 0.047 & 0 \\
\hline Total & 100.402 & 100.402 & 101.22 & 100.229 & 99.491 & 101.115 & 100.566 & 100.961 & 101.394 & 101.318 & 101.212 & 100.93 \\
\hline $\mathrm{Si}$ & 1.920 & 1.920 & 1.307 & 1.875 & 1.891 & 1.895 & 1.894 & 1.903 & 1.864 & 1.863 & 1.874 & 1.872 \\
\hline $\mathrm{Ti}$ & 0.001 & 0.001 & 0.000 & 0.008 & 0.000 & 0.008 & 0.004 & 0.002 & 0.005 & 0.005 & 0.004 & 0.000 \\
\hline $\mathrm{Al}$ & 0.110 & 0.110 & 0.000 & 0.167 & 0.158 & 0.141 & 0.126 & 0.119 & 0.207 & 0.194 & 0.184 & 0.190 \\
\hline $\mathrm{Cr}$ & 0.003 & 0.003 & 0.000 & 0.002 & 0.004 & 0.006 & 0.005 & 0.003 & 0.005 & 0.002 & 0.001 & 0.004 \\
\hline $\mathrm{Fe}+3$ & 0.046 & 0.046 & 1.385 & 0.066 & 0.057 & 0.050 & 0.072 & 0.068 & 0.052 & 0.067 & 0.057 & 0.062 \\
\hline $\mathrm{Fe}^{+2}$ & 0.282 & 0.282 & -0.927 & 0.261 & 0.281 & 0.272 & 0.252 & 0.260 & 0.276 & 0.270 & 0.277 & 0.272 \\
\hline $\mathrm{Mn}$ & 0.006 & 0.006 & 0.006 & 0.007 & 0.008 & 0.009 & 0.005 & 0.010 & 0.010 & 0.008 & 0.009 & 0.010 \\
\hline $\mathrm{Mg}$ & 1.624 & 1.624 & 2.228 & 1.599 & 1.584 & 1.604 & 1.623 & 1.620 & 1.531 & 1.577 & 1.576 & 1.578 \\
\hline $\mathrm{Ca}$ & 0.008 & 0.008 & 0.001 & 0.012 & 0.016 & 0.013 & 0.018 & 0.014 & 0.049 & 0.014 & 0.017 & 0.012 \\
\hline En (\%) & 82.822 & 82.822 & 82.923 & 82.499 & 81.770 & 82.705 & 82.598 & 82.529 & 80.227 & 81.837 & 81.793 & 82.008 \\
\hline
\end{tabular}




\begin{tabular}{|c|c|c|c|c|c|c|c|c|c|c|c|c|}
\hline \multirow{3}{*}{$\begin{array}{l}\text { Amostra } \\
\text { Prof. } \\
\text { Rocha }\end{array}$} & \multicolumn{12}{|c|}{ M-11_c2_px 1DM-11_c2_px 11_px com incl1_px com inclul_px com inclul_px com inclDMM-04_c4_px 1 M-04_c4_px 2 M-04_c3_px DM-04_c3_px 2 M-04_c3_px BM-04_c3_px } \\
\hline & $\overline{177.5}$ & 177.5 & 276.45 & 276.45 & 276.45 & 276.45 & 276.45 & $27 \overline{6} .4 \overline{5}$ & $276.4 \overline{5}$ & 276.45 & $27 \overline{6} .4 \overline{5}$ & $276.4 \overline{5}$ \\
\hline & $\mathrm{Hzb}$ & $\mathrm{Hzb}$ & Nrt & Nrt & $\mathrm{Nrt}$ & Nrt & $\mathrm{Nrt}$ & Nrt & $\mathrm{Nrt}$ & $\mathrm{Nrt}$ & Nrt & $\mathrm{Nrt}$ \\
\hline $\mathrm{SiO}_{2}(\mathrm{wt} \%)$ & 53.688 & 52.904 & 53.267 & 53.734 & 53.755 & 53.257 & 53.259 & 53.933 & 53.511 & 52.856 & 53.661 & 53.863 \\
\hline $\mathrm{TiO}_{2}(\mathrm{wt} \%)$ & 0.127 & 0.36 & 0.005 & 0.188 & 0 & 0.004 & 0 & 0.202 & 0.27 & 0.073 & 0 & 0 \\
\hline $\mathrm{Al}_{2} \mathrm{O}_{3}(\mathrm{wt} \%)$ & 4.964 & 5.275 & 2.484 & 2.202 & 2.031 & 2.144 & 2.65 & 1.909 & 2.312 & 2.139 & 2.279 & 2.146 \\
\hline $\mathrm{Cr}_{2} \mathrm{O}_{3}(\mathrm{wt} \%)$ & 0.113 & 0 & 0.21 & 0.185 & 0.085 & 0.148 & 0.184 & 0.123 & 0.111 & 0.049 & 0.147 & 0 \\
\hline $\mathrm{FeO}(\mathrm{wt} \%)$ & 11.224 & 11.29 & 17.93 & 17.956 & 18.611 & 18 & 18.094 & 17.602 & 17.379 & 18.609 & 18.077 & 17.988 \\
\hline $\mathrm{MnO}(\mathrm{wt} \%)$ & 0.235 & 0.126 & 0.487 & 0.389 & 0.324 & 0.295 & 0.361 & 0.304 & 0.42 & 0.377 & 0.348 & 0.381 \\
\hline $\mathrm{MgO}(\mathrm{wt} \%)$ & 30.414 & 28.911 & 25.772 & 25.769 & 25.787 & 25.754 & 26.063 & 26.617 & 26.083 & 25.434 & 26.278 & 25.854 \\
\hline $\mathrm{CaO}(\mathrm{wt} \%)$ & 0.659 & 1.908 & 0.348 & 0.37 & 0.389 & 0.386 & 0.346 & 0.255 & 0.38 & 0.489 & 0.392 & 0.369 \\
\hline $\mathrm{NiO}$ (wt\%) & 0.068 & 0.004 & 0.02 & 0.01 & 0 & 0.02 & 0.039 & 0 & 0 & 0.029 & 0 & 0.045 \\
\hline $\mathrm{BaO}(\mathrm{wt} \%)$ & 0 & 0 & 0.039 & 0 & 0.194 & 0 & 0.056 & 0.045 & 0.115 & 0 & 0 & 0.036 \\
\hline Total & 101.492 & 100.778 & 100.562 & 100.803 & 101.176 & 100.008 & 101.052 & 100.99 & 100.581 & 100.055 & 101.182 & 100.682 \\
\hline $\mathrm{Si}$ & 1.860 & 1.853 & 1.927 & 1.940 & 1.939 & 1.935 & 1.916 & 1.937 & 1.933 & 1.925 & 1.925 & 1.946 \\
\hline $\mathrm{Ti}$ & 0.003 & 0.009 & 0.000 & 0.005 & 0.000 & 0.000 & 0.000 & 0.005 & 0.007 & 0.002 & 0.000 & 0.000 \\
\hline $\mathrm{Al}$ & 0.203 & 0.218 & 0.106 & 0.094 & 0.086 & 0.092 & 0.112 & 0.081 & 0.098 & 0.092 & 0.096 & 0.091 \\
\hline $\mathrm{Cr}$ & 0.003 & 0.000 & 0.006 & 0.005 & 0.002 & 0.004 & 0.005 & 0.003 & 0.003 & 0.001 & 0.004 & 0.000 \\
\hline $\mathrm{Fe}^{+3}$ & 0.070 & 0.063 & 0.034 & 0.013 & 0.034 & 0.035 & 0.050 & 0.033 & 0.018 & 0.055 & 0.051 & 0.017 \\
\hline $\mathrm{Fe}^{+2}$ & 0.255 & 0.267 & 0.509 & 0.529 & 0.527 & 0.512 & 0.494 & 0.496 & 0.507 & 0.512 & 0.492 & 0.526 \\
\hline $\mathrm{Mn}$ & 0.007 & 0.004 & 0.015 & 0.012 & 0.010 & 0.009 & 0.011 & 0.009 & 0.013 & 0.012 & 0.011 & 0.012 \\
\hline $\mathrm{Mg}$ & 1.571 & 1.509 & 1.390 & 1.387 & 1.386 & 1.395 & 1.398 & 1.425 & 1.405 & 1.381 & 1.405 & 1.392 \\
\hline $\mathrm{Ca}$ & 0.024 & 0.072 & 0.013 & 0.014 & 0.015 & 0.015 & 0.013 & 0.010 & 0.015 & 0.019 & 0.015 & 0.014 \\
\hline En (\%) & 81.793 & 78.958 & 71.429 & 71.367 & 70.636 & 71.283 & 71.480 & 72.576 & 72.241 & 70.212 & 71.601 & 71.400 \\
\hline Amostra & 1-04_c3_px & 1-04_c2_px & 1-04_c2_px & -04_c2_px & px recrist & px recrist & px recrista & px recrist & px recrista & px recrista & x recristal & x recristal \\
\hline Prof. & 276.45 & 276.45 & 276.45 & 276.45 & 209.35 & 209.35 & 209.35 & 209.35 & 209.35 & 209.35 & 209.35 & 209.35 \\
\hline Rocha & Nrt & Nrt & Nrt & Nrt & Pxt & Pxt & Pxt & Pxt & Pxt & Pxt & Pxt & Pxt \\
\hline $\mathrm{SiO}_{2}(\mathrm{wt} \%)$ & 53.274 & 53.196 & 52.929 & 52.806 & 53.864 & 53.579 & 53.651 & 53.347 & 54.052 & 53.83 & 53.709 & 53.508 \\
\hline $\mathrm{TiO}_{2}(\mathrm{wt} \%)$ & 0 & 0 & 0.24 & 0.071 & 0.014 & 0.196 & 0.082 & 0.543 & 0.174 & 0.1 & 0 & 0.145 \\
\hline $\mathrm{Al}_{2} \mathrm{O}_{3}(\mathrm{wt} \%)$ & 2.474 & 2.227 & 2.203 & 2.192 & 1.923 & 1.864 & 1.708 & 2.014 & 1.819 & 1.633 & 1.827 & 2.37 \\
\hline $\mathrm{Cr}_{2} \mathrm{O}_{3}(\mathrm{wt} \%)$ & 0.149 & 0.05 & 0.002 & 0.049 & 0 & 0.049 & 0 & 0 & 0 & 0.075 & 0.011 & 0.074 \\
\hline $\mathrm{FeO}(\mathrm{wt} \%)$ & 17.895 & 19.664 & 19.409 & 19.738 & 17.934 & 17.637 & 17.866 & 17.852 & 17.668 & 16.498 & 16.931 & 16.362 \\
\hline $\mathrm{MnO}(\mathrm{wt} \%)$ & 0.359 & 0.404 & 0.402 & 0.321 & 0.346 & 0.435 & 0.42 & 0.408 & 0.564 & 0.368 & 0.388 & 0.339 \\
\hline $\mathrm{MgO}(\mathrm{wt} \%)$ & 25.829 & 24.597 & 24.687 & 23.955 & 25.946 & 26.152 & 25.684 & 26.014 & 23.827 & 26.851 & 26.446 & 26.225 \\
\hline $\mathrm{CaO}(\mathrm{wt} \%)$ & 0.45 & 0.467 & 0.468 & 0.744 & 0.523 & 0.436 & 0.519 & 0.458 & 0.606 & 0.483 & 0.527 & 0.475 \\
\hline $\mathrm{NiO}$ (wt\%) & 0.029 & 0.039 & 0.047 & 0.01 & 0.092 & 0.069 & 0.055 & 0.106 & 0.025 & 0.059 & 0.069 & 0.086 \\
\hline $\mathrm{BaO}(\mathrm{wt} \%)$ & 0 & 0 & 0 & 0.047 & 0.002 & 0.002 & 0 & 0 & 0 & 0 & 0 & 0 \\
\hline Total & 100.459 & 100.644 & 100.387 & 99.933 & 100.644 & 100.419 & 99.985 & 100.742 & 98.735 & 99.897 & 99.908 & 99.584 \\
\hline $\mathrm{Si}$ & 1.926 & 1.938 & 1.931 & 1.941 & 1.947 & 1.939 & 1.953 & 1.928 & 1.958 & 1.948 & 1.945 & 1.945 \\
\hline $\mathrm{Ti}$ & 0.000 & 0.000 & 0.007 & 0.002 & 0.000 & 0.005 & 0.002 & 0.015 & 0.005 & 0.003 & 0.000 & 0.004 \\
\hline $\mathrm{Al}$ & 0.105 & 0.096 & 0.095 & 0.095 & 0.082 & 0.080 & 0.073 & 0.086 & 0.078 & 0.070 & 0.078 & 0.102 \\
\hline $\mathrm{Cr}$ & 0.004 & 0.001 & 0.000 & 0.001 & 0.000 & 0.001 & 0.000 & 0.000 & 0.000 & 0.002 & 0.000 & 0.002 \\
\hline $\mathrm{Fe}^{+3}$ & 0.039 & 0.028 & 0.033 & 0.019 & 0.024 & 0.031 & 0.018 & 0.029 & 0.000 & 0.027 & 0.035 & 0.000 \\
\hline $\mathrm{Fe}^{+2}$ & 0.502 & 0.571 & 0.559 & 0.587 & 0.518 & 0.503 & 0.526 & 0.510 & 0.508 & 0.472 & 0.478 & 0.497 \\
\hline $\mathrm{Mn}$ & 0.011 & 0.012 & 0.012 & 0.010 & 0.011 & 0.013 & 0.013 & 0.012 & 0.006 & 0.011 & 0.012 & 0.010 \\
\hline $\mathrm{Mg}$ & 1.392 & 1.336 & 1.343 & 1.313 & 1.398 & 1.411 & 1.394 & 1.401 & 1.426 & 1.448 & 1.428 & 1.421 \\
\hline $\mathrm{Ca}$ & 0.017 & 0.018 & 0.018 & 0.029 & 0.020 & 0.017 & 0.020 & 0.018 & 0.017 & 0.019 & 0.020 & 0.018 \\
\hline En (\%) & 71.368 & 68.394 & 68.744 & 67.361 & 71.315 & 71.926 & 71.187 & 71.550 & 73.078 & 73.659 & 72.808 & 73.367 \\
\hline Amostra & $x$ recr & $x$ recris & 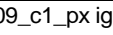 & $1 \_p x$ & c1_px & 9_c1_pxig & c1_pxign & c1_px igr & c1_px ign & px recrist & px recrist & px recrista \\
\hline Prof. & 209.35 & 209.35 & 209.35 & 209.35 & 209.35 & 209.35 & 209.35 & 209.35 & 209.35 & 209.35 & 209.35 & 209.35 \\
\hline Rocha & Pxt & Pxt & Pxt & Pxt & Pxt & Pxt & Pxt & Pxt & Pxt & Pxt & Pxt & Pxt \\
\hline $\mathrm{SiO}_{2}(\mathrm{wt} \%)$ & 53.71 & 53.456 & 53.466 & 52.95 & 53.199 & 53.038 & 52.591 & 52.42 & 52.42 & 53.959 & 53.268 & 52.797 \\
\hline $\mathrm{TiO}_{2}(\mathrm{wt} \%)$ & 0.029 & 0.179 & 0 & 0.101 & 0.063 & 0.315 & 0.146 & 0.146 & 0.146 & 0 & 0.234 & 0.134 \\
\hline $\mathrm{Al}_{2} \mathrm{O}_{3}(\mathrm{wt} \%)$ & 1.611 & 1.77 & 3.54 & 3.351 & 3.42 & 3.676 & 4.677 & 4.608 & 4.608 & 1.837 & 1.74 & 1.659 \\
\hline $\mathrm{Cr}_{2} \mathrm{O}_{3}(\mathrm{wt} \%)$ & 0.025 & 0 & 0.101 & 0.113 & 0.161 & 0.102 & 0.062 & 0.175 & 0.175 & 0.037 & 0.062 & 0.034 \\
\hline $\mathrm{FeO}(w t \%)$ & 16.842 & 16.862 & 15.564 & 15.36 & 15.359 & 14.648 & 14.079 & 13.692 & 13.692 & 18.388 & 18.581 & 19.119 \\
\hline $\mathrm{MnO}(\mathrm{wt} \%)$ & 0.45 & 0.395 & 0.35 & 0.419 & 0.288 & 0.289 & 0.206 & 0.15 & 0.15 & 0.538 & 0.529 & 0.528 \\
\hline $\mathrm{MgO}(\mathrm{wt} \%)$ & 26.516 & 26.527 & 27.726 & 27.075 & 26.838 & 28.081 & 26.898 & 27.873 & 27.873 & 25.205 & 24.897 & 24.961 \\
\hline $\mathrm{CaO}(\mathrm{wt} \%)$ & 0.432 & 0.407 & 0.362 & 0.433 & 0.348 & 0.324 & 1.577 & 0.639 & 0.639 & 0.494 & 0.548 & 0.48 \\
\hline $\mathrm{NiO}$ (wt\%) & 0.037 & 0.018 & 0.08 & 0.053 & 0.027 & 0.002 & 0.07 & 0.014 & 0.014 & 0.02 & 0.045 & 0.012 \\
\hline $\mathrm{BaO}(\mathrm{wt} \%)$ & 0 & 0 & 0 & 0.008 & 0.081 & 0.025 & 0 & 0 & 0 & 0.047 & 0.045 & 0.006 \\
\hline Total & 99.652 & 99.614 & 101.189 & 99.863 & 99.784 & 100.5 & 100.306 & 99.717 & 99.717 & 100.525 & 99.949 & 99.73 \\
\hline $\mathrm{Si}$ & 1.950 & 1.942 & 1.897 & 1.906 & 1.919 & 1.887 & 1.878 & 1.872 & 1.872 & 1.960 & 1.951 & 1.936 \\
\hline $\mathrm{Ti}$ & 0.001 & 0.005 & 0.000 & 0.003 & 0.002 & 0.008 & 0.004 & 0.004 & 0.004 & 0.000 & 0.006 & 0.004 \\
\hline $\mathrm{Al}$ & 0.069 & 0.076 & 0.148 & 0.142 & 0.145 & 0.154 & 0.197 & 0.194 & 0.194 & 0.079 & 0.075 & 0.072 \\
\hline $\mathrm{Cr}$ & 0.001 & 0.000 & 0.003 & 0.003 & 0.005 & 0.003 & 0.002 & 0.005 & 0.005 & 0.001 & 0.002 & 0.001 \\
\hline $\mathrm{Fe}^{+3}$ & 0.031 & 0.030 & 0.056 & 0.037 & 0.008 & 0.054 & 0.037 & 0.052 & 0.052 & 0.003 & 0.009 & 0.047 \\
\hline $\mathrm{Fe}^{+2}$ & 0.481 & 0.482 & 0.406 & 0.426 & 0.455 & 0.381 & 0.384 & 0.357 & 0.357 & 0.556 & 0.560 & 0.539 \\
\hline $\mathrm{Mn}$ & 0.014 & 0.012 & 0.011 & 0.013 & 0.009 & 0.009 & 0.006 & 0.005 & 0.005 & 0.017 & 0.016 & 0.016 \\
\hline $\mathrm{Mg}$ & 1.435 & 1.437 & 1.466 & 1.453 & 1.443 & 1.489 & 1.432 & 1.484 & 1.484 & 1.365 & 1.359 & 1.365 \\
\hline $\mathrm{Ca}$ & 0.017 & 0.016 & 0.014 & 0.017 & 0.013 & 0.012 & 0.060 & 0.024 & 0.024 & 0.019 & 0.022 & 0.019 \\
\hline En (\%) & 73.098 & 73.120 & 75.512 & 75.202 & 75.168 & 76.869 & 74.863 & 77.397 & 77.397 & 70.257 & 69.711 & 69.276 \\
\hline
\end{tabular}




\begin{tabular}{|c|c|c|c|c|c|c|c|c|c|c|c|c|}
\hline Amostra & c2_px recristal2 & px recristali 2 & 2_px recristali & 2 px recristali 2 & 2_px recristali 2 & 2_px recristali c & 2_px recristalc2 & 2_px recristalce & 2__px recristal 0 & 0_c2_px reliqu0 & c2_px reliqui & i 0_c2_px reliqu \\
\hline Prof. & 209.35 & 209.35 & 209.35 & 209.35 & 209.35 & 209.35 & 209.35 & 209.35 & 209.35 & 209.45 & 209.45 & 209.45 \\
\hline Rocha & Pxt & Pxt & Pxt & Pxt & Pxt & Pxt & Pxt & Pxt & Pxt & Pxt & Pxt & Pxt \\
\hline $\mathrm{SiO}_{2}(\mathrm{wt} \%)$ & 53.366 & 53.509 & 52.716 & 53.277 & 53.647 & 53.636 & 52.428 & 52.53 & 53.757 & 52.368 & 52.861 & 53.48 \\
\hline $\mathrm{TiO}_{2}$ (wt\%) & 0.068 & 0.154 & 0.144 & 0.235 & 0.076 & 0.11 & 0.171 & 0.269 & 0.083 & 0.529 & 0.19 & 0.14 \\
\hline $\mathrm{Al}_{2} \mathrm{O}_{3}(\mathrm{wt} \%)$ & 1.985 & 1.075 & 1.594 & 1.786 & 1.306 & 1.145 & 1.798 & 2.124 & 1.29 & 4.515 & 4.587 & 3.552 \\
\hline $\mathrm{Cr}_{2} \mathrm{O}_{3}(\mathrm{wt} \%)$ & 0 & 0.037 & 0.014 & 0.06 & 0.036 & 0 & 0.009 & 0 & 0.038 & 0.175 & 0.064 & 0.061 \\
\hline $\mathrm{FeO}(\mathrm{wt} \%)$ & 18.732 & 19.693 & 19.848 & 20.005 & 20.405 & 20.161 & 20.683 & 19.975 & 17.592 & 14.057 & 14.205 & 14.417 \\
\hline $\mathrm{MnO}(\mathrm{wt} \%)$ & 0.448 & 0.414 & 0.562 & 0.564 & 0.479 & 0.442 & 0.394 & 0.532 & 0.417 & 0.196 & 0.203 & 0.421 \\
\hline $\mathrm{MgO}(\mathrm{wt} \%)$ & 25.497 & 24.393 & 24.262 & 24.585 & 24.939 & 24.398 & 23.862 & 24.08 & 25.421 & 26.634 & 26.753 & 27.871 \\
\hline $\mathrm{CaO}(\mathrm{wt} \%)$ & 0.494 & 0.4 & 0.594 & 0.571 & 0.549 & 0.599 & 0.567 & 0.521 & 1.665 & 1.547 & 1.31 & 0.305 \\
\hline $\mathrm{NiO}$ (wt\%) & 0.092 & 0.055 & 0.026 & 0 & 0.045 & 0.067 & 0.065 & 0.041 & 0.049 & 0 & 0 & 0 \\
\hline $\mathrm{BaO}(\mathrm{wt} \%)$ & 0 & 0.004 & 0.142 & 0.037 & 0.023 & 0 & 0 & 0 & 0.028 & 0.023 & 0 & 0 \\
\hline Total & 100.682 & 99.734 & 99.902 & 101.12 & 101.505 & 100.558 & 99.977 & 100.072 & 100.34 & 100.044 & 100.173 & 100.247 \\
\hline $\mathrm{Si}$ & 1.935 & 1.972 & 1.940 & 1.935 & 1.942 & 1.963 & 1.932 & 1.929 & 1.952 & 1.877 & 1.890 & 1.907 \\
\hline $\mathrm{Ti}$ & 0.002 & 0.004 & 0.004 & 0.006 & 0.002 & 0.003 & 0.005 & 0.007 & 0.002 & 0.014 & 0.005 & 0.004 \\
\hline $\mathrm{Al}$ & 0.085 & 0.047 & 0.069 & 0.076 & 0.056 & 0.049 & 0.078 & 0.092 & 0.055 & 0.191 & 0.193 & 0.149 \\
\hline $\mathrm{Cr}$ & 0.000 & 0.001 & 0.000 & 0.002 & 0.001 & 0.000 & 0.000 & 0.000 & 0.001 & 0.005 & 0.002 & 0.002 \\
\hline $\mathrm{Fe}^{+3}$ & 0.042 & 0.000 & 0.047 & 0.041 & 0.055 & 0.019 & 0.049 & 0.038 & 0.035 & 0.025 & 0.018 & 0.029 \\
\hline $\mathrm{Fe}^{+2}$ & 0.526 & 0.607 & 0.563 & 0.567 & 0.562 & 0.598 & 0.589 & 0.575 & 0.499 & 0.396 & 0.407 & 0.401 \\
\hline $\mathrm{Mn}$ & 0.014 & 0.013 & 0.018 & 0.017 & 0.015 & 0.014 & 0.012 & 0.017 & 0.013 & 0.006 & 0.006 & 0.013 \\
\hline $\mathrm{Mg}$ & 1.378 & 1.340 & 1.331 & 1.331 & 1.346 & 1.331 & 1.311 & 1.318 & 1.376 & 1.423 & 1.426 & 1.482 \\
\hline $\mathrm{Ca}$ & 0.019 & 0.016 & 0.023 & 0.022 & 0.021 & 0.023 & 0.022 & 0.020 & 0.065 & 0.059 & 0.050 & 0.012 \\
\hline En (\%) & 70.123 & 68.274 & 67.727 & 67.881 & 67.805 & 67.513 & 66.519 & 67.527 & 69.673 & 74.748 & 75.016 & 77.039 \\
\hline Amostra & 0_c2_px reliqui & Dc1_px reliqu & u_c1_px reliqui & di 0_c1_px reliqu & 0_c1_px reliqu0 & 0_c1_px reliq⿴囗十 & M-20_c1_px DN & M-20_c1_px 2M- & 1-20_c1_px 2.M- & 1-20_c1_px 2.M & 1-20_c1_px 2.N & M-20_c1_px 2. \\
\hline Prof. & 209.45 & 209.45 & 209.45 & 209.45 & 209.45 & 209.45 & 0 & 0 & 0 & 0 & 0 & 0 \\
\hline Rocha & Pxt & Pxt & Pxt & Pxt & Pxt & Pxt & GR & GR & GR & GR & GR & GR \\
\hline $\mathrm{SiO}_{2}(\mathrm{wt} \%)$ & 53.458 & 51.935 & 52.821 & 53.415 & 53.582 & 52.975 & 51.245 & 50.902 & 50.407 & 50.518 & 50.299 & 50.238 \\
\hline $\mathrm{TiO}_{2}$ (wt\%) & 0.262 & 0.196 & 0.267 & 0.111 & 0 & 0.203 & 0.246 & 0.189 & 0.124 & 0 & 0.166 & 0.09 \\
\hline $\mathrm{Al}_{2} \mathrm{O}_{3}(\mathrm{wt} \%)$ & 3.548 & 5.261 & 4.623 & 4.269 & 3.671 & 3.553 & 1.47 & 1.813 & 1.902 & 2.113 & 1.849 & 1.823 \\
\hline $\mathrm{Cr}_{2} \mathrm{O}_{3}(\mathrm{wt} \%)$ & 0 & 0.062 & 0.049 & 0.088 & 0.162 & 0.137 & 0.025 & 0.083 & 0.073 & 0 & 0.024 & 0 \\
\hline $\mathrm{FeO}$ (wt\%) & 14.648 & 13.111 & 13.948 & 13.812 & 13.703 & 13.991 & 27.367 & 27.299 & 26.726 & 27.125 & 27.315 & 27.173 \\
\hline $\mathrm{MnO}(\mathrm{wt} \%)$ & 0.11 & 0.249 & 0.173 & 0.42 & 0.375 & 0.255 & 0.682 & 0.649 & 0.486 & 0.584 & 0.718 & 0.524 \\
\hline $\mathrm{MgO}(\mathrm{wt} \%)$ & 27.706 & 26.81 & 28.275 & 27.892 & 28.879 & 28.574 & 18.414 & 18.154 & 18.149 & 18.684 & 18.385 & 18.678 \\
\hline $\mathrm{CaO}(\mathrm{wt} \%)$ & 0.887 & 2.204 & 0.343 & 0.346 & 0.314 & 0.255 & 0.656 & 0.941 & 1.25 & 0.931 & 0.847 & 0.619 \\
\hline $\mathrm{NiO}$ (wt\%) & 0.098 & 0.061 & 0 & 0.045 & 0.025 & 0.031 & 0.032 & 0.024 & 0 & 0 & 0 & 0 \\
\hline $\mathrm{BaO}(\mathrm{wt} \%)$ & 0.004 & 0.017 & 0 & 0 & 0 & 0 & 0 & 0.037 & 0.146 & 0 & 0 & 0.019 \\
\hline Total & 100.721 & 99.906 & 100.499 & 100.398 & 100.711 & 99.974 & 100.137 & 100.091 & 99.263 & 99.955 & 99.603 & 99.164 \\
\hline $\mathrm{Si}$ & 1.902 & 1.855 & 1.872 & 1.899 & 1.892 & 1.888 & 1.955 & 1.945 & 1.939 & 1.924 & 1.927 & 1.929 \\
\hline $\mathrm{Ti}$ & 0.007 & 0.005 & 0.007 & 0.003 & 0.000 & 0.005 & 0.007 & 0.005 & 0.004 & 0.000 & 0.005 & 0.003 \\
\hline $\mathrm{Al}$ & 0.149 & 0.221 & 0.193 & 0.179 & 0.153 & 0.149 & 0.066 & 0.082 & 0.086 & 0.095 & 0.084 & 0.083 \\
\hline $\mathrm{Cr}$ & 0.000 & 0.002 & 0.001 & 0.002 & 0.005 & 0.004 & 0.001 & 0.003 & 0.002 & 0.000 & 0.001 & 0.000 \\
\hline $\mathrm{Fe}^{+3}$ & 0.033 & 0.061 & 0.049 & 0.017 & 0.060 & 0.059 & 0.012 & 0.016 & 0.029 & 0.058 & 0.051 & 0.055 \\
\hline $\mathrm{Fe}+2$ & 0.402 & 0.330 & 0.364 & 0.393 & 0.345 & 0.358 & 0.861 & 0.857 & 0.831 & 0.806 & 0.824 & 0.818 \\
\hline $\mathrm{Mn}$ & 0.003 & 0.008 & 0.005 & 0.013 & 0.011 & 0.008 & 0.022 & 0.021 & 0.016 & 0.019 & 0.023 & 0.017 \\
\hline $\mathrm{Mg}$ & 1.469 & 1.428 & 1.494 & 1.478 & 1.521 & 1.518 & 1.047 & 1.034 & 1.041 & 1.061 & 1.050 & 1.069 \\
\hline $\mathrm{Ca}$ & 0.034 & 0.084 & 0.013 & 0.013 & 0.012 & 0.010 & 0.027 & 0.039 & 0.052 & 0.038 & 0.035 & 0.025 \\
\hline En (\%) & 75.781 & 74.995 & 77.794 & 77.718 & 78.493 & 78.058 & 53.783 & 53.168 & 53.316 & 54.047 & 53.574 & 54.350 \\
\hline Amostra & M-20_c1_px 2DI & 1-20_c1_px ד & M-20_c1_px 5 & & & & & & & & & \\
\hline Prof. & 0 & 0 & 0 & & & & & & & & & \\
\hline Rocha & GR & GR & GR & & & & & & & & & \\
\hline $\mathrm{SiO}_{2}(\mathrm{wt} \%)$ & 50.431 & 50.598 & 50.373 & & & & & & & & & \\
\hline $\mathrm{TiO}_{2}(w t \%)$ & 0.028 & 0.142 & 0.152 & & & & & & & & & \\
\hline $\mathrm{Al}_{2} \mathrm{O}_{3}(\mathrm{wt} \%)$ & 1.658 & 2.009 & 1.68 & & & & & & & & & \\
\hline $\mathrm{Cr}_{2} \mathrm{O}_{3}(\mathrm{wt} \%)$ & 0 & 0 & 0.024 & & & & & & & & & \\
\hline $\mathrm{FeO}(\mathrm{wt} \%)$ & 27.155 & 27.03 & 27.227 & & & & & & & & & \\
\hline $\mathrm{MnO}(\mathrm{wt} \%)$ & 0.731 & 0.738 & 0.827 & & & & & & & & & \\
\hline $\mathrm{MgO}(\mathrm{wt} \%)$ & 18.458 & 18.261 & 18.534 & & & & & & & & & \\
\hline $\mathrm{CaO}(\mathrm{wt} \%)$ & 0.651 & 0.853 & 0.666 & & & & & & & & & \\
\hline $\mathrm{NiO}$ (wt\%) & 0.018 & 0 & 0.049 & & & & & & & & & \\
\hline $\mathrm{BaO}(\mathrm{wt} \%)$ & 0.098 & 0.157 & 0.017 & & & & & & & & & \\
\hline Total & 99.228 & 99.788 & 99.549 & & & & & & & & & \\
\hline $\mathrm{Si}$ & 1.940 & 1.937 & 1.926 & & & & & & & & & \\
\hline $\mathrm{Ti}$ & 0.001 & 0.004 & 0.004 & & & & & & & & & \\
\hline $\mathrm{Al}$ & 0.075 & 0.091 & 0.076 & & & & & & & & & \\
\hline $\mathrm{Cr}$ & 0.000 & 0.000 & 0.001 & & & & & & & & & \\
\hline $\mathrm{Fe}^{+3}$ & 0.046 & 0.028 & 0.075 & & & & & & & & & \\
\hline $\mathrm{Fe}+2$ & 0.827 & 0.838 & 0.796 & & & & & & & & & \\
\hline $\mathrm{Mn}$ & 0.024 & 0.024 & 0.027 & & & & & & & & & \\
\hline $\mathrm{Mg}$ & 1.058 & 1.042 & 1.056 & & & & & & & & & \\
\hline $\mathrm{Ca}$ & 0.027 & 0.035 & 0.027 & & & & & & & & & \\
\hline En (\%) & 54.035 & 53.650 & 54.056 & & & & & & & & & \\
\hline
\end{tabular}




\section{CLINOPIROXÊNIO}

\begin{tabular}{|c|c|c|c|c|c|c|c|c|c|c|c|c|}
\hline Amostra & 3_px recris & px recris & ox recrista & 06_c2_! & 11_c1_px & 11_c1_p & 11_c1_F & $-04 \_c 4 \_p x$ 30 & 3c3_px recriste & px recris & 3_px recristalc & 3_px recris \\
\hline Prof. & 220.2 & 220.2 & 220.2 & 220.2 & 177.5 & 177.5 & 177.5 & 276.45 & 209.35 & 209.35 & 209.35 & 209.35 \\
\hline Rocha & Xnt & Xnt & Xnt & Xnt & $\mathrm{Hzb}$ & $\mathrm{Hzb}$ & $\mathrm{Hzb}$ & Nrt & Pxt & Pxt & Pxt & Pxt \\
\hline $\mathrm{SiO}_{2}(\mathrm{wt} \%)$ & 52.039 & 51.718 & 51.796 & 57.86 & 50.953 & 51.37 & 50.934 & 51.216 & 51.99 & 48.336 & 51.444 & 50.917 \\
\hline $\mathrm{TiO}_{2}(\mathrm{wt} \%)$ & 0.255 & 0.412 & 0.572 & 0.12 & 0.559 & 0.719 & 0.931 & 0.565 & 0.866 & 0.044 & 0.914 & 0.954 \\
\hline $\mathrm{Al}_{2} \mathrm{O}_{3}(\mathrm{wt} \%)$ & 3.038 & 3.115 & 2.999 & 25.95 & 4.677 & 3.617 & 4.838 & 4.348 & 3.394 & 33.066 & 3.909 & 4.261 \\
\hline $\mathrm{Cr}_{2} \mathrm{O}_{3}(\mathrm{wt} \%)$ & 0.063 & 0.063 & 0.102 & 0 & 0.286 & 0.143 & 0.29 & 0.053 & 0.066 & 0 & 0.118 & 0.195 \\
\hline $\mathrm{FeO}(\mathrm{wt} \%)$ & 7.483 & 8.263 & 7.575 & 0.167 & 3.796 & 4.68 & 3.327 & 6.608 & 6.679 & 0.104 & 6.081 & 6.294 \\
\hline $\mathrm{MnO}(\mathrm{wt} \%)$ & 0.296 & 0.147 & 0.235 & 0 & 0.158 & 0.101 & 0.007 & 0.227 & 0.159 & 0 & 0.158 & 0.138 \\
\hline $\mathrm{MgO}(\mathrm{wt} \%)$ & 14.219 & 14.255 & 14.352 & 0.006 & 16.136 & 17.56 & 16.071 & 13.656 & 14.8 & 0.007 & 14.474 & 14.32 \\
\hline $\mathrm{CaO}(\mathrm{wt} \%)$ & 21.714 & 21.229 & 21.912 & 7.912 & 22.996 & 21.651 & 23.58 & 22.347 & 21.905 & 16.021 & 22.367 & 22.794 \\
\hline $\mathrm{NiO}(\mathrm{wt} \%)$ & 0 & 0.041 & 0 & 0.045 & 0 & 0.045 & 0.027 & 0 & 0.002 & 0.029 & 0 & 0.025 \\
\hline $\mathrm{BaO}(\mathrm{wt} \%)$ & 0 & 0.133 & 0.02 & 0.102 & 0 & 0 & 0.047 & 0.016 & 0.031 & 0.055 & 0 & 0 \\
\hline $\mathrm{Na}_{2} \mathrm{O}(\mathrm{wt} \%)$ & 0.653 & 0.582 & 0.561 & 7.185 & 0.249 & 0.113 & 0.18 & 0.454 & 0.481 & 2.398 & 0.537 & 0.422 \\
\hline Total & 99.76 & 99.958 & 100.124 & 99.347 & 99.81 & 99.999 & 100.232 & 99.49 & 100.373 & 100.06 & 100.002 & 100.32 \\
\hline $\mathrm{Si}$ & 1.926 & 1.917 & 1.912 & 2.083 & 1.860 & 1.870 & 1.853 & 1.902 & 1.910 & 1.770 & 1.894 & 1.872 \\
\hline $\mathrm{Ti}$ & 0.007 & 0.011 & 0.016 & 0.003 & 0.015 & 0.020 & 0.025 & 0.016 & 0.024 & 0.001 & 0.025 & 0.026 \\
\hline Al & 0.132 & 0.136 & 0.131 & 1.101 & 0.201 & 0.155 & 0.207 & 0.190 & 0.147 & 1.427 & 0.170 & 0.185 \\
\hline $\mathrm{Cr}$ & 0.002 & 0.002 & 0.003 & 0.000 & 0.008 & 0.004 & 0.008 & 0.002 & 0.002 & 0.000 & 0.003 & 0.006 \\
\hline $\mathrm{Fe}^{+3}$ & 0.047 & 0.047 & 0.050 & 0.000 & 0.058 & 0.069 & 0.039 & 0.005 & 0.018 & 0.000 & 0.026 & 0.042 \\
\hline $\mathrm{Fe}_{+2}$ & 0.185 & 0.209 & 0.184 & 0.005 & 0.058 & 0.073 & 0.062 & 0.200 & 0.188 & 0.003 & 0.161 & 0.151 \\
\hline $\mathrm{Mn}$ & 0.009 & 0.005 & 0.007 & 0.000 & 0.005 & 0.003 & 0.000 & 0.007 & 0.005 & 0.000 & 0.005 & 0.004 \\
\hline $\mathrm{Mg}$ & 0.784 & 0.788 & 0.790 & 0.000 & 0.878 & 0.953 & 0.872 & 0.756 & 0.811 & 0.000 & 0.794 & 0.785 \\
\hline $\mathrm{Ca}$ & 0.861 & 0.843 & 0.867 & 0.305 & 0.899 & 0.844 & 0.919 & 0.889 & 0.862 & 0.628 & 0.882 & 0.898 \\
\hline $\mathrm{Na}$ & 0.047 & 0.042 & 0.040 & 0.502 & 0.018 & 0.008 & 0.013 & 0.033 & 0.034 & 0.170 & 0.038 & 0.030 \\
\hline Wo (\%) & 45.869 & 44.680 & 45.847 & 98.277 & 47.502 & 43.531 & 48.580 & 48.052 & 45.912 & 99.436 & 47.335 & 47.855 \\
\hline En (\%) & 41.793 & 41.745 & 41.782 & 0.104 & 46.377 & 49.124 & 46.069 & 40.857 & 43.161 & 0.060 & 42.620 & 41.831 \\
\hline Amostra & c3_px recristal-0 & 9_c3_px igne & 9_c3_px igneo9 & c3_px igneo9 & c3_px igneo9 & c3_px igneo9 & c3_px igneo9 & 9_c3_px igneo9 & 9_c3_px igneo9_ & c3_px igneo9 & c3_px igneoc3_p & px recristal \\
\hline Prof. & 209.35 & 209.35 & 209.35 & 209.35 & 209.35 & 209.35 & 209.35 & 209.35 & 209.35 & 209.35 & 209.35 & 209.35 \\
\hline Rocha & Pxt & Pxt & Pxt & Pxt & Pxt & Pxt & Pxt & Pxt & Pxt & Pxt & Pxt & Pxt \\
\hline $\mathrm{SiO}_{2}(\mathrm{wt} \%)$ & 51.07 & 49.851 & 49.829 & 49.523 & 49.177 & 49.77 & 51.14 & 49.739 & 49.581 & 50.068 & 52.084 & 45.89 \\
\hline $\mathrm{TiO}_{2}(\mathrm{wt} \%)$ & 0.957 & 0.928 & 0.718 & 1.133 & 0.839 & 0.887 & 0.078 & 0.753 & 0.664 & 0.783 & 0.707 & 0.046 \\
\hline $\mathrm{Al}_{2} \mathrm{O}_{3}(\mathrm{wt} \%)$ & 4.183 & 5.306 & 6.305 & 6.848 & 7.059 & 6.275 & 5.435 & 6.872 & 6.38 & 5.511 & 3.407 & 34.752 \\
\hline $\mathrm{Cr}_{2} \mathrm{O}_{3}(\mathrm{wt} \%)$ & 0.119 & 0.09 & 0.054 & 0.157 & 0.158 & 0.141 & 0.074 & 0.155 & 0.142 & 0.195 & 0.129 & 0.002 \\
\hline $\mathrm{FeO}(\mathrm{wt} \%)$ & 6.268 & 5.948 & 5.749 & 6.082 & 6.414 & 6.304 & 17.668 & 8.33 & 6.471 & 6.331 & 6.442 & 0.431 \\
\hline $\mathrm{MnO}(\mathrm{wt} \%)$ & 0.21 & 0.119 & 0.231 & 0.156 & 0.053 & 0.166 & 0.564 & 0.36 & 0.117 & 0.233 & 0.103 & 0.053 \\
\hline $\mathrm{MgO}(\mathrm{wt} \%)$ & 14.293 & 13.974 & 13.27 & 13.08 & 13.189 & 13.563 & 23.827 & 14.891 & 13.138 & 13.698 & 14.428 & 0.014 \\
\hline $\mathrm{CaO}(\mathrm{wt} \%)$ & 22.419 & 23.136 & 22.883 & 22.889 & 22.824 & 22.93 & 0.606 & 18.82 & 22.985 & 22.665 & 22.646 & 17.948 \\
\hline $\mathrm{NiO}$ (wt\%) & 0 & 0.055 & 0.051 & 0.059 & 0 & 0.035 & 0.025 & 0.123 & 0 & 0.047 & 0.047 & 0.068 \\
\hline $\mathrm{BaO}(\mathrm{wt} \%)$ & 0.008 & 0.022 & 0.016 & 0 & 0 & 0.006 & 0 & 0 & 0.01 & 0.108 & 0.018 & 0 \\
\hline $\mathrm{Na}_{2} \mathrm{O}$ (wt\%) & 0.467 & 0.436 & 0.395 & 0.421 & 0.443 & 0.406 & 0.007 & 0.556 & 0.427 & 0.406 & 0.434 & 1.199 \\
\hline Total & 99.994 & 99.865 & 99.501 & 100.348 & 100.156 & 100.483 & 99.424 & 100.599 & 99.915 & 100.045 & 100.445 & 100.403 \\
\hline $\mathrm{Si}$ & 1.883 & 1.839 & 1.847 & 1.824 & 1.811 & 1.828 & 1.875 & 1.821 & 1.832 & 1.849 & 1.914 & 1.686 \\
\hline $\mathrm{Ti}$ & 0.027 & 0.026 & 0.020 & 0.031 & 0.023 & 0.024 & 0.002 & 0.021 & 0.018 & 0.022 & 0.020 & 0.001 \\
\hline $\mathrm{Al}$ & 0.182 & 0.231 & 0.275 & 0.297 & 0.306 & 0.272 & 0.235 & 0.297 & 0.278 & 0.240 & 0.148 & 1.505 \\
\hline $\mathrm{Cr}$ & 0.003 & 0.003 & 0.002 & 0.005 & 0.005 & 0.004 & 0.002 & 0.004 & 0.004 & 0.006 & 0.004 & 0.000 \\
\hline $\mathrm{Fe}^{+3}$ & 0.028 & 0.068 & 0.017 & 0.018 & 0.053 & 0.049 & 0.009 & 0.054 & 0.048 & 0.041 & 0.012 & 0.000 \\
\hline $\mathrm{Fe}^{+2}$ & 0.165 & 0.116 & 0.161 & 0.169 & 0.145 & 0.145 & 0.533 & 0.201 & 0.152 & 0.154 & 0.186 & 0.013 \\
\hline $\mathrm{Mn}$ & 0.007 & 0.004 & 0.007 & 0.005 & 0.002 & 0.005 & 0.018 & 0.011 & 0.004 & 0.007 & 0.003 & 0.002 \\
\hline $\mathrm{Mg}$ & 0.786 & 0.769 & 0.733 & 0.718 & 0.724 & 0.742 & 1.302 & 0.813 & 0.724 & 0.754 & 0.791 & 0.001 \\
\hline $\mathrm{Ca}$ & 0.886 & 0.915 & 0.909 & 0.903 & 0.900 & 0.902 & 0.024 & 0.738 & 0.910 & 0.897 & 0.892 & 0.707 \\
\hline $\mathrm{Na}$ & 0.033 & 0.031 & 0.028 & 0.030 & 0.032 & 0.029 & 0.000 & 0.039 & 0.031 & 0.029 & 0.031 & 0.085 \\
\hline Wo (\%) & 47.499 & 48.994 & 49.926 & 49.937 & 49.422 & 49.077 & 1.274 & 40.876 & 49.626 & 48.569 & 47.427 & 98.056 \\
\hline En (\%) & 42.135 & 41.174 & 40.284 & 39.706 & 39.737 & 40.391 & 69.723 & 45.002 & 39.468 & 40.842 & 42.043 & 0.106 \\
\hline
\end{tabular}




\begin{tabular}{|c|c|c|c|c|c|c|c|c|c|c|c|c|}
\hline Amostra & c3_px recris & 0_c1_px & $0 \_c 1 \_p \times 2$ & 3_px rescrista & a 3_px rescrista & 3_px rescrista & B_c1_px 1 & 18_c1_px & 8_c1_px 3 & 1-18_c1_px & 18_c1_px 5 & M-20_c2_px \\
\hline Prof. & 209.35 & 209.45 & 209.45 & 209.45 & 209.45 & 209.45 & 0 & 0 & 0 & 0 & 0 & 0 \\
\hline Rocha & Pxt & Pxt & Pxt & Pxt & Pxt & Pxt & GR & GR & GR & GR & GR & GR \\
\hline $\mathrm{SiO}_{2}(\mathrm{wt} \%)$ & 44.828 & 44.847 & 44.148 & 49.689 & 49.505 & 50.38 & 50.217 & 49.61 & 50.543 & 49.984 & 50.776 & 50.302 \\
\hline $\mathrm{TiO}_{2}$ (wt\%) & 0.126 & 0.085 & 0.116 & 0.306 & 1.25 & 1.025 & 0.227 & 0.311 & 0.679 & 0.633 & 0.256 & 0.539 \\
\hline $\mathrm{Al}_{2} \mathrm{O}_{3}(\mathrm{wt} \%)$ & 34.77 & 35.601 & 35.641 & 6.47 & 5.233 & 5.091 & 2.685 & 3.019 & 2.758 & 2.596 & 2.694 & 3.334 \\
\hline $\mathrm{Cr}_{2} \mathrm{O}_{3}(\mathrm{wt} \%)$ & 0 & 0.016 & 0 & 0.026 & 0.155 & 0.118 & 0 & 0.037 & 0.014 & 0 & 0.013 & 0 \\
\hline $\mathrm{FeO}(\mathrm{wt} \%)$ & 0.439 & 0.221 & 0.191 & 10.485 & 5.672 & 5.314 & 14.326 & 15.712 & 13.109 & 14.532 & 13.293 & 13.458 \\
\hline $\mathrm{MnO}(\mathrm{wt} \%)$ & 0.083 & 0 & 0.03 & 0.154 & 0.109 & 0.21 & 0.559 & 0.539 & 0.553 & 0.587 & 0.536 & 0.322 \\
\hline $\mathrm{MgO}(\mathrm{wt} \%)$ & 0.028 & 0.008 & 0.014 & 18.534 & 14.382 & 14.365 & 10.719 & 10.916 & 10.896 & 11.035 & 10.995 & 12.235 \\
\hline $\mathrm{CaO}(\mathrm{wt} \%)$ & 18.637 & 18.972 & 19.017 & 13.173 & 23.506 & 23.46 & 19.846 & 17.695 & 20.957 & 19.326 & 20.541 & 19.164 \\
\hline $\mathrm{NiO}(\mathrm{wt} \%)$ & 0 & 0.006 & 0.01 & 0 & 0.039 & 0 & 0.047 & 0 & 0 & 0 & 0.071 & 0 \\
\hline $\mathrm{BaO}(\mathrm{wt} \%)$ & 0 & 0 & 0 & 0 & 0.03 & 0 & 0 & 0 & 0 & 0 & 0.016 & 0 \\
\hline $\mathrm{Na}_{2} \mathrm{O}(\mathrm{wt} \%)$ & 0.92 & 0.923 & 0.587 & 0.226 & 0.222 & 0.212 & 0.563 & 0.505 & 0.712 & 0.563 & 0.63 & 0.499 \\
\hline Total & 99.831 & 100.679 & 99.754 & 99.063 & 100.103 & 100.175 & 99.189 & 98.344 & 100.221 & 99.256 & 99.821 & 99.853 \\
\hline $\mathrm{Si}$ & 1.658 & 1.643 & 1.636 & 1.829 & 1.823 & 1.852 & 1.925 & 1.922 & 1.910 & 1.915 & 1.928 & 1.900 \\
\hline $\mathrm{Ti}$ & 0.004 & 0.002 & 0.003 & 0.008 & 0.035 & 0.028 & 0.007 & 0.009 & 0.019 & 0.018 & 0.007 & 0.015 \\
\hline $\mathrm{Al}$ & 1.516 & 1.537 & 1.556 & 0.281 & 0.227 & 0.221 & 0.121 & 0.138 & 0.123 & 0.117 & 0.121 & 0.148 \\
\hline $\mathrm{Cr}$ & 0.000 & 0.000 & 0.000 & 0.001 & 0.005 & 0.003 & 0.000 & 0.001 & 0.000 & 0.000 & 0.000 & 0.000 \\
\hline $\mathrm{Fe}+3$ & 0.000 & 0.000 & 0.000 & 0.059 & 0.069 & 0.031 & 0.057 & 0.037 & 0.069 & 0.059 & 0.055 & 0.058 \\
\hline $\mathrm{Fe}^{+2}$ & 0.014 & 0.007 & 0.006 & 0.264 & 0.106 & 0.132 & 0.402 & 0.473 & 0.345 & 0.407 & 0.367 & 0.367 \\
\hline $\mathrm{Mn}$ & 0.003 & 0.000 & 0.001 & 0.005 & 0.003 & 0.007 & 0.018 & 0.018 & 0.018 & 0.019 & 0.017 & 0.010 \\
\hline $\mathrm{Mg}$ & 0.002 & 0.000 & 0.001 & 1.017 & 0.790 & 0.787 & 0.613 & 0.631 & 0.614 & 0.630 & 0.622 & 0.689 \\
\hline $\mathrm{Ca}$ & 0.739 & 0.745 & 0.755 & 0.520 & 0.927 & 0.924 & 0.815 & 0.735 & 0.849 & 0.793 & 0.836 & 0.776 \\
\hline $\mathrm{Na}$ & 0.066 & 0.066 & 0.042 & 0.016 & 0.016 & 0.015 & 0.042 & 0.038 & 0.052 & 0.042 & 0.046 & 0.037 \\
\hline Wo (\%) & 97.993 & 99.041 & 99.121 & 27.941 & 49.028 & 49.291 & 43.197 & 39.194 & 45.215 & 41.992 & 44.446 & 41.043 \\
\hline En (\%) & 0.205 & 0.058 & 0.102 & 54.699 & 41.738 & 41.995 & 32.463 & 33.642 & 32.709 & 33.362 & 33.103 & 36.459 \\
\hline Amostra & M-20_c2_px & M-20_c2_px & प-20_c2_px & $4 \mathrm{M}-20 \_\mathrm{c} 2 \mathrm{px}$ & $5 \mathrm{M}-20 \_\mathrm{c} 2 \mathrm{px} 6$ & $6 \mathrm{M}-20 \_\mathrm{c} 2$-px 1. & 1.M-20_c2_px 1. & $1 . \mathrm{M}-20 \_\mathrm{c} 2 \mathrm{p} \times 1 . \mathrm{I}$ & M-20_c2_px 1.1 & $M-20 \_c 2 \_p \times 6 . N$ & M-20_c2_px 6.N & M-20_c2_px 6. \\
\hline Prof. & 0 & 0 & 0 & 0 & 0 & 0 & 0 & 0 & 0 & 0 & 0 & 0 \\
\hline Rocha & GR & GR & GR & GR & GR & GR & GR & GR & GR & GR & GR & GR \\
\hline $\mathrm{SiO}_{2}(\mathrm{wt} \%)$ & 50.468 & 50.421 & 50.54 & 49.822 & 50.438 & 50.713 & 49.101 & 50.294 & 50.293 & 51.313 & 50.759 & 50.807 \\
\hline $\mathrm{TiO}_{2}(\mathrm{wt} \%)$ & 0.543 & 0.558 & 0.287 & 0.264 & 0.288 & 0.282 & 0.474 & 0.583 & 0.293 & 0.537 & 0.488 & 0.543 \\
\hline $\mathrm{Al}_{2} \mathrm{O}_{3}(\mathrm{wt} \%)$ & 3.175 & 2.989 & 3.725 & 3.751 & 3.184 & 3.239 & 3.386 & 3.521 & 3.677 & 3.119 & 2.929 & 3.273 \\
\hline $\mathrm{Cr}_{2} \mathrm{O}_{3}(\mathrm{wt} \%)$ & 0 & 0 & 0.001 & 0 & 0.013 & 0.038 & 0.049 & 0 & 0.013 & 0.039 & 0 & 0.064 \\
\hline $\mathrm{FeO}(\mathrm{wt} \%)$ & 11.849 & 14.04 & 12.503 & 11.669 & 11.267 & 11.489 & 14.468 & 14.687 & 11.583 & 11.241 & 14.456 & 11.161 \\
\hline $\mathrm{MnO}(\mathrm{wt} \%)$ & 0.187 & 0.314 & 0.288 & 0.317 & 0.27 & 0.186 & 0.334 & 0.546 & 0.147 & 0.338 & 0.381 & 0.306 \\
\hline $\mathrm{MgO}(\mathrm{wt} \%)$ & 12.006 & 12.401 & 12.127 & 11.858 & 11.978 & 11.896 & 12.745 & 12.673 & 11.58 & 12.159 & 12.773 & 11.426 \\
\hline $\mathrm{CaO}(\mathrm{wt} \%)$ & 20.68 & 18.209 & 19.614 & 21.202 & 21.395 & 21.419 & 17.298 & 17.86 & 21.32 & 21.477 & 18.382 & 21.557 \\
\hline $\mathrm{NiO}(\mathrm{wt} \%)$ & 0 & 0.008 & 0.065 & 0.025 & 0.037 & 0.02 & 0.072 & 0 & 0.059 & 0.063 & 0.055 & 0.002 \\
\hline $\mathrm{BaO}(\mathrm{wt} \%)$ & 0 & 0.141 & 0.023 & 0.043 & 0.033 & 0.023 & 0.075 & 0 & 0 & 0.025 & 0 & 0.072 \\
\hline $\mathrm{Na}_{2} \mathrm{O}(\mathrm{wt} \%)$ & 0.462 & 0.459 & 0.628 & 0.557 & 0.536 & 0.562 & 0.503 & 0.441 & 0.611 & 0.542 & 0.385 & 0.566 \\
\hline Total & 99.37 & 99.54 & 99.801 & 99.508 & 99.439 & 99.867 & 98.505 & 100.605 & 99.576 & 100.853 & 100.608 & 99.777 \\
\hline $\mathrm{Si}$ & 1.911 & 1.916 & 1.904 & 1.881 & 1.905 & 1.908 & 1.882 & 1.889 & 1.899 & 1.913 & 1.907 & 1.918 \\
\hline $\mathrm{Ti}$ & 0.015 & 0.016 & 0.008 & 0.007 & 0.008 & 0.008 & 0.014 & 0.016 & 0.008 & 0.015 & 0.014 & 0.015 \\
\hline Al & 0.142 & 0.134 & 0.165 & 0.167 & 0.142 & 0.144 & 0.153 & 0.156 & 0.164 & 0.137 & 0.130 & 0.146 \\
\hline $\mathrm{Cr}$ & 0.000 & 0.000 & 0.000 & 0.000 & 0.000 & 0.001 & 0.001 & 0.000 & 0.000 & 0.001 & 0.000 & 0.002 \\
\hline $\mathrm{Fe}+3$ & 0.039 & 0.036 & 0.055 & 0.097 & 0.070 & 0.064 & 0.092 & 0.066 & 0.067 & 0.045 & 0.057 & 0.027 \\
\hline $\mathrm{Fe}^{+2}$ & 0.336 & 0.410 & 0.338 & 0.272 & 0.286 & 0.297 & 0.371 & 0.396 & 0.299 & 0.305 & 0.397 & 0.326 \\
\hline $\mathrm{Mn}$ & 0.006 & 0.010 & 0.009 & 0.010 & 0.009 & 0.006 & 0.011 & 0.017 & 0.005 & 0.011 & 0.012 & 0.010 \\
\hline $\mathrm{Mg}$ & 0.678 & 0.703 & 0.681 & 0.667 & 0.675 & 0.667 & 0.728 & 0.710 & 0.652 & 0.676 & 0.715 & 0.643 \\
\hline $\mathrm{Ca}$ & 0.839 & 0.741 & 0.792 & 0.858 & 0.866 & 0.863 & 0.710 & 0.719 & 0.862 & 0.858 & 0.740 & 0.872 \\
\hline $\mathrm{Na}$ & 0.034 & 0.034 & 0.046 & 0.041 & 0.039 & 0.041 & 0.037 & 0.032 & 0.045 & 0.039 & 0.028 & 0.041 \\
\hline Wo (\%) & 44.346 & 39.224 & 42.412 & 45.294 & 45.662 & 45.632 & 37.341 & 38.035 & 45.876 & 45.532 & 38.750 & 46.694 \\
\hline En (\%) & 35.822 & 37.169 & 36.486 & 35.248 & 35.569 & 35.263 & 38.281 & 37.552 & 34.670 & 35.867 & 37.464 & 34.436 \\
\hline Amostra & M-20_c2 p $\mathrm{p} 6 . \mathrm{I}$ & $20 \_2 \_p \times 6$ & $20 \_c 2 \_p \times 6.1$ & M-20_c2_px 6. & M-20_c2_px 7DI & $\mathrm{M} 19-\mathrm{cp} \times 5 \mathrm{Dl}$ & $\mathrm{M} 19-\mathrm{cp} \times 6 \mathrm{DN}$ & $\mathrm{M} 19-\mathrm{cp} \times 4 \mathrm{DN}$ & $\mathrm{M} 19-\mathrm{cpx} 1 \mathrm{DN}$ & $\mathrm{M} 19-\mathrm{cp} \times 2 \mathrm{DM}$ & $119-\mathrm{cp} \times 3 \mathrm{DM}$ & $19-\operatorname{cpx} 7$ \\
\hline Prof. & 0 & 0 & 0 & 0 & 0 & 0 & 0 & 0 & 0 & 0 & 0 & 0 \\
\hline Rocha & GR & GR & GR & GR & GR & Grt-cpx gran & Grt-cpx gran & Grt-cpx gran & Grt-cpx gran & Grt-cpx gran & Grt-cpx gran & Grt-cpx gran \\
\hline $\mathrm{SiO}_{2}$ (wt\%) & 50.471 & 50.945 & 50.551 & 50.437 & 50.993 & 45.092 & 45.332 & 44.47 & 47.113 & 46.569 & 45.809 & 45.166 \\
\hline $\mathrm{TiO}_{2}$ (wt\%) & 0.387 & 0.461 & 0.857 & 0.428 & 0.59 & 0.729 & 0.605 & 0.608 & 0.426 & 0.383 & 0.481 & 0.613 \\
\hline $\mathrm{Al}_{2} \mathrm{O}_{3}(\mathrm{wt} \%)$ & 2.945 & 3.349 & 3.22 & 3.266 & 2.907 & 5.734 & 4.71 & 5.942 & 3.659 & 3.544 & 4.742 & 5.504 \\
\hline $\mathrm{Cr}_{2} \mathrm{O}_{3}(\mathrm{wt} \%)$ & 0 & 0 & 0.012 & 0.012 & 0 & 23.39 & 23.098 & 23.865 & 24.468 & 24.575 & 24.607 & 24.223 \\
\hline $\mathrm{FeO}(\mathrm{wt} \%)$ & 15.637 & 11.36 & 12.061 & 11.483 & 12.262 & 0.148 & 0.138 & 0.12 & 0.077 & 0.089 & 0.16 & 0.113 \\
\hline $\mathrm{MnO}(\mathrm{wt} \%)$ & 0.45 & 0.425 & 0.298 & 0.296 & 0.215 & 2.769 & 3.174 & 2.331 & 2.341 & 2.615 & 2.078 & 2.201 \\
\hline $\mathrm{MgO}(\mathrm{wt} \%)$ & 12.871 & 11.815 & 12.011 & 11.985 & 12.399 & 22.203 & 22.209 & 22.103 & 22.035 & 22.211 & 22.04 & 21.955 \\
\hline $\mathrm{CaO}(\mathrm{wt} \%)$ & 17.107 & 21.184 & 20.68 & 21.631 & 20.017 & & & & & & & \\
\hline $\mathrm{NiO}(\mathrm{wt} \%)$ & 0.006 & 0 & 0.035 & 0.053 & 0.055 & & & & & & & \\
\hline $\mathrm{BaO}(\mathrm{wt} \%)$ & 0 & 0.037 & 0.091 & 0 & 0.116 & & & & & & & \\
\hline $\mathrm{Na}_{2} \mathrm{O}(\mathrm{wt} \%)$ & 0.436 & 0.574 & 0.532 & 0.581 & 0.517 & 0.478 & 0.516 & 0.414 & 0.488 & 0.542 & 0.491 & 0.477 \\
\hline Total & 100.31 & 100.15 & 100.348 & 100.172 & 100.071 & 100.577 & 99.782 & 99.853 & 100.607 & 100.531 & 100.447 & 100.252 \\
\hline $\mathrm{Si}$ & 1.904 & 1.913 & 1.900 & 1.892 & 1.920 & 1.787 & 1.808 & 1.780 & 1.879 & 1.855 & 1.829 & 1.803 \\
\hline $\mathrm{Ti}$ & 0.011 & 0.013 & 0.024 & 0.012 & 0.017 & 0.022 & 0.018 & 0.018 & 0.013 & 0.011 & 0.014 & 0.018 \\
\hline Al & 0.131 & 0.148 & 0.143 & 0.144 & 0.129 & 0.268 & 0.221 & 0.280 & 0.172 & 0.166 & 0.223 & 0.259 \\
\hline $\mathrm{Cr}$ & 0.000 & 0.000 & 0.000 & 0.000 & 0.000 & 0.001 & 0.000 & 0.000 & 0.000 & 0.000 & 0.001 & 0.000 \\
\hline $\mathrm{Fe}+3$ & 0.072 & 0.041 & 0.048 & 0.090 & 0.035 & 0.151 & 0.166 & 0.156 & 0.083 & 0.142 & 0.126 & 0.135 \\
\hline $\mathrm{Fe}+2$ & 0.421 & 0.315 & 0.331 & 0.271 & 0.351 & 0.624 & 0.604 & 0.643 & 0.733 & 0.677 & 0.696 & 0.674 \\
\hline $\mathrm{Mn}$ & 0.014 & 0.014 & 0.009 & 0.009 & 0.007 & 0.005 & 0.005 & 0.004 & 0.003 & 0.003 & 0.005 & 0.004 \\
\hline $\mathrm{Mg}$ & 0.724 & 0.661 & 0.673 & 0.670 & 0.696 & 0.164 & 0.189 & 0.139 & 0.139 & 0.155 & 0.124 & 0.131 \\
\hline $\mathrm{Ca}$ & 0.691 & 0.852 & 0.833 & 0.869 & 0.808 & 0.943 & 0.949 & 0.948 & 0.941 & 0.948 & 0.943 & 0.939 \\
\hline $\mathrm{Na}$ & 0.032 & 0.042 & 0.039 & 0.042 & 0.038 & 0.037 & 0.040 & 0.032 & 0.038 & 0.042 & 0.038 & 0.037 \\
\hline Wo (\%) & 36.227 & 45.566 & 44.182 & 45.761 & 42.735 & 50.105 & 49.735 & 50.264 & 49.639 & 49.323 & 49.934 & 49.983 \\
\hline En (\%) & 37.925 & 35.361 & 35.705 & 35.278 & 36.832 & 8.695 & 9.890 & 7.376 & 7.338 & 8.080 & 6.551 & 6.972 \\
\hline
\end{tabular}


PLAGIOCLÁSIO

\begin{tabular}{|c|c|c|c|c|c|c|c|c|c|c|c|c|}
\hline Amostra & M-06B_c2_plg & 06_c4_pl & 1M-06_c4_plg & 2M-06_c4_plg & 3M-06_c4_plg & 4M-06_c4_plg 5 & 5M-06_c4_plg 6 & 6M-06_c4_plg 7I & M-06_c1_plg 1N & M-06_c1_plg & M-06_c1_plg 3M & 1-06_c1_plg \\
\hline Prof. & 220.4 & 220.2 & 220.2 & 220.2 & 220.2 & 220.2 & 220.2 & 220.2 & 220.2 & 220.2 & 220.2 & 220.2 \\
\hline Rocha & Pxt & Xnt & Xnt & Xnt & Xnt & Xnt & Xnt & Xnt & Xnt & Xnt & Xnt & Xnt \\
\hline $\mathrm{SiO}_{2}(\mathrm{wt} \%)$ & 44.430 & 51.760 & 52.474 & 52.184 & 54.264 & 52.961 & 54.444 & 54.111 & 55.257 & 55.204 & 55.408 & 55.638 \\
\hline $\mathrm{Al}_{2} \mathrm{O}_{3}(\mathrm{wt} \%)$ & 35.276 & 30.582 & 29.853 & 30.057 & 28.926 & 29.615 & 28.175 & 28.875 & 28.300 & 28.344 & 28.006 & 27.989 \\
\hline $\mathrm{FeO}(\mathrm{wt} \%)$ & 0.249 & 0.096 & 0.148 & 0.177 & 0.090 & 0.111 & 0.412 & 0.181 & 0.064 & 0.207 & 0.045 & 0.107 \\
\hline $\mathrm{CaO}(\mathrm{wt} \%)$ & 18.729 & 13.487 & 12.277 & 12.555 & 11.288 & 11.990 & 10.565 & 11.296 & 10.384 & 10.484 & 10.312 & 10.111 \\
\hline $\mathrm{Na}_{2} \mathrm{O}(\mathrm{wt} \%)$ & 0.709 & 4.087 & 4.580 & 4.463 & 5.155 & 5.016 & 5.317 & 5.238 & 5.853 & 5.659 & 5.674 & 5.818 \\
\hline $\mathrm{K}_{2} \mathrm{O}(\mathrm{wt} \%)$ & 0.018 & 0.063 & 0.099 & 0.056 & 0.145 & 0.103 & 0.060 & 0.105 & 0.125 & 0.182 & 0.150 & 0.101 \\
\hline Total & 99.411 & 100.075 & 99.431 & 99.492 & 99.868 & 99.796 & 98.973 & 99.806 & 99.983 & 100.080 & 99.595 & 99.764 \\
\hline $\mathrm{Si}$ & 2.001 & 1.968 & 2.001 & 1.988 & 2.054 & 2.014 & 2.068 & 2.052 & 2.087 & 2.085 & 2.097 & 2.102 \\
\hline $\mathrm{Al}$ & 1.342 & 1.371 & 1.342 & 1.349 & 1.291 & 1.327 & 1.261 & 1.291 & 1.260 & 1.262 & 1.249 & 1.246 \\
\hline $\mathrm{Fe}^{+3}$ & 0.870 & 0.868 & 0.870 & 0.869 & 0.864 & 0.867 & 0.866 & 0.865 & 0.862 & 0.862 & 0.864 & 0.862 \\
\hline $\mathrm{Fe}^{+2}$ & 0.005 & 0.003 & 0.005 & 0.006 & 0.003 & 0.004 & 0.013 & 0.006 & 0.002 & 0.007 & 0.001 & 0.003 \\
\hline $\mathrm{Ca}$ & 0.502 & 0.549 & 0.502 & 0.512 & 0.458 & 0.488 & 0.430 & 0.459 & 0.420 & 0.424 & 0.418 & 0.409 \\
\hline $\mathrm{Na}$ & 0.339 & 0.301 & 0.339 & 0.330 & 0.378 & 0.370 & 0.391 & 0.385 & 0.429 & 0.414 & 0.416 & 0.426 \\
\hline $\mathrm{K}$ & 0.005 & 0.003 & 0.005 & 0.003 & 0.007 & 0.005 & 0.003 & 0.005 & 0.006 & 0.009 & 0.007 & 0.005 \\
\hline An (\%) & 59.358 & 64.353 & 59.358 & 60.658 & 54.297 & 56.584 & 52.152 & 54.048 & 49.156 & 50.064 & 49.676 & 48.705 \\
\hline Amostra & M-06_c1_plg 5 & 1-06_c1_plg & 6M-06_c3_plg & 1-06_c3_plg & 1-06_c3_plo & U-06_c3_plg & 4M-06_c3_plg 5 & 5M-06_c2_plg & plg inclus $\mathrm{c} 1$ & 1_plg incluso_c & 1 _plg inclus c1 & 1_plg incluso \\
\hline Prof. & 220.2 & 220.2 & 220.2 & 220.2 & 220.2 & 220.2 & 220.2 & 220.2 & 276.45 & 276.45 & 276.45 & 276.45 \\
\hline Rocha & Xnt & Xnt & Xnt & Xnt & Xnt & Xnt & Xnt & Xnt & Nrt & $\mathrm{Nrt}$ & Nrt & $\mathrm{Nrt}$ \\
\hline $\mathrm{SiO}_{2}(\mathrm{wt} \%)$ & 56.194 & 52.621 & 53.562 & 53.038 & 54.703 & 56.241 & 56.202 & 57.790 & 52.467 & 52.387 & 53.385 & 53.208 \\
\hline $\mathrm{Al}_{2} \mathrm{O}_{3}(\mathrm{wt} \%)$ & 27.931 & 30.026 & 29.407 & 29.886 & 27.589 & 28.121 & 27.718 & 26.476 & 30.502 & 29.788 & 29.976 & 30.276 \\
\hline $\mathrm{FeO}(\mathrm{wt} \%)$ & 0.159 & 0.250 & 0.087 & 0.159 & 0.349 & 0.175 & 0.084 & 0.029 & 0.020 & 0.564 & 0.018 & 0.098 \\
\hline $\mathrm{CaO}(\mathrm{wt} \%)$ & 9.936 & 12.071 & 11.974 & 12.396 & 10.227 & 9.719 & 9.525 & 8.500 & 12.632 & 12.382 & 12.244 & 12.165 \\
\hline $\mathrm{Na}_{2} \mathrm{O}(\mathrm{wt} \%)$ & 5.977 & 4.506 & 4.666 & 4.438 & 5.533 & 5.893 & 6.058 & 6.899 & 4.220 & 4.345 & 4.724 & 4.625 \\
\hline $\mathrm{K}_{2} \mathrm{O}(\mathrm{wt} \%)$ & 0.158 & 0.078 & 0.079 & 0.102 & 0.079 & 0.163 & 0.143 & 0.161 & 0.147 & 0.123 & 0.128 & 0.100 \\
\hline Total & 100.355 & 99.552 & 99.775 & 100.019 & 98.480 & 100.312 & 99.730 & 99.855 & 99.988 & 99.589 & 100.475 & 100.472 \\
\hline $\mathrm{Si}$ & 2.113 & 2.003 & 2.032 & 2.011 & 2.083 & 2.111 & 2.120 & 2.173 & 1.990 & 1.992 & 2.016 & 2.008 \\
\hline $\mathrm{Al}$ & 1.238 & 1.347 & 1.315 & 1.336 & 1.238 & 1.244 & 1.233 & 1.173 & 1.363 & 1.335 & 1.334 & 1.347 \\
\hline $\mathrm{Fe}+3$ & 0.858 & 0.868 & 0.866 & 0.865 & 0.869 & 0.856 & 0.861 & 0.858 & 0.865 & 0.867 & 0.862 & 0.861 \\
\hline $\mathrm{Fe}+2$ & 0.005 & 0.008 & 0.003 & 0.005 & 0.011 & 0.005 & 0.003 & 0.001 & 0.001 & 0.018 & 0.001 & 0.003 \\
\hline $\mathrm{Ca}$ & 0.400 & 0.492 & 0.487 & 0.504 & 0.417 & 0.391 & 0.385 & 0.342 & 0.513 & 0.504 & 0.495 & 0.492 \\
\hline $\mathrm{Na}$ & 0.436 & 0.332 & 0.343 & 0.326 & 0.409 & 0.429 & 0.443 & 0.503 & 0.310 & 0.320 & 0.346 & 0.338 \\
\hline $\mathrm{K}$ & 0.008 & 0.004 & 0.004 & 0.005 & 0.004 & 0.008 & 0.007 & 0.008 & 0.007 & 0.006 & 0.006 & 0.005 \\
\hline An (\%) & 47.449 & 59.410 & 58.376 & 60.325 & 50.296 & 47.232 & 46.108 & 40.139 & 61.789 & 60.722 & 58.458 & 58.900 \\
\hline Amostra & _plg inclu & _plg inclus & -04_c1_plc & -04_c1_plg & 04_c1_pl & 04_c4_plg & 04_c4_plg & 4_plg inclus & _plg inclus & plg inclus & 04_c4_plg 6N & M-04_c4_plg \\
\hline Prof. & 276.45 & 276.45 & 276.45 & 276.45 & 276.45 & 276.45 & 276.45 & 276.45 & 276.45 & 276.45 & 276.45 & 276.45 \\
\hline Rocha & Nrt & Nrt & Nrt & Nrt & Nrt & Nrt & Nrt & Nrt & Nrt & Nrt & $\mathrm{Nrt}$ & $\mathrm{Nrt}$ \\
\hline $\mathrm{SiO}_{2}(\mathrm{wt} \%)$ & 53.003 & 50.717 & 52.057 & 52.036 & 53.248 & 52.594 & 52.182 & 50.766 & 50.882 & 51.214 & 51.934 & 51.260 \\
\hline $\mathrm{Al}_{2} \mathrm{O}_{3}(\mathrm{wt} \%)$ & 29.533 & 31.512 & 30.456 & 30.835 & 30.159 & 30.640 & 30.558 & 31.396 & 31.415 & 31.189 & 31.102 & 31.062 \\
\hline $\mathrm{FeO}(\mathrm{wt} \%)$ & 0.398 & 0.125 & 0.041 & 0.061 & 0.060 & 0.100 & 0.142 & 0.436 & 0.299 & 0.226 & 0.083 & 0.078 \\
\hline $\mathrm{CaO}(\mathrm{wt} \%)$ & 11.845 & 13.928 & 12.947 & 12.956 & 12.218 & 12.797 & 13.055 & 13.721 & 13.898 & 13.963 & 13.473 & 13.400 \\
\hline $\mathrm{Na}_{2} \mathrm{O}(\mathrm{wt} \%)$ & 4.449 & 3.452 & 4.177 & 4.207 & 4.729 & 4.093 & 4.005 & 3.720 & 3.595 & 3.601 & 4.018 & 3.983 \\
\hline $\mathrm{K}_{2} \mathrm{O}(\mathrm{wt} \%)$ & 0.150 & 0.049 & 0.115 & 0.132 & 0.050 & 0.047 & 0.140 & 0.062 & 0.028 & 0.077 & 0.055 & 0.082 \\
\hline Total & 99.378 & 99.783 & 99.793 & 100.227 & 100.464 & 100.271 & 100.082 & 100.101 & 100.117 & 100.270 & 100.665 & 99.865 \\
\hline $\mathrm{Si}$ & 2.018 & 1.933 & 1.981 & 1.972 & 2.011 & 1.990 & 1.981 & 1.930 & 1.936 & 1.947 & 1.962 & 1.953 \\
\hline $\mathrm{Al}$ & 1.325 & 1.416 & 1.366 & 1.377 & 1.342 & 1.366 & 1.367 & 1.407 & 1.408 & 1.397 & 1.385 & 1.394 \\
\hline $\mathrm{Fe}+3$ & 0.869 & 0.870 & 0.868 & 0.865 & 0.862 & 0.863 & 0.866 & 0.867 & 0.868 & 0.867 & 0.862 & 0.869 \\
\hline $\mathrm{Fe}^{+2}$ & 0.013 & 0.004 & 0.001 & 0.002 & 0.002 & 0.003 & 0.005 & 0.014 & 0.010 & 0.007 & 0.003 & 0.002 \\
\hline $\mathrm{Ca}$ & 0.483 & 0.569 & 0.528 & 0.526 & 0.494 & 0.519 & 0.531 & 0.559 & 0.566 & 0.569 & 0.545 & 0.547 \\
\hline $\mathrm{Na}$ & 0.328 & 0.255 & 0.308 & 0.309 & 0.346 & 0.300 & 0.295 & 0.274 & 0.265 & 0.265 & 0.294 & 0.294 \\
\hline $\mathrm{K}$ & 0.007 & 0.002 & 0.006 & 0.006 & 0.002 & 0.002 & 0.007 & 0.003 & 0.001 & 0.004 & 0.003 & 0.004 \\
\hline An (\%) & 59.005 & 68.837 & 62.719 & 62.510 & 58.641 & 63.165 & 63.779 & 66.845 & 68.004 & 67.877 & 64.744 & 64.717 \\
\hline Amostra & M-04_c4_plg 8 & c3_plg inclus & sM-04_c3_plg ( & (rM-04_c3_plg (r & (r) M-04_c3_plg & g 4M-04_c2_plg & 1M-04_c2_plg & -04_c2_plg & 4_c2_plg & _c2_plg (r) & 9_c3_plg & 9_c3_plg \\
\hline Prof. & 276.45 & 276.45 & 276.45 & 276.45 & 276.45 & 276.45 & 276.45 & 276.45 & 276.45 & 276.45 & 209.35 & 209.35 \\
\hline Rocha & $\mathrm{Nrt}$ & $\mathrm{Nrt}$ & $\mathrm{Nrt}$ & Nrt & $\mathrm{Nrt}$ & Nrt & $\mathrm{Nrt}$ & Nrt & $\mathrm{Nrt}$ & $\mathrm{Nrt}$ & Pxt & Pxt \\
\hline $\mathrm{SiO}_{2}(\mathrm{wt} \%)$ & 51.732 & 52.917 & 53.237 & 54.055 & 52.492 & 49.539 & 52.844 & 52.890 & 52.548 & 55.386 & 46.843 & 48.619 \\
\hline $\mathrm{Al}_{2} \mathrm{O}_{3}(\mathrm{wt} \%)$ & 30.444 & 30.074 & 29.724 & 29.208 & 30.185 & 32.323 & 29.657 & 30.037 & 1.967 & 28.632 & 33.872 & 33.041 \\
\hline $\mathrm{FeO}(\mathrm{wt} \%)$ & 0.058 & 0.105 & 0.050 & 0.141 & 0.107 & 0.116 & 0.123 & 0.016 & 20.413 & 0.026 & 0.117 & 0.121 \\
\hline $\mathrm{CaO}(\mathrm{wt} \%)$ & 13.030 & 12.003 & 12.016 & 12.104 & 12.619 & 14.695 & 12.010 & 12.554 & 0.355 & 10.584 & 16.635 & 15.853 \\
\hline $\mathrm{Na}_{2} \mathrm{O}$ (wt $\left.\%\right)$ & 4.105 & 4.422 & 4.744 & 4.786 & 4.282 & 3.106 & 4.615 & 4.543 & 0.000 & 5.663 & 1.906 & 2.413 \\
\hline $\mathrm{K}_{2} \mathrm{O}(\mathrm{wt} \%)$ & 0.033 & 0.168 & 0.193 & 0.175 & 0.064 & 0.021 & 0.072 & 0.058 & 0.016 & 0.070 & 0.063 & 0.069 \\
\hline Total & 99.402 & 99.689 & 99.964 & 100.469 & 99.749 & 99.800 & 99.321 & 100.098 & 75.299 & 100.361 & 99.436 & 100.116 \\
\hline $\mathrm{Si}$ & 1.974 & 2.009 & 2.019 & 2.040 & 1.996 & 1.893 & 2.014 & 2.001 & 2.133 & 2.084 & 1.805 & 1.888 \\
\hline $\mathrm{Al}$ & 1.369 & 1.346 & 1.329 & 1.299 & 1.353 & 1.456 & 1.332 & 1.339 & 0.094 & 1.270 & 1.538 & 1.456 \\
\hline $\mathrm{Fe}^{+3}$ & 0.871 & 0.866 & 0.865 & 0.861 & 0.867 & 0.872 & 0.870 & 0.863 & 0.926 & 0.858 & 0.879 & 0.872 \\
\hline $\mathrm{Fe}^{+2}$ & 0.002 & 0.003 & 0.002 & 0.004 & 0.003 & 0.004 & 0.004 & 0.001 & 0.693 & 0.001 & 0.004 & 0.005 \\
\hline $\mathrm{Ca}$ & 0.533 & 0.488 & 0.488 & 0.490 & 0.514 & 0.602 & 0.490 & 0.509 & 0.015 & 0.427 & 0.687 & 0.613 \\
\hline $\mathrm{Na}$ & 0.304 & 0.326 & 0.349 & 0.350 & 0.316 & 0.230 & 0.341 & 0.333 & 0.000 & 0.413 & 0.142 & 0.223 \\
\hline $\mathrm{K}$ & 0.002 & 0.008 & 0.009 & 0.008 & 0.003 & 0.001 & 0.004 & 0.003 & 0.001 & 0.003 & 0.003 & 0.003 \\
\hline An (\%) & 63.568 & 59.405 & 57.684 & 57.712 & 61.725 & 72.244 & 58.737 & 60.228 & 59.633 & 50.604 & 82.518 & 73.079 \\
\hline
\end{tabular}




\begin{tabular}{|c|c|c|c|c|c|c|c|c|c|c|c|c|}
\hline Amostra & 3_pig & s & 政 & Con & -Cs_t & _c3_plg & 9_c3_pl & M-09_c1_plg & 1 1M-09_c1_plg & 2M-09_c1_plg 3 & 3M-09_c1_plg 4 & 4M-09_c1_p \\
\hline Prof. & 209.35 & 209.35 & 209.35 & 209.35 & 209.35 & 209.35 & 209.35 & 209.35 & 209.35 & 209.35 & 209.35 & 209.35 \\
\hline Rocha & Pxt & Pxt & Pxt & Pxt & Pxt & Pxt & Pxt & Pxt & Pxt & Pxt & Pxt & Pxt \\
\hline $\mathrm{SiO}_{2}(\mathrm{wt} \%)$ & 49.378 & 51.278 & 51.755 & 51.356 & 49.880 & 51.331 & 51.711 & 47.939 & 48.044 & 48.601 & 47.126 & 47.912 \\
\hline $\mathrm{Al}_{2} \mathrm{O}_{3}(\mathrm{wt} \%)$ & 32.321 & 31.170 & 30.795 & 31.129 & 31.649 & 30.841 & 31.011 & 33.083 & 33.335 & 32.615 & 33.683 & 33.185 \\
\hline $\mathrm{FeO}(\mathrm{wt} \%)$ & 0.150 & 0.073 & 0.117 & 0.017 & 0.185 & 0.063 & 0.023 & 0.059 & 0.102 & 0.175 & 0.135 & 0.064 \\
\hline $\mathrm{CaO}(\mathrm{wt} \%)$ & 14.977 & 13.397 & 13.430 & 13.723 & 14.762 & 13.928 & 13.484 & 16.218 & 16.252 & 15.399 & 16.740 & 16.257 \\
\hline $\mathrm{Na}_{2} \mathrm{O}(\mathrm{wt} \%)$ & 3.008 & 3.621 & 3.818 & 3.714 & 2.961 & 3.642 & 3.856 & 2.395 & 2.156 & 2.598 & 1.939 & 2.185 \\
\hline $\mathrm{K}_{2} \mathrm{O}(\mathrm{wt} \%)$ & 0.062 & 0.122 & 0.107 & 0.093 & 0.065 & 0.093 & 0.093 & 0.031 & 0.029 & 0.099 & 0.021 & 0.043 \\
\hline Total & 99.896 & 99.661 & 100.022 & 100.032 & 99.502 & 99.898 & 100.178 & 99.725 & 99.918 & 99.487 & 99.644 & 99.646 \\
\hline $\mathrm{Si}$ & 1.888 & 1.954 & 1.966 & 1.951 & 1.910 & 1.956 & 1.962 & 1.840 & 1.839 & 1.863 & 1.812 & 1.839 \\
\hline Al & 1.456 & 1.400 & 1.379 & 1.394 & 1.428 & 1.385 & 1.387 & 1.497 & 1.503 & 1.473 & 1.526 & 1.502 \\
\hline $\mathrm{Fe}+3$ & 0.872 & 0.869 & 0.867 & 0.867 & 0.874 & 0.869 & 0.866 & 0.876 & 0.873 & 0.874 & 0.877 & 0.876 \\
\hline $\mathrm{Fe}^{+2}$ & 0.005 & 0.002 & 0.004 & 0.001 & 0.006 & 0.002 & 0.001 & 0.002 & 0.003 & 0.006 & 0.004 & 0.002 \\
\hline $\mathrm{Ca}$ & 0.613 & 0.547 & 0.547 & 0.559 & 0.606 & 0.569 & 0.548 & 0.667 & 0.666 & 0.632 & 0.690 & 0.669 \\
\hline $\mathrm{Na}$ & 0.223 & 0.268 & 0.281 & 0.274 & 0.220 & 0.269 & 0.284 & 0.178 & 0.160 & 0.193 & 0.145 & 0.163 \\
\hline $\mathrm{K}$ & 0.003 & 0.006 & 0.005 & 0.005 & 0.003 & 0.005 & 0.005 & 0.002 & 0.001 & 0.005 & 0.001 & 0.002 \\
\hline An (\%) & 73.079 & 66.669 & 65.619 & 66.763 & 73.088 & 67.515 & 65.543 & 78.770 & 80.503 & 76.164 & 82.569 & 80.233 \\
\hline Amostra & M-09_c1_plg $191-$ & 09_c2_plg (rM & -09_c2_plg (IMM & -09_c2_plg(n) & 9_c2_plg (IN & 09 -c2_plg (r) N & 1-09_c2_plg 6 & 6M-10_c3_plg 11 & 1M-10_c3_plg 2N & M-10_c3_plg 3M & 1-10_c3_plg 4M & M-10_c3_plg 5 \\
\hline Prof. & 209.35 & 209.35 & 209.35 & 209.35 & 209.35 & 209.35 & 209.35 & 209.45 & 209.45 & 209.45 & 209.45 & 209.45 \\
\hline Rocha & Pxt & Pxt & Pxt & Pxt & Pxt & Pxt & Pxt & Pxt & Pxt & Pxt & Pxt & Pxt \\
\hline $\mathrm{SiO}_{2}(\mathrm{wt} \%)$ & 46.967 & 53.430 & 53.112 & 53.735 & 53.816 & 53.054 & 50.104 & 44.739 & 44.605 & 44.786 & 43.997 & 44.398 \\
\hline $\mathrm{Al}_{2} \mathrm{O}_{3}(\mathrm{wt} \%)$ & 33.568 & 29.453 & 28.957 & 29.033 & 28.999 & 29.924 & 31.581 & 34.924 & 35.581 & 35.216 & 35.682 & 35.447 \\
\hline $\mathrm{FeO}(\mathrm{wt} \%)$ & 0.085 & 0.065 & 0.383 & 0.059 & 0.062 & 0.057 & 0.108 & 0.247 & 0.171 & 0.138 & 0.242 & 0.162 \\
\hline $\mathrm{CaO}(\mathrm{wt} \%)$ & 16.605 & 12.061 & 11.784 & 11.843 & 11.406 & 11.962 & 14.272 & 18.779 & 18.571 & 18.659 & 19.223 & 18.683 \\
\hline $\mathrm{Na}_{2} \mathrm{O}(\mathrm{wt} \%)$ & 2.008 & 4.528 & 4.907 & 4.607 & 4.901 & 4.850 & 3.334 & 0.836 & 0.650 & 0.860 & 0.573 & 0.815 \\
\hline $\mathrm{K}_{2} \mathrm{O}(\mathrm{wt} \%)$ & 0.012 & 0.181 & 0.167 & 0.256 & 0.200 & 0.153 & 0.052 & 0.000 & 0.024 & 0.019 & 0.000 & 0.000 \\
\hline Total & 99.245 & 99.718 & 99.310 & 99.533 & 99.384 & 100.000 & 99.451 & 99.525 & 99.602 & 99.678 & 99.717 & 99.505 \\
\hline $\mathrm{Si}$ & 1.811 & 2.028 & 2.018 & 2.043 & 2.047 & 2.011 & 1.917 & 1.731 & 1.722 & 1.730 & 1.702 & 1.718 \\
\hline Al & 1.525 & 1.317 & 1.297 & 1.301 & 1.300 & 1.337 & 1.424 & 1.592 & 1.619 & 1.604 & 1.627 & 1.616 \\
\hline $\mathrm{Fe}^{+3}$ & 0.880 & 0.866 & 0.867 & 0.868 & 0.868 & 0.865 & 0.873 & 0.883 & 0.881 & 0.882 & 0.883 & 0.883 \\
\hline $\mathrm{Fe}^{+2}$ & 0.003 & 0.002 & 0.012 & 0.002 & 0.002 & 0.002 & 0.003 & 0.008 & 0.006 & 0.004 & 0.008 & 0.005 \\
\hline $\mathrm{Ca}$ & 0.686 & 0.490 & 0.480 & 0.482 & 0.465 & 0.486 & 0.585 & 0.778 & 0.768 & 0.772 & 0.797 & 0.775 \\
\hline $\mathrm{Na}$ & 0.150 & 0.333 & 0.361 & 0.340 & 0.362 & 0.356 & 0.247 & 0.063 & 0.049 & 0.064 & 0.043 & 0.061 \\
\hline $\mathrm{K}$ & 0.001 & 0.009 & 0.008 & 0.012 & 0.010 & 0.007 & 0.003 & 0.000 & 0.001 & 0.001 & 0.000 & 0.000 \\
\hline An (\%) & 81.988 & 58.919 & 56.484 & 57.814 & 55.603 & 57.177 & 70.073 & 92.545 & 93.908 & 92.198 & 94.882 & 92.684 \\
\hline Amostra & M-10_c3_plg 6N & $\mid-18$-c1_plg 7 & M-18_c1_plg 1 & A-18_c1_plg & 18_c1_plg & 18_c1_plg & 1-18_c1_p & 6M-20_c2_plg $1 !$ & 1M-20_c2_plg 2l & 2M-20_c2_plg 3N & M-20_c2_plg 4M & M-20_c2_plg \\
\hline Prof. & 209.45 & 0 & 0 & 0 & 0 & 0 & 0 & 0 & 0 & 0 & 0 & 0 \\
\hline Rocha & Pxt & GR & GR & GR & GR & GR & GR & GR & GR & GR & GR & GR \\
\hline $\mathrm{SiO}_{2}(\mathrm{wt} \%)$ & 44.947 & 59.596 & 59.135 & 59.733 & 59.821 & 59.705 & 59.393 & 55.468 & 55.863 & 55.180 & 56.040 & 56.014 \\
\hline $\mathrm{Al}_{2} \mathrm{O}_{3}(\mathrm{wt} \%)$ & 35.572 & 25.402 & 25.477 & 25.382 & 25.203 & 25.478 & 25.601 & 28.020 & 27.866 & 28.088 & 27.916 & 28.145 \\
\hline $\mathrm{FeO}(w t \%)$ & 0.159 & 0.145 & 0.101 & 0.083 & 0.074 & 0.157 & 0.077 & 0.110 & 0.146 & 0.058 & 0.127 & 0.157 \\
\hline $\mathrm{CaO}(\mathrm{wt} \%)$ & 18.526 & 7.132 & 7.399 & 7.089 & 6.817 & 6.982 & 7.207 & 10.205 & 10.201 & 9.885 & 10.219 & 9.920 \\
\hline $\mathrm{Na}_{2} \mathrm{O}(\mathrm{wt} \%)$ & 0.911 & 7.930 & 7.696 & 7.400 & 7.535 & 7.517 & 7.606 & 5.569 & 5.566 & 5.895 & 5.821 & 5.965 \\
\hline $\mathrm{K}_{2} \mathrm{O}$ (wt\%) & 0.014 & 0.233 & 0.221 & 0.343 & 0.315 & 0.287 & 0.303 & 0.291 & 0.312 & 0.306 & 0.313 & 0.293 \\
\hline Total & 100.129 & 100.438 & 100.029 & 100.030 & 99.765 & 100.126 & 100.187 & 99.663 & 99.954 & 99.412 & 100.436 & 100.494 \\
\hline $\mathrm{Si}$ & 1.728 & 2.228 & 2.219 & 2.235 & 2.242 & 2.232 & 2.224 & 2.100 & 2.106 & 2.094 & 2.109 & 2.106 \\
\hline $\mathrm{Al}$ & 1.612 & 1.119 & 1.127 & 1.120 & 1.113 & 1.123 & 1.130 & 1.250 & 1.238 & 1.256 & 1.238 & 1.247 \\
\hline $\mathrm{Fe}+3$ & 0.877 & 0.853 & 0.856 & 0.854 & 0.855 & 0.853 & 0.854 & 0.864 & 0.860 & 0.866 & 0.859 & 0.858 \\
\hline $\mathrm{Fe}^{+2}$ & 0.005 & 0.005 & 0.003 & 0.003 & 0.002 & 0.005 & 0.002 & 0.003 & 0.005 & 0.002 & 0.004 & 0.005 \\
\hline $\mathrm{Ca}$ & 0.763 & 0.286 & 0.297 & 0.284 & 0.274 & 0.280 & 0.289 & 0.414 & 0.412 & 0.402 & 0.412 & 0.400 \\
\hline $\mathrm{Na}$ & 0.068 & 0.575 & 0.560 & 0.537 & 0.548 & 0.545 & 0.552 & 0.409 & 0.407 & 0.434 & 0.425 & 0.435 \\
\hline $\mathrm{K}$ & 0.001 & 0.011 & 0.011 & 0.016 & 0.015 & 0.014 & 0.014 & 0.014 & 0.015 & 0.015 & 0.015 & 0.014 \\
\hline An (\%) & 91.753 & 32.776 & 34.272 & 33.937 & 32.731 & 33.364 & 33.785 & 49.468 & 49.412 & 47.258 & 48.373 & 47.096 \\
\hline Amostra & -20_c2_plg 6N & 1-20_c1_plg 1 & M-20_c1_plg & 20_c1_plg 4 & -20_c1_plg & 0_c1_plg & 20_c1_plg 7 & 6_c4_plg & 6_c4_plg & 6_c4_plg & 6_c4_plg 4 & 06_c4_plg \\
\hline Prof. & 0 & 0 & 0 & 0 & 0 & 0 & 0 & 220.2 & 220.2 & 220.2 & 220.2 & 220.2 \\
\hline Rocha & GR & GR & GR & GR & GR & GR & GR & Xnt & Xnt & Xnt & Xnt & Xnt \\
\hline $\mathrm{SiO}_{2}(\mathrm{wt} \%)$ & 55.994 & 56.103 & 55.540 & 55.727 & 55.966 & 56.355 & 55.571 & 51.760 & 52.474 & 52.184 & 54.264 & 52.961 \\
\hline $\mathrm{Al}_{2} \mathrm{O}_{3}(\mathrm{wt} \%)$ & 28.230 & 28.109 & 28.370 & 28.272 & 28.091 & 27.613 & 28.251 & 30.582 & 29.853 & 30.057 & 28.926 & 29.615 \\
\hline $\mathrm{FeO}(\mathrm{wt} \%)$ & 0.060 & 0.076 & 0.056 & 0.053 & 0.054 & 0.134 & 0.145 & 0.096 & 0.148 & 0.177 & 0.090 & 0.111 \\
\hline $\mathrm{CaO}(\mathrm{wt} \%)$ & 10.405 & 10.118 & 10.464 & 10.308 & 9.969 & 9.965 & 10.130 & 13.487 & 12.277 & 12.555 & 11.288 & 11.990 \\
\hline $\mathrm{Na}_{2} \mathrm{O}(\mathrm{wt} \%)$ & 5.687 & 5.956 & 5.847 & 5.878 & 5.829 & 5.958 & 6.040 & 4.087 & 4.580 & 4.463 & 5.155 & 5.016 \\
\hline $\mathrm{K}_{2} \mathrm{O}$ (wt\%) & 0.304 & 0.241 & 0.260 & 0.264 & 0.337 & 0.323 & 0.336 & 0.063 & 0.099 & 0.056 & 0.145 & 0.103 \\
\hline Total & 100.680 & 100.603 & 100.537 & 100.502 & 100.246 & 100.348 & 100.473 & 100.075 & 99.431 & 99.492 & 99.868 & 99.796 \\
\hline $\mathrm{Si}$ & 2.102 & 2.105 & 2.088 & 2.094 & 2.106 & 2.120 & 2.090 & 1.968 & 2.001 & 1.988 & 2.054 & 2.014 \\
\hline Al & 1.249 & 1.243 & 1.257 & 1.252 & 1.246 & 1.224 & 1.252 & 1.371 & 1.342 & 1.349 & 1.291 & 1.327 \\
\hline $\mathrm{Fe}^{+3}$ & 0.856 & 0.856 & 0.858 & 0.857 & 0.859 & 0.858 & 0.858 & 0.868 & 0.870 & 0.869 & 0.864 & 0.867 \\
\hline $\mathrm{Fe}^{+2}$ & 0.002 & 0.002 & 0.002 & 0.002 & 0.002 & 0.004 & 0.005 & 0.003 & 0.005 & 0.006 & 0.003 & 0.004 \\
\hline $\mathrm{Ca}$ & 0.418 & 0.407 & 0.422 & 0.415 & 0.402 & 0.402 & 0.408 & 0.549 & 0.502 & 0.512 & 0.458 & 0.488 \\
\hline $\mathrm{Na}$ & 0.414 & 0.433 & 0.426 & 0.428 & 0.425 & 0.435 & 0.440 & 0.301 & 0.339 & 0.330 & 0.378 & 0.370 \\
\hline K & 0.015 & 0.012 & 0.012 & 0.013 & 0.016 & 0.016 & 0.016 & 0.003 & 0.005 & 0.003 & 0.007 & 0.005 \\
\hline An (\%) & 49.410 & 47.764 & 49.001 & 48.487 & 47.656 & 47.157 & 47.204 & 64.353 & 59.358 & 60.658 & 54.297 & 56.584 \\
\hline
\end{tabular}




\begin{tabular}{|c|c|c|c|c|c|c|c|c|c|c|c|c|}
\hline Amostra & \multicolumn{12}{|c|}{ M-06_c4_plg 6M-06_c4_plg 7M-06_c1_plg 1M-06_c1_plg 2M-06_c1_plg 3M-06_c1_plg 4M-06_c1_plg 5M-06_c1_plg 6M-06_c3_plg 1M-06_c3_plg 2M-06_c3_plg 3M-06_c3_plg } \\
\hline Prof. & 220.2 & 220.2 & 220.2 & 220.2 & 220.2 & 220.2 & 220.2 & 220.2 & 220.2 & 220.2 & 220.2 & 220.2 \\
\hline Rocha & Xnt & Xnt & Xnt & Xnt & Xnt & Xnt & Xnt & Xnt & Xnt & Xnt & Xnt & Xnt \\
\hline $\mathrm{SiO}_{2}(\mathrm{wt} \%)$ & 54.444 & 54.111 & 55.257 & 55.204 & 55.408 & 55.638 & 56.194 & 52.621 & 53.562 & 53.038 & 54.703 & 56.241 \\
\hline $\mathrm{Al}_{2} \mathrm{O}_{3}(\mathrm{wt} \%)$ & 28.175 & 28.875 & 28.300 & 28.344 & 28.006 & 27.989 & 27.931 & 30.026 & 29.407 & 29.886 & 27.589 & 28.121 \\
\hline $\mathrm{FeO}(w t \%)$ & 0.412 & 0.181 & 0.064 & 0.207 & 0.045 & 0.107 & 0.159 & 0.250 & 0.087 & 0.159 & 0.349 & 0.175 \\
\hline $\mathrm{CaO}(w t \%)$ & 10.565 & 11.296 & 10.384 & 10.484 & 10.312 & 10.111 & 9.936 & 12.071 & 11.974 & 12.396 & 10.227 & 9.719 \\
\hline $\mathrm{Na}_{2} \mathrm{O}(w t \%)$ & 5.317 & 5.238 & 5.853 & 5.659 & 5.674 & 5.818 & 5.977 & 4.506 & 4.666 & 4.438 & 5.533 & 5.893 \\
\hline $\mathrm{K}_{2} \mathrm{O}(\mathrm{wt} \%)$ & 0.060 & 0.105 & 0.125 & 0.182 & 0.150 & 0.101 & 0.158 & 0.078 & 0.079 & 0.102 & 0.079 & 0.163 \\
\hline Total & 98.973 & 99.806 & 99.983 & 100.080 & 99.595 & 99.764 & 100.355 & 99.552 & 99.775 & 100.019 & 98.480 & 100.312 \\
\hline $\mathrm{Si}$ & 2.068 & 2.052 & 2.087 & 2.085 & 2.097 & 2.102 & 2.113 & 2.003 & 2.032 & 2.011 & 2.083 & 2.111 \\
\hline Al & 1.261 & 1.291 & 1.260 & 1.262 & 1.249 & 1.246 & 1.238 & 1.347 & 1.315 & 1.336 & 1.238 & 1.244 \\
\hline $\mathrm{Fe}^{+3}$ & 0.866 & 0.865 & 0.862 & 0.862 & 0.864 & 0.862 & 0.858 & 0.868 & 0.866 & 0.865 & 0.869 & 0.856 \\
\hline $\mathrm{Fe}^{+2}$ & 0.013 & 0.006 & 0.002 & 0.007 & 0.001 & 0.003 & 0.005 & 0.008 & 0.003 & 0.005 & 0.011 & 0.005 \\
\hline $\mathrm{Ca}$ & 0.430 & 0.459 & 0.420 & 0.424 & 0.418 & 0.409 & 0.400 & 0.492 & 0.487 & 0.504 & 0.417 & 0.391 \\
\hline $\mathrm{Na}$ & 0.391 & 0.385 & 0.429 & 0.414 & 0.416 & 0.426 & 0.436 & 0.332 & 0.343 & 0.326 & 0.409 & 0.429 \\
\hline $\mathrm{K}$ & 0.003 & 0.005 & 0.006 & 0.009 & 0.007 & 0.005 & 0.008 & 0.004 & 0.004 & 0.005 & 0.004 & 0.008 \\
\hline An (\%) & 52.152 & 54.048 & 49.156 & 50.064 & 49.676 & 48.705 & 47.449 & 59.410 & 58.376 & 60.325 & 50.296 & 47.232 \\
\hline Amostra & \multicolumn{2}{|c|}{ M-06_c3_plg 5M-06_c2_plg } & DM $19-$ plg8 & DM $19-$ plg9 & DM $19-$ plg12 & $\mathrm{DM} 19-\mathrm{plg} 13$ & DM $19-$ plg14 & DM $19-$ plg15 & DM $19-$ plg10 & DM $19-$ plg11 & DM $19-$ plg1 & DM $19-$ plg2 \\
\hline Prof. & $220 . \overline{2}$ & 220.2 & 0 & 0 & 0 & 0 & 0 & 0 & 0 & 0 & 0 & 0 \\
\hline Rocha & Xnt & Xnt & Grt-cpx gran & Grt-cpx gran & Grt-cpx gran & Grt-cpx gran & Grt-cpx gran & Grt-cpx gran & Grt-cpx gran & Grt-cpx gran & Grt-cpx gran & Grt-cpx gran \\
\hline $\mathrm{SiO}_{2}(\mathrm{wt} \%)$ & 56.202 & 57.790 & 45.817 & 45.692 & 45.519 & 45.705 & 45.419 & 45.516 & 46.283 & 46.077 & 47.295 & 46.962 \\
\hline $\mathrm{Al}_{2} \mathrm{O}_{3}(\mathrm{wt} \%)$ & 27.718 & 26.476 & 35.608 & 35.264 & 35.148 & 35.405 & 35.247 & 35.42 & 35.078 & 35.42 & 34.987 & 34.674 \\
\hline $\mathrm{FeO}(w t \%)$ & 0.084 & 0.029 & 0.229 & 0.118 & 0.262 & 0.145 & 0.258 & 0.174 & 0.259 & 0.125 & 0.344 & 0.338 \\
\hline $\mathrm{CaO}(w t \%)$ & 9.525 & 8.500 & 18.883 & 18.562 & 18.432 & 18.428 & 18.399 & 18.664 & 18.376 & 18.674 & 17.841 & 18.089 \\
\hline $\mathrm{Na}_{2} \mathrm{O}(\mathrm{wt} \%)$ & 6.058 & 6.899 & 0.793 & 0.948 & 0.796 & 0.88 & 0.825 & 0.819 & 0.907 & 0.875 & 1.337 & 1.295 \\
\hline $\mathrm{K}_{2} \mathrm{O}(\mathrm{wt} \%)$ & 0.143 & 0.161 & 0.017 & 0.025 & 0.073 & 0.02 & 0.024 & 0.013 & 0.053 & 0.046 & 0.053 & 0.055 \\
\hline Total & 99.730 & 99.855 & 101.347 & 100.609 & 100.253 & 100.631 & 100.348 & 100.606 & 101.135 & 101.221 & 101.901 & 101.413 \\
\hline $\mathrm{Si}$ & 2.120 & 2.173 & 2.087 & 2.094 & 2.097 & 2.096 & 2.091 & 2.088 & 2.115 & 2.100 & 2.137 & 2.133 \\
\hline Al & 1.233 & 1.173 & 1.912 & 1.905 & 1.908 & 1.913 & 1.912 & 1.915 & 1.889 & 1.903 & 1.863 & 1.856 \\
\hline $\mathrm{Fe}^{+3}$ & 0.861 & 0.858 & 0.000 & 0.000 & 0.000 & 0.000 & 0.000 & 0.000 & 0.000 & 0.000 & 0.000 & 0.000 \\
\hline $\mathrm{Fe}^{+2}$ & 0.003 & 0.001 & 0.009 & 0.005 & 0.010 & 0.006 & 0.010 & 0.007 & 0.010 & 0.005 & 0.013 & 0.013 \\
\hline $\mathrm{Ca}$ & 0.385 & 0.342 & 0.922 & 0.911 & 0.910 & 0.905 & 0.908 & 0.917 & 0.900 & 0.912 & 0.864 & 0.880 \\
\hline $\mathrm{Na}$ & 0.443 & 0.503 & 0.070 & 0.084 & 0.071 & 0.078 & 0.074 & 0.073 & 0.080 & 0.077 & 0.117 & 0.114 \\
\hline $\mathrm{K}$ & 0.007 & 0.008 & 0.001 & 0.001 & 0.004 & 0.001 & 0.001 & 0.001 & 0.003 & 0.003 & 0.003 & 0.003 \\
\hline An (\%) & 46.108 & 40.139 & 92.845 & 91.406 & 92.348 & 91.936 & 92.362 & 92.572 & 91.512 & 91.935 & 87.785 & 88.248 \\
\hline Amostra & DM $19-$ plg3 & DM $19-$ plg4 & DM $19-$ plg5 & DM 19 - plg6 & DM 19 - plg7 & & & & & & & \\
\hline Prof. & 0 & 0 & 0 & 0 & 0 & & & & & & & \\
\hline Rocha & Grt-cpx gran & Grt-cpx gran & Grt-cpx gran & Grt-cpx gran & Grt-cpx gran & & & & & & & \\
\hline $\mathrm{SiO}_{2}(\mathrm{wt} \%)$ & 47.251 & 46.702 & 46.329 & 46.418 & 46.649 & & & & & & & \\
\hline $\mathrm{Al}_{2} \mathrm{O}_{3}(\mathrm{wt} \%)$ & 34.701 & 34.437 & 34.761 & 34.482 & 34.575 & & & & & & & \\
\hline $\mathrm{FeO}(w t \%)$ & 0.353 & 0.224 & 0.391 & 0.307 & 0.326 & & & & & & & \\
\hline $\mathrm{CaO}(w t \%)$ & 17.242 & 17.296 & 18.036 & 17.791 & 17.585 & & & & & & & \\
\hline $\mathrm{Na}_{2} \mathrm{O}(\mathrm{wt} \%)$ & 1.507 & 1.48 & 1.143 & 1.384 & 1.399 & & & & & & & \\
\hline $\mathrm{K}_{2} \mathrm{O}(\mathrm{wt} \%)$ & 0.099 & 0.048 & 0.054 & 0.049 & 0.06 & & & & & & & \\
\hline Total & 101.154 & 100.187 & 100.768 & 100.518 & 100.618 & & & & & & & \\
\hline $\mathrm{Si}$ & 2.148 & 2.144 & 2.120 & 2.126 & 2.133 & & & & & & & \\
\hline $\mathrm{Al}$ & 1.860 & 1.863 & 1.875 & 1.861 & 1.863 & & & & & & & \\
\hline $\mathrm{Fe}+3$ & 0.000 & 0.000 & 0.000 & 0.000 & 0.000 & & & & & & & \\
\hline $\mathrm{Fe}+2$ & 0.013 & 0.009 & 0.015 & 0.012 & 0.012 & & & & & & & \\
\hline $\mathrm{Ca}$ & 0.840 & 0.851 & 0.884 & 0.873 & 0.862 & & & & & & & \\
\hline $\mathrm{Na}$ & 0.133 & 0.132 & 0.101 & 0.123 & 0.124 & & & & & & & \\
\hline $\mathrm{K}$ & 0.006 & 0.003 & 0.003 & 0.003 & 0.004 & & & & & & & \\
\hline An (\%) & 85.837 & 86.344 & 89.426 & 87.408 & 87.106 & & & & & & & \\
\hline
\end{tabular}


HIALOFANA

\begin{tabular}{|c|c|c|c|c|c|c|c|c|c|c|}
\hline \multicolumn{11}{|l|}{ Amostra } \\
\hline Prof. & $220 . \overline{2}$ & 0 & 0 & $\overline{0}$ & $\overline{0}$ & $2 \overline{20} . \overline{2}$ & $220 . \overline{2}$ & $220 . \overline{2}$ & $220 . \overline{2}$ & $220 . \overline{2}$ \\
\hline Rocha & Xnt & GR & GR & GR & GR & Xnt & Xnt & Xnt & Xnt & Xnt \\
\hline $\mathrm{SiO}_{2}(\mathrm{wt} \%)$ & 60.361 & 62.329 & 63.831 & 63.979 & 63.788 & 62.796 & 59.725 & 60.562 & 60.483 & 59.676 \\
\hline $\mathrm{TiO}_{2}(\mathrm{wt} \%)$ & 0.084 & 0.235 & 0.09 & 0.055 & 0.131 & 0 & 0.06 & 0 & 0 & 0 \\
\hline $\mathrm{Al}_{2} \mathrm{O}_{3}$ (wt\%) & 19.716 & 20.909 & 18.981 & 18.769 & 18.803 & 18.66 & 19.381 & 19.507 & 19.753 & 19.416 \\
\hline $\mathrm{FeO}(\mathrm{wt} \%)$ & 0.076 & 0.034 & 0.021 & 0.062 & 0.08 & 0.066 & 0.059 & 0.098 & 0.084 & 0.052 \\
\hline $\mathrm{MnO}(\mathrm{wt} \%)$ & 0.025 & 0 & 0 & 0 & 0 & 0.038 & 0.018 & 0 & 0.088 & 0.027 \\
\hline $\mathrm{MgO}(\mathrm{wt} \%)$ & 0.018 & 0 & 0 & 0.001 & 0.013 & 0.01 & 0.018 & 0 & 0.037 & 0 \\
\hline $\mathrm{CaO}$ (wt\%) & 0.002 & 2.536 & 0.216 & 0.154 & 0.313 & 0.055 & 0.055 & 0 & 0.006 & 0.027 \\
\hline $\mathrm{Na}_{2} \mathrm{O}(\mathrm{wt} \%)$ & 1.182 & 3.362 & 1.292 & 1.223 & 1.495 & 1.062 & 1.045 & 1.107 & 1.12 & 1.209 \\
\hline $\mathrm{K}_{2} \mathrm{O}(\mathrm{wt} \%)$ & 12.589 & 9.611 & 14.248 & 14.12 & 14.196 & 13.972 & 12.676 & 12.779 & 12.585 & 12.799 \\
\hline $\mathrm{BaO}$ (wt\%) & 6.212 & 0.554 & 0.887 & 0.961 & 0.671 & 2.743 & 6.11 & 5.804 & 5.725 & 5.841 \\
\hline Total & 100.265 & 99.57 & 99.566 & 99.324 & 99.49 & 99.402 & 99.147 & 99.857 & 99.881 & 99.047 \\
\hline $\mathrm{Si}$ & 2.886 & 2.861 & 2.967 & 2.986 & 2.960 & 2.965 & 2.889 & 2.902 & 2.896 & 2.878 \\
\hline $\mathrm{Al}$ & 1.111 & 1.131 & 1.040 & 1.032 & 1.028 & 1.038 & 1.105 & 1.101 & 1.114 & 1.104 \\
\hline $\mathrm{Fe}^{+3}$ & 0.000 & 0.000 & 0.000 & 0.000 & 0.003 & 0.000 & 0.000 & 0.000 & 0.000 & 0.002 \\
\hline $\mathrm{Ti}$ & 0.003 & 0.008 & 0.003 & 0.002 & 0.005 & 0.000 & 0.002 & 0.000 & 0.000 & 0.000 \\
\hline $\mathrm{Mg}$ & 0.001 & 0.000 & 0.000 & 0.000 & 0.001 & 0.001 & 0.001 & 0.000 & 0.003 & 0.000 \\
\hline $\mathrm{Fe}^{+2}$ & 0.003 & 0.001 & 0.001 & 0.002 & 0.000 & 0.003 & 0.002 & 0.004 & 0.003 & 0.000 \\
\hline $\mathrm{Mn}$ & 0.001 & 0.000 & 0.000 & 0.000 & 0.000 & 0.002 & 0.001 & 0.000 & 0.004 & 0.001 \\
\hline $\mathrm{Ca}$ & 0.000 & 0.125 & 0.011 & 0.008 & 0.016 & 0.003 & 0.003 & 0.000 & 0.000 & 0.001 \\
\hline $\mathrm{Na}$ & 0.110 & 0.299 & 0.116 & 0.111 & 0.135 & 0.097 & 0.098 & 0.103 & 0.104 & 0.113 \\
\hline $\mathrm{K}$ & 0.768 & 0.563 & 0.845 & 0.841 & 0.840 & 0.841 & 0.782 & 0.781 & 0.769 & 0.787 \\
\hline $\mathrm{Ba}$ & 0.116 & 0.010 & 0.016 & 0.018 & 0.012 & 0.051 & 0.116 & 0.109 & 0.107 & 0.110 \\
\hline$\%$ Or & 77.256 & 56.467 & 85.494 & 86.081 & 83.816 & 84.809 & 78.309 & 78.668 & 78.408 & 77.790 \\
\hline \multicolumn{11}{|c|}{ Amostra DM-06 c2 kf 7DM-06 c2 kf 8DM-06 c2 kf 9 M-06 c2 kf 10M-06 c2 kf 11M-06 c2 kf 12M-06 c2 kf 13M-06 c2 kf 14M-06 c2 kf 15} \\
\hline Prof. & 220.2 & 220.2 & 220.2 & 220.2 & $220 . \overline{2}$ & 220.2 & 220.2 & 220.2 & 220.2 & \\
\hline Rocha & Xnt & Xnt & Xnt & Xnt & Xnt & Xnt & Xnt & Xnt & Xnt & \\
\hline $\mathrm{SiO}_{2}(\mathrm{wt} \%)$ & 60.021 & 60.164 & 63.011 & 60.171 & 60.4 & 63.439 & 59.434 & 63.076 & 59.715 & \\
\hline $\mathrm{TiO}_{2}(w t \%)$ & 0 & 0.154 & 0.049 & 0 & 0 & 0.06 & 0 & 0 & 0.089 & \\
\hline $\mathrm{Al}_{2} \mathrm{O}_{3}(\mathrm{wt} \%)$ & 19.716 & 19.677 & 18.868 & 19.781 & 19.301 & 18.919 & 19.755 & 19.004 & 19.446 & \\
\hline $\mathrm{FeO}(\mathrm{wt} \%)$ & 0.002 & 0.062 & 0.052 & 0 & 0.073 & 0.082 & 0.076 & 0.04 & 0.172 & \\
\hline $\mathrm{MnO}(\mathrm{wt} \%)$ & 0.004 & 0 & 0 & 0.021 & 0.033 & 0 & 0.008 & 0.007 & 0.01 & \\
\hline $\mathrm{MgO}$ (wt\%) & 0 & 0 & 0.041 & 0.021 & 0.037 & 0 & 0 & 0.015 & 0.055 & \\
\hline $\mathrm{CaO}(\mathrm{wt} \%)$ & 0.1 & 0.066 & 0.018 & 0.023 & 0.007 & 0.034 & 0.008 & 0.016 & 0.039 & \\
\hline $\mathrm{Na}_{2} \mathrm{O}$ (wt\%) & 1.198 & 1.147 & 0.99 & 0.893 & 1.183 & 0.997 & 1.007 & 0.922 & 1.028 & \\
\hline $\mathrm{K}_{2} \mathrm{O}(\mathrm{wt} \%)$ & 12.334 & 12.49 & 14.071 & 12.576 & 12.819 & 14.091 & 12.62 & 14.593 & 12.682 & \\
\hline $\mathrm{BaO}(\mathrm{wt} \%)$ & 6.217 & 6.134 & 3.098 & 6.346 & 4.911 & 2.574 & 6.665 & 2.739 & 6.096 & \\
\hline Total & 99.592 & 99.894 & 100.198 & 99.832 & 98.764 & 100.196 & 99.573 & 100.412 & 99.332 & \\
\hline $\mathrm{Si}$ & 2.889 & 2.888 & 2.958 & 2.897 & 2.907 & 2.969 & 2.871 & 2.947 & 2.884 & \\
\hline $\mathrm{Al}$ & 1.119 & 1.113 & 1.044 & 1.123 & 1.095 & 1.043 & 1.125 & 1.046 & 1.107 & \\
\hline $\mathrm{Fe}^{+3}$ & 0.000 & 0.000 & 0.000 & 0.000 & 0.000 & 0.000 & 0.003 & 0.002 & 0.000 & \\
\hline $\mathrm{Ti}$ & 0.000 & 0.006 & 0.002 & 0.000 & 0.000 & 0.002 & 0.000 & 0.000 & 0.003 & \\
\hline $\mathrm{Mg}$ & 0.000 & 0.000 & 0.003 & 0.002 & 0.003 & 0.000 & 0.000 & 0.001 & 0.004 & \\
\hline $\mathrm{Fe}^{+2}$ & 0.000 & 0.002 & 0.002 & 0.000 & 0.003 & 0.003 & 0.000 & 0.000 & 0.007 & \\
\hline $\mathrm{Mn}$ & 0.000 & 0.000 & 0.000 & 0.001 & 0.001 & 0.000 & 0.000 & 0.000 & 0.000 & \\
\hline $\mathrm{Ca}$ & 0.005 & 0.003 & 0.001 & 0.001 & 0.000 & 0.002 & 0.000 & 0.001 & 0.002 & \\
\hline $\mathrm{Na}$ & 0.112 & 0.107 & 0.090 & 0.083 & 0.110 & 0.090 & 0.094 & 0.084 & 0.096 & \\
\hline $\mathrm{K}$ & 0.757 & 0.765 & 0.843 & 0.772 & 0.787 & 0.841 & 0.778 & 0.870 & 0.781 & \\
\hline $\mathrm{Ba}$ & 0.117 & 0.115 & 0.057 & 0.120 & 0.093 & 0.047 & 0.126 & 0.050 & 0.115 & \\
\hline$\%$ Or & 76.379 & 77.229 & 85.061 & 79.086 & 79.467 & 85.788 & 77.880 & 86.610 & 78.528 & \\
\hline
\end{tabular}




\section{GRANADA}

\begin{tabular}{|c|c|c|c|c|c|c|c|c|c|c|c|c|c|c|}
\hline Amostra & grt7 & grt8 & grt9 & grt10 & grt11 & grt12 & grt13 & grt14 & grt15 & grt16 & grt17 & grt18 & grt19 & grt20 \\
\hline Prof. & 0 & 0 & 0 & 0 & 0 & 0 & 0 & 0 & 0 & 0 & 0 & 0 & 0 & 0 \\
\hline Rocha & Grt-hed-gran & Grt-hed-gran & Grt-hed-gran & Grt-hed-gran & Grt-hed-gran & Grt-hed-gran & Grt-hed-gran & Grt-hed-gran & Grt-hed-gran & Grt-hed-gran & Grt-hed-gran & Grt-hed-gran & Grt-hed-gran & Grt-hed-gran \\
\hline $\mathrm{SiO}_{2}(\mathrm{wt} \%)$ & 37.207 & 37.101 & 37.715 & 37.715 & 39.486 & 37.643 & 37.247 & 37.788 & 36.58 & 38.165 & 37.805 & 28.482 & 37.691 & 37.852 \\
\hline $\mathrm{TiO}_{2}$ (wt\%) & 0.84 & 0.706 & 0.684 & 0.621 & 0.741 & 0.647 & 0.832 & 0.822 & 0.871 & 0.661 & 0.674 & 0.429 & 0.613 & 0.603 \\
\hline $\mathrm{Al}_{2} \mathrm{O}_{3}(\mathrm{wt} \%)$ & 10.146 & 11.094 & 11.963 & 11.546 & 11.914 & 11.229 & 10.097 & 10.198 & 9.829 & 11.802 & 11.437 & 8.856 & 11.58 & 12.098 \\
\hline $\mathrm{Cr}_{2} \mathrm{O}_{3}$ (wt\%) & 0 & 0 & 0.024 & 0.016 & 0 & 0 & 0 & 0.041 & 0.026 & 0 & 0.003 & 0.05 & 0 & 0 \\
\hline $\mathrm{FeO}(\mathrm{wt} \%)$ & 21.048 & 19.627 & 18.79 & 19.557 & 19.449 & 20.004 & 20.517 & 20.973 & 20.863 & 19.057 & 19.254 & 12.503 & 19.013 & 19.198 \\
\hline $\mathrm{MnO}(\mathrm{wt} \%)$ & 0.409 & 0.439 & 0.418 & 0.386 & 0.401 & 0.437 & 0.384 & 0.364 & 0.442 & 0.416 & 0.411 & 0.262 & 0.365 & 0.454 \\
\hline $\mathrm{MgO}$ (wt\%) & 0.064 & 0.099 & 0.094 & 0.081 & 0.081 & 0.045 & 0.084 & 0.081 & 0.074 & 0.06 & 0.047 & 0.041 & 0.09 & 0.067 \\
\hline $\mathrm{CaO}(w t \%)$ & 30.057 & 29.962 & 29.877 & 30.43 & 29.297 & 29.522 & 29.945 & 30.169 & 29.735 & 30.136 & 30.556 & 22.905 & 30.653 & 30.353 \\
\hline Total & 99.771 & 99.028 & 99.565 & 100.352 & 101.369 & 99.527 & 99.106 & 100.436 & 98.42 & 100.297 & 100.187 & 73.528 & 100.005 & 100.625 \\
\hline $\mathrm{Si}$ & 2.975 & 2.976 & 3.000 & 2.981 & 3.091 & 3.007 & 2.996 & 3.001 & 2.967 & 3.016 & 2.993 & 3.056 & 2.986 & 2.980 \\
\hline $\mathrm{Ti}$ & 0.051 & 0.043 & 0.041 & 0.037 & 0.044 & 0.039 & 0.050 & 0.049 & 0.053 & 0.039 & 0.040 & 0.035 & 0.037 & 0.036 \\
\hline $\mathrm{Al}$ & 0.956 & 1.049 & 1.122 & 1.076 & 1.099 & 1.057 & 0.957 & 0.954 & 0.940 & 1.099 & 1.067 & 1.120 & 1.081 & 1.122 \\
\hline $\mathrm{Cr}$ & 0.000 & 0.000 & 0.002 & 0.001 & 0.000 & 0.000 & 0.000 & 0.003 & 0.002 & 0.000 & 0.000 & 0.004 & 0.000 & 0.000 \\
\hline $\mathrm{Fe}_{+3}$ & 0.992 & 0.915 & 0.795 & 0.887 & 0.632 & 0.852 & 0.951 & 0.944 & 1.018 & 0.791 & 0.867 & 0.695 & 0.874 & 0.847 \\
\hline $\mathrm{Fe}^{+2}$ & 0.415 & 0.402 & 0.455 & 0.406 & 0.641 & 0.484 & 0.429 & 0.449 & 0.397 & 0.469 & 0.408 & 0.427 & 0.386 & 0.417 \\
\hline $\mathrm{Mn}$ & 0.028 & 0.030 & 0.028 & 0.026 & 0.027 & 0.030 & 0.026 & 0.024 & 0.030 & 0.028 & 0.028 & 0.024 & 0.024 & 0.030 \\
\hline $\mathrm{Mg}$ & 0.008 & 0.012 & 0.011 & 0.010 & 0.009 & 0.005 & 0.010 & 0.010 & 0.009 & 0.007 & 0.006 & 0.007 & 0.011 & 0.008 \\
\hline $\mathrm{Ca}$ & 2.575 & 2.575 & 2.546 & 2.577 & 2.457 & 2.526 & 2.580 & 2.567 & 2.584 & 2.551 & 2.592 & 2.633 & 2.602 & 2.560 \\
\hline$\%$ almandine & 13.725 & 13.315 & 14.974 & 13.439 & 20.462 & 15.898 & 14.096 & 14.720 & 13.138 & 15.344 & 13.457 & 13.820 & 12.756 & 13.837 \\
\hline \% pyrope & 0.252 & 0.392 & 0.367 & 0.316 & 0.302 & 0.176 & 0.331 & 0.314 & 0.296 & 0.231 & 0.183 & 0.212 & 0.352 & 0.261 \\
\hline$\%$ grossular & 40.711 & 44.598 & 47.948 & 45.906 & 48.552 & 45.016 & 41.409 & 41.194 & 39.941 & 47.585 & 46.194 & 51.476 & 46.727 & 47.533 \\
\hline$\%$ spessartine & 0.916 & 0.988 & 0.926 & 0.856 & 0.848 & 0.971 & 0.859 & 0.803 & 1.005 & 0.911 & 0.909 & 0.770 & 0.810 & 1.004 \\
\hline$\%$ andradite & 42.246 & 38.895 & 33.971 & 37.865 & 27.909 & 36.284 & 41.128 & 40.738 & 43.291 & 34.228 & 37.513 & 31.935 & 37.777 & 35.853 \\
\hline$\% \mathrm{Ca}-\mathrm{Ti} \mathrm{Gt}$ & 2.151 & 1.811 & 1.749 & 1.575 & 1.927 & 1.655 & 2.177 & 2.119 & 2.258 & 1.701 & 1.737 & 1.591 & 1.578 & 1.512 \\
\hline Amostra & grt21 & grt23 & grt24 & grt25 & grt22 & grt1 & grt2 & grt3 & grt4 & grt5 & grt6 & grt26 & grt27 & \\
\hline Prof. & 0 & 0 & 0 & 0 & 0 & 0 & 0 & 0 & 0 & 0 & 0 & 0 & 0 & \\
\hline Rocha & Grt-hed-gran & Grt-hed-gran & Grt-hed-gran & Grt-hed-gran & Grt-hed-gran & Grt-hed-gran & Grt-hed-gran & Grt-hed-gran & Grt-hed-gran & Grt-hed-gran & Grt-hed-gran & Grt-hed-gran & Grt-hed-gran & \\
\hline $\mathrm{SiO}_{2}(\mathrm{wt} \%)$ & 38.009 & 38.022 & 37.6 & 38.202 & 37.266 & 37.597 & 38.873 & 37.939 & 37.529 & 38.107 & 37.286 & 37.199 & 37.606 & \\
\hline $\mathrm{TiO}_{2}(\mathrm{wt} \%)$ & 0.578 & 0.517 & 0.363 & 0.46 & 0.944 & 0.429 & 0.109 & 0.341 & 0.547 & 0.362 & 0.656 & 1.123 & 0.77 & \\
\hline $\mathrm{Al}_{2} \mathrm{O}_{3}$ (wt\%) & 11.756 & 13.402 & 14.556 & 13.655 & 10.036 & 11.491 & 17.979 & 14.424 & 12.116 & 13.951 & 9.872 & 9.951 & 12.365 & \\
\hline $\mathrm{Cr}_{2} \mathrm{O}_{3}(\mathrm{wt} \%)$ & 0.009 & 0.033 & 0 & 0.021 & 0.037 & 0.031 & 0.019 & 0 & 0 & 0 & 0 & 0.005 & 0.007 & \\
\hline $\mathrm{FeO}(w t \%)$ & 19.552 & 20.735 & 20.076 & 20.576 & 21.826 & 21.572 & 18.921 & 20.004 & 21.647 & 20.387 & 22.435 & 21.148 & 18.895 & \\
\hline $\mathrm{MnO}(\mathrm{wt} \%)$ & 0.392 & 0.315 & 0.36 & 0.288 & 0.392 & 0.404 & 0.449 & 0.465 & 0.357 & 0.452 & 0.435 & 0.42 & 0.382 & \\
\hline $\mathrm{MgO}(\mathrm{wt} \%)$ & 0.084 & 0.154 & 0.144 & 0.171 & 0.078 & 0.11 & 0.151 & 0.11 & 0.071 & 0.133 & 0.05 & 0.084 & 0.128 & \\
\hline $\mathrm{CaO}(\mathrm{wt} \%)$ & 29.927 & 27.689 & 26.663 & 26.751 & 29.13 & 28.368 & 23.553 & 26.799 & 27.671 & 27.045 & 28.685 & 29.858 & 29.844 & \\
\hline Total & 100.307 & 100.867 & 99.762 & 100.124 & 99.709 & 100.002 & 100.054 & 100.082 & 99.938 & 100.437 & 99.419 & 99.788 & 99.997 & \\
\hline $\mathrm{Si}$ & 3.005 & 2.990 & 2.981 & 3.025 & 2.989 & 2.995 & 3.054 & 2.999 & 2.991 & 3.006 & 3.002 & 2.978 & 2.977 & \\
\hline $\mathrm{Ti}$ & 0.034 & 0.031 & 0.022 & 0.027 & 0.057 & 0.026 & 0.006 & 0.020 & 0.033 & 0.021 & 0.040 & 0.068 & 0.046 & \\
\hline $\mathrm{Al}$ & 1.096 & 1.242 & 1.360 & 1.274 & 0.949 & 1.079 & 1.665 & 1.344 & 1.138 & 1.297 & 0.937 & 0.939 & 1.154 & \\
\hline $\mathrm{Cr}$ & 0.001 & 0.002 & 0.000 & 0.001 & 0.002 & 0.002 & 0.001 & 0.000 & 0.000 & 0.000 & 0.000 & 0.000 & 0.000 & \\
\hline $\mathrm{Fe}+3$ & 0.825 & 0.715 & 0.635 & 0.619 & 0.957 & 0.878 & 0.213 & 0.617 & 0.814 & 0.649 & 0.979 & 0.970 & 0.800 & \\
\hline $\mathrm{Fe}^{+2}$ & 0.468 & 0.649 & 0.697 & 0.743 & 0.507 & 0.559 & 1.030 & 0.706 & 0.628 & 0.696 & 0.532 & 0.446 & 0.451 & \\
\hline $\mathrm{Mn}$ & 0.026 & 0.021 & 0.024 & 0.019 & 0.027 & 0.027 & 0.030 & 0.031 & 0.024 & 0.030 & 0.030 & 0.028 & 0.026 & \\
\hline $\mathrm{Mg}$ & 0.010 & 0.018 & 0.017 & 0.020 & 0.009 & 0.013 & 0.018 & 0.013 & 0.008 & 0.016 & 0.006 & 0.010 & 0.015 & \\
\hline $\mathrm{Ca}$ & 2.535 & 2.333 & 2.265 & 2.270 & 2.503 & 2.421 & 1.983 & 2.270 & 2.363 & 2.285 & 2.475 & 2.561 & 2.531 & \\
\hline$\%$ almandine & 15.405 & 21.473 & 23.199 & 24.353 & 16.635 & 18.512 & 33.666 & 23.366 & 20.783 & 22.986 & 17.477 & 14.647 & 14.915 & \\
\hline \% pyrope & 0.326 & 0.598 & 0.567 & 0.661 & 0.306 & 0.432 & 0.578 & 0.429 & 0.279 & 0.517 & 0.197 & 0.329 & 0.500 & \\
\hline$\%$ grossular & 46.737 & 48.214 & 50.882 & 49.291 & 39.673 & 43.576 & 57.205 & 50.994 & 44.796 & 49.771 & 38.971 & 39.943 & 48.303 & \\
\hline$\%$ spessartine & 0.864 & 0.695 & 0.805 & 0.633 & 0.874 & 0.902 & 0.976 & 1.031 & 0.797 & 0.998 & 0.975 & 0.935 & 0.847 & \\
\hline$\%$ andradite & 35.179 & 27.754 & 23.737 & 23.951 & 40.033 & 35.461 & 7.313 & 23.411 & 32.055 & 24.905 & 40.727 & 41.256 & 33.498 & \\
\hline$\% \mathrm{Ca}-\mathrm{Ti} \mathrm{Gt}$ & 1.466 & 1.187 & 0.810 & 1.060 & 2.381 & 1.038 & 0.221 & 0.769 & 1.290 & 0.824 & 1.652 & 2.876 & 1.919 & \\
\hline
\end{tabular}


BIOTITA

\begin{tabular}{|c|c|c|c|c|c|c|c|c|c|c|c|c|}
\hline Amostra & DM-13_c3_bt & DM-13_c3_b & bt DM-13_c3_bt & DM-13_c3_bt & DM-13_c3_bt & DM-04_c1_bt & DM-04_c1_bt & DM-04_c1_bt & DM-04_c1_bt & DM-09_c3_bt & DM-09_c3_bt & DM-09_c3_bt \\
\hline Prof. & $14 \overline{9} .6$ & $14 \overline{9} .6$ & $1 \overline{49} . \overline{6}$ & $14 \overline{9} .6$ & $14 \overline{9} .6$ & 276.45 & 276.45 & 276.45 & 276.45 & 209.35 & 209.35 & 209.35 \\
\hline Rocha & $\mathrm{Hzb}$ & $\mathrm{Hzb}$ & $\mathrm{Hzb}$ & $\mathrm{Hzb}$ & $\mathrm{Hzb}$ & Nrt & Nrt & Nrt & Nrt & Pxt & Pxt & Pxt \\
\hline $\mathrm{SiO} 2$ & 37.392 & 37.741 & 38.509 & 38.093 & 37.84 & 39.018 & 38.871 & 38.272 & 38.707 & 38.847 & 38.194 & 38.886 \\
\hline $\mathrm{TiO} 2$ & 2.733 & 1.935 & 1.415 & 0.787 & 1.764 & 3.308 & 3.066 & 3.965 & 3.342 & 3.879 & 3.974 & 2.837 \\
\hline $\mathrm{Al} 2 \mathrm{O} 3$ & 16.318 & 16.464 & 15.872 & 16.309 & 16.43 & 16.111 & 16.42 & 16.071 & 16.215 & 15.552 & 15.439 & 15.624 \\
\hline $\mathrm{FeO}$ & 4.927 & 5.006 & 4.665 & 4.412 & 4.804 & 9.62 & 9.814 & 10.615 & 10.714 & 10.353 & 10.516 & 9.706 \\
\hline $\mathrm{MnO}$ & 0 & 0 & 0.129 & 0 & 0 & 0.09 & 0.02 & 0 & 0 & 0.171 & 0 & 0.022 \\
\hline $\mathrm{MgO}$ & 22.605 & 23.003 & 23.784 & 23.575 & 22.826 & 18.158 & 18.03 & 16.887 & 17.445 & 17.438 & 17.868 & 18.395 \\
\hline $\mathrm{CaO}$ & 0.021 & 0.002 & 0.015 & 0.039 & 0 & 0.036 & 0.049 & 0.061 & 0.045 & 0.061 & 0.062 & 0.039 \\
\hline $\mathrm{Na} 2 \mathrm{O}$ & 0.625 & 0.704 & 0.772 & 0.647 & 0.655 & 0.14 & 0.118 & 0.098 & 0.075 & 0.078 & 0.095 & 0.138 \\
\hline K2O & 9.115 & 9.234 & 9.318 & 9.12 & 9.465 & 9.66 & 9.633 & 9.766 & 9.647 & 9.548 & 9.42 & 9.217 \\
\hline $\mathrm{BaO}$ & 0.362 & 0.306 & 0.426 & 0.472 & 0.342 & 0.176 & 0.252 & 0.454 & 0.384 & 0.582 & 0.544 & 0.388 \\
\hline $\mathrm{F}$ & 0.275 & 0.281 & 0.21 & 0.28 & 0.321 & 0.232 & 0.342 & 0.203 & 0.198 & 0.469 & 0.305 & 0.407 \\
\hline $\mathrm{Cl}$ & 0.015 & 0.023 & 0.032 & 0.03 & 0.045 & 0.012 & 0.014 & 0.049 & 0.011 & 0.025 & 0.03 & 0.023 \\
\hline $\mathrm{Cr} 2 \mathrm{O} 3$ & 0.382 & 0.353 & 0.262 & 0.369 & 0.329 & 0.18 & 0.218 & 0.205 & 0.116 & 0 & 0.078 & 0.041 \\
\hline $\mathrm{NiO}$ & 0.09 & 0.1 & 0.052 & 0.213 & 0.079 & 0 & 0.045 & 0.093 & 0.058 & 0.121 & 0.06 & 0.097 \\
\hline $\mathrm{H} 2 \mathrm{O}^{*}$ & 5.261 & 4.973 & 4.631 & 5.779 & 5.245 & 3.358 & 3.256 & 3.36 & 3.128 & 3.076 & 3.547 & 4.356 \\
\hline Total & 100.121 & 100.125 & 100.092 & 100.125 & 100.145 & 100.099 & 100.148 & 100.099 & 100.085 & 100.2 & 100.132 & 100.176 \\
\hline $\mathrm{Si}$ & 5.388 & 5.421 & 5.505 & 5.502 & 5.452 & 5.599 & 5.582 & 5.545 & 5.577 & 5.609 & 5.542 & 5.645 \\
\hline Al iv & 2.612 & 2.579 & 2.495 & 2.498 & 2.548 & 2.401 & 2.418 & 2.455 & 2.423 & 2.391 & 2.458 & 2.355 \\
\hline Al vi & 0.160 & 0.208 & 0.179 & 0.279 & 0.243 & 0.324 & 0.362 & 0.289 & 0.331 & 0.255 & 0.183 & 0.318 \\
\hline $\mathrm{Ti}$ & 0.296 & 0.209 & 0.152 & 0.085 & 0.191 & 0.357 & 0.331 & 0.432 & 0.362 & 0.421 & 0.434 & 0.310 \\
\hline $\mathrm{Fe}$ & 0.594 & 0.601 & 0.558 & 0.533 & 0.579 & 1.155 & 1.179 & 1.286 & 1.291 & 1.250 & 1.276 & 1.178 \\
\hline $\mathrm{Mn}$ & 0.000 & 0.000 & 0.016 & 0.000 & 0.000 & 0.011 & 0.002 & 0.000 & 0.000 & 0.021 & 0.000 & 0.003 \\
\hline $\mathrm{Mg}$ & 4.856 & 4.925 & 5.068 & 5.076 & 4.903 & 3.884 & 3.860 & 3.647 & 3.747 & 3.753 & 3.865 & 3.981 \\
\hline $\mathrm{Ca}$ & 0.003 & 0.000 & 0.002 & 0.006 & 0.000 & 0.006 & 0.008 & 0.009 & 0.007 & 0.009 & 0.010 & 0.006 \\
\hline $\mathrm{Na}$ & 0.175 & 0.196 & 0.214 & 0.181 & 0.183 & 0.039 & 0.033 & 0.028 & 0.021 & 0.022 & 0.027 & 0.039 \\
\hline $\mathrm{K}$ & 1.675 & 1.692 & 1.699 & 1.680 & 1.740 & 1.768 & 1.765 & 1.805 & 1.773 & 1.758 & 1.744 & 1.707 \\
\hline $\mathrm{Ba}$ & 0.020 & 0.017 & 0.024 & 0.027 & 0.019 & 0.010 & 0.014 & 0.026 & 0.022 & 0.033 & 0.031 & 0.022 \\
\hline $\mathrm{F}$ & 0.125 & 0.128 & 0.095 & 0.128 & 0.146 & 0.105 & 0.155 & 0.093 & 0.090 & 0.214 & 0.140 & 0.187 \\
\hline $\mathrm{Cl}$ & 0.004 & 0.006 & 0.008 & 0.007 & 0.011 & 0.003 & 0.003 & 0.012 & 0.003 & 0.006 & 0.007 & 0.006 \\
\hline $\mathrm{Cr}$ & 0.044 & 0.040 & 0.030 & 0.042 & 0.037 & 0.020 & 0.025 & 0.023 & 0.013 & 0.000 & 0.009 & 0.005 \\
\hline $\mathrm{Ni}$ & 0.010 & 0.012 & 0.006 & 0.025 & 0.009 & 0.000 & 0.005 & 0.011 & 0.007 & 0.014 & 0.007 & 0.011 \\
\hline $\mathrm{OH}^{*}$ & 3.871 & 3.867 & 3.897 & 3.865 & 3.843 & 3.892 & 3.841 & 3.895 & 3.907 & 3.780 & 3.853 & 3.807 \\
\hline $\mathrm{Fe} / \mathrm{Fe}+\mathrm{Mg}$ & 0.109 & 0.109 & 0.099 & 0.095 & 0.106 & 0.229 & 0.234 & 0.261 & 0.256 & 0.250 & 0.248 & 0.228 \\
\hline Amostra & DM-09_c3_bt & DM-09_c1_b & bt (DM-09_c1_bt & DM-09_c1_bt & DM-09_c1_bt & DM-09_c1_bt & DM-09_c1_bt & DM-09_c1_bt & DM-09_c2_bt & DM-09_c2_bt & DM-09_c2_bt & DM-09_c2_bt \\
\hline Prof. & 209.35 & 209.35 & 209.35 & 209.35 & 209.35 & 209.35 & 209.35 & 209.35 & 209.35 & 209.35 & 209.35 & 209.35 \\
\hline Rocha & Pxt & Pxt & Pxt & Pxt & Pxt & Pxt & Pxt & Pxt & Pxt & Pxt & Pxt & Pxt \\
\hline $\mathrm{SiO} 2$ & 38.23 & 39.199 & 38.955 & 38.656 & 38.543 & 39.677 & 39.308 & 39.58 & 38.615 & 37.928 & 36.269 & 38.104 \\
\hline $\mathrm{TiO} 2$ & 3.738 & 2.476 & 2.97 & 2.539 & 3.854 & 2.884 & 3.494 & 2.806 & 3.111 & 3.705 & 4.023 & 3.848 \\
\hline $\mathrm{Al} 2 \mathrm{O} 3$ & 15.285 & 16.448 & 15.973 & 15.931 & 16.321 & 15.424 & 16.252 & 16.201 & 15.897 & 15.371 & 14.324 & 15.85 \\
\hline $\mathrm{FeO}$ & 10.312 & 8.269 & 9.045 & 8.972 & 8.77 & 8.631 & 8.06 & 8.073 & 9.99 & 11.015 & 10.837 & 10.482 \\
\hline $\mathrm{MnO}$ & 0.029 & 0 & 0.082 & 0.001 & 0 & 0.038 & 0.01 & 0.004 & 0.103 & 0.018 & 0 & 0.074 \\
\hline $\mathrm{MgO}$ & 17.186 & 19.679 & 18.552 & 18.883 & 18.474 & 19.837 & 19.628 & 20.043 & 17.644 & 17.211 & 17.246 & 17.211 \\
\hline $\mathrm{CaO}$ & 0.023 & 0.009 & 0.023 & 0.083 & 0.003 & 0.038 & 0.048 & 0.022 & 0 & 0.093 & 0.089 & 0.158 \\
\hline $\mathrm{Na} 2 \mathrm{O}$ & 0.122 & 0.136 & 0.182 & 0.189 & 0.189 & 0.173 & 0.217 & 0.162 & 0.079 & 0.073 & 0.059 & 0.078 \\
\hline $\mathrm{K} 2 \mathrm{O}$ & 9.566 & 9.002 & 9.323 & 9.032 & 9.067 & 8.605 & 8.971 & 9.09 & 9.716 & 9.717 & 9.146 & 9.541 \\
\hline $\mathrm{BaO}$ & 0.384 & 0.35 & 0.432 & 0.378 & 0.4 & 0.254 & 0.517 & 0.419 & 0.233 & 0.438 & 0.504 & 0.63 \\
\hline $\mathrm{F}$ & 0.211 & 0.432 & 0.415 & 0.39 & 0.289 & 0.261 & 0.384 & 0.355 & 0.347 & 0.345 & 0.303 & 0.21 \\
\hline $\mathrm{Cl}$ & 0 & 0.02 & 0.035 & 0.032 & 0.011 & 0.013 & 0.004 & 0 & 0.009 & 0 & 0.035 & 0.028 \\
\hline $\mathrm{Cr} 2 \mathrm{O} 3$ & 0.205 & 0.132 & 0.129 & 0.142 & 0.074 & 0.143 & 0.269 & 0.182 & 0.039 & 0.077 & 0.039 & 0.052 \\
\hline $\mathrm{NiO}$ & 0.112 & 0.116 & 0.087 & 0.046 & 0.101 & 0.05 & 0.027 & 0.072 & 0.157 & 0.14 & 0.067 & 0.138 \\
\hline $\mathrm{H} 2 \mathrm{O}^{*}$ & 4.687 & 3.92 & 3.981 & 4.899 & 4.028 & 4.083 & 2.975 & 3.141 & 4.209 & 4.014 & 7.194 & 3.692 \\
\hline Total & 100.09 & 100.188 & 100.184 & 100.173 & 100.124 & 100.111 & 100.164 & 100.15 & 100.149 & 100.145 & 100.135 & 100.096 \\
\hline $\mathrm{Si}$ & 5.603 & 5.610 & 5.622 & 5.619 & 5.545 & 5.676 & 5.574 & 5.615 & 5.615 & 5.554 & 5.504 & 5.542 \\
\hline Al iv & 2.397 & 2.390 & 2.378 & 2.381 & 2.455 & 2.324 & 2.426 & 2.385 & 2.385 & 2.446 & 2.496 & 2.458 \\
\hline Al vi & 0.244 & 0.385 & 0.339 & 0.349 & 0.313 & 0.277 & 0.291 & 0.324 & 0.340 & 0.207 & 0.066 & 0.260 \\
\hline $\mathrm{Ti}$ & 0.412 & 0.266 & 0.322 & 0.278 & 0.417 & 0.310 & 0.373 & 0.299 & 0.340 & 0.408 & 0.459 & 0.421 \\
\hline $\mathrm{Fe}$ & 1.264 & 0.990 & 1.092 & 1.091 & 1.055 & 1.033 & 0.956 & 0.958 & 1.215 & 1.349 & 1.375 & 1.275 \\
\hline $\mathrm{Mn}$ & 0.004 & 0.000 & 0.010 & 0.000 & 0.000 & 0.005 & 0.001 & 0.000 & 0.013 & 0.002 & 0.000 & 0.009 \\
\hline $\mathrm{Mg}$ & 3.755 & 4.198 & 3.991 & 4.092 & 3.962 & 4.230 & 4.149 & 4.239 & 3.825 & 3.757 & 3.901 & 3.732 \\
\hline $\mathrm{Ca}$ & 0.004 & 0.001 & 0.004 & 0.013 & 0.000 & 0.006 & 0.007 & 0.003 & 0.000 & 0.015 & 0.014 & 0.025 \\
\hline $\mathrm{Na}$ & 0.035 & 0.038 & 0.051 & 0.053 & 0.053 & 0.048 & 0.060 & 0.045 & 0.022 & 0.021 & 0.017 & 0.022 \\
\hline $\mathrm{K}$ & 1.788 & 1.643 & 1.716 & 1.675 & 1.664 & 1.570 & 1.623 & 1.645 & 1.802 & 1.815 & 1.770 & 1.770 \\
\hline $\mathrm{Ba}$ & 0.022 & 0.020 & 0.024 & 0.022 & 0.023 & 0.014 & 0.029 & 0.023 & 0.013 & 0.025 & 0.030 & 0.036 \\
\hline $\mathrm{F}$ & 0.098 & 0.196 & 0.189 & 0.179 & 0.132 & 0.118 & 0.172 & 0.159 & 0.160 & 0.160 & 0.145 & 0.097 \\
\hline $\mathrm{Cl}$ & 0.000 & 0.005 & 0.009 & 0.008 & 0.003 & 0.003 & 0.001 & 0.000 & 0.002 & 0.000 & 0.009 & 0.007 \\
\hline $\mathrm{Cr}$ & 0.024 & 0.015 & 0.015 & 0.016 & 0.008 & 0.016 & 0.030 & 0.020 & 0.004 & 0.009 & 0.005 & 0.006 \\
\hline $\mathrm{Ni}$ & 0.013 & 0.013 & 0.010 & 0.005 & 0.012 & 0.006 & 0.003 & 0.008 & 0.018 & 0.016 & 0.008 & 0.016 \\
\hline $\mathrm{OH}^{*}$ & 3.902 & 3.800 & 3.802 & 3.813 & 3.866 & 3.879 & 3.827 & 3.841 & 3.838 & 3.840 & 3.846 & 3.896 \\
\hline $\mathrm{Fe} / \mathrm{Fe}+\mathrm{Mg}$ & 0.252 & 0.191 & 0.215 & 0.210 & 0.210 & 0.196 & 0.187 & 0.184 & 0.241 & 0.264 & 0.261 & 0.255 \\
\hline
\end{tabular}




\begin{tabular}{|c|c|c|c|c|c|c|c|c|c|c|c|c|c|c|}
\hline Amostra & DM-09_c2_bt & DM-09_c2_bt & DM-09_c2_bt & DM-18_c1_bt & DM-18_c1_bt & DM-18_c1_bt & t DM-18_c1_bt & DM-18_c1_bt & DM-18_c1_bt & DM-04_c4_bt & DM-04_c4_bt & DM-04_c4_bt & DM-04_c4_bt D & DM-10_c2_bt \\
\hline Prof. & 209.35 & 209.35 & 209.35 & 0 & 0 & 0 & 0 & 0 & 0 & 276.45 & 276.45 & 276.45 & 276.45 & 209.45 \\
\hline Rocha & Pxt & Pxt & Pxt & GR & GR & GR & GR & GR & GR & Nrt & Nrt & $\mathrm{Nrt}$ & $\mathrm{Nrt}$ & Pxt \\
\hline $\mathrm{SiO} 2$ & 38.29 & 38.713 & 38.196 & 36.196 & 36.838 & 36.505 & 36.155 & 36.593 & 36.218 & 38.954 & 38.84 & 38.098 & 37.874 & 38.036 \\
\hline TiO2 & 4.326 & 3.252 & 3.732 & 4.979 & 5.276 & 5.17 & 5.204 & 5.134 & 5.703 & 2.876 & 2.603 & 2.329 & 2.513 & 2.208 \\
\hline $\mathrm{Al} 2 \mathrm{O} 3$ & 15.408 & 14.036 & 15.76 & 13.905 & 13.791 & 13.919 & 14.009 & 13.825 & 14.084 & 16.357 & 16.523 & 15.935 & 16.585 & 16.563 \\
\hline $\mathrm{FeO}$ & 9.706 & 10.398 & 10.398 & 19.603 & 19.701 & 20.175 & 19.571 & 19.149 & 20.379 & 10.629 & 9.629 & 10.877 & 10.819 & 9.438 \\
\hline $\mathrm{MnO}$ & 0 & 0.076 & 0 & 0.04 & 0.113 & 0.147 & 0.112 & 0.025 & 0.146 & 0.106 & 0.02 & 0 & 0.062 & 0.02 \\
\hline $\mathrm{MgO}$ & 18.215 & 17.34 & 17.363 & 10.989 & 10.471 & 11.112 & 11.026 & 11.402 & 10.344 & 17.815 & 17.966 & 18.479 & 19.535 & 19.346 \\
\hline $\mathrm{CaO}$ & 0.061 & 0.028 & 0.053 & 0 & 0.053 & 0 & 0.015 & 0.035 & 0.029 & 0 & 0.116 & 0.046 & 0.063 & 0 \\
\hline $\mathrm{Na} 2 \mathrm{O}$ & 0.05 & 0.053 & 0.038 & 0.025 & 0.076 & 0.021 & 0.051 & 0.049 & 0.05 & 0.113 & 0.29 & 0.18 & 0.132 & 0.505 \\
\hline $\mathrm{K} 2 \mathrm{O}$ & 9.753 & 9.289 & 9.926 & 9.576 & 9.549 & 9.489 & 9.488 & 9.419 & 9.527 & 9.685 & 9.283 & 8.749 & 8.181 & 8.745 \\
\hline $\mathrm{BaO}$ & 0.248 & 0.671 & 0.764 & 0.632 & 0.514 & 0.596 & 0.59 & 0.464 & 0.594 & 0.145 & 0.299 & 0.38 & 0.255 & 0.756 \\
\hline $\mathrm{F}$ & 0.457 & 0.434 & 0.227 & 1.569 & 1.372 & 1.502 & 1.706 & 1.673 & 1.504 & 0.245 & 0.381 & 0.137 & 0.215 & 0.48 \\
\hline $\mathrm{Cl}$ & 0.016 & 0.038 & 0.023 & 0.113 & 0.142 & 0.122 & 0.131 & 0.129 & 0.128 & 0.015 & 0.02 & 0.006 & 0.014 & 0.045 \\
\hline $\mathrm{Cr} 2 \mathrm{O} 3$ & 0.101 & 0.013 & 0.001 & 0 & 0.039 & 0 & 0 & 0.012 & 0 & 0.166 & 0.089 & 0.244 & 0.104 & 0.09 \\
\hline $\mathrm{NiO}$ & 0.163 & 0.129 & 0.099 & 0.043 & 0.01 & 0.039 & 0 & 0.014 & 0 & 0.109 & 0.052 & 0.056 & 0.078 & 0.109 \\
\hline $\mathrm{H} 2 \mathrm{O}^{*}$ & 3.401 & 5.722 & 3.52 & 3.015 & 2.664 & 1.864 & 2.691 & 2.808 & 1.956 & 2.891 & 4.057 & 4.543 & 3.662 & 3.87 \\
\hline Total & 100.195 & 100.192 & 100.1 & 100.685 & 100.609 & 100.661 & 100.749 & 100.731 & 100.662 & 100.106 & 100.168 & 100.059 & 100.092 & 100.211 \\
\hline $\mathrm{Si}$ & 5.532 & 5.750 & 5.556 & 5.542 & 5.603 & 5.527 & 5.518 & 5.564 & 5.499 & 5.590 & 5.612 & 5.558 & 5.454 & 5.506 \\
\hline Al iv & 2.468 & 2.250 & 2.444 & 2.458 & 2.397 & 2.473 & 2.482 & 2.436 & 2.501 & 2.410 & 2.388 & 2.442 & 2.546 & 2.494 \\
\hline Al vi & 0.155 & 0.207 & 0.258 & 0.051 & 0.075 & 0.012 & 0.038 & 0.042 & 0.020 & 0.356 & 0.427 & 0.298 & 0.269 & 0.332 \\
\hline $\mathrm{Ti}$ & 0.470 & 0.363 & 0.408 & 0.573 & 0.603 & 0.589 & 0.597 & 0.587 & 0.651 & 0.310 & 0.283 & 0.256 & 0.272 & 0.240 \\
\hline $\mathrm{Fe}$ & 1.173 & 1.292 & 1.265 & 2.510 & 2.506 & 2.555 & 2.498 & 2.435 & 2.588 & 1.276 & 1.164 & 1.327 & 1.303 & 1.143 \\
\hline $\mathrm{Mn}$ & 0.000 & 0.010 & 0.000 & 0.005 & 0.015 & 0.019 & 0.014 & 0.003 & 0.019 & 0.013 & 0.002 & 0.000 & 0.008 & 0.002 \\
\hline $\mathrm{Mg}$ & 3.923 & 3.839 & 3.765 & 2.508 & 2.374 & 2.508 & 2.508 & 2.584 & 2.341 & 3.811 & 3.870 & 4.019 & 4.194 & 4.175 \\
\hline $\mathrm{Ca}$ & 0.009 & 0.004 & 0.008 & 0.000 & 0.009 & 0.000 & 0.002 & 0.006 & 0.005 & 0.000 & 0.018 & 0.007 & 0.010 & 0.000 \\
\hline $\mathrm{Na}$ & 0.014 & 0.015 & 0.011 & 0.007 & 0.022 & 0.006 & 0.015 & 0.014 & 0.015 & 0.031 & 0.081 & 0.051 & 0.037 & 0.142 \\
\hline $\mathrm{K}$ & 1.797 & 1.760 & 1.842 & 1.870 & 1.852 & 1.833 & 1.847 & 1.827 & 1.845 & 1.773 & 1.711 & 1.628 & 1.503 & 1.615 \\
\hline $\mathrm{Ba}$ & 0.014 & 0.039 & 0.044 & 0.038 & 0.031 & 0.035 & 0.035 & 0.028 & 0.035 & 0.008 & 0.017 & 0.022 & 0.014 & 0.043 \\
\hline $\mathrm{F}$ & 0.209 & 0.204 & 0.104 & 0.760 & 0.660 & 0.719 & 0.823 & 0.805 & 0.722 & 0.111 & 0.174 & 0.063 & 0.098 & 0.220 \\
\hline $\mathrm{Cl}$ & 0.004 & 0.010 & 0.006 & 0.029 & 0.037 & 0.031 & 0.034 & 0.033 & 0.033 & 0.004 & 0.005 & 0.001 & 0.003 & 0.011 \\
\hline $\mathrm{Cr}$ & 0.012 & 0.002 & 0.000 & 0.000 & 0.005 & 0.000 & 0.000 & 0.001 & 0.000 & 0.019 & 0.010 & 0.028 & 0.012 & 0.010 \\
\hline $\mathrm{Ni}$ & 0.019 & 0.015 & 0.012 & 0.005 & 0.001 & 0.005 & 0.000 & 0.002 & 0.000 & 0.013 & 0.006 & 0.007 & 0.009 & 0.013 \\
\hline $\mathrm{OH}^{*}$ & 3.787 & 3.787 & 3.890 & 3.211 & 3.303 & 3.249 & 3.143 & 3.162 & 3.245 & 3.885 & 3.821 & 3.935 & 3.899 & 3.769 \\
\hline $\mathrm{Fe} / \mathrm{Fe}+\mathrm{Mg}$ & 0.230 & 0.252 & 0.251 & 0.500 & 0.514 & 0.505 & 0.499 & 0.485 & 0.525 & 0.251 & 0.231 & 0.248 & 0.237 & 0.215 \\
\hline Amostra & DM-10_c2_bt & DM-10_c2_bt & DM-10_c2_bt & DM-10_c2_bt & DM-10_c2_bt & DM-10_c2_bt & DM-13_c3_bt & DM-13_c3_bt & DM-13_c2_bt & DM-13_c2_bt & DM-13_c2_bt & DM-13_c2_bt & DM-13_c2_bt 5 & \\
\hline Prof. & 209.45 & 209.45 & 209.45 & 209.45 & 209.45 & 209.45 & 149.6 & 149.6 & 149.6 & 149.6 & 149.6 & 149.6 & 149.6 & \\
\hline Rocha & Pxt & Pxt & Pxt & Pxt & Pxt & Pxt & $\mathrm{Hzb}$ & $\mathrm{Hzb}$ & $\mathrm{Hzb}$ & $\mathrm{Hzb}$ & $\mathrm{Hzb}$ & $\mathrm{Hzb}$ & $\mathrm{Hzb}$ & \\
\hline $\mathrm{SiO} 2$ & 36.812 & 38.597 & 38.268 & 38.071 & 38.545 & 41.382 & 41.933 & 38.537 & 38.333 & 38.803 & 38.439 & 38.477 & 38.376 & \\
\hline $\mathrm{TiO} 2$ & 7.431 & 3.095 & 2.906 & 2.011 & 3.612 & 2.43 & 2.213 & 1.102 & 1.129 & 1.238 & 2.05 & 1.098 & 1.412 & \\
\hline $\mathrm{Al} 2 \mathrm{O} 3$ & 15.712 & 16.726 & 17.038 & 16.747 & 16.113 & 13.797 & 13.288 & 16.486 & 16.718 & 16.78 & 15.879 & 17.071 & 17.037 & \\
\hline $\mathrm{FeO}$ & 8.418 & 8.604 & 9.048 & 9.055 & 9.012 & 6.456 & 6.488 & 4.665 & 4.724 & 4.607 & 5.256 & 4.767 & 4.612 & \\
\hline $\mathrm{MnO}$ & 0 & 0.063 & 0.019 & 0.057 & 0 & 0.164 & 0.139 & 0.002 & 0 & 0.073 & 0.007 & 0.088 & 0 & \\
\hline $\mathrm{MgO}$ & 18.335 & 19.313 & 19.024 & 19.539 & 19.456 & 16.343 & 16.518 & 23.726 & 23.709 & 23.655 & 23.736 & 23.515 & 23.682 & \\
\hline $\mathrm{CaO}$ & 0.024 & 0 & 0.015 & 0.073 & 0.031 & 12.133 & 12.214 & 0.012 & 0.005 & 0 & 0.018 & 0 & 0 & \\
\hline $\mathrm{Na} 2 \mathrm{O}$ & 0.476 & 0.474 & 0.475 & 0.426 & 0.459 & 1.948 & 1.964 & 0.882 & 1.065 & 1.014 & 0.942 & 1.006 & 1.063 & \\
\hline $\mathrm{K} 2 \mathrm{O}$ & 8.227 & 8.718 & 8.701 & 8.777 & 8.491 & 1.25 & 1.293 & 8.968 & 8.669 & 8.637 & 8.828 & 8.858 & 8.734 & \\
\hline $\mathrm{BaO}$ & 0.914 & 0.776 & 0.777 & 1.012 & 0.969 & 0 & 0.033 & 0.366 & 0.436 & 0.453 & 0.333 & 0.422 & 0.315 & \\
\hline $\mathrm{F}$ & 0.568 & 0.571 & 0.591 & 0.54 & 0.492 & 0.174 & 0.069 & 0.349 & 0.266 & 0.243 & 0.478 & 0.157 & 0.183 & \\
\hline $\mathrm{Cl}$ & 0.075 & 0.089 & 0.046 & 0.045 & 0.069 & 0.018 & 0.021 & 0.024 & 0.016 & 0.01 & 0 & 0.024 & 0.012 & \\
\hline Cr2O3 & 0.141 & 0.155 & 0.064 & 0.142 & 0.063 & 0.287 & 0.339 & 0.17 & 0.158 & 0.327 & 0.288 & 0.273 & 0.211 & \\
\hline $\mathrm{NiO}$ & 0 & 0.15 & 0.008 & 0.029 & 0.111 & 0.081 & 0.068 & 0.083 & 0.098 & 0.079 & 0.042 & 0.04 & 0.081 & \\
\hline $\mathrm{H} 2 \mathrm{O}^{*}$ & 3.122 & 2.931 & 3.28 & 3.713 & 2.802 & 3.614 & 3.452 & 4.776 & 4.788 & 4.186 & 3.905 & 4.279 & 4.362 & \\
\hline Total & 100.255 & 100.262 & 100.26 & 100.237 & 100.225 & 100.077 & 100.032 & 100.148 & 100.114 & 100.105 & 100.201 & 100.075 & 100.08 & \\
\hline $\mathrm{Si}$ & 5.286 & 5.511 & 5.489 & 5.503 & 5.507 & 5.806 & 5.871 & 5.500 & 5.468 & 5.492 & 5.460 & 5.460 & 5.440 & \\
\hline Al iv & 2.659 & 2.489 & 2.511 & 2.497 & 2.493 & 2.194 & 2.129 & 2.500 & 2.532 & 2.508 & 2.540 & 2.540 & 2.560 & \\
\hline Al vi & 0.000 & 0.325 & 0.369 & 0.356 & 0.220 & 0.088 & 0.063 & 0.273 & 0.279 & 0.292 & 0.118 & 0.315 & 0.287 & \\
\hline $\mathrm{Ti}$ & 0.802 & 0.332 & 0.313 & 0.219 & 0.388 & 0.256 & 0.233 & 0.118 & 0.121 & 0.132 & 0.219 & 0.117 & 0.151 & \\
\hline $\mathrm{Fe}$ & 1.011 & 1.027 & 1.085 & 1.095 & 1.077 & 0.758 & 0.760 & 0.557 & 0.564 & 0.545 & 0.624 & 0.566 & 0.547 & \\
\hline $\mathrm{Mn}$ & 0.000 & 0.008 & 0.002 & 0.007 & 0.000 & 0.019 & 0.016 & 0.000 & 0.000 & 0.009 & 0.001 & 0.011 & 0.000 & \\
\hline $\mathrm{Mg}$ & 3.925 & 4.110 & 4.068 & 4.210 & 4.144 & 3.418 & 3.447 & 5.048 & 5.042 & 4.991 & 5.026 & 4.974 & 5.004 & \\
\hline $\mathrm{Ca}$ & 0.004 & 0.000 & 0.002 & 0.011 & 0.005 & 1.824 & 1.832 & 0.002 & 0.001 & 0.000 & 0.003 & 0.000 & 0.000 & \\
\hline $\mathrm{Na}$ & 0.133 & 0.131 & 0.132 & 0.119 & 0.127 & 0.530 & 0.533 & 0.244 & 0.295 & 0.278 & 0.259 & 0.277 & 0.292 & \\
\hline $\mathrm{K}$ & 1.507 & 1.588 & 1.592 & 1.618 & 1.547 & 0.224 & 0.231 & 1.633 & 1.577 & 1.559 & 1.599 & 1.603 & 1.579 & \\
\hline $\mathrm{Ba}$ & 0.051 & 0.043 & 0.044 & 0.057 & 0.054 & 0.000 & 0.002 & 0.020 & 0.024 & 0.025 & 0.019 & 0.023 & 0.017 & \\
\hline $\mathrm{F}$ & 0.258 & 0.258 & 0.268 & 0.247 & 0.222 & 0.077 & 0.031 & 0.158 & 0.120 & 0.109 & 0.215 & 0.070 & 0.082 & \\
\hline $\mathrm{Cl}$ & 0.018 & 0.022 & 0.011 & 0.011 & 0.017 & 0.004 & 0.005 & 0.006 & 0.004 & 0.002 & 0.000 & 0.006 & 0.003 & \\
\hline $\mathrm{Cr}$ & 0.016 & 0.017 & 0.007 & 0.016 & 0.007 & 0.032 & 0.038 & 0.019 & 0.018 & 0.037 & 0.032 & 0.031 & 0.024 & \\
\hline $\mathrm{Ni}$ & 0.000 & 0.017 & 0.001 & 0.003 & 0.013 & 0.009 & 0.008 & 0.010 & 0.011 & 0.009 & 0.005 & 0.005 & 0.009 & \\
\hline $\mathrm{OH}^{*}$ & 3.724 & 3.721 & 3.721 & 3.742 & 3.761 & 3.919 & 3.964 & 3.837 & 3.876 & 3.889 & 3.785 & 3.924 & 3.915 & \\
\hline $\mathrm{Fe} / \mathrm{Fe}+\mathrm{Mg}$ & 0.205 & 0.200 & 0.211 & 0.206 & 0.206 & 0.181 & 0.181 & 0.099 & 0.101 & 0.099 & 0.111 & 0.102 & 0.098 & \\
\hline
\end{tabular}




\section{ILMENITA}

\begin{tabular}{|c|c|c|c|c|c|c|c|c|c|c|c|c|c|c|c|}
\hline \multirow{3}{*}{\begin{tabular}{|l} 
Amostra \\
Prof. \\
Rocha
\end{tabular}} & \multicolumn{6}{|c|}{ M-06A-C1-IIm M-06A-C1-IIm M-06A-C1-IIm M-06A-C1-IIm M-06A-C1-IIm M-06A-C2-IIm } & \multicolumn{4}{|c|}{ M-06A-C2-IIm M-06A-C2-IIm M-06A-C2-IIm DM-14-C2-IIm } & \multicolumn{5}{|c|}{ DM-14-C2-IIm 216-2_C1_ilm 1_-16-2_C1_ilm 16-2_C1_ilm 116-2_C1_ilm 2} \\
\hline & 220.2 & 220.2 & 220.2 & 220.2 & 220.2 & 220.2 & 220.2 & 220.2 & 220.2 & 102.4 & 102.4 & 68.25 & 68.25 & 68.25 & 68.25 \\
\hline & Xnt & Xnt & Xnt & Xnt & Xnt & Xnt & Xnt & Xnt & Xnt & OIOpxt & OIOpxt & GbrNrt & GbrNrt & GbrNrt & GbrNrt \\
\hline $\mathrm{SiO}_{2}(\mathrm{wt} \%)$ & 0.052 & 0.061 & 0.061 & 0.028 & 0.071 & 0.032 & 0.047 & 0.062 & 0.082 & 0.05 & 0.089 & 0.028 & 0.066 & 0.063 & 0.301 \\
\hline $\mathrm{TiO}_{2}(\mathrm{wt} \%)$ & 51.391 & 49.548 & 47.303 & 51.484 & 51.195 & 51.393 & 52.253 & 51.396 & 52.588 & 52.217 & 53.42 & 50.49 & 45.37 & 47.514 & 46.418 \\
\hline $\mathrm{Al}_{2} \mathrm{O}_{3}(\mathrm{wt} \%)$ & 0.007 & 0 & 0.021 & 0.015 & 0.018 & 0 & 0.002 & 0.017 & 0.04 & 0 & 0 & 0 & 0.049 & 0.016 & 0.009 \\
\hline $\mathrm{Cr}_{2} \mathrm{O}_{3}(\mathrm{wt} \%)$ & 0.13 & 0.243 & 0.29 & 0.23 & 0.282 & 0.016 & 0.075 & 0.123 & 0.092 & 0.184 & 0.175 & & & & \\
\hline $\mathrm{FeO}(\mathrm{wt} \%)$ & 46.117 & 46.852 & 47.096 & 45.945 & 46.075 & 46.711 & 46.437 & 46.302 & 45.858 & 42.671 & 43.026 & 49.284 & 51.171 & 50.655 & 49.895 \\
\hline $\mathrm{MgO}(\mathrm{wt} \%)$ & 1.998 & 1.993 & 1.996 & 1.723 & 1.7 & 0.83 & 0.784 & 0.892 & 0.881 & 3.718 & 3.509 & 0.604 & 0.645 & 0.608 & 0.606 \\
\hline $\mathrm{CaO}(\mathrm{wt} \%)$ & 0.007 & 0.021 & 0.082 & 0.025 & 0.033 & 0 & 0.018 & 0.062 & 0.04 & 0.046 & 0.007 & 0.043 & 0 & 0 & 0.016 \\
\hline $\mathrm{V}_{2} \mathrm{O}_{3}(\mathrm{wt} \%)$ & 0.659 & 0.597 & 0.602 & 0.622 & 0.732 & 0.565 & 0.522 & 0.615 & 0.607 & 0.432 & 0.419 & & & & \\
\hline$(\mathrm{OH})$ & 0 & 0.666 & 2.459 & 0 & 0 & 0.439 & 0 & 0.518 & 0 & 0.681 & 0 & & & & \\
\hline total & 100.361 & 99.981 & 99.91 & 100.072 & 100.106 & 99.986 & 100.138 & 99.987 & 100.188 & 99.999 & 100.645 & 100.449 & 97.301 & 98.856 & 97.245 \\
\hline $\mathrm{Si}$ & 0.001 & 0.002 & 0.002 & 0.001 & 0.002 & 0.001 & 0.001 & 0.002 & 0.002 & 0.001 & 0.002 & 0.001 & 0.002 & 0.002 & 0.008 \\
\hline $\mathrm{Ti}$ & 0.955 & 0.930 & 0.902 & 0.962 & 0.957 & 0.973 & 0.984 & 0.973 & 0.989 & 0.969 & 0.980 & 0.947 & 0.875 & 0.904 & 0.897 \\
\hline $\mathrm{Cr}$ & 0.003 & 0.005 & 0.006 & 0.005 & 0.006 & 0.000 & 0.001 & 0.002 & 0.002 & 0.004 & 0.003 & & & & \\
\hline V & 0.013 & 0.012 & 0.012 & 0.012 & 0.015 & 0.011 & 0.010 & 0.012 & 0.012 & 0.009 & 0.008 & & & & \\
\hline Al & 0.000 & 0.000 & 0.001 & 0.000 & 0.001 & 0.000 & 0.000 & 0.001 & 0.001 & 0.000 & 0.000 & 0.000 & 0.001 & 0.000 & 0.000 \\
\hline $\mathrm{Fe}^{+3}$ & 0.000 & 0.000 & 0.000 & 0.000 & 0.000 & 0.000 & 0.000 & 0.000 & 0.000 & 0.000 & 0.000 & 0.104 & 0.245 & 0.189 & 0.191 \\
\hline $\mathrm{Mg}$ & 0.074 & 0.074 & 0.075 & 0.064 & 0.063 & 0.031 & 0.029 & 0.033 & 0.033 & 0.137 & 0.128 & 0.000 & 0.000 & 0.000 & 0.000 \\
\hline $\mathrm{Fe}^{+2}$ & 0.881 & 0.856 & 0.824 & 0.899 & 0.895 & 0.942 & 0.956 & 0.939 & 0.957 & 0.832 & 0.854 & 0.000 & 0.000 & 0.000 & 0.000 \\
\hline $\mathrm{Ca}$ & 0.000 & 0.001 & 0.002 & 0.001 & 0.001 & 0.000 & 0.000 & 0.002 & 0.001 & 0.001 & 0.000 & 0.001 & 0.000 & 0.000 & 0.000 \\
\hline \% IImenita & 88.370 & 85.888 & 82.815 & 90.132 & 89.780 & 94.272 & 95.701 & 94.191 & 95.933 & 83.450 & 85.612 & 92.531 & 85.203 & 88.245 & 88.120 \\
\hline$\%$ Geikielita & 7.378 & 7.435 & 7.581 & 6.403 & 6.319 & 3.115 & 2.931 & 3.357 & 3.293 & 13.711 & 12.791 & 2.248 & 2.465 & 2.292 & 2.321 \\
\hline$\%$ Hematita & 3.582 & 6.079 & 8.765 & 2.822 & 3.143 & 2.042 & 0.841 & 1.775 & 0.105 & 2.411 & 1.186 & 5.187 & 12.257 & 9.439 & 9.545 \\
\hline$\%$ Córindon & 0.010 & 0.000 & 0.032 & 0.022 & 0.026 & 0.000 & 0.003 & 0.025 & 0.059 & 0.000 & 0.000 & 0.000 & 0.074 & 0.024 & 0.014 \\
\hline$\%$ Karelianita & 0.654 & 0.599 & 0.615 & 0.621 & 0.732 & 0.570 & 0.525 & 0.622 & 0.610 & 0.428 & 0.411 & 0.000 & 0.000 & 0.000 & 0.000 \\
\hline Amostra & -16-2_C1_ilm 2 & 2_C1_ilm & 6-2_C4_il & 6-2_C4_ilr & 6-2_C4_ilm & 6_C4_ilm & M-16_C4_ilm & M-16_C4_ilm & M-16_C5_ilm & M-16_C5_ilm & M-16_C5_ilm & M-16_C3_ilm & M-16_C3_ilm & M-16_C3_ilm $\Phi$ & \\
\hline $\begin{array}{l}\text { Prof. } \\
\text { Rocha }\end{array}$ & $\begin{array}{l}68.25 \\
\text { GbrNrt }\end{array}$ & $\begin{array}{l}68.25 \\
\text { GbrNrt }\end{array}$ & $\begin{array}{l}68.25 \\
\text { GbrNrt }\end{array}$ & $\begin{array}{l}68.25 \\
\text { GbrNrt }\end{array}$ & $\begin{array}{l}68.25 \\
\text { GbrNrt }\end{array}$ & $\begin{array}{r}68.25 \\
\text { GbrNrt }\end{array}$ & $\begin{array}{l}68.25 \\
\text { GbrNrt }\end{array}$ & $\begin{array}{l}68.25 \\
\text { GbrNrt }\end{array}$ & $\begin{array}{l}68.25 \\
\text { GbrNrt }\end{array}$ & $\begin{array}{l}68.25 \\
\text { GbrNrt }\end{array}$ & $\begin{array}{l}68.25 \\
\text { GbrNrt }\end{array}$ & $\begin{array}{l}68.25 \\
\text { GbrNrt }\end{array}$ & $\begin{array}{l}68.25 \\
\text { GbrNrt }\end{array}$ & $\begin{array}{l}68.25 \\
\text { GbrNrt }\end{array}$ & \\
\hline $\mathrm{SiO}_{2}(\mathrm{wt} \%)$ & 0.024 & 0.057 & 0 & 0.042 & 0 & 0.022 & 0.036 & 0.031 & 0.012 & 0.019 & 0.005 & 0.051 & 0.001 & 0.01 & \\
\hline $\mathrm{TiO}_{2}$ (wt\%) & 46.865 & 46.274 & 47.737 & 48.244 & 48.719 & 47.494 & 45.496 & 47.438 & 46.707 & 43.576 & 47.792 & 47.126 & 49.08 & 44.635 & \\
\hline $\begin{array}{l}\mathrm{Al}_{2} \mathrm{O}_{3}(\mathrm{wt} \%) \\
\mathrm{Cr}_{2} \mathrm{O}_{3}(\mathrm{wt} \%)\end{array}$ & 0 & 0.007 & 0.02 & 0 & 0.005 & 0.043 & 0.331 & 0.008 & 0.762 & 0.058 & 0.013 & 0 & 0.046 & 0.029 & \\
\hline $\mathrm{FeO}(\mathrm{wt} \%)$ & 52.177 & 51.051 & 50.223 & 51.663 & 50.505 & 52.423 & 51.594 & 50.913 & 50.257 & 53.24 & 52.059 & 52.892 & 51.837 & 54.628 & \\
\hline $\mathrm{MgO}(\mathrm{wt} \%)$ & 0.633 & 0.714 & 0.626 & 0.551 & 0.599 & 0.66 & 0.626 & 0.658 & 0.703 & 0.612 & 0.573 & 0.616 & 0.437 & 0.483 & \\
\hline $\mathrm{CaO}(\mathrm{wt} \%)$ & 0.009 & 0.053 & 0.022 & 0.013 & 0 & 0.013 & 0 & 0.028 & 0.005 & 0 & 0.007 & 0 & 0.028 & 0.001 & \\
\hline \multicolumn{16}{|l|}{$\mathrm{V}_{2} \mathrm{O}_{3}(\mathrm{wt} \%)$} \\
\hline \multicolumn{16}{|l|}{$(\mathrm{OH})$} \\
\hline total & 99.708 & 98.156 & 98.628 & 100.513 & 99.828 & 100.655 & 98.083 & 99.076 & 98.446 & 97.505 & 100.449 & 100.685 & 101.429 & 99.786 & \\
\hline $\mathrm{Si}$ & 0.001 & 0.001 & 0.000 & 0.001 & 0.000 & 0.001 & 0.001 & 0.001 & 0.000 & 0.000 & 0.000 & 0.001 & 0.000 & 0.000 & \\
\hline $\mathrm{Ti}$ & 0.883 & 0.885 & 0.910 & 0.903 & 0.919 & 0.886 & 0.869 & 0.900 & 0.888 & 0.837 & 0.895 & 0.879 & 0.912 & 0.839 & \\
\hline \multicolumn{16}{|l|}{$\begin{array}{l}\mathrm{Cr} \\
\mathrm{V}\end{array}$} \\
\hline V & & & & & & & & & & & & & & & \\
\hline Al & 0.000 & 0.000 & 0.001 & 0.000 & 0.000 & 0.001 & 0.010 & 0.000 & 0.023 & 0.002 & 0.000 & 0.000 & 0.001 & 0.001 & \\
\hline $\mathrm{Fe}^{+3}$ & 0.233 & 0.227 & 0.179 & 0.192 & 0.163 & 0.225 & 0.250 & 0.199 & 0.201 & 0.323 & 0.210 & 0.239 & 0.176 & 0.320 & \\
\hline $\mathrm{Mg}$ & 0.000 & 0.000 & 0.000 & 0.000 & 0.000 & 0.000 & 0.000 & 0.000 & 0.000 & 0.000 & 0.000 & 0.000 & 0.000 & 0.000 & \\
\hline $\mathrm{Fe}+2$ & 0.000 & 0.000 & 0.000 & 0.000 & 0.000 & 0.000 & 0.000 & 0.000 & 0.000 & 0.000 & 0.000 & 0.000 & 0.000 & 0.000 & \\
\hline $\mathrm{Ca}$ & 0.000 & 0.001 & 0.001 & 0.000 & 0.000 & 0.000 & 0.000 & 0.001 & 0.000 & 0.000 & 0.000 & 0.000 & 0.001 & 0.000 & \\
\hline$\%$ Ilmenita & 85.974 & 85.890 & 88.622 & 88.360 & 89.628 & 86.218 & 84.658 & 87.577 & 86.183 & 81.441 & 87.343 & 85.755 & 89.488 & 82.136 & \\
\hline$\%$ Geikielita & 2.364 & 2.709 & 2.366 & 2.045 & 2.239 & 2.441 & 2.371 & 2.475 & 2.649 & 2.330 & 2.126 & 2.277 & 1.609 & 1.800 & \\
\hline$\%$ Hematita & 11.663 & 11.390 & 8.937 & 9.595 & 8.126 & 11.278 & 12.476 & 9.936 & 10.033 & 16.141 & 10.507 & 11.967 & 8.782 & 16.022 & \\
\hline \% Córindon & 0.000 & 0.010 & 0.030 & 0.000 & 0.007 & 0.063 & 0.495 & 0.012 & 1.135 & 0.087 & 0.019 & 0.000 & 0.067 & 0.043 & \\
\hline$\%$ Karelianita & 0.000 & 0.000 & 0.000 & 0.000 & 0.000 & 0.000 & 0.000 & 0.000 & 0.000 & 0.000 & 0.000 & 0.000 & 0.000 & 0.000 & \\
\hline
\end{tabular}




\section{CROMITA}

\begin{tabular}{|c|c|c|c|c|c|c|}
\hline Amostra & \multicolumn{6}{|c|}{ M-13-C5-Chr 1M-13-C5-Chr 2M-13-C5-Chr 3M-13-C4-Chr 1M-13-C1-Chr 1M-13-C1-Chr } \\
\hline Prof. & 149.6 & 149.6 & 149.6 & 149.6 & 149.6 & 149.6 \\
\hline Rocha & $\mathrm{Hzb}$ & $\mathrm{Hzb}$ & $\mathrm{Hzb}$ & $\mathrm{Hzb}$ & $\mathrm{Hzb}$ & $\mathrm{Hzb}$ \\
\hline $\mathrm{SiO}_{2}(\mathrm{wt} \%)$ & 0 & 0.043 & 0.018 & 0 & 0.008 & 0.014 \\
\hline $\mathrm{TiO}_{2}(\mathrm{wt} \%)$ & 0.112 & 0.104 & 0.08 & 0.275 & 0.124 & 0 \\
\hline $\mathrm{Al}_{2} \mathrm{O}_{3}(\mathrm{wt} \%)$ & 42.059 & 42.716 & 42.245 & 43.879 & 43.604 & 43.508 \\
\hline $\mathrm{Cr}_{2} \mathrm{O}_{3}(\mathrm{wt} \%)$ & 11.625 & 12.128 & 11.685 & 11.529 & 12.033 & 11.606 \\
\hline $\mathrm{FeO}(\mathrm{wt} \%)$ & 29.612 & 28.702 & 29.059 & 27.151 & 28.385 & 28.79 \\
\hline $\mathrm{MgO}(\mathrm{wt} \%)$ & 10.508 & 10.715 & 10.326 & 12.366 & 10.76 & 10.967 \\
\hline $\mathrm{CaO}(w t \%)$ & 0 & 0.015 & 0 & 0 & 0.019 & 0 \\
\hline $\mathrm{NiO}(w t \%)$ & 0.153 & 0.162 & 0.18 & 0.152 & 0.184 & 0.195 \\
\hline $\mathrm{V}_{2} \mathrm{O}_{3}(\mathrm{wt} \%)$ & 0.15 & 0.062 & 0.117 & 0.099 & 0.132 & 0.144 \\
\hline$(\mathrm{OH})$ & 5.781 & 5.353 & 6.29 & 4.548 & 4.752 & 4.776 \\
\hline Total & 100 & 100 & 100 & 99.999 & 100.001 & 100 \\
\hline $\mathrm{Ni}$ & 0.004 & 0.004 & 0.004 & 0.004 & 0.004 & 0.005 \\
\hline $\mathrm{Si}$ & 0.000 & 0.001 & 0.001 & 0.000 & 0.000 & 0.000 \\
\hline $\mathrm{Ti}$ & 0.003 & 0.002 & 0.002 & 0.006 & 0.003 & 0.000 \\
\hline $\mathrm{Cr}$ & 0.277 & 0.287 & 0.280 & 0.267 & 0.282 & 0.272 \\
\hline V & 0.004 & 0.001 & 0.003 & 0.002 & 0.003 & 0.003 \\
\hline Al & 1.494 & 1.507 & 1.508 & 1.515 & 1.526 & 1.521 \\
\hline $\mathrm{Fe}+3$ & 0.219 & 0.197 & 0.202 & 0.203 & 0.182 & 0.199 \\
\hline $\mathrm{Mg}$ & 0.472 & 0.478 & 0.466 & 0.538 & 0.476 & 0.485 \\
\hline $\mathrm{Fe}^{+2}$ & 0.527 & 0.521 & 0.532 & 0.462 & 0.522 & 0.511 \\
\hline $\mathrm{Ca}$ & 0.000 & 0.000 & 0.000 & 0.000 & 0.001 & 0.000 \\
\hline$\%$ Magnetita & 10.628 & 9.492 & 9.791 & 9.798 & 8.709 & 9.694 \\
\hline \% Ulvo-espinéli & 0.254 & 0.234 & 0.182 & 0.606 & 0.277 & 0.000 \\
\hline$\%$ Cromita & 13.853 & 14.369 & 13.999 & 13.355 & 14.124 & 13.611 \\
\hline$\%$ Hercinita & 27.487 & 27.563 & 28.789 & 21.744 & 28.662 & 27.553 \\
\hline \% Espinélio & 47.226 & 47.877 & 46.657 & 54.023 & 47.632 & 48.506 \\
\hline$\%$ Coulsonita & 0.181 & 0.074 & 0.142 & 0.116 & 0.157 & 0.171 \\
\hline$\%$ Trevorita & 0.371 & 0.391 & 0.439 & 0.358 & 0.439 & 0.465 \\
\hline
\end{tabular}


PENTLANDITA

\begin{tabular}{|c|c|c|c|c|c|c|c|c|c|c|c|c|}
\hline \multirow{3}{*}{$\begin{array}{l}\text { Amostra } \\
\text { Prof. } \\
\text { Rocha }\end{array}$} & \multicolumn{12}{|c|}{ M-14_C2_pnt M-14_C2_pnt M-14_C2_pnt M-14_C2_pnt M-14_C2_pnt 1M-14_C2_pnt 1M-14_C3_pnt M-14_C3_pnt M-14_C3_pnt M-13_C4_pnt M-13_C4_pnt M-06B_C1_pnt } \\
\hline & 102.4 & 102.4 & 102.4 & 102.4 & 102.4 & 102.4 & 102.4 & 102.4 & 102.4 & 149.6 & 149.6 & 220.4 \\
\hline & OlOpxt & OlOpxt & OIOpxt & OlOpxt & OIOpxt & OIOpxt & OIOpxt & OlOpxt & OIOpxt & $\mathrm{Hzb}$ & $\mathrm{Hzb}$ & Pxt \\
\hline As & 0 & 0 & 0 & 0 & 0 & 0 & 0 & 0 & 0 & 0 & 0 & 0 \\
\hline $\mathrm{Ga}$ & 0 & 0 & 0 & 0 & 0 & 0 & 0 & 0 & 0 & 0 & 0 & 0 \\
\hline $\mathrm{Se}$ & 0 & 0.045 & 0.021 & 0 & 0 & 0.011 & 0.012 & 0 & 0.035 & 0.035 & 0.002 & 0.003 \\
\hline$S$ & 32.79 & 32.284 & 31.173 & 33.714 & 32.447 & 33.905 & 32.56 & 32.728 & 32.127 & 33.294 & 32.115 & 33.748 \\
\hline $\mathrm{Bi}$ & 0 & 0 & 0 & 0 & 0 & 0 & 0 & 0 & 0.041 & 0 & 0 & 0 \\
\hline $\mathrm{Te}$ & 0.122 & 0.208 & 0.121 & 0.119 & 0.134 & 0.125 & 0.105 & 0.146 & 0.096 & 0.217 & 0.103 & 0.118 \\
\hline $\mathrm{Fe}$ & 31.445 & 30.374 & 30.772 & 32.289 & 32.286 & 32.366 & 32.16 & 33.417 & 35.688 & 34.678 & 36.127 & 32.385 \\
\hline Co & 1.477 & 1.407 & 1.523 & 0.581 & 0.959 & 2.018 & 1.61 & 1.434 & 0.28 & 1.942 & 1.513 & 0.655 \\
\hline $\mathrm{Cu}$ & 0 & 0 & 0 & 0 & 0 & 0 & 0 & 0 & 0 & 0 & 0 & 0 \\
\hline $\mathrm{Sb}$ & 0.028 & 0 & 0 & 0.006 & 0.155 & 0.055 & 0 & 0 & 0.041 & 0.28 & 0 & 0.06 \\
\hline $\mathrm{Ni}$ & 30.621 & 30.813 & 30.706 & 30.728 & 30.604 & 30.305 & 30.626 & 30.091 & 30.085 & 30.087 & 30.026 & 30.507 \\
\hline $\mathrm{Au}$ & 0.01 & 0 & 0 & 0 & 0 & 0.005 & 0 & 0 & 0 & 0 & 0.033 & 0 \\
\hline $\mathrm{Ag}$ & 0 & 0.027 & 0.012 & 0.013 & 0 & 0 & 0.005 & 0.022 & 0.006 & 0 & 0.021 & 0.014 \\
\hline $\mathrm{Pd}$ & 0.009 & 0 & 0 & 0.005 & 0.03 & 0 & 0.002 & 0.008 & 0 & 0 & 0 & 0 \\
\hline $\mathrm{Pt}$ & 0 & 0 & 0 & 0 & 0.001 & 0 & 0 & 0 & 0 & 0.002 & 0 & 0 \\
\hline total & 96.648 & 95.506 & 94.543 & 97.675 & 96.722 & 98.885 & 97.308 & 98.071 & 98.588 & 100.785 & 100.132 & 97.632 \\
\hline Amostra & \multicolumn{12}{|c|}{ M-06B_C1_pntM-06B_C3_pntM-06B_C3_pntM-06B_C3_pntM-06A_C1_pntM-06A_C1_pnt -06A_C1_pnt -06A_C1_pnt -06A_C1_pnt M-06A_C3_pntM-06A_C3_pntM-06A_C3_pnt } \\
\hline Prof. & 220.4 & 220.4 & 220.4 & 220.4 & 220.2 & 220.2 & 220.2 & 220.2 & 220.2 & 220.2 & 220.2 & 220.2 \\
\hline Rocha & Pxt & Pxt & Pxt & Pxt & Xnt & Xnt & Xnt & Xnt & Xnt & Xnt & Xnt & Xnt \\
\hline As & 0 & 0 & 0 & 0 & 0 & 0 & 0 & 0 & 0 & 0 & 0 & 0 \\
\hline $\mathrm{Zn}$ & 0.041 & 0.052 & 0 & 0.022 & 0.017 & 0.056 & 0.075 & 0.016 & 0 & 0.02 & 0 & 0 \\
\hline $\mathrm{Ga}$ & 0 & 0 & 0 & 0 & 0 & 0 & 0 & 0 & 0 & 0 & 0 & 0 \\
\hline $\mathrm{Se}$ & 0 & 0 & 0 & 0.043 & 0.031 & 0 & 0.027 & 0.006 & 0.024 & 0 & 0 & 0 \\
\hline$S$ & 33.913 & 33.098 & 33.052 & 32.371 & 32.922 & 33.27 & 33.079 & 32.552 & 32.946 & 33.11 & 32.526 & 33.576 \\
\hline $\mathrm{Pb}$ & 0.133 & 0.133 & 0.187 & 0.047 & 0.168 & 0.11 & 0.167 & 0.006 & 0.136 & 0.092 & 0.161 & 0.104 \\
\hline $\mathrm{Bi}$ & 0 & 0 & 0 & 0 & 0 & 0 & 0.068 & 0.018 & 0 & 0 & 0 & 0 \\
\hline Co & 0.865 & 0.848 & 1.291 & 0.728 & 0.752 & 1.063 & 1.108 & 1.064 & 0.96 & 0.714 & 1.162 & 1.027 \\
\hline $\mathrm{Cu}$ & 0 & 0 & 0 & 0 & 0 & 0 & 0 & 0 & 0 & 0 & 0 & 0 \\
\hline $\mathrm{Sb}$ & 0.033 & 0.007 & 0 & 0 & 0.09 & 0.012 & 0.038 & 0.084 & 0.002 & 0.084 & 0.057 & 0.103 \\
\hline $\mathrm{Ni}$ & 30.702 & 30.382 & 30.431 & 20.876 & 30.476 & 30.467 & 30.373 & 30.501 & 30.367 & 30.206 & 30.356 & 30.691 \\
\hline Mo & 0.026 & 0.066 & 0.099 & 0.085 & 0.049 & 0.091 & 0.047 & 0.074 & 0.073 & 0.061 & 0.028 & 0.089 \\
\hline $\mathrm{Au}$ & 0.015 & 0 & 0 & 0 & 0 & 0 & 0 & 0.014 & 0 & 0 & 0 & 0.003 \\
\hline $\mathrm{Ag}$ & 0 & 0.009 & 0 & 0.011 & 0.019 & 0 & 0 & 0.02 & 0.007 & 0.079 & 0.018 & 0.004 \\
\hline $\mathrm{Pd}$ & 0 & 0 & 0.024 & 0 & 0 & 0 & 0.009 & 0 & 0 & 0 & 0 & 0 \\
\hline $\mathrm{Pt}$ & 0 & 0 & 0.015 & 0 & 0.014 & 0 & 0 & 0 & 0 & 0.004 & 0 & 0 \\
\hline total & 98.291 & 96.675 & 96.652 & 99.369 & 104.95 & 97.1 & 97.445 & 97.229 & 96.868 & 96.394 & 97.733 & 102.279 \\
\hline Amostra & \multicolumn{12}{|c|}{ M-06A_C3_pntM-06A_C4_pntM-06A_C4_pntM-06A_C4_pnt -06A_C4_pnt -06A_C4_pnt -06A_C4_pnt } \\
\hline Prof. & 220.2 & 220.2 & 220.2 & 220.2 & 220.2 & 220.2 & 220.2 & & & & & \\
\hline Rocha & Xnt & Xnt & Xnt & Xnt & Xnt & Xnt & Xnt & & & & & \\
\hline As & 0 & 0 & 0 & 0 & 0 & 0 & 0 & & & & & \\
\hline $\mathrm{Zn}$ & 0.003 & 0 & 0 & 0 & 0 & 0.038 & 0 & & & & & \\
\hline $\mathrm{Ga}$ & 0 & 0 & 0 & 0 & 0 & 0 & 0 & & & & & \\
\hline $\mathrm{Se}$ & 0.013 & 0.021 & 0.035 & 0 & 0.037 & 0.031 & 0.013 & & & & & \\
\hline$S$ & 33.811 & 33.956 & 32.725 & 32.927 & 33.081 & 33.125 & 32.244 & & & & & \\
\hline $\mathrm{Pb}$ & 0.19 & 0.182 & 0.08 & 0.114 & 0.171 & 0.185 & 0.17 & & & & & \\
\hline $\mathrm{Bi}$ & 0 & 0 & 0.119 & 0.018 & 0 & 0 & 0.016 & & & & & \\
\hline $\mathrm{Te}$ & 0.099 & 0.121 & 0.118 & 0.123 & 0.155 & 0.127 & 0.2 & & & & & \\
\hline $\mathrm{Fe}$ & 32.312 & 32.238 & 31.049 & 31.86 & 31.753 & 31.935 & 32.01 & & & & & \\
\hline Co & 1.815 & 0.966 & 0.838 & 0.9 & 0.932 & 1.078 & 1.067 & & & & & \\
\hline $\mathrm{Cu}$ & 0 & 0 & 0 & 0 & 0 & 0 & 0 & & & & & \\
\hline $\mathrm{Sb}$ & 0.025 & 0.041 & 0.058 & 0 & 0 & 0.105 & 0 & & & & & \\
\hline $\mathrm{Ni}$ & 30.433 & 30.266 & 30.214 & 30.647 & 30.531 & 30.429 & 30.5 & & & & & \\
\hline Mo & 0.061 & 0.038 & 0.135 & 0.061 & 0.073 & 0.108 & 0.051 & & & & & \\
\hline $\mathrm{Au}$ & 0 & 0 & 0 & 0 & 0 & 0.028 & 0 & & & & & \\
\hline $\mathrm{Ag}$ & 0.009 & 0.023 & 0 & 0.007 & 0 & 0 & 0 & & & & & \\
\hline $\mathrm{Pd}$ & 0 & 0 & 0 & 0 & 0 & 0 & 0 & & & & & \\
\hline $\mathrm{Pt}$ & 0 & 0 & 0.008 & 0.054 & 0 & 0 & 0 & & & & & \\
\hline
\end{tabular}




\section{PIRROTITA}

\begin{tabular}{|c|c|c|c|c|c|c|c|c|c|c|c|c|}
\hline \multirow{3}{*}{$\begin{array}{l}\text { Amostra } \\
\text { Prof. } \\
\text { Rocha }\end{array}$} & \multicolumn{12}{|c|}{ M-14_C1_po 1M-14_C1_po 2M-14_C1_po 3M-14_C1_po 4M-14_C1_po 5M-14_C1_po 1M-14_C1_po 2M-14_C1_po 5M-14_C1_po 6M-14_C1_po 7M-14_C1_po 8M-14_C1_po 9 } \\
\hline & 102.4 & 102.4 & 102.4 & 102.4 & $102 . \overline{4}$ & 102.4 & $\overline{102.4}$ & 102.4 & 102.4 & 102.4 & 102.4 & 102.4 \\
\hline & OlOpxt & OlOpxt & OlOpxt & OlOpxt & OlOpxt & OlOpxt & OlOpxt & OlOpxt & OlOpxt & OlOpxt & OlOpxt & OlOpxt \\
\hline As & 0 & 0 & 0 & 0 & 0 & 0 & 0 & 0 & 0 & 0 & 0 & 0 \\
\hline $\mathrm{Zn}$ & 0 & 0.07 & 0.013 & 0.008 & 0.012 & 0 & 0 & 0 & 0.068 & 0.096 & 0.061 & 0 \\
\hline $\mathrm{Ga}$ & 0 & 0 & 0 & 0 & 0 & 0 & 0 & 0 & 0 & 0 & 0 & 0 \\
\hline $\mathrm{Se}$ & 0 & 0 & 0.025 & 0.015 & 0.019 & 0.047 & 0 & 0 & 0.011 & 0.033 & 0.044 & 0 \\
\hline$S$ & 38.333 & 36.973 & 38.677 & 38.246 & 38.003 & 36.667 & 37.033 & 38.863 & 38.572 & 37.032 & 36.747 & 39.074 \\
\hline $\mathrm{Pb}$ & 0.096 & 0.172 & 0.151 & 0.216 & 0 & 0.153 & 0.135 & 0.209 & 0.033 & 0.098 & 0.174 & 0.187 \\
\hline $\mathrm{Bi}$ & 0 & 0 & 0.033 & 0 & 0 & 0.077 & 0 & 0 & 0 & 0.099 & 0.123 & 0.02 \\
\hline $\mathrm{Te}$ & 0.019 & 0.028 & 0 & 0.007 & 0.045 & 0 & 0.009 & 0 & 0 & 0.057 & 0 & 0 \\
\hline $\mathrm{Fe}$ & 58.424 & 57.896 & 58.683 & 59.066 & 58.894 & 60.629 & 60.369 & 58.647 & 58.64 & 60.68 & 61.313 & 59.012 \\
\hline Co & 0.033 & 0.029 & 0.074 & 0.038 & 0.049 & 0.067 & 0.062 & 0.035 & 0.075 & 0.064 & 0.083 & 0.067 \\
\hline $\mathrm{Cu}$ & 0.097 & 0.058 & 0.021 & 0 & 0.029 & 0.07 & 0.09 & 0.041 & 0.049 & 0 & 0.074 & 0.085 \\
\hline $\mathrm{Sb}$ & 0 & 0.117 & 0.147 & 0 & 0.046 & 0 & 0.049 & 0.177 & 0 & 0 & 0.141 & 0.083 \\
\hline $\mathrm{Ni}$ & 0.011 & 0.051 & 0.026 & 0.024 & 0.074 & 0 & 0.002 & 0.026 & 0.027 & 0 & 0.046 & 0.046 \\
\hline Mo & 0.162 & 0.062 & 0.038 & 0.014 & 0.083 & 0.049 & 0.061 & 0.11 & 0.113 & 0.025 & 0.122 & 0.094 \\
\hline $\mathrm{Au}$ & 0 & 0 & 0 & 0 & 0 & 0 & 0.004 & 0.011 & 0 & 0 & 0 & 0 \\
\hline $\mathrm{Ag}$ & 0 & 0.012 & 0.002 & 0.005 & 0 & 0.004 & 0 & 0.012 & 0.009 & 0.001 & 0 & 0 \\
\hline $\mathrm{Pd}$ & 0.009 & 0 & 0.011 & 0 & 0 & 0 & 0.002 & 0 & 0 & 0.012 & 0.004 & 0 \\
\hline $\mathrm{Pt}$ & 0 & 0 & 0 & 0 & 0 & 0 & 0 & 0 & 0 & 0 & 0 & 0.003 \\
\hline total & 99.791 & 98.983 & 100.038 & 100.582 & 100.471 & 99.845 & 97.816 & 98.131 & 97.597 & 98.197 & 98.932 & 98.671 \\
\hline Amostra & M-14_C1_po & -14_C1_po & 1-14_C2_pc & 1-14_C2_po & 14_C2_pc & 14_C2_pc & 14_C2_po & 14_C2_po & 14_C2_po & 4_C2_po & 4_C2_po & 4_C2_po 1 \\
\hline Prof. & 102.4 & 102.4 & 102.4 & 102.4 & 102.4 & 102.4 & 102.4 & 102.4 & 102.4 & 102.4 & 102.4 & 102.4 \\
\hline Rocha & OlOpxt & OlOpxt & OlOpxt & OlOpxt & OlOpxt & OlOpxt & OlOpxt & OlOpxt & OlOpxt & OlOpxt & OlOpxt & OlOpxt \\
\hline As & 0 & 0 & 0 & 0 & 0 & 0 & 0 & 0 & 0 & 0 & 0 & 0 \\
\hline $\mathrm{Zn}$ & 0.042 & 0.009 & 0.062 & 0 & 0.034 & 0.021 & 0 & 0.074 & 0 & 0.023 & 0 & 0 \\
\hline $\mathrm{Ga}$ & 0 & 0 & 0 & 0 & 0 & 0 & 0 & 0 & 0 & 0 & 0 & 0 \\
\hline $\mathrm{Se}$ & 0.045 & 0 & 0.01 & 0.023 & 0.013 & 0.013 & 0 & 0.013 & 0 & 0.027 & 0.007 & 0.002 \\
\hline S & 38.44 & 39.249 & 37.163 & 38.774 & 39.498 & 39.42 & 39.091 & 39.111 & 37.75 & 39.18 & 38.873 & 39.067 \\
\hline $\mathrm{Pb}$ & 0.108 & 0.129 & 0.121 & 0.185 & 0.257 & 0.219 & 0.227 & 0.135 & 0.086 & 0.265 & 0.072 & 0.072 \\
\hline $\mathrm{Bi}$ & 0 & 0 & 0 & 0 & 0.048 & 0 & 0.007 & 0 & 0 & 0 & 0 & 0 \\
\hline $\mathrm{Te}$ & 0.028 & 0 & 0.005 & 0 & 0.005 & 0.016 & 0 & 0 & 0.031 & 0 & 0 & 0 \\
\hline $\mathrm{Fe}$ & 59.302 & 59.025 & 60.535 & 58.761 & 58.132 & 58.766 & 59.093 & 58.839 & 60.539 & 58.957 & 57.637 & 58.713 \\
\hline Co & 0.091 & 0.046 & 0.064 & 0.074 & 0.056 & 0.036 & 0.024 & 0.035 & 0.061 & 0.059 & 0.097 & 0.034 \\
\hline $\mathrm{Cu}$ & 0.05 & 0.043 & 0.052 & 0.018 & 0.051 & 0 & 0.006 & 0.016 & 0.035 & 0.011 & 0.037 & 0.043 \\
\hline $\mathrm{Sb}$ & 0 & 0.033 & 0 & 0 & 0 & 0.074 & 0.194 & 0 & 0.034 & 0 & 0 & 0.016 \\
\hline $\mathrm{Ni}$ & 0.016 & 0.029 & 0.002 & 0.031 & 0.025 & 0.031 & 0.046 & 0.048 & 0 & 0.052 & 0.016 & 0 \\
\hline Mo & 0.035 & 0.047 & 0.069 & 0.093 & 0.062 & 0.065 & 0.059 & 0.045 & 0.145 & 0.036 & 0.069 & 0.04 \\
\hline $\mathrm{Au}$ & 0 & 0 & 0 & 0 & 0 & 0 & 0 & 0.008 & 0.025 & 0 & 0.01 & 0 \\
\hline $\mathrm{Ag}$ & 0.027 & 0.005 & 0 & 0 & 0 & 0.004 & 0.019 & 0.028 & 0.015 & 0 & 0.009 & 0 \\
\hline $\mathrm{Pd}$ & 0 & 0 & 0.015 & 0 & 0 & 0.014 & 0.026 & 0 & 0.02 & 0 & 0 & 0 \\
\hline $\mathrm{Pt}$ & 0 & 0 & 0 & 0 & 0 & 0 & 0 & 0 & 0.025 & 0 & 0 & 0 \\
\hline total & 98.184 & 98.615 & 98.098 & 97.959 & 98.181 & 98.679 & 98.792 & 98.352 & 98.766 & 98.61 & 96.827 & 97.987 \\
\hline Amostra & M-14_C2_po & -14_C2_po & 1M-14_C2_po & 1-14_C3_po & 14_C3_pc & 14_C3_pc & 14_C3_po & 4_C3_po & 4_C3_po & 4_C3_po & 4_C3_po & 4_C3_po 1 \\
\hline Prof. & $102 . \overline{4}$ & 102.4 & $102 . \overline{4}$ & $102 . \overline{4}$ & $102 . \overline{4}$ & 102.4 & 102.4 & 102.4 & 102.4 & 102.4 & 102.4 & 102.4 \\
\hline Rocha & OIOpxt & OIOpxt & OlOpxt & OlOpxt & OlOpxt & OlOpxt & OIOpxt & OlOpxt & OlOpxt & OIOpxt & OlOpxt & OlOpxt \\
\hline As & 0 & 0 & 0 & 0 & 0 & 0 & 0 & 0 & 0 & 0 & 0 & 0 \\
\hline $\mathrm{Zn}$ & 0 & 0.038 & 0 & 0 & 0 & 0 & 0.003 & 0.054 & 0 & 0 & 0 & 0 \\
\hline $\mathrm{Ga}$ & 0 & 0 & 0 & 0 & 0 & 0 & 0 & 0 & 0 & 0 & 0 & 0 \\
\hline Se & 0.035 & 0 & 0 & 0 & 0.032 & 0.071 & 0 & 0 & 0.001 & 0 & 0.001 & 0.011 \\
\hline s & 37.643 & 37.455 & 37.66 & 38.027 & 38.832 & 39.417 & 37.78 & 38.702 & 38.813 & 38.892 & 37.627 & 38.893 \\
\hline $\mathrm{Pb}$ & 0.143 & 0.122 & 0.175 & 0.114 & 0.154 & 0 & 0.029 & 0.176 & 0.203 & 0.219 & 0.085 & 0.137 \\
\hline $\mathrm{Bi}$ & 0 & 0.017 & 0 & 0 & 0 & 0.009 & 0 & 0.005 & 0 & 0 & 0 & 0 \\
\hline $\mathrm{Te}$ & 0 & 0.011 & 0.003 & 0 & 0 & 0 & 0 & 0 & 0.018 & 0.018 & 0 & 0 \\
\hline $\mathrm{Fe}$ & 60.555 & 61.064 & 60.255 & 58.644 & 58.943 & 58.791 & 59.451 & 58.772 & 58.551 & 58.06 & 60.605 & 58.813 \\
\hline Co & 0.021 & 0.064 & 0.052 & 0.063 & 0.018 & 0.062 & 0.062 & 0.061 & 0.028 & 0.051 & 0.04 & 0.077 \\
\hline $\mathrm{Cu}$ & 0.104 & 0.028 & 0.008 & 0.051 & 0.057 & 0.014 & 0 & 0.121 & 0.111 & 0.045 & 0.06 & 0.014 \\
\hline $\mathrm{Sb}$ & 0.08 & 0 & 0 & 0 & 0 & 0 & 0 & 0 & 0.015 & 0 & 0.035 & 0 \\
\hline $\mathrm{Ni}$ & 0 & 0.01 & 0 & 0.029 & 0.06 & 0.035 & 0 & 0.015 & 0.026 & 0.012 & 0.016 & 0.026 \\
\hline Mo & 0.072 & 0.066 & 0.063 & 0.088 & 0.097 & 0.119 & 0.06 & 0.083 & 0.098 & 0.08 & 0.101 & 0.047 \\
\hline $\mathrm{Au}$ & 0 & 0.002 & 0 & 0.014 & 0 & 0 & 0 & 0.029 & 0 & 0 & 0.005 & 0 \\
\hline $\mathrm{Ag}$ & 0 & 0 & 0.01 & 0 & 0.002 & 0.026 & 0 & 0.001 & 0.001 & 0 & 0 & 0 \\
\hline $\mathrm{Pd}$ & 0 & 0.005 & 0 & 0.003 & 0 & 0 & 0 & 0.02 & 0 & 0 & 0.011 & 0 \\
\hline $\mathrm{Pt}$ & 0 & 0 & 0 & 0 & 0 & 0 & 0 & 0 & 0.032 & 0 & 0 & 0 \\
\hline total & 98.653 & 98.882 & 98.226 & 97.033 & 98.195 & 98.544 & 97.385 & 98.039 & 97.897 & 97.377 & 98.586 & 98.018 \\
\hline
\end{tabular}




\begin{tabular}{|c|c|c|c|c|c|c|c|c|c|c|c|c|}
\hline \multirow{3}{*}{$\begin{array}{l}\text { Amostra } \\
\text { Prof. } \\
\text { Rocha }\end{array}$} & \multicolumn{12}{|c|}{ M-14_C3_po 1 M-13_C4_po 1M-13_C4_po1M-13_C4_po3M-06B_C1_po M-06B_C1_po M-06B_C1_po M-06B_C2_po M-06B_C3_po M-06B_C3_po M-06B_C3_po M-06B_C3_po } \\
\hline & $\overline{102.4}$ & 149.6 & 149.6 & 149.6 & 220.4 & 220.4 & 220.4 & 220.4 & 220.4 & 220.4 & 220.4 & 220.4 \\
\hline & OlOpxt & $\mathrm{Hzb}$ & $\mathrm{Hzb}$ & $\mathrm{Hzb}$ & Pxt & Pxt & Pxt & Pxt & Pxt & Pxt & Pxt & Pxt \\
\hline As & 0 & 0 & 0 & 0 & 0 & 0 & 0 & 0 & 0 & 0 & 0 & 0 \\
\hline $\mathrm{Zn}$ & 0.022 & 0 & 0.048 & 0 & 0.028 & 0 & 0.05 & 0.052 & 0 & 0.025 & 0.004 & 0.07 \\
\hline $\mathrm{Ga}$ & 0 & 0 & 0 & 0 & 0 & 0 & 0 & 0 & 0 & 0 & 0 & 0 \\
\hline Se & 0.034 & 0 & 0 & 0.033 & 0.027 & 0.029 & 0 & 0 & 0.033 & 0 & 0.049 & 0 \\
\hline$S$ & 39.579 & 36.845 & 36.892 & 36.843 & 38.732 & 39.319 & 38.834 & 40.52 & 39.391 & 39.333 & 39.381 & 39.771 \\
\hline $\mathrm{Pb}$ & 0 & 0.149 & 0.133 & 0.175 & 0.214 & 0.2 & 0.176 & 0.12 & 0.188 & 0.081 & 0.049 & 0.164 \\
\hline $\mathrm{Bi}$ & 0 & 0 & 0 & 0.01 & 0.018 & 0 & 0 & 0.031 & 0.023 & 0 & 0.11 & 0.027 \\
\hline $\mathrm{Te}$ & 0.03 & 0 & 0 & 0 & 0.02 & 0.001 & 0.002 & 0 & 0 & 0 & 0.029 & 0 \\
\hline $\mathrm{Fe}$ & 58.133 & 61.02 & 61.436 & 61.194 & 58.762 & 59.018 & 58.664 & 57.915 & 58.531 & 58.107 & 57.703 & 57.92 \\
\hline Co & 0.045 & 0.061 & 0.048 & 0.088 & 0.062 & 0.063 & 0.062 & 0.065 & 0.055 & 0.061 & 0.061 & 0.051 \\
\hline $\mathrm{Cu}$ & 0 & 0.106 & 0.165 & 0.144 & 0 & 0.056 & 0.014 & 0.048 & 0 & 0 & 0.044 & 0.003 \\
\hline $\mathrm{Sb}$ & 0 & 0 & 0 & 0 & 0 & 0 & 0.012 & 0 & 0.113 & 0 & 0 & 0 \\
\hline $\mathrm{Ni}$ & 0 & 0.026 & 0 & 0 & 0.027 & 0.041 & 0.057 & 0.03 & 0.043 & 0.023 & 0.018 & 0.037 \\
\hline Mo & 0.089 & 0.165 & 0.038 & 0.111 & 0.109 & 0.106 & 0 & 0.03 & 0.047 & 0.029 & 0.057 & 0.001 \\
\hline $\mathrm{Au}$ & 0 & 0 & 0.008 & 0 & 0 & 0 & 0 & 0 & 0.037 & 0 & 0 & 0.051 \\
\hline $\mathrm{Ag}$ & 0.006 & 0 & 0.014 & 0 & 0 & 0 & 0.007 & 0 & 0.016 & 0 & 0.004 & 0 \\
\hline $\mathrm{Pd}$ & 0 & 0.018 & 0 & 0 & 0.001 & 0 & 0 & 0.01 & 0 & 0 & 0.004 & 0 \\
\hline $\mathrm{Pt}$ & 0 & 0 & 0 & 0 & 0 & 0 & 0 & 0 & 0 & 0 & 0 & 0 \\
\hline total & 97.938 & 98.39 & 98.782 & 98.598 & 98 & 98.833 & 97.878 & 98.821 & 98.477 & 97.659 & 97.513 & 98.095 \\
\hline Amostra & \multicolumn{12}{|c|}{ M-06B_C3_po M-06B_C3_po M-06B_C3_po M-06B_C4_po M-06B_C4_po M-06B_C5_po M-06B_C5_po M-06B_C5_po M-06B_C5_po M-06B_C5_po M-06B_C5_po M-06A_C1_po } \\
\hline Prof. & 220.4 & 220.4 & 220.4 & 220.4 & 220.4 & 220.4 & 220.4 & 220.4 & 220.4 & 220.4 & 220.4 & 220.2 \\
\hline Rocha & Pxt & Pxt & Pxt & Pxt & Pxt & Pxt & Pxt & Pxt & Pxt & Pxt & Pxt & Xnt \\
\hline As & 0 & 0 & 0 & 0 & 0 & 0 & 0 & 0 & 0 & 0 & 0 & 0 \\
\hline $\mathrm{Zn}$ & 0.054 & 0.031 & 0.021 & 0.044 & 0.058 & 0 & 0.035 & 0.044 & 0 & 0 & 0 & 0 \\
\hline $\mathrm{Ga}$ & 0 & 0 & 0 & 0 & 0 & 0 & 0 & 0 & 0 & 0 & 0 & 0 \\
\hline Se & 0 & 0 & 0 & 0.039 & 0 & 0.028 & 0.057 & 0 & 0.045 & 0.012 & 0.036 & 0 \\
\hline $\mathrm{s}$ & 39.153 & 38.65 & 38.994 & 39.381 & 39.557 & 39.443 & 39.91 & 38.917 & 38.72 & 39.008 & 38.773 & 38.696 \\
\hline $\mathrm{Pb}$ & 0.173 & 0.096 & 0.06 & 0.282 & 0.096 & 0.232 & 0.277 & 0.16 & 0.172 & 0.162 & 0.174 & 0.209 \\
\hline $\mathrm{Bi}$ & 0 & 0 & 0 & 0 & 0 & 0 & 0.007 & 0 & 0.111 & 0.041 & 0 & 0 \\
\hline $\mathrm{Te}$ & 0 & 0 & 0 & 0 & 0 & 0 & 0.005 & 0 & 0 & 0 & 0.014 & 0 \\
\hline $\mathrm{Fe}$ & 58.28 & 58.707 & 59.033 & 57.905 & 57.733 & 58.325 & 57.278 & 58.409 & 58.574 & 59.106 & 59.133 & 58.711 \\
\hline Co & 0.013 & 0.046 & 0.07 & 0.056 & 0.086 & 0.077 & 0.076 & 0.069 & 0.048 & 0.013 & 0.061 & 0.049 \\
\hline $\mathrm{Cu}$ & 0.016 & 0 & 0 & 0.039 & 0.039 & 0.013 & 0.016 & 0.015 & 0 & 0.008 & 0 & 0.028 \\
\hline $\mathrm{Sb}$ & 0.057 & 0.047 & 0 & 0 & 0.102 & 0.07 & 0 & 0 & 0 & 0 & 0 & 0.016 \\
\hline $\mathrm{Ni}$ & 0.034 & 0.044 & 0.042 & 0.04 & 0 & 0.072 & 0.025 & 0.003 & 0.068 & 0.005 & 0.034 & 0 \\
\hline Mo & 0.074 & 0.138 & 0.157 & 0.083 & 0.092 & 0.061 & 0.09 & 0.064 & 0.006 & 0.041 & 0.095 & 0.052 \\
\hline $\mathrm{Au}$ & 0 & 0.015 & 0 & 0 & 0 & 0 & 0.038 & 0 & 0 & 0 & 0 & 0 \\
\hline $\mathrm{Ag}$ & 0.007 & 0 & 0 & 0 & 0 & 0.005 & 0 & 0 & 0 & 0 & 0.001 & 0 \\
\hline $\mathrm{Pd}$ & 0.004 & 0 & 0 & 0 & 0.007 & 0.003 & 0 & 0 & 0 & 0 & 0 & 0 \\
\hline $\mathrm{Pt}$ & 0 & 0 & 0 & 0 & 0.011 & 0 & 0 & 0 & 0.024 & 0 & 0.027 & 0 \\
\hline total & 97.865 & 97.774 & 98.377 & 97.869 & 97.781 & 98.329 & 97.814 & 97.681 & 97.768 & 98.396 & 98.348 & 97.761 \\
\hline Amostra & \multicolumn{12}{|c|}{ M-06A_C1_po M-06A_C1_po M-06A_C1_po M-06A_C1_po M-06A_C1_poM-06A_C1_po M-06A_C1_po M-06A_C1_po M-06A_C1_po M-06A_C1_po M-06A_C1_po M-06A_C1_po } \\
\hline Prof. & 220.2 & 220.2 & 220.2 & 220.2 & 220.2 & 220.2 & 220.2 & 220.2 & 220.2 & 220.2 & 220.2 & 220.2 \\
\hline Rocha & Xnt & Xnt & Xnt & Xnt & Xnt & Xnt & Xnt & Xnt & Xnt & Xnt & Xnt & Xnt \\
\hline As & 0 & 0 & 0 & 0 & 0 & 0 & 0 & 0 & 0 & 0 & 0 & 0 \\
\hline $\mathrm{Zn}$ & 0 & 0 & 0 & 0 & 0.01 & 0.009 & 0.111 & 0 & 0.061 & 0 & 0.016 & 0.026 \\
\hline $\mathrm{Ga}$ & 0 & 0 & 0 & 0 & 0 & 0 & 0 & 0 & 0 & 0 & 0 & 0 \\
\hline $\mathrm{Se}$ & 0 & 0.016 & 0.016 & 0 & 0 & 0 & 0 & 0.034 & 0.005 & 0.003 & 0.02 & 0 \\
\hline$S$ & 38.965 & 38.494 & 39.088 & 39.181 & 39.224 & 38.816 & 38.899 & 39.46 & 39.546 & 39.206 & 38.898 & 39.106 \\
\hline $\mathrm{Pb}$ & 0.082 & 0.195 & 0.062 & 0.149 & 0.156 & 0.163 & 0.137 & 0.145 & 0.116 & 0.127 & 0.121 & 0.124 \\
\hline $\mathrm{Bi}$ & 0 & 0 & 0 & 0.124 & 0 & 0 & 0 & 0.054 & 0 & 0 & 0 & 0 \\
\hline $\mathrm{Te}$ & 0 & 0 & 0 & 0 & 0.057 & 0 & 0 & 0.004 & 0 & 0.016 & 0.033 & 0 \\
\hline $\mathrm{Fe}$ & 58.904 & 57.269 & 58.792 & 58.664 & 58.538 & 58.527 & 58.614 & 58.545 & 58.343 & 58.376 & 57.845 & 58.697 \\
\hline Co & 0.056 & 0.013 & 0.046 & 0.074 & 0.065 & 0.052 & 0.061 & 0.056 & 0.084 & 0.063 & 0.075 & 0.04 \\
\hline $\mathrm{Cu}$ & 0 & 0 & 0 & 0 & 0.007 & 0.002 & 0.026 & 0 & 0 & 0.028 & 0 & 0.013 \\
\hline $\mathrm{Sb}$ & 0 & 0.008 & 0 & 0.009 & 0.023 & 0.112 & 0.119 & 0 & 0.177 & 0 & 0.078 & 0 \\
\hline $\mathrm{Ni}$ & 0.021 & 0.025 & 0.066 & 0.047 & 0.069 & 0.015 & 0.055 & 0.031 & 0 & 0.021 & 0.075 & 0.031 \\
\hline Mo & 0.049 & 0.118 & 0.136 & 0.061 & 0.133 & 0.097 & 0.077 & 0.056 & 0.116 & 0.076 & 0.144 & 0.079 \\
\hline $\mathrm{Au}$ & 0 & 0 & 0 & 0 & 0 & 0 & 0 & 0 & 0 & 0 & 0 & 0.006 \\
\hline $\mathrm{Ag}$ & 0 & 0.003 & 0.02 & 0.018 & 0 & 0 & 0.003 & 0.009 & 0.008 & 0 & 0.011 & 0 \\
\hline $\mathrm{Pd}$ & 0.016 & 0 & 0.011 & 0 & 0 & 0 & 0 & 0 & 0.006 & 0 & 0 & 0.004 \\
\hline $\mathrm{Pt}$ & 0 & 0 & 0 & 0 & 0.014 & 0 & 0 & 0 & 0 & 0 & 0 & 0 \\
\hline total & 98.093 & 96.141 & 98.237 & 98.327 & 98.296 & 97.793 & 98.102 & 98.394 & 98.462 & 97.916 & 97.316 & 98.126 \\
\hline
\end{tabular}




\begin{tabular}{|c|c|c|c|c|c|c|c|c|c|c|c|c|}
\hline \multirow{3}{*}{$\begin{array}{l}\text { Amostra } \\
\text { Prof. } \\
\text { Rocha }\end{array}$} & \multicolumn{3}{|c|}{ h-06A_C1_po \&1-06A_C1_po \&1-06A_C1_po } & \multicolumn{9}{|c|}{ 2M-06A_C2_po M-06A_C3_po M-06A_C3_po M-06A_C3_po M-06A_C3_po M-06A_C3_po M-06A_C3_po M-06A_C3_po M-06A_C4_po } \\
\hline & 220.2 & 220.2 & 220.2 & 220.2 & 220.2 & 220.2 & 220.2 & 220.2 & 220.2 & 220.2 & 220.2 & 220.2 \\
\hline & Xnt & Xnt & Xnt & Xnt & Xnt & Xnt & Xnt & Xnt & Xnt & Xnt & Xnt & Xnt \\
\hline As & 0 & 0 & 0 & 0 & 0 & 0 & 0 & 0 & 0 & 0 & 0 & 0 \\
\hline $\mathrm{Zn}$ & 0 & 0 & 0.047 & 0 & 0 & 0 & 0 & 0 & 0.103 & 0 & 0 & 0.011 \\
\hline $\mathrm{Ga}$ & 0 & 0 & 0 & 0 & 0 & 0 & 0 & 0 & 0 & 0 & 0 & 0 \\
\hline $\mathrm{Se}$ & 0.036 & 0 & 0.018 & 0.049 & 0.037 & 0.016 & 0 & 0 & 0.021 & 0 & 0 & 0 \\
\hline$S$ & 38.872 & 39.612 & 39.254 & 39.505 & 38.538 & 38.806 & 39.258 & 39.321 & 39.782 & 38.917 & 38.906 & 39.758 \\
\hline $\mathrm{Pb}$ & 0.111 & 0.142 & 0.115 & 0.205 & 0.148 & 0.051 & 0.225 & 0.091 & 0.17 & 0.118 & 0.157 & 0.108 \\
\hline $\mathrm{Bi}$ & 0.007 & 0 & 0.058 & 0 & 0 & 0 & 0 & 0.003 & 0.051 & 0.049 & 0 & 0 \\
\hline $\mathrm{Te}$ & 0 & 0 & 0.047 & 0.055 & 0.046 & 0 & 0.015 & 0.041 & 0 & 0.024 & 0 & 0 \\
\hline $\mathrm{Fe}$ & 58.591 & 58.8 & 58.526 & 58.741 & 58.346 & 58.493 & 59.032 & 58.482 & 57.493 & 58.426 & 58.114 & 57.884 \\
\hline Co & 0.058 & 0.031 & 0.068 & 0.012 & 0.083 & 0.052 & 0.084 & 0.087 & 0.062 & 0.057 & 0.074 & 0.038 \\
\hline $\mathrm{Cu}$ & 0 & 0 & 0 & 0.047 & 0 & 0.12 & 0.024 & 0.07 & 0.022 & 0.017 & 0 & 0 \\
\hline $\mathrm{Sb}$ & 0 & 0 & 0.009 & 0 & 0.002 & 0.104 & 0 & 0 & 0.075 & 0 & 0.13 & 0 \\
\hline $\mathrm{Ni}$ & 0.014 & 0.037 & 0.077 & 0.036 & 0.029 & 0.067 & 0.001 & 0.095 & 0.006 & 0.033 & 0.021 & 0.043 \\
\hline Mo & 0.077 & 0.099 & 0.109 & 0.087 & 0.028 & 0.036 & 0.118 & 0.085 & 0.095 & 0.057 & 0.101 & 0.101 \\
\hline $\mathrm{Au}$ & 0 & 0 & 0.017 & 0 & 0 & 0 & 0 & 0 & 0 & 0.01 & 0 & 0 \\
\hline $\mathrm{Ag}$ & 0 & 0.008 & 0.002 & 0 & 0.016 & 0 & 0.015 & 0.002 & 0.001 & 0 & 0 & 0.006 \\
\hline $\mathrm{Pd}$ & 0 & 0.001 & 0.003 & 0 & 0 & 0.011 & 0.002 & 0.002 & 0 & 0.02 & 0 & 0.009 \\
\hline $\mathrm{Pt}$ & 0 & 0 & 0 & 0 & 0 & 0 & 0 & 0 & 0 & 0 & 0 & 0 \\
\hline total & 97.766 & 98.73 & 98.35 & 98.737 & 97.273 & 97.756 & 98.774 & 98.279 & 97.881 & 97.728 & 97.503 & 97.958 \\
\hline Amostra & M-06A_C4_p & 6A_C4_p & 6A_C4_p & 6A_C4_p & 6A_C4_p & A_C4_po & A_C4_po & A_C4_po & A_C4_po & A_C4_po & A_C4_po & \\
\hline Prof. & 220.2 & 220.2 & 220.2 & 220.2 & 220.2 & 220.2 & $220 . \overline{2}$ & 220.2 & 220.2 & 220.2 & 220.2 & \\
\hline Rocha & Xnt & Xnt & Xnt & Xnt & Xnt & Xnt & Xnt & Xnt & Xnt & Xnt & Xnt & \\
\hline As & 0 & 0 & 0 & 0.001 & 0 & 0 & 0 & 0 & 0 & 0 & 0 & \\
\hline $\mathrm{Zn}$ & 0 & 0 & 0 & 0.035 & 0.037 & 0 & 0.02 & 0 & 0 & 0 & 0.063 & \\
\hline $\mathrm{Ga}$ & 0 & 0 & 0 & 0 & 0 & 0 & 0 & 0 & 0 & 0 & 0 & \\
\hline $\mathrm{Se}$ & 0.03 & 0 & 0.056 & 0.026 & 0 & 0.042 & 0.021 & 0.007 & 0 & 0 & 0 & \\
\hline$S$ & 39.256 & 39.914 & 39.791 & 39.094 & 38.441 & 39.375 & 39.964 & 39.917 & 39.131 & 38.928 & 38.986 & \\
\hline $\mathrm{Pb}$ & 0.055 & 0.113 & 0.18 & 0.217 & 0.149 & 0.177 & 0.13 & 0.157 & 0.147 & 0.128 & 0.125 & \\
\hline $\mathrm{Bi}$ & 0 & 0 & 0 & 0 & 0 & 0 & 0 & 0 & 0 & 0 & 0 & \\
\hline $\mathrm{Te}$ & 0.007 & 0.006 & 0 & 0 & 0.017 & 0 & 0.019 & 0 & 0 & 0.01 & 0 & \\
\hline $\mathrm{Fe}$ & 58.343 & 57.641 & 58.095 & 58.989 & 59.002 & 58.337 & 57.992 & 58.822 & 59.038 & 58.283 & 58.514 & \\
\hline Co & 0.034 & 0.053 & 0.038 & 0.024 & 0.08 & 0.067 & 0.045 & 0.046 & 0.09 & 0.046 & 0.109 & \\
\hline $\mathrm{Cu}$ & 0.016 & 0.015 & 0.063 & 0 & 0 & 0.011 & 0 & 0.05 & 0 & 0.011 & 0 & \\
\hline $\mathrm{Sb}$ & 0 & 0 & 0 & 0 & 0.038 & 0 & 0.048 & 0 & 0.032 & 0.025 & 0 & \\
\hline $\mathrm{Ni}$ & 0.047 & 0.004 & 0.027 & 0.041 & 0.037 & 0.034 & 0.033 & 0.02 & 0.043 & 0.079 & 0.059 & \\
\hline Mo & 0.006 & 0.059 & 0.057 & 0.057 & 0.127 & 0.092 & 0.053 & 0.035 & 0.036 & 0.034 & 0.092 & \\
\hline $\mathrm{Au}$ & 0 & 0 & 0 & 0.039 & 0.036 & 0 & 0 & 0 & 0 & 0 & 0 & \\
\hline $\mathrm{Ag}$ & 0.024 & 0.021 & 0 & 0.024 & 0 & 0 & 0 & 0 & 0 & 0 & 0.015 & \\
\hline $\mathrm{Pd}$ & 0 & 0.005 & 0 & 0.002 & 0.002 & 0 & 0 & 0.012 & 0.036 & 0.01 & 0 & \\
\hline $\mathrm{Pt}$ & 0 & 0 & 0 & 0 & 0 & 0 & 0 & 0 & 0 & 0 & 0 & \\
\hline total & 97.818 & 97.831 & 98.307 & 98.549 & 97.966 & 98.135 & 98.325 & 99.066 & 98.553 & 97.554 & 97.963 & \\
\hline
\end{tabular}




\section{CALCOPIRITA}

\begin{tabular}{|c|c|c|c|c|c|c|c|c|c|c|c|}
\hline \multirow{3}{*}{$\begin{array}{l}\text { Amostra } \\
\text { Prof. } \\
\text { Rocha }\end{array}$} & \multicolumn{11}{|c|}{ 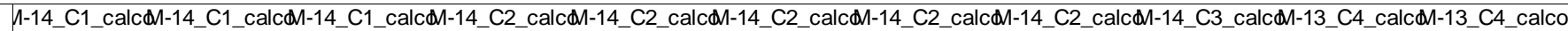 } \\
\hline & 102.4 & 102.4 & 102.4 & 102.4 & $10 \overline{2} .4$ & 102.4 & 102.4 & 102.4 & 102.4 & $1 \overline{49} .6$ & 149.6 \\
\hline & OlOpxt & OlOpxt & OlOpxt & OlOpxt & OlOpxt & OIOpxt & OlOpxt & OIOpxt & OlOpxt & $\mathrm{Hzb}$ & $\mathrm{Hzb}$ \\
\hline As & 0 & 0 & 0 & 0 & 0 & 0 & 0 & 0 & 0 & 0 & 0 \\
\hline $\mathrm{Zn}$ & 0 & 0.04 & 0 & 0.085 & 0.11 & 0.086 & 0 & 0 & 0 & 0.132 & 0.178 \\
\hline Ga & 0 & 0 & 0 & 0 & 0 & 0 & 0 & 0 & 0 & 0 & 0 \\
\hline Se & 0 & 0.008 & 0.025 & 0 & 0.028 & 0 & 0.025 & 0.012 & 0.002 & 0.031 & 0 \\
\hline $\mathrm{S}$ & 33.705 & 34.625 & 36.574 & 34.9 & 34.625 & 34.655 & 37.765 & 34.797 & 37.894 & 34.231 & 34.763 \\
\hline $\mathrm{Pb}$ & 0.067 & 0.006 & 0.234 & 0.075 & 0.11 & 0.139 & 0.111 & 0.085 & 0.148 & 0.176 & 0.043 \\
\hline $\mathrm{Bi}$ & 0 & 0.071 & 0 & 0.004 & 0 & 0 & 0 & 0 & 0.038 & 0.014 & 0 \\
\hline $\mathrm{Te}$ & 0 & 0.041 & 0 & 0.039 & 0 & 0.008 & 0.015 & 0 & 0 & 0.01 & 0 \\
\hline $\mathrm{Fe}$ & 30.346 & 29.802 & 62.248 & 30.475 & 30.165 & 30.111 & 62.375 & 30.91 & 60.172 & 30.166 & 30.24 \\
\hline Co & 0.008 & 0.055 & 0.074 & 0.041 & 0.019 & 0.034 & 0.072 & 0.026 & 0.041 & 0.035 & 0 \\
\hline $\mathrm{Cu}$ & 34.542 & 34.607 & 0.083 & 34.805 & 34.875 & 35.042 & 0.05 & 34.837 & 0.048 & 34.385 & 34.409 \\
\hline $\mathrm{Sb}$ & 0 & 0.038 & 0 & 0.056 & 0.023 & 0 & 0.008 & 0 & 0 & 0 & 0 \\
\hline $\mathrm{Ni}$ & 0.002 & 0.003 & 0 & 0 & 0 & 0.012 & 0 & 0 & 0.035 & 0 & 0 \\
\hline Mo & 0.017 & 0.009 & 0.081 & 0.081 & 0.078 & 0.024 & 0.038 & 0.016 & 0.054 & 0.049 & 0.013 \\
\hline $\mathrm{Au}$ & 0 & 0 & 0 & 0 & 0 & 0 & 0 & 0.003 & 0 & 0 & 0 \\
\hline $\mathrm{Ag}$ & 0.019 & 0.02 & 0.025 & 0.022 & 0 & 0.018 & 0.015 & 0.006 & 0 & 0.021 & 0 \\
\hline $\mathrm{Pd}$ & 0.005 & 0 & 0 & 0 & 0.01 & 0.019 & 0.009 & 0.009 & 0.007 & 0 & 0 \\
\hline $\mathrm{Pt}$ & 0 & 0 & 0.009 & 0 & 0 & 0 & 0 & 0 & 0 & 0 & 0 \\
\hline total & 98.711 & 99.325 & 99.353 & 100.583 & 100.043 & 100.148 & 100.483 & 100.701 & 98.439 & 99.25 & 99.646 \\
\hline Amostra & \multicolumn{11}{|c|}{-06A_C2_calc -06A_C2_calc -06A_C2_calc -06A_C3_calc -06A_C4_calc -06A_C4_calc -06B_C3_calc-06B_C5_calc -06B_C5_calc-06B_C5_calc-06A_C4_calco } \\
\hline Prof. & $220 . \overline{2}$ & 220.2 & 220.2 & 220.2 & 220.2 & 220.2 & 220.4 & 220.4 & 220.4 & 220.4 & 220.4 \\
\hline Rocha & Xnt & Xnt & Xnt & Xnt & Xnt & Xnt & Pxt & Pxt & Pxt & Pxt & Pxt \\
\hline As & 0 & 0 & 0 & 0 & 0 & 0 & 0 & 0 & 0 & 0 & 0 \\
\hline $\mathrm{Zn}$ & 0.114 & 0.114 & 0 & 0.014 & 0.031 & 0.128 & 0 & 0 & 0.098 & 0 & 0.034 \\
\hline $\mathrm{Ga}$ & 0 & 0 & 0 & 0 & 0 & 0 & 0 & 0 & 0 & 0 & 0 \\
\hline $\mathrm{Se}$ & 0.064 & 0.034 & 0.036 & 0 & 0.088 & 0.034 & 0 & 0 & 0 & 0.045 & 0 \\
\hline S & 34.808 & 34.617 & 34.673 & 34.88 & 34.813 & 34.98 & 34.753 & 33.996 & 34.865 & 34.944 & 34.588 \\
\hline $\mathrm{Pb}$ & 0.089 & 0.123 & 0.133 & 0.132 & 0.238 & 0.136 & 0.13 & 0.161 & 0.107 & 0.126 & 0.104 \\
\hline $\mathrm{Bi}$ & 0 & 0 & 0 & 0 & 0 & 0 & 0.011 & 0.036 & 0 & 0.077 & 0 \\
\hline $\mathrm{Te}$ & 0 & 0 & 0.008 & 0.029 & 0 & 0 & 0.012 & 0 & 0.015 & 0 & 0 \\
\hline $\mathrm{Fe}$ & 30.441 & 30.315 & 30.268 & 30.432 & 30.752 & 30.365 & 30.804 & 30.402 & 29.632 & 30.15 & 29.122 \\
\hline Co & 0.01 & 0.043 & 0 & 0.047 & 0.043 & 0.03 & 0.017 & 0 & 0.023 & 0.026 & 0.046 \\
\hline $\mathrm{Cu}$ & 34.582 & 34.757 & 34.71 & 34.351 & 34.918 & 34.706 & 34.152 & 34.707 & 35.072 & 34.994 & 33.998 \\
\hline $\mathrm{Sb}$ & 0.07 & 0.089 & 0 & 0.178 & 0 & 0 & 0 & 0 & 0.055 & 0.057 & 0 \\
\hline $\mathrm{Ni}$ & 0.015 & 0 & 0 & 0.037 & 0 & 0.026 & 0.012 & 0.001 & 0 & 0 & 0 \\
\hline Mo & 0.104 & 0.006 & 0.009 & 0.092 & 0.081 & 0.085 & 0.048 & 0.124 & 0.034 & 0.111 & 0.045 \\
\hline $\mathrm{Au}$ & 0 & 0 & 0 & 0.004 & 0 & 0 & 0 & 0 & 0 & 0 & 0 \\
\hline $\mathrm{Ag}$ & 0.005 & 0 & 0.017 & 0 & 0.012 & 0 & 0 & 0.011 & 0.019 & 0.005 & 0.027 \\
\hline $\mathrm{Pd}$ & 0.02 & 0.01 & 0.012 & 0 & 0.006 & 0.005 & 0.022 & 0 & 0.02 & 0 & 0 \\
\hline $\mathrm{Pt}$ & 0 & 0 & 0 & 0 & 0 & 0 & 0 & 0 & 0 & 0 & 0 \\
\hline total & 100.322 & 100.108 & 99.866 & 100.196 & 100.982 & 100.495 & 99.961 & 99.438 & 99.94 & 100.535 & 97.964 \\
\hline
\end{tabular}




\section{PIRITA}

\begin{tabular}{|c|ccccccccc|}
\hline Amostra & M-06B_C5_pyM-06B_C5_py & M-06B_C5_py & M-06B_C4_py & M-06B_C4_py & M-06B_C4_py M-06B_C4_py M-06A_C2_py \\
Prof. & 220.4 & 220.4 & 220.4 & 220.4 & 220.4 & 220.4 & 220.4 & 220.2 \\
Rocha & Pxt & Pxt & Pxt & Pxt & Pxt & Pxt & Pxt & Xnt \\
\hline As & 0 & 0 & 0 & 0 & 0 & 0 & 0 & 0 \\
$\mathrm{Zn}$ & 0 & 0 & 0 & 0.021 & 0 & 0.061 & 0.033 & 0 \\
$\mathrm{Ga}$ & 0 & 0 & 0 & 0 & 0 & 0 & 0 & 0 \\
$\mathrm{Se}$ & 0.046 & 0.001 & 0.022 & 0 & 0 & 0.01 & 0.01 & 0.016 \\
$\mathrm{~S}$ & 53.143 & 53.272 & 53.111 & 53.461 & 53.44 & 53.128 & 53.774 & 52.72 \\
$\mathrm{~Pb}$ & 0.107 & 0.143 & 0.202 & 0.242 & 0.204 & 0.12 & 0.229 & 0.184 \\
$\mathrm{Bi}$ & 0 & 0 & 0 & 0 & 0 & 0 & 0 & 0 \\
$\mathrm{Te}$ & 0.006 & 0 & 0.004 & 0.01 & 0 & 0.015 & 0.028 & 0.031 \\
$\mathrm{Fe}$ & 46.292 & 45.182 & 46.454 & 46.39 & 46.557 & 43.695 & 46.961 & 42.248 \\
$\mathrm{Co}$ & 0.044 & 0.228 & 0.056 & 0.069 & 0.034 & 2.608 & 0.017 & 3.595 \\
$\mathrm{Cu}$ & 0.001 & 0 & 0.018 & 0.065 & 0.052 & 0.043 & 0.067 & 0.221 \\
$\mathrm{Sb}$ & 0 & 0 & 0 & 0.166 & 0.054 & 0 & 0.117 & 0.051 \\
$\mathrm{Ni}$ & 0.025 & 0.122 & 0.031 & 0.003 & 0.004 & 0.009 & 0 & 0.024 \\
$\mathrm{Mo}$ & 0.119 & 0.022 & 0.131 & 0.145 & 0.124 & 0.129 & 0.126 & 0.077 \\
$\mathrm{Au}$ & 0 & 0.003 & 0 & 0 & 0 & 0 & 0 & 0 \\
$\mathrm{Ag}$ & 0.008 & 0 & 0.001 & 0.01 & 0 & 0.027 & 0.001 & 0 \\
$\mathrm{Pd}$ & 0 & 0.01 & 0.008 & 0 & 0.002 & 0 & 0.006 & 0 \\
$\mathrm{Pt}$ & 0 & 0 & 0 & 0 & 0 & 0 & 0 & 0 \\
$\mathrm{Ttal}$ & 99.791 & 98.983 & 100.038 & 100.582 & 100.471 & 99.845 & 101.369 & 99.167 \\
\hline
\end{tabular}

